\title{
DOES SCENIC MAKE CENTS?
}

\author{
A Professional Project \\ presented to \\ the Faculty of California Polytechnic State University, \\ San Luis Obispo
}

In Partial Fulfillment

of the Requirements for the Degree

Master of City and Regional Planning

by

Sara Sanders

March 2015 
(C) 2015

Sara Sanders

ALL RIGHTS RESERVED 


\section{COMMITTEE MEMBERSHIP}

TITLE:

Does Scenic Make Cents?

AUTHOR:

Sara Sanders

DATE SUBMITTED:

March 2015

COMMITTEE CHAIR: $\quad$ Chris Clark JD

Lecturer for the City \& Regional Planning Department

COMMITTEE MEMBER: Scott Eades

Lecturer for the Civil Engineering Department

COMMITTEE MEMBER: Richard Murphy

Programming Director at the San Luis Obispo Council of Governments 


\section{ABSTRACT \\ Does Scenic Make Cents? \\ Sara Sanders}

The stretch of California Route One (Highway 1) from the City of San Luis Obispo reaching north to the Monterey County line is one of the most scenic drives in the United States. This stretch of highway is a destination in its own right; so much so, the San Luis Obispo North Coast Scenic Byway is federally designated as an AllAmerican Road, the highest scenic designation of any road or highway in the nation. There has been a history for funding the preservation and enhancement of these roads; however, it was removed in 2012. Even with the lack of current funding opportunities, the San Luis Obispo Council of Governments (SLOCOG) continues to recognize the importance of the corridor in attracting valuable tourism revenue thus commissioning this update and economic analysis. Through the economic analysis it was found that visitor spending in the byway region increased by $23 \%$ from over $\$ 500$ million in 2006 to almost $\$ 656$ million in 2012. In 2012, visitor spending related associated with scenic recognition and enhancement projects along the corridor was about $\$ 217,000$ in direct revenue. As a result of research, outreach, and data analysis, this project did find that being scenic does make "cents."

Keywords: San Luis Obispo North Coast Scenic Byway, All-American Roads, Scenic Byways, Economic Impacts 


\section{ACKNOWLEDGMENTS}

I would like to recognize Chris Clark for his guidance and being there to offer comic relief. I commend the work you do and I am honored that you always made time for a question or to tell a funny story. Keep it up, there are students that look forward to what you have to say and appreciate it!

I would like to thank SLOCOG Staff, Committees, and Board for their continued encouragement. I started as a Rideshare intern a month after moving across country in 2012. After two internships and this project, I became a full-time employee. I have learned so much from the people I have worked with especially, Geiska Velasquez. I did not think I could manage this entire project but you knew. Thank you for believing in me and for all the confidence you have instilled.

Lastly, I would like to thank my remarkable family (Mom, Dad, Robert) and fiancé, Jimmy, for being there. Through all the finals, crazy schedules, and interesting experiences, I know I can count on all of you no matter the time, place, or circumstance. Mom you are the most intelligent, caring, and generous woman I will ever know. You keep me in check. Thank you for being my sounding board and always having the best advice. Dad, I grew up wanting to be just like you and I am still trying. Thank you for your kindness, drive, and passion. You are a leader and inspire me to constantly learn and challenge myself. Robert, you taught me how to share, how to take responsibility, and you continue to help me work on my patience. I know you will do great things and you make me proud to be your sister. Jimmy you are my best friend; I could not have made it without you. You bring Michigan to California and I am extremely lucky that I have you in my life. I am a better person with you and I cannot imagine a day without you. I am excited to see what the future has in store for us. All of you mean more to me than you will ever know and I love you. 


\section{TABLE OF CONTENTS}

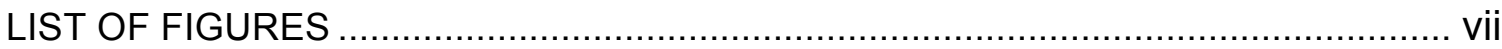

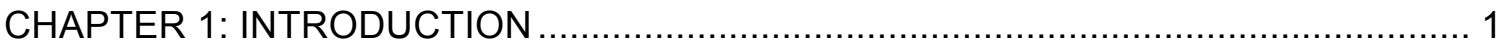

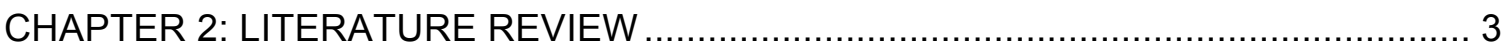

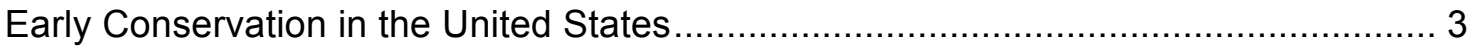

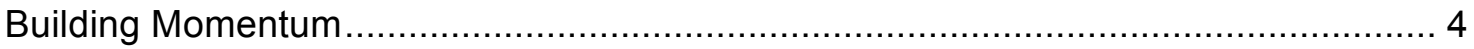

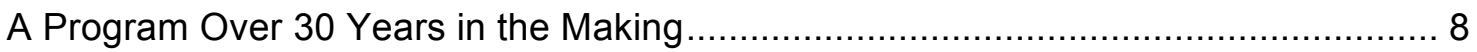

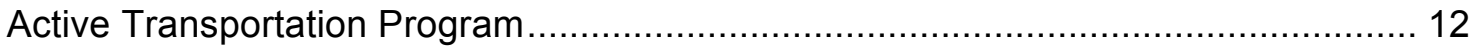

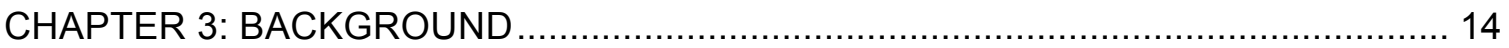

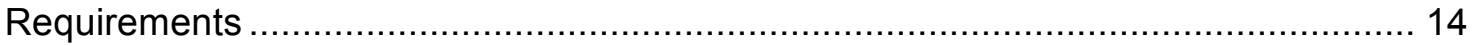

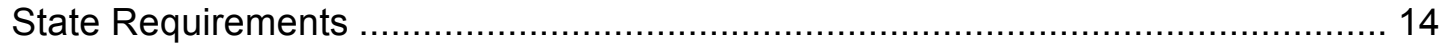

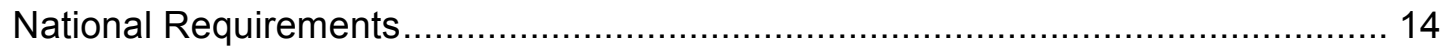

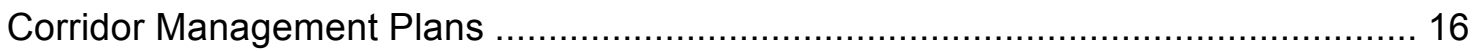

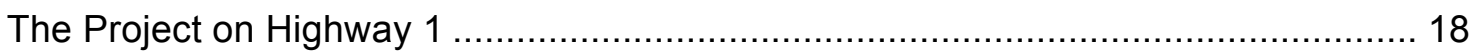

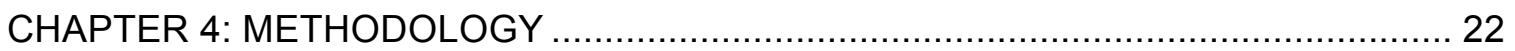

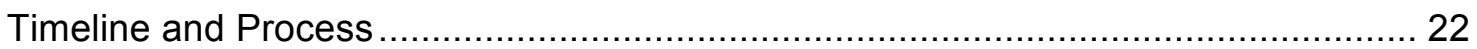

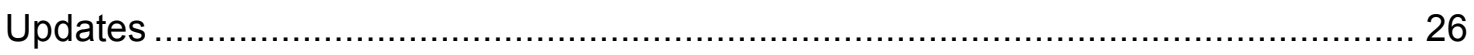

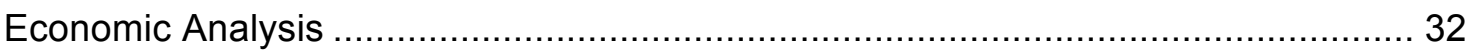

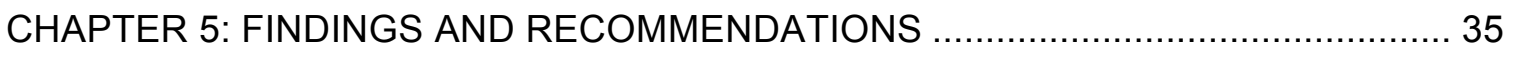

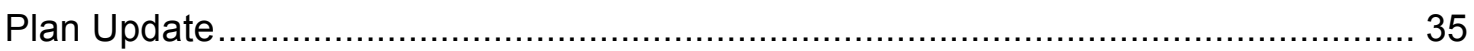

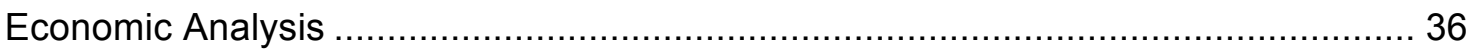

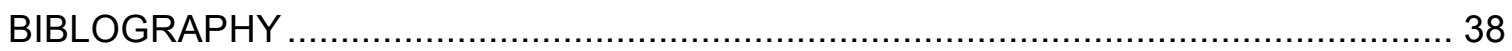

APPENDIX: ROUTE 1 SAN LUIS OBISPO NORTH COAST SCENIC BYWAY

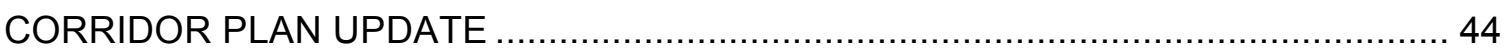




\section{LIST OF FIGURES}

FIGURE 4.1: PROJECT TIMELINE

FIGURE 4.2: 2007 MAP VS. 2014 MAP .

FIGURE 5.1: DIRECT AND INDIRECT IMPACTS 


\section{CHAPTER 1: INTRODUCTION}

The stretch of California Route One (Highway 1) from the City of San Luis Obispo reaching north to the Monterey County line is one of the most scenic drives in the United States. This stretch of highway is federally designated as an All-American Road, the highest scenic designation of any road or highway in the nation. This designation requires the San Luis Obispo Council of Governments (SLOCOG), the federally designated National Scenic Byway Organization for the SLO North Coast Scenic Byway, to maintain an updated Corridor Management Plan. The Corridor Management Plan for this stretch of highway is titled, Route 1 San Luis Obispo North Coast Scenic Byway Corridor Plan, and it was updated as a result of this professional project. Designation was originally pursued for increased funding opportunities from the Federal Highway Administration (FHWA) to help preserve and enhance the corridor. However, this funding was removed in 2012 as part of the federal transportation bill (MAP-21) reauthorization.

Even though funding for scenic programs has been removed, SLOCOG continues to recognize the importance of the corridor in attracting valuable tourism revenue thus the importance to the region's economic vitality. The project involved two main tasks: an update to the 2007 Route 1 San Luis Obispo North Coast Scenic Byway Corridor Plan and a way to quantify the scenic byway's impact on the region. The update was completed as a result of considerable stakeholder engagement, research, and editing. During the update process, stakeholders were involved, information was gathered, Byway Committee meetings were held, the document was restructured, and an economic analysis was performed using the America's Byways $₫$ Resource Center's Economic Impact Tool. After nine months of updating and analysis efforts, the plan was presented and unanimously approved by the Byway Committee, all three of SLOCOG's advisory committees, and the Board of Directors in June of 2014. 
The following document was created as documentation of the research collected, the nine-month process, and the findings from the analysis. The document begins with a literature review in Chapter 2 focused on the history of early conservation efforts, the creation of the national scenic byway program, the program's associated funding sources, and the financial benefits tourism has along scenic routes. Delving into this research provided an approach to the Scenic Byway Plan update and economic analysis. Chapter 3 provides the background to the scenic byway program in San Luis Obispo County and the process it took to get local designation. Chapter 4 explains the methodology behind the plan update and the economic analysis. This information then informs the findings from the project in Chapter 5. 


\section{CHAPTER 2: LITERATURE REVIEW}

\section{EARLY CONSERVATION IN THE UNITED STATES}

Peak land exploration in America happened during the 1860 s as a result of large land acquisitions such as the Louisiana Purchase (O'Brien, p.20, 1999). Land gained from these acquisitions was quickly privatized; however, some activists had the foresight to promote parkland preservation. The first successful preservation campaign was around what is now Yosemite National Park. Yosemite is one of the first National Parks and is credited with inspiring the national parks movement (Engbeck, 1980). Early parks like Yosemite were successful because they were seen as scenic and were not originally thought to possess important economic resources (O'Brien, p. 21, 1999). Through the passage of the Yosemite Park Act of 1864, the first rural natural landscape in the county was set-aside as a park. The fact that the Supreme Court upheld that homesteading on public lands was illegal solidified the conservation movement (O’Brien, p. 21, 1999). Conservation in the country began to take hold but providing adequate funding for these efforts was scarce.

Financial support for the national park system was limited from inception. Parks turned to tourism to provide necessary maintenance and means of operation. Finding a balance between providing enough visitor access while keeping scenic locations pristine was difficult and continues to create conflicts throughout the national park system. By 1950, nearly 32 million Americans headed to national parks each year, and the entire park system was under significant strain (The National Parks: America's Best Idea, 2009). During this period, there was an increase in industry and major metropolitan growth that created an increase in disposable income. The rise of the private automobile and additional income boosted tourism and the need for improved and increased access to scenic locations. 
Almost one hundred years after the national parks system began, the 1960s brought noticeable change to the urban environment attributed to rapid industrialization and sprawling growth (Engbeck, 1980). A demand for more parks paralleled the demand for convenient visitor access. According to the Department of Commerce's Proposed Scenic Byway Program Report, driving for pleasure was America's most popular outdoor recreational activity in 1966 accounting for $42 \%$ of the total annual outdoor activity (Connor, p.15). However, the supply of recreational space such as national parks was not geographically accessible to many of the Americans looking for an escape from the industrial cities. In 1966, two out of three people who lived in or near the largest cities in America were not within convenient driving distances of the country's major parks and forests (Connor, p.17, 1966). Over $70 \%$ of the land available for public recreation was located in the West, but during this time only $15 \%$ of the county's population lived in the region (Connor, p.17, 1966). The fact that people were driving more with money to spend created the concept of a traditional tourist in modern America. Attracting these tourist to open space was a way to gain revenue for scenic locations that were struggling to keep up maintenance and operational costs. Providing a way to access national public spaces was a need and the solution was the creation of the national scenic byway program. Scenic byways were created to bridge the geographical gaps between the tourists and picturesque national locations; however, these roadways slowly began to be considered destinations in their own right.

\section{BUILDING MOMENTUM}

In the 1960s, the environmental movement began to pick up as a result change of political leadership, increased pollution concerns, and tourism demands (O'Brien, p. 29, 1999). Urban development and growth, especially in California, was oriented around personal automobile use with the catalyst being the subsidized highway development of the Federal Highway Act of 1956 (Engbech, 1980). People were looking for somewhere 
to recreate but had to travel to get to a majority of large public spaces such as parks and downtown cores. Cultural, environmental, and economic factors converged to bring about the scenic byway program.

Starting in the 1960s, preserving scenic locations and roads that provided access to these designations were both studied as sources of cultural and environmental resource protection and economic creation. The Recreation Advisory Council was created in 1962 under Executive Order 111017 by President John F. Kennedy to pinpoint recreational opportunities for Americans (Connor, 1966). This council provided policy advice on matters affecting outdoor recreation resources and was tasked with facilitating a coordinated effort among various Federal agencies. The Council issued a policy statement recommending the creation of a national scenic byway program. They provided five reasons why the creation of this program would be important to the county's recreational resources:

- Driving for pleasure was stated as one of "America's most popular outdoor recreation pursuits."

- There was an increase in the amount of car ownership and leisure time.

- Increase in urban growth is requiring the need for more open space.

- It was believed that tourism would be generated by making the roadways more attractive thus positively impacting the economy.

- As a result of future road planning, design, and construction activities there would be great potential gains in esthetic and recreation benefits (Connor, 1966).

A year later, President Lyndon B. Johnson laid the foundation of this program through his message on Natural Beauty to Congress. In 1965, he stated, 
"More than any other country, ours is an automobile society. For most Americans, the automobile is a principal instrument of transportation, work, daily activity, vacation, and pleasure. By making our roads highways to the enjoyment of nature and beauty, we can greatly enrich the life of nearly all our people in city and countryside alike. Our task is two fold. First, to ensure that roads themselves are not destructive of nature and natural beauty. Second, to make our roads ways to recreation and pleasure" (The National Conference on State Parks, p.5, 1965).

Through this speech, the president acknowledged the need for conservation and careful consideration when trying to increase access to scenic locations. President Johnson made reference to the importance the automobile played the county's movement as well as the need to find a balance between access and conservation. With this statement, the desire of an official program was expressed by an understanding that the automobile tourist was going to be the future of maintaining conservation efforts. In 1965, the U.S. Congress enacted the Highway Beautification Act (US DOT Federal Highway Administration, 2013). This Act continued to build the development of a scenic byway program.

Seeing the trend of automobile tourism created the scenic byway program. A large selling point of the program was the fact that it would create a much-needed source of revenue for communities and parks located on scenic roadways. Funding would help enforce the fact that intrinsic qualities of a particular region needed to be preserved to maintain the tourism revenue. This investment was also seen a huge economic generator so much so that it was stated by the Department of Commerce that travelers in 1966 spent around $\$ 30$ billion annually in the United States (Connor, p.3, 1966). According to the Bureau of Economic Analysis, in the first six months of 2014, tourism created over $\$ 3.03$ trillion across the nation's economy (2014). Accounting for 
inflation that would be almost $\$ 416$ billion in $1966^{1}$ just in the first half of the year. In about 50 years, the tourism industry in the United States has increased significantly.

In 1966, The Recreation Advisory Council, published A Proposed Program for Scenic Roads and Parkways (Federal Highway Administration, 1990, p.1). The two hundred and fifty page report outlined the benefits a scenic program could have on the nation including national defense, safety, health, conservation, and economic well being (Connor, p.2, 1966). The report stated at least one-third of all US motor travel was for the purpose of social, recreational, or vacation purposes (Connor, p.1, 1666). This report again showed that a national byway program was a viable option to meet the need of Americans driving for pleasure. Using the argument that in the future citizens will have more free-time, they seek more recreational opportunities, they have increased income, and a continued desire to drive vehicles for pleasure, the case was make to implement a national scenic byway program.

Momentum was gaining in Washington D.C. to establish a program and some states began implementing programs to help guide local jurisdictions or non-profits through individual state managed designation processes. By gaining local support early on, these early adopter states were better positioned to apply for possible funding assistance through the federal program. In California, this program was created in 1963 with Bill 1467. The Bill stated, "the development of scenic highways will not only add to the pleasure of the residents of this State, but will also play an important role in encouraging the growth of the recreation and tourism industries upon which the economy of many areas of this State depend" (Caltrans, p.2, 2008). States, such as California, recognized the importance of initiating a program for the economic,

\footnotetext{
${ }^{1} \$ 3.03$ trillion $/ \$ 7.25=\$ 4.16$ billion $\mathrm{http}: / /$ data.bls.gov/cgi-

bin/cpicalc . l $? \operatorname{cost1} 1=1.00 \&$ year1 $1=1966 \&$ year $2=2014$
} 
recreational, and conservation benefits it would bring to local jurisdictions and the state as a whole.

Seven years following the publication of the Recreation Advisory Council's $A$ Proposed Program for Scenic Roads and Parkways, the Federal Highway Administration studied the findings and published a new document entitled, Assessment of the Feasibility of Developing a National Scenic Highway System, in 1973 (US DOT Federal Highway Administration, 2013). From the findings within this document, it was recommended that the scenic byway program should not consist of a scenic byway specific grant program due to the government's push for energy conservation after the oil embargo. President Ronald W. Reagan almost fifteen years later established the Commission on Americans Outdoors, which updated the findings from the Outdoor Recreation Resources Review Commission (ORRRC) in 1960 (US DOT Federal Highway Administration, 2013). Three recommendations were made that included the scenic byway program in the Commission on Americans Outdoors' 1987 report. The Commission on Americans Outdoors recommended that state and local governments should create a network of scenic byways and protect the resources, congress should provide grant opportunities, and there should be government and private sector partnerships when disseminating information about these locations (US DOT Federal Highway Administration, 2013).

\section{A PROGRAM OVER 30 YEARS IN THE MAKING}

As a result of the 1987 report from the ORRRC the Scenic Byway program began to take shape with the passage of the 1990 Department of Transportation and Related Agencies Appropriation Act. The Act directed the Department of Transportation to report on four objectives. According to the Federal Highway Administration, the objectives were to:

- Update an inventory of existing scenic byways nationwide 
- Create guidelines to establish a National Scenic Byway Program

- Conduct Case Studies of the economic impact of scenic byways

- Analyze potential safety consequences and environmental impacts associated with scenic byway designation (1990, p.1).

A nationwide survey was sent out to the transportation departments focused on the success of the byway program. California responded by stating the program was successful, but interest in the program depended on environmental attitudes. The program began when preservation was thought to be important and as movements for historical preservation renewed so did the interest in the program (Federal Highway Administration, 1990, p.1).

In 1991 with the passage of the Intermodal Surface Transportation Efficiency Act (ISTEA), the National Scenic Byway Program was officially established. The program began with funds totaling $\$ 50$ million for planning, design, and development of State scenic byway programs (National Transportation Library, 1991). The program also allowed for ten percent of enhancement funds of the Surface Transportation Program, which focuses on transportation improvements that are not centered on automobile transportation. (National Transportation Library, 1991). The ISTEA established the Transportation Enhancements (TE) program and began a legacy of including active transportation programs and projects in federal surface transportation bills (American Society of Landscape Architects, 2015).

The same year the Scenic Byways Act of 1991 was passed which established the Office of Scenic Byways in the Federal Highway Administration. According to the Congressional Research Service (CRS), this office was to:

(1) provide information regarding activities and programs for scenic byways;

(2) endorse the existence and use of scenic byway funds 
(3) maintain an inventory of highways for designation

(4) carry out the planning, research, and technical assistance duties of the Department of Transportation (DOT) with respect to the national scenic byways program (1991).

Section 1047 established an Advisory Committee that was composed of 17 members. This committee was multi-disciplined in tourism, parks, and transportation. Under the Act, the Secretary of Transportation was to establish criteria for designating highways as Scenic Byways and All-American Roads, including scenic beauty and historic significance considerations, operation and management standards, and standards for signs, safety, facilities, and landscaping (CRS, 1991). If States had existing programs, they were eligible for project grants and those that did not have programs could apply for grants to create a scenic program. The states that did not have existing programs would be funded up to eighty percent through the federal program (CRS, 1991).

According to the Scenic Byways Act of 1991, there were six types of projects that were eligible for funding (Thomas - Library of Congress, 1991). Planning, design, and development of State scenic byway program were a way to receive funds. One of the top priorities of the program was to increase safety along the corridor so adding safety improvements to a highway designated as a scenic route was another eligible project. The program also wanted to improve recreation along the corridors. Construction of facilities used by pedestrians and bicyclists including rest areas, turnouts, highway shoulder improvements, passing lanes, overlooks, and interpretive facilities were qualified projects. Projects that protected historical and cultural resources in areas adjacent to the highway could receive funds. Since this program centered on tourism the development and distribution of tourist information to the public, including interpretive information about the scenic byway also qualified for national scenic byway funds. 
States that had existing byway programs could apply for funding. Once the applications were received, the committee acknowledged priorities when distributing project grants. The programs that were given priority encompassed one or more of the following:

- Projects that were included in a corridor management plan while providing for accommodation of increased tourism and development of related amenities

- Projects for which a strong local commitment is demonstrated for implementing the management plans and protecting the byway's characteristics.

- Projects in which they serve as models for other States to follow when establishing and designing scenic byways on an intrastate or interstate basis

- Projects in multi-State corridors where the States submit joint applications (Thomas - Library of Congress, 1991).

Funding for the program continued to improve with the passage of the Transportation Equity Act for the 21st Century (TEA-21) in 1998 and the Safe, Accountable, Flexible, and Efficient Transportation Equity Act - A Legacy for Users (SAFETEA-LU) in 2005 (Scenic America, 2006). Almost \$150 million in grants were authorized through TEA-21 to assist States with the creation of scenic byway programs and fund projects along roads already designated (Federal Highway Administration, 2011). Together, SAFETEA-LU and TEA-21 funding covered $80 \%$ the National Scenic Byway project costs, but required a 20\% local match (Scenic America, 2006). In 2009, SAFETEA-LU expired and surface transportation programs were carried out through a series of legislative extensions of SAFETEA-LU (American Society of Landscape Architects, 2015). 


\section{ACTIVE TRANSPORTATION PROGRAM}

Moving Ahead for Progress in the 21st Century Act (MAP-21) was signed into law in 2012 reauthorizing the nation's surface transportation laws at current spending levels through 2014 (American Society of Landscape Architects, 2015). The

Transportation Enhancements (TE) program was renamed to Transportation Alternatives Program (TAP). Within this program the National Scenic Byways Program was cut; however, there are some projects that are eligible for funding in category four (American Society of Landscape Architects, 2015). There were six categorizes with twelve eligible project types including construction of turnouts, overlooks, viewing areas, historic preservation and rehabilitation of historic transportation facilities, vegetation management, and inventory control of outdoor advertising (American Society of Landscape Architects, 2015).

In 2013, the federal funding from TAP was consolidated into the California Active Transportation Program (ATP) along with other state transportation programs, such as Bicycle Transportation Account and State Safe Routes to School (Caltrans, 2014). ATP is a program focused on making California a national leader in active transportation by encouraging increased use of active modes (Caltrans, 2014). According to Caltrans, the goals of the program are to:

- Increase the proportion of trips accomplished by biking and walking,

- Increase safety and mobility for non-motorized users,

- Advance the active transportation efforts of regional agencies to achieve greenhouse gas $(\mathrm{GHG})$ reduction goals,

- Enhance public health, 
- Ensure that disadvantaged communities fully share in the benefits of the program, and

- Provide a broad spectrum of projects to benefit many types of active transportation users (2014). 


\section{CHAPTER 3: BACKGROUND}

\section{REQUIREMENTS}

\section{State Requirements}

Before becoming a National Scenic Byway or an All-American Road, the corridor needs to be recognized as a State Scenic Byway. To start the state recognition process, the byway must first be on the statutory list of highways eligible for scenic designation in the State Scenic Highway System under Section 263 of the Streets and Highways Code (Caltrans, 2008). According to the California Scenic Highway Guidelines, the state evaluates scenic roadways using the following criteria:

- The roadway must consist of a scenic corridor that is comprised of a memorable landscape that showcases the natural scenic beauty or agriculture of California.

- Visual intrusions do not significantly impact the scenic corridor.

- There is a demonstration of strong local support for the proposed designation.

- The proposed scenic roadway is greater than a mile and is continuous (Caltrans, p.2, 2008).

After the state route is formally recognized in the Streets and Highways Code Section 263 , the local governing body with jurisdiction of the surrounding scenic location has the opportunity to it nominate the corridor for official state designation. Both a visual assessment and a Scenic Highway Proposal are required as an application to officially nominate a scenic highway. The Scenic Highway Proposal includes a local governing body's letter of intent, both topographic and zoning maps, and a narrative depiction of the scenic qualities along the corridor (Caltrans, 2008).

National Requirements

Before being recognized by the federal government as a scenic byway, the road must be designated as a State Scenic Byway. This road should be as continuous as 
possible to create a better visitor experience. It also needs to be safe and accessible to accommodate two-wheel drive automobiles to be considered and should also accommodate multi-modal travel (bicycle and pedestrian) when possible (Federal Highway Administration, 1995). There are also requirements that are centered on tourism of the byway. The road should safely accommodate conventional tour buses and convenience facilities should be available. With all these considerations, there needs to be a corridor management plan that is associated with local enforcement.

Designation as a National Scenic Byway requires the road to be regionally significant and possess at least one of the six intrinsic qualities (described below). These roads are often the "roads less traveled" but have history and cultural unique to the region (United State Department of Transportation, 2002). There are two levels to the designation: Scenic Byway and All-American Road. To be an All-American Road, a road must embody multiple intrinsic qualities; making the road a unique one-of-a-kind destination. The road should be the destination that provides an incomparable traveling experience, which makes the drive along the highway a focal point of the trip (United State Department of Transportation, 2002). According to the National Scenic Byways Program, there are 75 National Scenic Byways and 20 All-American Roads in 39 states (2002).

According to the Department of Transportation's Interim Guidelines to the National Scenic Byway Program, there are six defined intrinsic qualities (1995). These qualities include scenic, natural, historic, cultural, archeological, and recreational. To possess scenic qualities, the region must offer a distinct visual experience made up of all elements of the landscape presenting a positive visual environment (Department of Transportation, 1995). The Department of Transportation defines a scenic quality as, "Heightened visual experience derived from the view of natural and manmade elements of the visual environment of the scenic byway corridor" (1995). Qualities that are not 
manmade with minimal disturbances are included in the criteria for natural qualities. Historic qualities are associated with the physical landscape but also encompass the past, which educate the viewer of the historic significances (Department of Transportation, 1995). Cultural qualities are expressed though evident customs and traditions of a certain group of people (Department of Transportation, 1995). Archeological Qualities are indicated as physical remnants of historic human life present in the region (Department of Transportation, 1995). Recreational Qualities provide users the opportunity to get involved with the local environment and explore the elements of the location.

\section{CORRIDOR MANAGEMENT PLANS}

Corridor management plans represent the vision of the corridor and help a community reach agreement about the course of action in protecting the region's scenic qualities (Paul Daniel Marriott \& Associates, 1995). These are required to help coordinate and build consensus. Generally, corridor management plans are not legally binding documents; however, they may be formally endorsed and adopted as policy (Paul Daniel Marriott \& Associates, 1995). These plans provide local groups with a coordinated channel to accomplish common goals and create a conversation for the community that continues long after the plan is adopted. Corridor management plans require continuous dialog to successfully create recommendations and see them implemented (Paul Daniel Marriott \& Associates, 1995). According to the Federal Register 26759 / Vol. 60, No. 96, there are fourteen points that need to be covered when developing a corridor management plan:

1. "A map identifying the corridor boundaries and the location of intrinsic qualities (scenic, historic, cultural, natural, recreational and archaeological) and different land uses within the corridor.

2. An assessment of such intrinsic qualities and of their context. 
3. A strategy for maintaining and enhancing those intrinsic qualities.

4. A schedule and a listing of all agency, group, and individual responsibilities in the implementation of the corridor management plan, and a description of enforcement and review mechanisms, including a schedule for the continuing review of how well those responsibilities are being met.

5. A strategy describing how existing development might be enhanced and new development might be accommodated while still preserving the intrinsic qualities of the corridor. This can be done through design review, and such land management techniques as zoning, easements, and economic incentives.

6. A plan to assure on-going public participation in the implementation of corridor management objectives.

7. A general review of the road's or highway's safety and accident record to identify any correctable faults in highway design, maintenance, or operation.

8. A plan to accommodate commerce while maintaining a safe and efficient level of highway service, including convenient user facilities.

9. A demonstration that intrusions on the visitor experience have been minimized to the extent feasible, and a plan for making improvements to enhance that experience.

10. A demonstration of compliance with all existing local, State, and Federal laws on the control of outdoor advertising.

11. A signage plan that demonstrates how the State will insure and make the number and placement of signs more supportive of the visitor experience.

12. A narrative describing how the National Scenic Byway will be positioned for marketing. 
13. A discussion of design standards relating to any proposed modification of the roadway. This discussion should include an evaluation of how the proposed changes may affect on the intrinsic qualities of the byway corridor.

14. A description of plans to interpret the significant resources of the scenic byway" (1995).

These were the basis in which the Route 1 San Luis Obispo North Coast Scenic Byway Corridor Plan was created and updated.

\section{THE PROJECT ON HIGHWAY 1}

Winding through San Luis Obispo County on California's Central Coast is a section of State Route 1 that provides a truly remarkable experience to travelers. Highway 1 between the city limits of San Luis Obispo and the northern San Luis Obispo County line is one of the most picturesque in all of California.

The highway stretches through valleys, along coastal ranges and the Pacific Ocean, into Monterey pine forests, on top of coastal terraces, and finally along sheer cliffs. The journey offers travelers an unsurpassed experience of California's coastline in a nearly pristine state boasting both natural and human elements that provide a unique traveling experience.

The San Luis Obispo North Coast Scenic Byway was designated as an AllAmerican Road by the Federal Highway Administration on August 8, 2003. This level of scenic designation is reserved for routes that possess nationally significant resources (intrinsic qualities) and is the highest scenic designation of any road or highway in the nation. The Route 1 San Luis Obispo North Coast Scenic Byway Corridor was designated as a result of the scenic, natural, recreational, and historical qualities that draw visitors from around the country and around the world. Coupled with the Big Sur Coast All-American Road, which begins at the San Luis Obispo/Monterey County Line 
and courses along the rugged coastline north through Big Sur to Monterey, the highway provides one of the best traveling experiences in the world.

It is the objective of this plan update is to identify how this corridor will retain its irreplaceable scenic resources, while enhancing the communities and facilities within it for its residents and travelers of the highway for generations to come.

Following the designation of Highway 1 as a State Scenic Highway in 1999, SLOCOG initiated the process of pursuing the inclusion of the highway into the Federal Highway Administration's (FHWA) National Scenic Byways program. The program designates those highways that exhibit qualities that distinguish the corridor from others around the state and country as either a "National Scenic Byway" or an "All-American Road.”

At a minimum, National Scenic Byways are those highways that have at least one quality significant to a two state region. The more selective of the two types of national byways, the "All-American Road" designation, is reserved for those highways that are "destinations unto themselves," possess at least two qualities that are significant on a national level, and one that is unparalleled in the country.

Designation into the program requires three things: existing officially designated State Scenic Highway status, the highway corridor meeting one of the two definitions identified in the preceding paragraph, and a plan that identifies how the corridor's special attributes will be protected and enhanced. This plan fulfills the last of these requirements. The Byway Corridor Plan (BCP) was first adopted in February 2002. It was structured largely to meet the requirements of the Scenic Byways Program.

While the National Scenic Byways program was eliminated under MAP-21, some projects are eligible under category 4 of Transportation Alternatives Program. Eligible projects under the Intermodal Surface Transportation Program and the Transportation Alternatives Program that may have previously been eligible as part of the National 
Scenic Byways Program include the construction of turnouts, overlooks, and viewing areas; historic preservation and restoration of historic transportation facilities related to a byway; and bicycle and pedestrian facilities along a byway. Support through a Scenic Byway Corridor Plan will increase the competitiveness of projects applying for discretionary funding under new federal and state sources.

The North Coast Scenic Byway exhibits four out of six nationally recognized intrinsic qualities. These qualities include natural, historic, scenic, and recreational. The Corridor Management Plan referred to the Scenic Byway Plan recognizes the following examples in Chapter One:

- Scenic: Santa Lucia Coastal Range, Ragged Point, The Morros, and Estero Bay

- Historical: Piedras Blanca Lighthouse, Hearst Castle, Mission De San Luis Obispo, and Camp San Luis Obispo

- Natural: California Coastal National Monument, Monterey Bay National Marine Sanctuary, Elephant Seal Colony, Estero Bluffs State Park, Morro Bay Estuary, and Elfin Forest

- Recreational: Hearst San Simeon State Park, Fiscalini Ranch, Harmony Headland State Park, Morro Strand and Cayucos State Beaches, Morro Bay Harbor/Estuary, Morro Bay State Park, Montana de Oro State Park, and Bishop Peak

The above qualities are what distinguish the corridor from others in the state and nation. They are also the basis for the corridor's designation as an All-American Road, the highest scenic designation of any road or highway in the nation through the National Scenic Byways Program. Descriptions of these locations accompany a photo in the update to the Scenic Byway Plan and can be found in the Appendix. These qualities were specifically identified through community outreach during the initial creation of the plan in 2007 and during the 2014 update. 
The scenic qualities of the Corridor are a primary reason behind visitor's desire to be in the region. The corridor includes a number of natural features that provide travelers with a mosaic of aesthetic scenes. While traveling from the City of San Luis Obispo north through the Corridor, travelers are able to view the above features using both vehicles and active transportation modes (walking, bicycling, hiking, etc.). 


\section{CHAPTER 4: METHODOLOGY}

\section{TIMELINE AND PROCESS}

During the Scenic Byway Corridor Plan's creation, the San Luis Obispo Council of Governments assembled a committee to serve as an advisory and primary guiding body for byway planning. This committee is currently comprised of ten main stakeholders including California Department of Transportation (Caltrans), City of San Luis Obispo, County of San Luis Obispo, City of Morro Bay, Cayucos Advisory Council, North Coast Advisory Council, Cambria Community Service District, San Simeon Community Service District, California Department of Parks and Recreation, and San Luis Obispo Regional Transit Authority. This committee does not meet regularly but during the update the committee was brought together every other month. Representatives from the ten organizations in the committee provided important institutional knowledge and background during the process.

After the original creation, the document was not routinely tracked due to the fact that the committee was seldom convened because the plan does not include additional regulations to land use. The document, like the majority of corridor management plans throughout nation, does not have regulatory teeth to hold local justifications accountable for preserving the scenic qualities along the corridor unless local policies are adopted. The Scenic Byway Plan does not introduce any regulatory restrictions or policies but summarizes current state and local regulations protecting the scenic qualities. The document does provide a framework to implement local policies and serves as a reference by inventorying past progress, current conditions, and future suggestions.

Even though the committee was not actively engaged in the scenic byway and the document does not carry regulatory weight, SLOCOG staff continued to pursue funding and implement projects along the corridor. SLOCOG, as the lead agency, has received nearly $\$ 900,000$ in grant assistance through the National Scenic Byway Program (San 
Luis Obispo Council of Governments (SLOCOG, 2015). The update funding came from an $80 \%$ funded National Scenic Byway grant $(\$ 20,000)$ and a local match of $20 \%$ $(\$ 5,000)$. Since the National Byway Program funding was removed in 2012, SLOCOG received an extension on the funding and the project began in September 2013. SLOCOG staff continued to pursue the plan update because of the possibility of future program funding reallocation. Also, SLOCOG recognized the importance the Byway continues to have on the local economy and wanted to quantify its' impact to defend continued awareness and enhancement efforts along the Corridor. The National Scenic Byway Grant allowed for the creation of a temporary Transportation Assistant position to focus on updating and improving the current corridor management plan. This later became a project management position.

In September 2013, the update began with the creation of a project timeline. The funding was set to expire at the end of the fiscal year (June 2014), so the project had to be finished in May before the June SLOCOG Board Meeting. The timeline that was created can be seen below in FIGURE 4.1. 
FIGURE 4.1: PROJECT TIMELINE

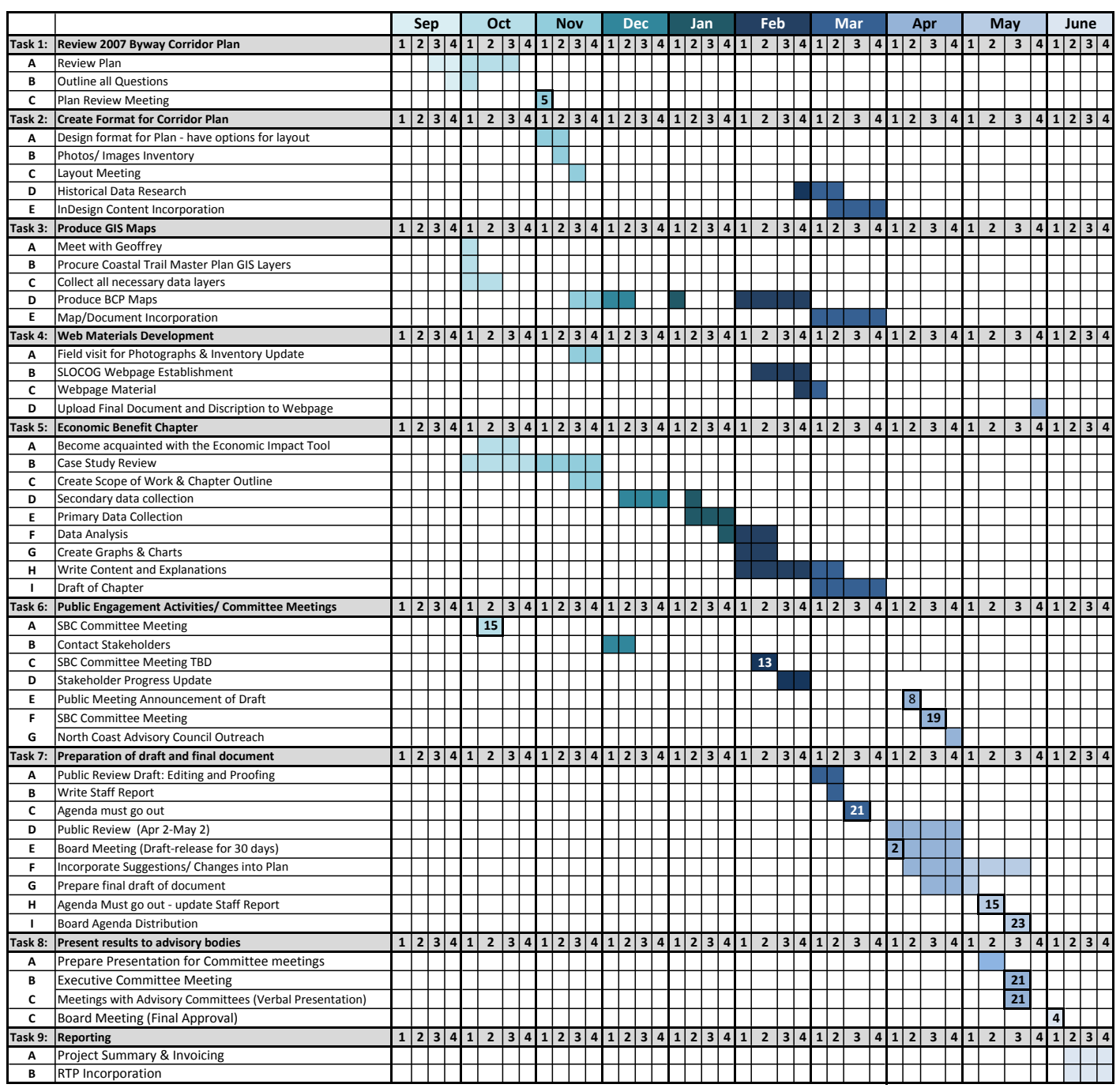

FIGURE 4.1 is the project timeline used to complete the tasks of the Byway Plan

update. There were nine main tasks and subtasks within each task sector. The timeline was divided up into weeks of each month. Certain subtasks included specific dates.

The first two months were dedicated to reviewing the existing document and understanding the intentions of the Plan. The 2007 Plan was divided into two main sections, the first described current conditions and the second was dedicated to possible improvement/enhancement projects. The flow of the 2007 Plan lacked structure and a consistent format. After the first in-depth review, information provided by the federal 
program resolved most document misunderstandings. This research was important to the process because understanding the intentions of the national program allowed for a better understanding of the local intentions throughout the update. The upfront program research allowed for the right questions to be asked and document improvement ideas to be created. The first round of document analysis was followed by research and another round of editing. The staff planner reviewing this work then went through the list of suggestions and addressed the questions that were still unanswered.

A month later, the staff planner responsible for reviewing the project left. I became the project manager for the Scenic Byway Corridor Plan Update. This added responsibility required a timeline adjustment and compromises from the Scenic Byway Committee. There was also an increased reliance on the Committee for historical information. During the first Scenic Byway Committee meeting as Project Manager, I led the meeting's discussion to focus on the timeline, layout, and organization of the existing document. In this meeting, it was agreed that the Plan was missing organization. It was limited by the fact that it had two sections, the organization of the entire document was very incoherent, and the plan focused on marketing the byway as opposed to enhancing its' intrinsic qualities. An overhaul of the document hierarchy was required.

After this meeting the 2007 Plan was broken up into small portions for the Byway Committee to review and make corrections or suggestions. This approach worked because the time commitment seemed minimal when the reading requirements were broken up. As the project manager, I took the lead on updating most of the document and then distributed the draft to the Committee in small manageable sections. After the draft of each section was distributed, a timeframe to provide feedback was set. After all committee suggestions were received, the comments were noted and incorporated into the document. The design and layout of the updated document was then vetted and approved through the committee. 
The full document including the economic analysis was due to the Committee in early May 2014. This was about a month before it would be presented to the Board of Directors. Comments were received and approval of the document was sent in via email from the Scenic Byway Committee members by May $12^{\text {th }}, 2014$. As required by SLOCOG, two weeks before the Board Meeting, a staff report must be posted and presented to the advisory committees. The document was presented to the committees and was unanimously recommended. On June $4^{\text {th }}, 2014$, the final presentation was made and the Board unanimously accepted the update and economic analysis.

\section{UPDATES}

The Byway Corridor Plan update focused on refining the 2007 Plan's comprehensiveness, document layout, mapping, and the economic benefits provided by the corridor. The fourteen mandatory elements of a Byway Corridor Management Plan were used to update the document and built upon the existing elements to improve and increase the Byway Plan's robustness. The update focuses on streamlining the main takeaways of the Byway Plan. The two original sections were divided to create four chapters. These chapters are outlined below:

- $\quad$ Chapter 1: North Coast Scenic Byway Corridor - Within Chapter 1, the existing conditions are described, the corridor communities are outlined, and the intrinsic qualities are detailed.

- Chapter 2: Byway Vision and Planned Improvements-the Byway's vision is expressed, the programs associated with establishing the vision are described, completed and current improvement projects are defined, and maps of these improvement projects are included to visually understand the area's conditions.

- $\quad$ Chapter 3: Administration- the plan update process is laid out, funding opportunities are explored, and technical assistance for finding more detailed information is stated. 
- $\quad$ Chapter 4: Economic Benefits - The information is new to the plan. This chapter uses economic analysis data to quantify the financial impact tourism plays along the Byway.

Updates to the chapters were based on the fourteen elements of the Corridor Management Plans detailed in the Federal Byway Program. Below are the requirements for Corridor Management Plans recognized by the National Scenic Byway Program and the improvements made during the recent update. The 2014 Route 1 San Luis Obispo North Coast Byway Corridor Plan can be referenced in the Appendix.

- A map identifying the corridor boundaries and the location of intrinsic qualities (scenic, historic, cultural, natural, recreational and archaeological) and different land uses within the corridor (FDOT, 1995). 
BEFORE

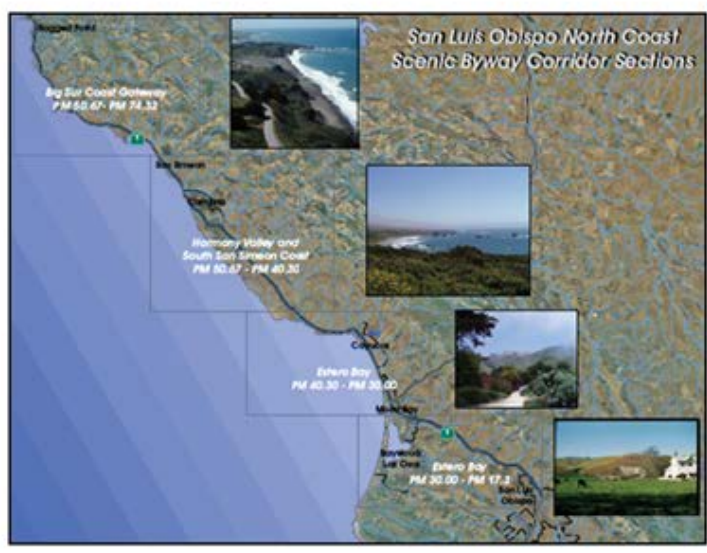

AFTER

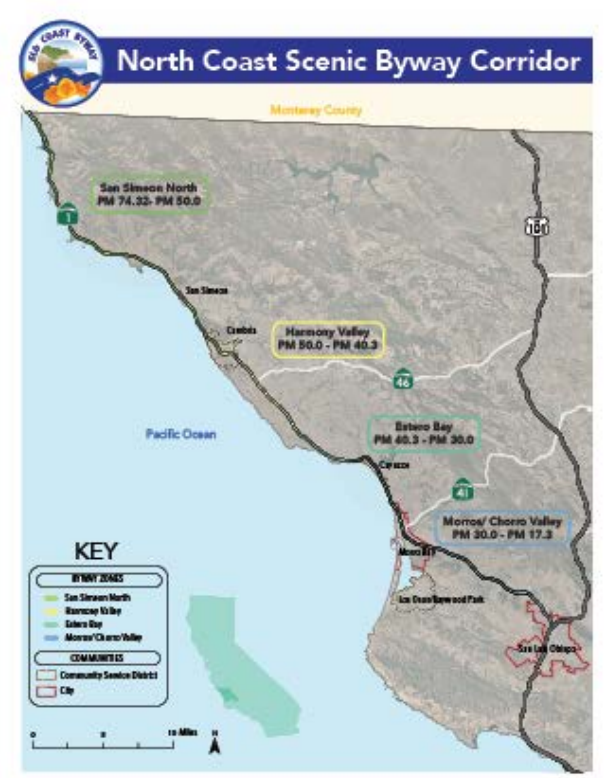

FIGURE 4.2 showcases the change in mapping technology and technique. The 2007 version is busy and not focused on the Byway. The 2014 version is clean and straightforward. Staff used both GIS and Abode Illustrator to accomplish uniform and informative maps. There are six updated maps in the 2014 update. Staff went through each point of interest labeled on the 2007 maps and updated, removed, or added locations.

- An assessment of such intrinsic qualities and of their context (FDOT, 1995).

The intrinsic qualities section was updated through the Byway Committee. Each member took sections that were relevant to their organization and improved the content. Staff then went to these locations and documented the current conditions through written descriptions and photos. Select photos were used above each intrinsic quality heading.

- A strategy for maintaining and enhancing those intrinsic qualities (FDOT, 1995). 
This element can be found in both Chapters Two and Three. Chapter Two delves into the current local policies that protect these intrinsic qualities, the programs that are improving the Byway, and the maps that show current and future Byway improvements. Chapter Three showcases the current programs that can possibly fund the listed improvements along the Corridor.

- A schedule and a listing of all agency, group, and individual responsibilities in the implementation of the corridor management plan, and a description of enforcement and review mechanisms, including a schedule for the continuing review of how well those responsibilities are being met (FDOT, 1995).

This element can be seen in the Chapter 1 of the 2014 update. There is a section that provides key county policies relating to growth and resource management along the Byway. The Scenic Byway Committee as well as the stakeholders are listed in the introduction.

- A strategy describing how existing development might be enhanced and new development might be accommodated while still preserving the intrinsic qualities of the corridor. This can be done through design review, and such land management techniques as zoning, easements, and economic incentives (FDOT, 1995).

The Plan does not introduce additional land use regulatory restrictions or policies. It is based on adopted strategies to protect and enhance the Corridor's qualities, which were discussed at length during development of the original Plan. In addition to the locally adopted plans that address land use policies and circulation of the local transportation system, the Plan identifies many of the improvements that are intended for the Corridor by SLOCOG, Caltrans, and local jurisdictions. These projects are primarily associated with maintaining the highway's current configuration with improvements to enhance access and 
aesthetics, maintain operations, and improve how the highway interrelates with the communities it passes through.

- A plan to assure on-going public participation in the implementation of corridor management objectives (FDOT, 1995).

Staff conducted Bi-Monthly Scenic Byway Committee meetings, did extensive outreach involving the members of the North Coast Advisory Committee, and informed over 80 community stakeholders. The 2014 Plan was presented to SLOCOG's Executive Committee, Technical Transportation Advisory Committee, Citizen's Transportation Advisory Council, and Board of Directors. Each one of the outlined program improvements must be vetted through public participation. This is made clear through the document and in local policies and procedures.

- Review of the highway's safety and accident record to identify any correctable faults in highway design, maintenance, or operation (FDOT, 1995).

Safety and operational improvements are discussed in current conditions as well as in the program's section. Caltrans actively participated in the update and provided the data that informed and populated these sections.

- A plan to accommodate commerce while maintaining a safe and efficient level of highway service, including convenient user facilities (FDOT, 1995).

As stated above, Safety and operational improvements are discussed in current conditions as well as in the programs section of the document. Caltrans provided data and approved these sections.

- Demonstration that intrusions on the visitor experience have been minimized to the extent feasible, and a plan for making improvements to enhance that experience (FDOT, 1995).

Chapter One provides a great overview of the elements that make the North Coast Scenic Byway so intriguing. It describes the communities, activities, and 
scenic stops that visitors should take advantage of along the Corridor. Scenic interpretation is also a significant aspect of the Plan update. In Chapter Two, Byway interpretive goals and objectives are discussed, the types of interpretive elements that are found along the Byway are described, and the possibility of additional elements that do not impact the beauty of the area are explored.

- A demonstration of compliance with all existing local, State, and Federal laws on the control of outdoor advertising (FDOT, 1995).

As stated earlier, interpretation is a significant aspect of the plan. In Chapter Two, Byway interpretive goals and objectives are discussed, the types of interpretive elements that are found along the byway are described, and the possibility of additional elements that do not impact the beauty of the area are explored.

- A signage plan that demonstrates how the State will insure and make the number and placement of signs more supportive of the visitor experience (FDOT, 1995). This element is discussed at length in the Interpretive Signage Plan for the North Coast Scenic Byway. It is touched on in the updated document; however, it is explained in full as an attachment in the Plan's appendix.

- A narrative describing how the National Scenic Byway will be positioned for marketing (FDOT, 1995).

As stated above, this element is discussed in the interpretive signage plan for the North Coast Scenic Byway in the Plan's appendix. The previous plan had a detailed account of 2007 marketing practices; however, all of that information was outdated and the Scenic Byway Committee deemed the section unnecessary. The interpretive goal of more fully distributing and publicizing the Byway's intrinsic qualities by utilizing a variety of media (brochures, guides, social media), still remains a goal on page 31 of the updated document. Social 
media was added as a communication outlet because it has become an important information source and marketing tool in the last several years. For example, the popular social media site Twitter $^{\circledR}$ was almost a year old when this document was approved in 2007.

- A discussion of design standards relating to any proposed modification of the roadway. This discussion should include an evaluation of how the proposed changes may affect on the intrinsic qualities of the byway corridor (FDOT, 1995). This element can be seen in the capital improvement project section on page 3740. This section examines viewshed protection, operational and access improvements.

- A description of plans to interpret the significant resources of the scenic byway (FDOT, 1995).

This information can be found on pages 31-36. In this section, a brief history of the interpretation innovations are explained and the goals of the interpretation element are stated. The interpretation section is divided into two sections: interpretation category and interpretation by segment. The category section goes into detail about the types of interpretive media that are found along the Corridor (Visitor Centers, signage, kiosks, spotting scopes, tours, etc.). The interpretation by segment showcases the interpretation elements found in each of the four segments along the Byway.

\section{ECONOMIC ANALYSIS}

SLOCOG commissioned an economic benefits analysis to quantify the impact of the Byway on the region's economy. Having data that shows positive economic impacts will help make the case for continued preservation and enhancement projects along the corridor even after the grant funding has been removed. This analysis was commissioned in the hopes that it would quantify and demonstrate the importance of 
funding scenic projects along the Byway in an increasingly competitive transportationfunding environment. The main sources of information for the economic analysis were the San Luis Obispo Economic Vitality Corporation's 2008 Tourism Report, Dean Runyan Associates' California Travel Impacts, JBG Consulting's 2011 Economic Appraisal: The Mid-Coast of San Luis Obispo County Estero Bay Scenic Byway Trail, and San Luis Obispo County Appraiser Reports. The information found through these sources was then used in the America's Byways Resource Center's Economic Impact Tool: a Microsoft Excel ${ }^{\circledR}$ based economic modeling tool provided by the National Association of Development Organizations. The Economic Impact Tool was created to assist local agencies in monetarily quantifying the impact of scenic corridors removing the investment in time intensive and expensive surveying techniques which are typically done to measure a roadway's performance and use. The tool is based on economic multipliers specified by the U.S. Department of Commerce, Bureau of Economic Analysis (Jensen, 2013). This tool was utilized during the 2011 Economic Appraisal of the Mid-Coast of San Luis Obispo County Estero Bay Scenic Byway Trail, thus the same multipliers were used during this analysis.

One of the primary data sources was the 2008 San Luis Obispo Economic Vitality Corporation's Tourism Report. The main purpose of this study was to understand and make recommendations about tourism, one of the San Luis Obispo County's largest business sectors. This report divided the county into five economic regions, three of which are found along the North Coast Scenic Byway. According to the report, the communities along the Byway provided $50 \%$ of the economic travel impacts for the county, which was the assumption used throughout the study. The analysis inputs were derived using $50 \%$ of the provided spending numbers found in the California Travel Impact Report. Assumptions and inputs can be seen in the Appendix G of the Byway Corridor Plan. The last Byway Plan Update took place in 2007, so it was decided that the 
base year of the analysis would be 2006 and the current year would be 2012 because it had the most recent and abundant data available. The analysis included the following communities: San Simeon, Cambria, Cayucos, the City of Morro Bay, and the City of San Luis Obispo. 


\section{CHAPTER 5: FINDINGS AND RECOMMENDATIONS}

\section{PLAN UPDATE}

The Plan does not introduce additional land use regulatory restrictions or policies. However, it does bring to light an important aspect of continuing the effort of preserving and enhancing the region's intrinsic qualities: the economic impacts of tourism. The 2014 update to the Route 1 San Luis Obispo North Coast Scenic Byway Corridor Plan was intended to identify programs that will maintain and improve the opportunities and experiences of traveling along the Corridor. It also identifies the resources that make the Byway extraordinary and includes how the Corridor is being protected and enhanced.

The Plan attempts to bring together improvement plans of the different regulatory and programming agencies in the Corridor, including San Luis Obispo County, the City of Morro Bay, Caltrans, California Department of Parks and Recreation, Bureau of Land Management, California Coastal Conservancy, California Coastal Commission, and the San Luis Obispo Council of Governments (SLOCOG). This Plan is based on adopted strategies to protect and enhance the Corridor's qualities, which were discussed at length during development of the original plan. In addition to the locally adopted plans that address land use policies and circulation of the local transportation system, the plan identifies many of the improvements that are envisioned for the Corridor by local jurisdictions, SLOCOG, and the State. These projects are primarily associated with maintaining the highway's current configuration with improvements to enhance access and aesthetics, maintain operations, and improve how the highway interrelates with the communities it passes through. SLOCOG recognizes the importance of scenic preservation so much so that the organization went through the process of designating the North Coast Scenic Byway Corridor an All-American Road.

Due the removal of grant funding from the National Scenic Byway Program, an 
economic benefit analysis was performed. The analysis demonstrates the importance of funding scenic projects along the Byway in an increasingly competitive transportationfunding environment.

\section{ECONOMIC ANALYSIS}

Using data from the San Luis Obispo Economic Vitality Corporation's 2008 Tourism Report, Dean Runyan Associates' California Travel Impacts, JBG Consulting's 2011 Economic Appraisal: The Mid-Coast of San Luis Obispo County Estero Bay Scenic Byway Trail, and San Luis Obispo County Appraiser Reports, an economic analysis was performed to quantify the Byway's monetary impact on the region's economy. The information found through these sources was put into the America's Byways Resource Center's Economic Impact Tool.

The study concluded that the Byway has positively contributed to the economy of San Luis Obispo County. Between 2006 and 2012, there was a net increase in number of travelers along the Byway equaling around 1.1 million people. It is estimated that visitation in this region has increased around $20 \%$. This trend of visitors was described in the San Luis Obispo Economic Vitality Corporation's Tourism Impact Study, stating there would be an increase in daytrips and or intra-state overnight travel.

Using the Economic Impact Tool, it was estimated that visitor spending has increased by $23 \%$ from over $\$ 500$ million in 2006 to almost $\$ 656$ million in 2012 . The study also concluded that the Byway has a total impact of visitor spending of about $\$ 217,000$ with restaurants, retail, and lodging contributing to about $66 \%$ of the spending in 2012. The impacts in Exhibit 5.1 are separated into direct impacts, those resulting from the specific economic activities along the Byway, and indirect impacts, resulting from the effects of economic multipliers. Both direct and indirect impacts can be seen in FIGURE 5.1.

In six years, there was a change in the Byway region's total employment with an 
increase of 52,043 jobs and it is estimated that $4.5 \%$ was a result of the Byway. The investments made along the Byway and the increase in visitors had positively impacted the 2012 employment in the region resulting in about 2,300 jobs. The investments made along the Byway can be seen in Appendix F of the 2014 Scenic Byway Plan in the Appendix of this document. In the six years, there had been over $\$ 124$ million in capital improvements along the corridor that have been implemented and or funded.

FIGURE 5.1: DIRECT AND INDIRECT IMPACTS

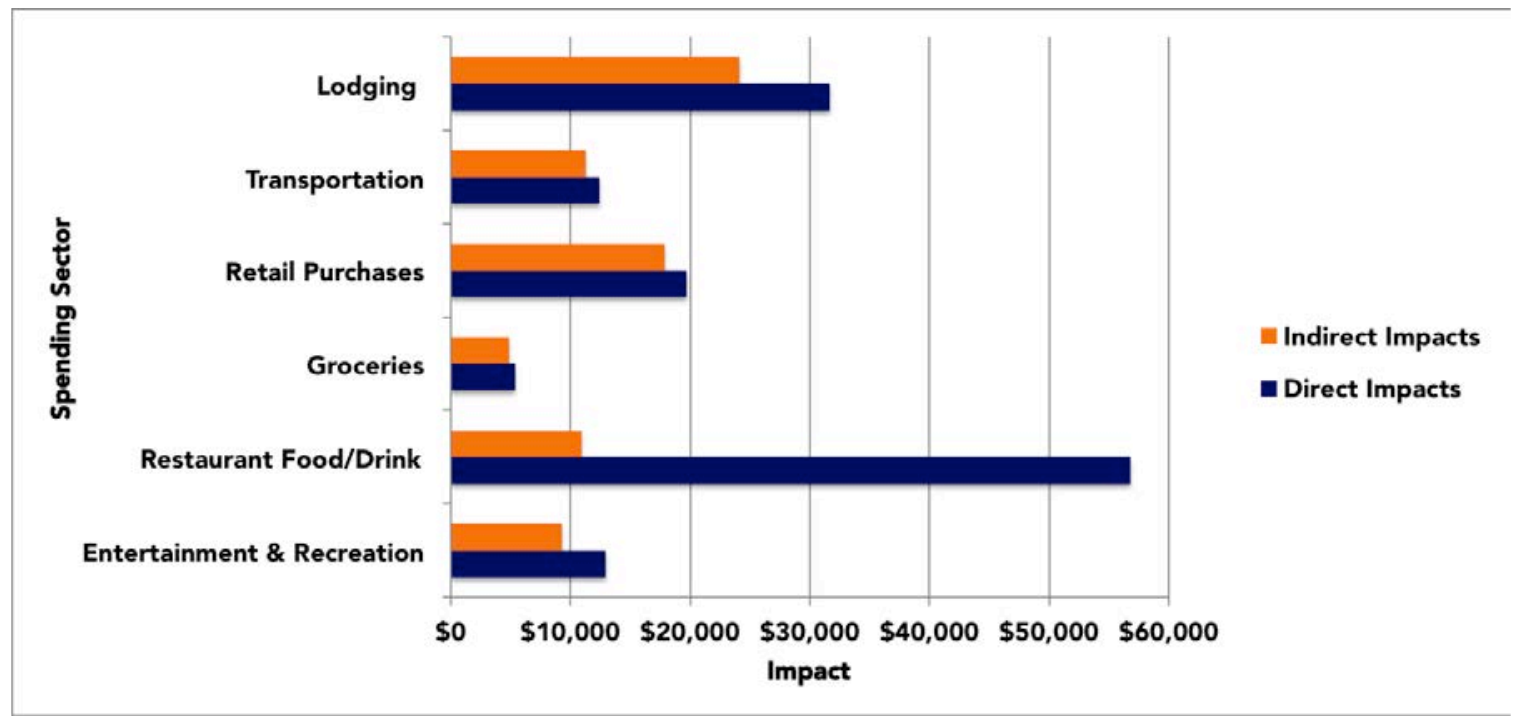

FIGURE 5.1 shows the direct and indirect impacts that visitor spending has on the corridor communities as a result of the byway's intrinsic qualities.

In conclusion, these findings support the fact that leisure and hospitality continue to be a driving force in the County's economy. Tourism is an important part of the region's financial vitality. By providing opportunities like the ability to access the North Coast Scenic Byway, the county will remain offering residents and visitors an unparalleled experience. Continuing to improve and enhance the Byway experience is a viable investment for both scenic protection and the economy. It does make cents to be scenic. 


\section{BIBLOGRAPHY}

Alabama Byways. (2010). History of the Program. Alabama Byways. Retrieved 5 February 2015, from http://www.alabamabyways.com/about/

American Society of Landscape Architects. (2015). ISSUE BRIEF: MAP-21 AND THE TRANSPORTATION ALTERNATIVES PROGRAM. Asla.org. Retrieved 8 February 2015, from http://www.asla.org/FederalGovernmentAffairs.aspx?id=34517

Board of Supervisors - County of San Luis Obispo. (1969). Resolution No. 69-356. San Luis Obispo, CA: San Luis Obispo County Board of Supervisors.

Board of Supervisors - San Luis Obispo County. (1999). County of San Luis Obispo's Corridor Protection Plan. San Luis Obispo, CA.

Bureau of Economic Analysis. (2014). Travel and tourism spending turned up in the second quarter of 2014 (1st ed., p. 5). Washington D.C.: Department of Commerce. Retrieved from http://www.bea.gov/newsreleases/industry/tourism/2014/pdf/tour214.pdf

Bureau of Labor Statistics. (2014). CPI Inflation Calculator. [online] Data.bls.gov. Available at: http://data.bls.gov/cgibin/cpicalc.pl?cost1=1.00\&year1=1966\&year2=2014 [Accessed 5 Jan. 2015].

California Highway Commission. (1925). California Highways. California Highway Commission.

Caltrans. (2008). Scenic Highway Guidelines (pp. 2-5). Sacramento, CA: Landscape Architecture Program.

Caltrans. (2014). Active Transportation Program (ATP). Dot.ca.gov. Retrieved 14 January 2015, from http://www.dot.ca.gov/hq/LocalPrograms/atp/

Central Coast Economic Forecast. (2012). 2012 central coast economic forecast. Los Angeles: Beacon Economics. 
Congressional Research Service (CRS). (1991). S.1490 - 102nd Congress (1991-1992): Scenic Byways Act of 1991 | Congress.gov | Library of Congress. Congress.gov. Retrieved 1 October 2014, from https://www.congress.gov/bill/102ndcongress/senate-bill/1490

Congressional Research Service (CRS). (1991). S.1490 - 102nd Congress (1991-1992): Scenic Byways Act of 1991 | Congress.gov | Library of Congress. Congress.gov. Retrieved 1 October 2014, from https://www.congress.gov/bill/102ndcongress/senate-bill/1490

Connor, J. (1966). A proposed program for scenic roads and parkways. Washington D.C.: U.S. Department of Commerce.

County of San Luis Obispo, (2007). Tax rate information and assessed valuations 20062007. San Luis Obispo: Auditor-Controller Office.

County of San Luis Obispo, (2013). Tax rate information and assessed valuations 20122013. San Luis Obispo: Auditor-Controller Office.

Dean Runyan Associates, (2014). California Travel Impacts. [online] Deanrunyan.com. Available at: http://www.deanrunyan.com/CATravellmpacts/CATravellmpacts.html [Accessed 20 Apr. 2014].

Department of Transportation. (1995). National Scenic Byways Program - Federal Register, Volume 60 Issue 96 (Thursday, May 18, 1995). Gpo.gov. Retrieved 14 January 2015, from http://www.gpo.gov/fdsys/pkg/FR-1995-05-18/html/9512211.htm

Ewing, R., M.R. King, Stephen W. Raudenbush, and O.J. Clemente. 2005. "Turning highways into main streets: Two innovations in planning methodology." Journal of the American Planning Association, 71(3): 269-282. 
Federal Highway Administration (FHWA), DOT. (1995). Federal Register / Vol. 60, No. 96 / Thursday, May 18, 1995 / Notices. www.fhwa.dot.gov. Retrieved 26 October 2014, from http://www.fhwa.dot.gov/hep/scenic_byways/fedreg.pdf

Federal Highway Administration (FHWA), DOT. (1995). National Scenic Byways Program (pp. 26759- 26762). Washington D.C.: Department of Transportation. Federal Highway Administration. (1991). An Analysis and Summary of the 1990 National Scenic Byways Study Inventory. Washington, DC: U.S. Department of Transportation.

Federal Highway Administration. (2011). TEA-21 - A Summary - Protecting Our Environment.Fhwa.dot.gov. Retrieved 8 February 2015, from http://www.fhwa.dot.gov/Tea21/sumenvir.htm

Google Maps. (2011). [San Simeon, California] [Street map].

Historic Photos were generously provided by the San Luis Obispo County Historical Center

Ivan. (2006). Morro Bay Docks. [online] Commons.wikimedia.org. Available at: http://commons.wikimedia.org/wiki/File:Morro_Bay_Docks.jpg JBG Consulting, LLC, (2014). Economic Appraisal: The Mid-Coast of San Luis Obispo County, CA Estero Bay Scenic Byway Trail. San Luis Obispo, CA, pp.1-29. Jensen, G. (2013). America's Byways Pay Off in Authentic Experiences, But How About Dollars? - Vol. 76 - No. 4 - Public Roads. Fhwa.dot.gov. Retrieved 13 February 2015, from http://www.fhwa.dot.gov/publications/publicroads/13janfeb/05.cfm Johnson, L. (1965, February). "Special Message to the Congress on Conservation and Restoration of Natural Beauty. Congress, Washington D.C. 25 Oct. 2014.

Lathrop, Andrew. A Brief History of Mission San Luis Obispo De Tolosa. 1996. http://198.188.248.11/2982/history.htm

Liebgold, D. (2014). Trisha and Asher at Fiscalini Ranch. [online] Flickr. Available at: 
http://www.flickr.com/photos/dan-liebgold/4311108804/

Long Range Interpretive Plan, Monterey Bay Sanctuary Scenic Trail, Monterey Bay National Marine Sanctuary

Morro Bay Sun Newspaper. (1968). Commission Gets Scenic Hwy Pitch.

National Transportation Library. (2014). Intermodal Surface Transportation Efficiency Act of 1991 - Summary. Ntl.bts.gov. Retrieved 13 September 2014, from http://ntl.bts.gov/DOCS/ste.html

O'Brien, B. (1999). Our National Parks and the Search for Sustainability. Austin: University of Texas Press.

Paul Daniel Marriott \& Associates. (1995). Corridor Management Plans. Historicroads.org. Retrieved 26 October 2014, from http://www.historicroads.org/sub4_3.htm

PG\&E, (2014). Electric undergrounding program. [online] Pge.com. Available at: http://www.pge.com/myhome/addservices/electricundergrounding/

San Juan Islands Visitors Bureau. (2011). Scenic byways corridor management plan. [online] Visitsanjuans.com. Available at: http://www.visitsanjuans.com/scenicbyway/management-plan [Accessed 14 Apr. 2014].

San Luis Obispo Council of Governments (SLOCOG). (2015). SLOCOG - Project Search. Transinfo.slocog.org. Retrieved 15 February 2015, from http://transinfo.slocog.org/Default.asp?search_str=\&LEAD_AGENCY=\&project_t ype $=H w y \% 3 A+H w y+1 \% 7 C H w y \% 3 A+H w y+1 \&$ transit_system=\&ROUTE=\&IS_FR OM_FULL=True

San Luis Obispo Council of Governments (SLOCOG). (2015). SLOCOG - Project Search.Transinfo.slocog.org. Retrieved 15 February 2015. 
San Luis Obispo Council of Governments. (2001). Staff Report - State Route 1 Federal Highway Administration Corridor Management Plan Grant. San Luis Obispo, CA. San Luis Obispo County Parks Division. Elfin Forest Natural Area Resource Management Plan. August 1997.

San Luis Obispo Economic Vitality Corporation, (2008). SLO County Tourism Study. [online] SLO Tourism Report. Available at: http://www.sloevc.org/files/SLO\%20County\%20Tourism\%20Report_2008\%20(v_ 2).pdf [Accessed 3 Feb. 2014].

Scenic America. (2006). Issues - Scenic Byways. Scenic.org. Retrieved 7 February 2015, from http://www.scenic.org/issues/scenic-byways

Scenic America. (2013). Issues - Scenic Byways. Scenic.org. Retrieved 7 February 2015, from http://www.scenic.org/issues/scenic-byways

Sierra Club - Santa Lucia Chapter. Morros (Nine Sisters) Preservation Fund. http://santalucia.sierraclub.org/morros.html

Sierra Club San Luis Obispo. One Earth, One Chance. Montana De Oro State Park. http://santalucia.sierraclub.org/mntdeoro.html

Smith, C. and Olson, E. (1991). Economic Analysis of Scenic Byways in lowa, Kansas, Missouri, and Nebraska, final technical report. [online] Ctre.iastate.edu. Available at: http://www.ctre.iastate.edu/research/detail.cfm?projectID=15 [Accessed 8 Apr. 2014].

State of California Department of Public Works. (1968). Scenic Highway Designation Procedures. Sacramento, CA.

State of California Department of Transportation. (1998). Route 1 Scenic Highway Resolution Package. San Luis Obispo, CA.

Sutter, L. (1999). Scenic Highway becomes official. The Tribune. 
Tanner, K. (2015). Hearst Castle visits rise along with SLO County's fortunes | The Cambrian | SanLuisObispo. Sanluisobispo.com. Retrieved 7 February 2015, from http://www.sanluisobispo.com/2015/01/21/3452872_hearst-castle-visits-risealong.html

The National Conference on State Parks. (1965). THE WHITE HOUSE MESSAGE ON NATURAL BEAUTY. Trends In National Parks, 2(2), 4-10.

The National Parks: America's Best Idea. (2009). Washington D.C.

Thomas - Library of Congress. (1991). Bill Text 102nd Congress (1991-1992)

H.R.2950.ENR.Thomas.Ioc.gov. Retrieved 26 October 2014, from http://thomas.loc.gov/cgi-bin/query/F?c102:1:./temp/ c102nRjjaP:e276605

United States Bureau of Land Management. Piedras Blancas Light Station Restoration Project Report. January 2002.

United States Department of the Interior, Bureau of Land Management, http://www.blm.gov/ca/pa/coastal_monument/

United States Department of Transportation. (2002). U.S. transportation secretary mineta names 36 new national scenic byways, all-american roads (6/13/02). [online] Fhwa.dot.gov. Available at: http://www.fhwa.dot.gov/pressroom/fhwa0227.cfm [Accessed 3 Jun. 2014]. United States Forest Service. Southern California National Forests Plan Notice of Intent. Los Padres District. 2002.

US DOT Federal Highway Administration. (2013). History of Scenic Road Programs General Highway History - Highway History - Federal Highway Administration. Fhwa.dot.gov. Retrieved 7 February 2015, from http://www.fhwa.dot.gov/infrastructure/scenichistory.cfm

Works Progress Administration. (1939). California: A Guide to the Golden State in the 1930s (pp. 340-347). 
APPENDIX: ROUTE 1 SAN LUIS OBISPO NORTH COAST SCENIC BYWAY CORRIDOR PLAN UPDATE 

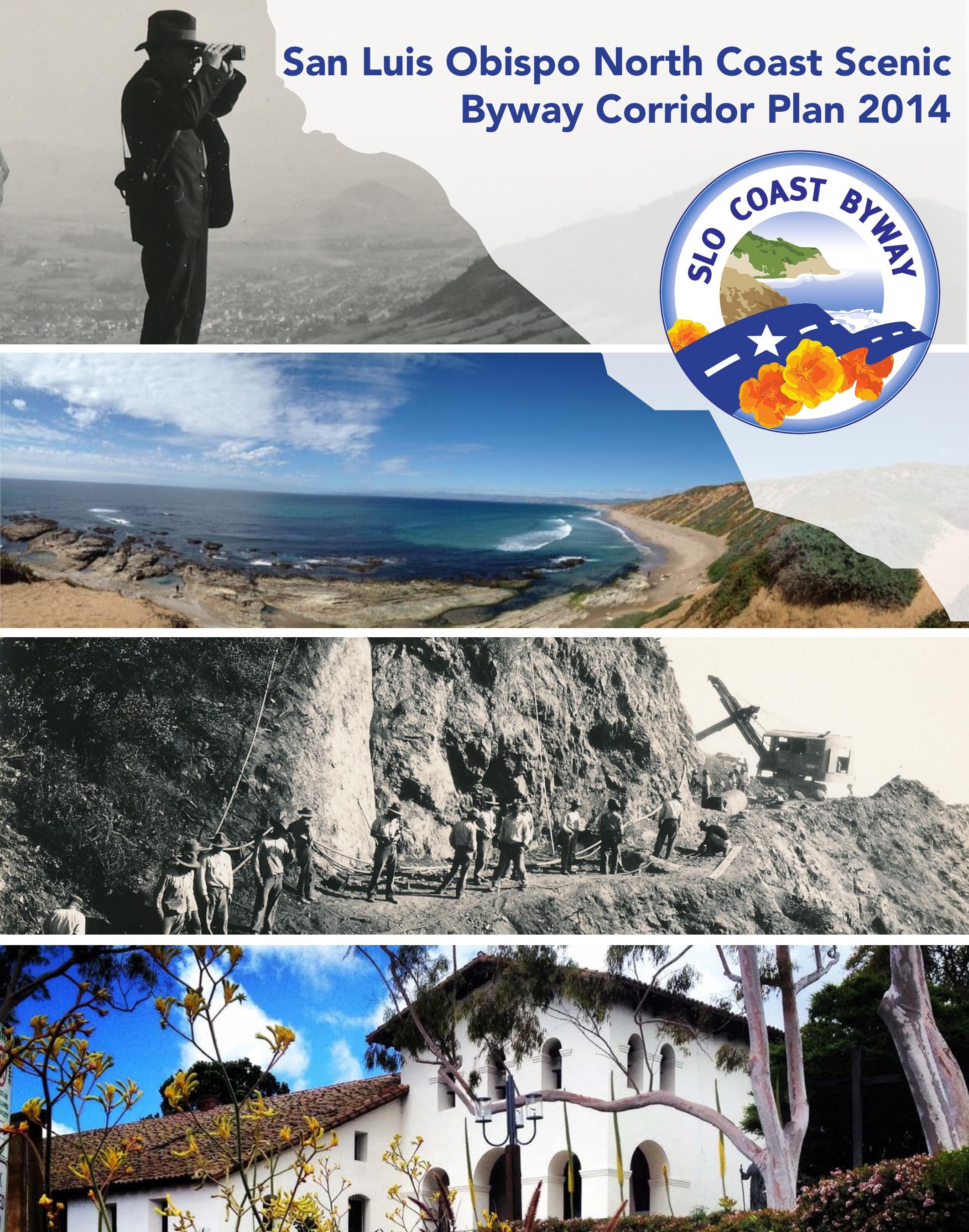


\section{The San Luis Obispo Council Of Governments Membership}

The San Luis Obispo Council of Governments (SLOCOG) is an area wide planning and programming agency for issues of area wide concern. SLOCOG is also the state-designated Metropolitan Planning Organization (MPO), the Census Data Affiliate, and the state-designated Regional Transportation Planning Agency (RTPA) for the San Luis Obispo region. As the RTPA, SLOCOG is responsible for administering the Transportation Development Act (TDA) in the San Luis Obispo region. Member Agencies are listed below with their appointed representatives.

\section{SLOCOG Board Members (January 2014)}

President Shelly Higginbotham, Mayor, City of Pismo Beach

Vice President.

San Luis Obispo County, District 1. ...Debbie Arnold, Supervisor, San Luis Obispo County, District 5

San Luis Obispo County, District 2.

San Luis Obispo County, District 3.

Frank Mecham, Supervisor

San Luis Obispo County, District 4. Bruce Gibson, Supervisor

City of Arroyo Grande.

City of Atascadero.

Adam Hill, Supervisor

City of Grover Beach.

Caren Ray, Supervisor

City of Morro Bay.

Tony Ferrara, Mayor

.Tom O'Malley, Mayor

City of Paso Robles

Debbie Peterson, Mayor

City of San Luis Obispo.

Caltrans District 5 (Ex-Officio). Jamie Irons, Mayor Fred Strong, Council Member ..Jan Howell Marx, Mayor . Timothy Gubbins, District 5 Director

\section{SLOCOG Byway Plan Update Team}

Project Manager.

Sara Sanders

Executive Director.

Ronald L. De Carli

Programming Director.

TransportationPlanner.

Transportation Planner. Richard Murphy

Transportation Planner. Geiska Velasquez

Transportation Planner. .Tim Gillham

Administrative Services Officer

Jessica Berry

Administrative Services Officer.

.Geoffrey Chiapella Sue Hall

Lori Kramer

\section{Scenic Byway Committee}

Caltrans.

Bob Carr

Caltrans.....

County of San Luis Obispo

County of San Luis Obispo.

Cayucos Advisory Council.....

Cambria Chamber of Commerce

City of San Luis Obispo.

City of Morro Bay.....

City of Morro Bay...

North Coast Advisory Council

North Coast Advisory Council.

San Simeon CSD.

San Simeon CSD.

California Department of Parks and Recreation

California Department of Parks and Recreation

SLO Regional Transit Authority (RTA).

Adam Fukushima Shaun Cooper Elizabeth Kavanaugh ....John Carsel Mel McColloch .Peggy Mandeville Barry Rands Joe Woods Claudia Harmon Worthen Bruce Fosdike Charlie Grace Renee Lundy .Doug Barker .Cara O'Brian Aimee Wyatt 
INTRODUCTION

CHAPTER 1: NORTH COAST SCENIC BYWAY CORRIDOR

Existing Conditions

Corridor Communities

Intrinsic Qualities

\section{CHAPTER 2 - BYWAY VISION AND PLANNED IMPROVEMENTS}

Byway Vision.

Programs

Interpretation

$31-36$

Capital Projects

37-38

Safety \& Operational Projects

Scenic Viewshed Protection Projects

Improvement Projects

Improvement Maps

\section{CHAPTER 3 - ADMINISTRATION}

Plan Update Process

Funding

Technical Assistance.

\section{APPENDICES}
A) The SLO North Coast Scenic Byway Interpretive Signage Plan
B) Summary of framework of protections
C) County of San Luis Obispo Scenic Highway Corridor Protection Plan
D) San Luis Obispo County Coastal Plan Policies, Environmentally sensitive habitats
E) City of Morro Bay Scenic Highway corridor protection plan
F) Inventory of Overlooks
G) Economic Analysis Inputs and Assumptions
H) Public Comment 


\section{EXECUTIVE SUMMARY}

Route 1 between the City of San Luis Obispo and the Monterey County line was designated an All-American Road by the Federal Highway Administration on August 8, 2003. This level of scenic designation is reserved for routes that possess nationally significant resources (intrinsic qualities) and is the highest scenic designation of any road or highway in the nation. The Route 1 San Luis Obispo North Coast Scenic Byway Corridor was designated as a result of the scenic, natural, recreational, and historical qualities that draw visitors from around the country and around the world. Coupled with the Big Sur Coast All-American Road, which begins at the San Luis Obispo/Monterey County Line and courses along the rugged coastline north through Big Sur to Monterey, the highway provides one of the best traveling experiences in the world.

The Route 1 Scenic Byway Corridor Plan (BCP) is intended to identify programs that will maintain and improve the opportunities and experiences of traveling in the corridor. It also identifies the resources that make the Byway extraordinary and includes how the corridor is being protected and enhanced. The plan attempts to bring together improvement plans of the different regulatory and programming agencies in the corridor, including San Luis Obispo County, the City of Morro Bay, Caltrans, California Department of Parks and Recreation, Bureau of Land Management, California Coastal Conservancy, California Coastal Commission, and the San Luis Obispo Council of Governments (SLOCOG). These agencies have developed plans that are consistent with their missions through extensive public outreach and input.

This BCP update focused on refining the plan's comprehensiveness, document layout, mapping, and the economic benefits provided by the corridor.

There are four chapters of the Byway Corridor Plan:

1. North Coast Scenic Byway Corridor

2. Byway Vision and Improvements

3. Plan Administration and Project Implementation

4. Economic Benefits

The plan does not introduce additional land use regulatory restrictions or policies. It is based on adopted strategies to protect and enhance the corridor's qualities, which were discussed at length during development of the original plan. In addition to the locally adopted plans that address land use policies and circulation of the local transportation system, the plan identifies many of the improvements that are planned for the corridor by SLOCOG and the State. These projects are primarily associated with maintaining the highway's current configuration with improvements to enhance access and aesthetics, maintain operations, and improve how the highway interrelates with the communities it passes through.

Due the removal of grant funding from the National Scenic Byway Program, an economic benefit analysis was performed. The analysis demonstrates the importance of funding scenic projects along the Byway in an increasingly competitive transportation funding environment.

As a result of this process, two key findings were apparent. The first key finding was to encourage local agencies to adopt policies which support the goals and objectives of the Scenic Byway Corridor Plan. The second finding was to consider the possibility of pursuing scenic designation south of the City San Luis Obispo along Route 1, which would require applying for state scenic designation and then, if resources allow, pursue federal designation. 
Winding through San Luis Obispo County on California's Central Coast is a section of State Route 1 that provides a truly remarkable experience to travelers. Highway 1 between the city limits of San Luis Obispo and the northern San Luis Obispo County line is one of the most relaxing and beautiful in all of California.

The highway stretches through valleys, along coastal ranges and the Pacific Ocean, into Monterey pine forests, on top of coastal terraces, and finally along sheer granite cliffs. The journey offers travelers an unsurpassed experience of California's coastline in a nearly pristine state. The corridor boasts both natural and human elements that give it an appeal all its own.

It is the objective of this plan to identify how this corridor will retain its irreplaceable scenic resources, while enhancing the communities and facilities within it for its residents and travelers of the highway for generations to come.

Following the designation of Highway 1 as a State Scenic Highway in 1999, SLOCOG initiated the process of pursuing the inclusion of the highway into the Federal Highway Administration's (FHWA) National Scenic Byways program. The program designates those highways that exhibit qualities that distinguish the corridor from others around the state and country as either a "National Scenic Byway" or an "All-American Road."

At a minimum, National Scenic Byways are those highways that have at least one quality significant to a two state region. The more selective of the two types of national byways, the "All-American Road" designation, is reserved for those highways that are "destinations unto themselves," possess at least two qualities that are significant on a national level, and one that is unparalleled in the country.

Designation into the program requires three things: existing Officially Designated State Scenic Highway status, the highway corridor meeting one of the two definitions identified in the preceding paragraph, and a plan that identifies how the corridor's special attributes will be protected and enhanced. This plan fulfills the last of these requirements. The Byway Corridor Plan (BCP) was first adopted in February 2002. It was structured largely to meet the requirements of the Scenic Byways Program.

While the National Scenic Byways program was completely eliminated under MAP-21, some scenic byway type projects are eligible under category 4 of TAP which will be explained in the funding section. Eligible projects under the Surface Transportation Program and the Transportation Alternatives Program that may have previously been eligible as part of the National Scenic Byways Program include the construction of turnouts, overlooks, and viewing areas; historic preservation and rehabilitation of historic transportation facilities related to a byway; and bicycle and pedestrian facilities along a byway. Support through a Scenic Byway Corridor Plan will increase the competitiveness of projects competing for discretionary funding under new federal MAP21 and State sources.

\section{Changes}

The 2014 BCP update, while still meeting the requirements of the original National Scenic Byway program, is organized in a manner that is more tailored to its actual use as a regional planning document

\section{Changes to the BCP for the 2014 update} were primarily meant to:

- Streamline plan's organization

- Increase focus on Economic Benefits of Scenic Designation

- Highlight priorities for short-mid term implementation

- Highlight projects and programs completed

- Make maps more informative and useful 


\section{Primary Components}

\section{The Byway Corridor Plan has four primary} components:

- Chapter One of the plan discusses the Corridor and Scenic Byways Program. It provides a summary of Highway 1 , the communities in the corridor, and a description of the qualities of the corridor that make the area unique.

- Chapter Two identifies the Byway Vision, Policies, Goals and Programs for the corridor.

- Chapter Three focuses on the plan administration.

- Chapter Four provides an economic analysis of the corridor designation and planned improvements for benefit to the Byway communities and the county in general.

\section{Regulatory Implications}

The plan does not include any additional regulations to land use. The regulatory framework for protecting the corridor's scenic resources is included in existing local plans, and state and federal environmental laws. This plan is intended solely to identify how these resources are protected in this existing framework, and provide a plan to further enhance Highway 1 in the area by providing betterments including landscaping, billboard removal, roadway and other visual upgrades.

\section{Planning Process Overview}

This update of the $\mathrm{BCP}$ continued to utilize the Scenic Byway Advisory Committee (SBAC) as the primary guiding body for byway planning. In December 2005 the SLOCOG board authorized the alteration of the SBAC to be a two-tiered committee composed of voting and non-voting members. The rationale for the change was due to the very large group of stakeholders the committee enjoys. The committee had grown to a size that began to result in low participation and response rates to committee meetings and requests for feedback. Since the changing of the committee structure, response rates and participation by the voting membership has improved and been vital in development of the plan.

The SBAC provided recommendations to staff on project priorities and on the plan's content. The groups held a number of meetings and reviewed and commented on the Administrative Draft document.

The composition of the committee includes:

\section{STEERING COMMITTEE (Voting Members)}

- California Department of Transportation (Caltrans)

- City of San Luis Obispo

- County of San Luis Obispo

- City of Morro Bay

- Cayucos Advisory Council

- North Coast Advisory Council

- Cambria Community Service District

- San Simeon Community Service District

- California Department of Parks and Recreation

- San Luis Obispo Regional Transit Authority 


\section{KEY STAKEHOLDERS (Non-Voting Members)}

- American Land Conservancy

- Big Sur All-American Road Byway Committee

- Bureau of Land Management

- California Polytechnic State University

- Cambria Greenspace

- Cambria Historical Society

- Cambria Parks, Recreation and Open Space Commission

- Cayucos Chamber of Commerce

- Cayucos Land Conservancy

- Coastal Commission

- Coastal Conservancy

- Congresswoman Capps

- Cuesta College

- Economic Vitality Corporation

- Environmental Center for SLO County

- Friends of the Elephant Seals

- Hearst Ranch

- Hearst Ranch

- Morro Bay Beautiful

- Morro Bay Chamber of Commerce

- National Byways Resource Center

- National Estuary Program

- Ranchers of San Luis Obispo

- San Luis Obispo Air Pollution Control District

- San Luis Obispo Bicycle Coalition

- San Luis Obispo Business Improvement District

- San Luis Obispo Chamber of Commerce

- San Simeon Chamber of Commerce

- SLO County Visitors Conference Bureau

- SLOCOG CTAC Representative

- Surf Rider

- Ventana Wilderness Alliance 


\section{CHAPTER 1 Y ${ }^{6}$ \%}

\section{BYWAY CORRIDOR OVERVIEW}

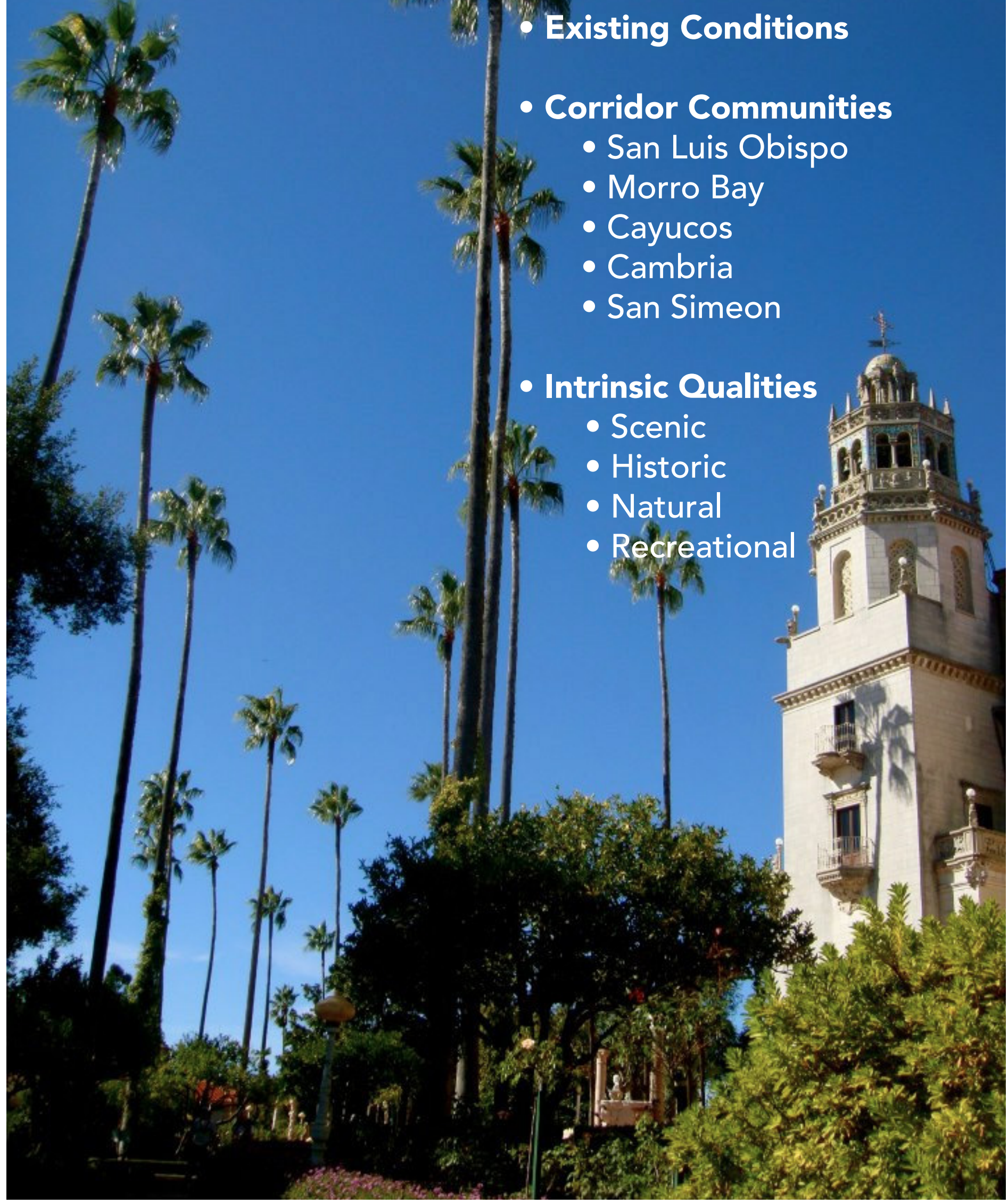




\section{EXISTING CONDITIONS}

The subject area of Highway 1 is a two to four lane rural arterial extending approximately 58 miles between Highland Drive in the City of San Luis Obispo and the Monterey County line. The highway is a four-lane freeway expressway from San Luis Obispo to just north of Cayucos, where it becomes a conventional two lane rural highway to the Monterey County line. The highway continues north of SLO County for 72 miles along the Big Sur All-American Road to Carmel, providing for a remarkable 130-mile adventure.

The route serves both regional and interregional traffic with Department of Transportation (Caltrans) being the sole operator and maintainer of the facility. Caltrans is also responsible for ensuring the safety of the facility, which includes such improvements such as median barriers, channelizations, shoulders and bridge widening. Much of the traffic is tourist in nature, although commute traffic is prevalent between San Luis Obispo and Cambria. There are a number of major traffic generators on the route including Hearst Castle, Cuesta Community College, California Men's Colony (a medium security federal correctional facility) and California Polytechnic State University in San Luis Obispo, as well as the communities along the route. The highway has an overall safety record that is generally better than comparable highways throughout the State of California.

The highway is the primary north/south arterial through the North Coast Planning Area of San Luis Obispo County. The highway is specifically restricted to be maintained as a two-lane highway north of Cayucos by the California Coastal Act (passing lanes and channelization are allowable under certain parameters). There are five grade-separated interchanges through the length of the corridor: three in Morro Bay and two in Cayucos.

Many intersections along the corridor are anticipated to meet warrants for signalization in the future. Operational improvements, such as turn channelization, acceleration/deceleration lanes, and potentially a passing lane between Cayucos and
Cambria are measures that will be considered to respond to the anticipated increase in vehicle trips. The California Coastal Commission does not permit widening of highway 1 to four lanes in the byway corridor.

The highway has created challenges for pedestrian and bicycle access crossing the highway to and from the coast. This access is especially critical in the urbanized communities because of the desire to have enhanced coastal access for people on foot and on bikes. All of the communities in the corridor have placed a high priority on the enhancement of coastal access. 


\section{North Coast Scenic Byway Corridor}

Monterey County

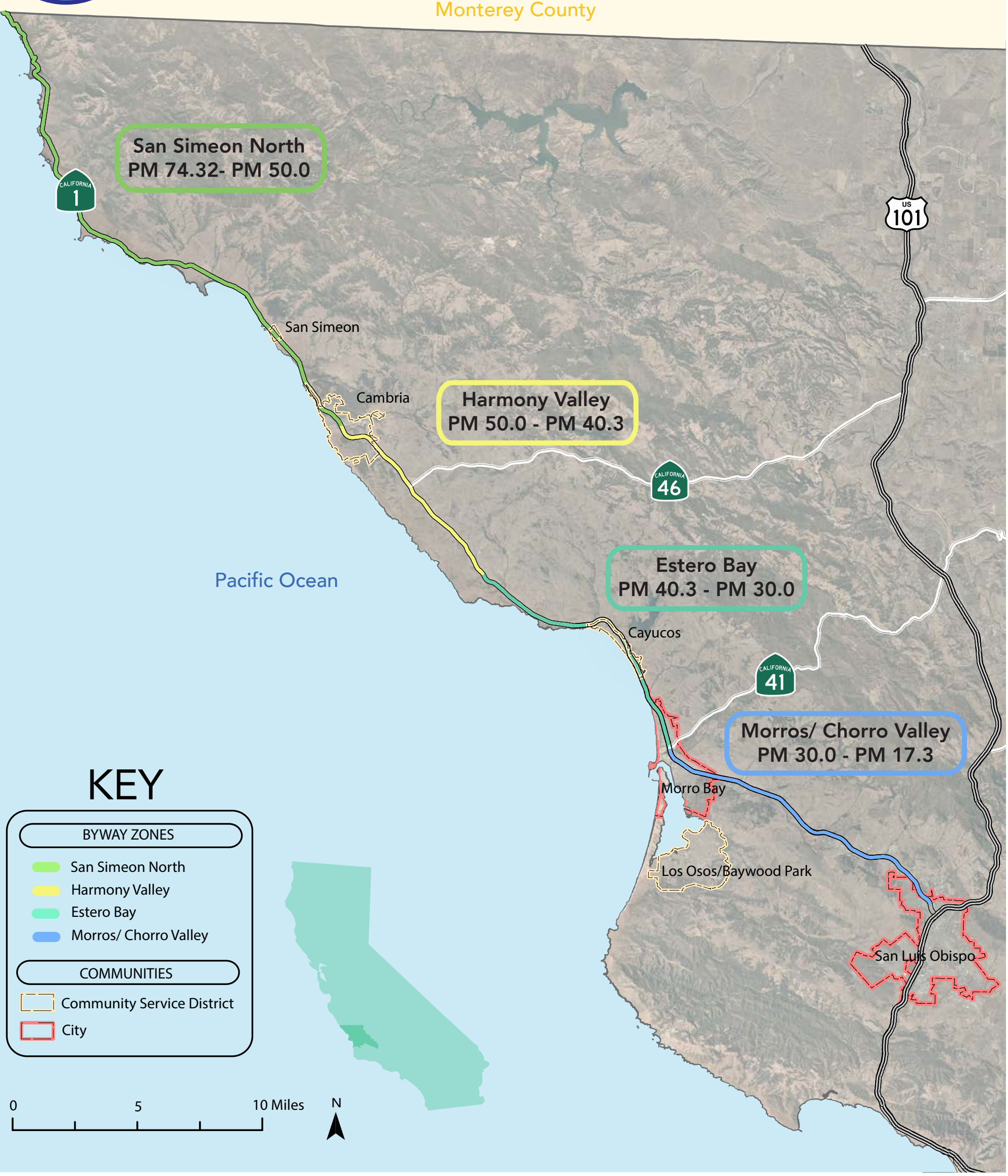


The North Coast Region consists of two of the County of San Luis Obispo's planning areas, Estero and North Coast. It is largely considered the county's most scenic and pristine natural area, which draws tourists from around the state, the country and the world. The beauty of the corridor is enhanced by a number of human and natural destinations. Some of the most popular attractions include Hearst Castle, Hearst San Simeon State Park, Cambria, Cayucos, Morro Bay, and Montaña De Oro State Park. Because of its attraction as a tourist destination, the area has distinct transportation demands.

State Route (S.R.) 46 connects the North Coast with the communities of the North County Region. With its vistas of the Pacific Ocean and the Santa Lucia mountains, the highway is a fantastic scenic corridor in its own right. This corridor has an expanding wine industry that also attracts travelers from other parts of the state, which increases the potential for traffic impacts. S.R. $46 \mathrm{~W}$ has additional capacity to handle the growth with identified improvements limited to increased channelization. State Route $41 \mathrm{~W}$ is similar to S.R. $46 \mathrm{~W}$ in that it connects the north coast region with the Salinas River Valley. However, S.R. 41 traverses more mountainous terrain, limiting the type of improvements that can be accommodated such as additional turn-channelization and passing lanes.

The southern area of this sub-region consists of three communities: Los Osos, Morro Bay (incorporated) and Cayucos. Bordered by Estero Bay and the Morro Bay Estuary, these communities' economies are fueled primarily by income from local entrepreneurial efforts, visitor-serving businesses, and jobs located in San Luis Obispo and southern San Luis Obispo County. Los Osos and Cayucos are "bedroom communities," since roughly 75 percent of their workers commute to jobs in other communities. Although the City of Morro Bay generates some employment for local residents (and contributes significantly to the area's economy), a large percentage of local workers also find employment in the San Luis Obispo area.

Los Osos and Cayucos have businesses that provide retail and service uses for local residents, but lack major employers, large-scale manufacturing and industril uses. In Los Osos there are currently few visitor-serving businesses. In Cayucos, visitor-serving business is the primary source of employment. In both communities, the commercial sectors are currently under-developed compared to nearby incorporated cities, and residents spend much of their income outside of the Estero Bay Area. In the rural areas outside of Los Osos, Morro Bay, and Cayucos, most economic activity is related to agriculture.

\section{Key San Luis Obispo County policies affecting} growth and resource management in the North

\section{Coast Planning area include:}

- Maintain agriculture \& the rural character of the area.

- Permanently protect the agricultural, open space and scenic resources of the Morros. The Morros are a chain of volcanic peaks and hills between San Luis Obispo and Morro Bay.

- Prevent further urban and suburban encroachment into the Los Osos and Chorro Valleys in order to maintain valuable agricultural and open space resources.

- Manage the watershed of the Morro Bay estuary so that the estuary is a clean, healthy, functioning ecosystem that harbors a diversity of wildlife.

- Areas outside of Cambria, San Simeon, and the Hearst Castle staging areas should be maintained as agriculture, open space, low-density residential, or recreation to preserve the intrinsic qualities of the communities.

- Preserve urban reserve lines.

- Preserve neighborhood characteristics with sense of scale, pedestrian areas, landscaping, open areas, and other amenities.

- Encourage affordable housing.

- Require developments and long-range plans to create a jobs/housing balance.

- Establish an efficient circulation system and pattern of land uses that minimize the number of automobile trips.

- Encourage alternatives to single occupant automobile travel, such as pedestrian and bicycle travel, transit, carpooling, and telecommuting. At the same time, accommodate automobile transportation. 

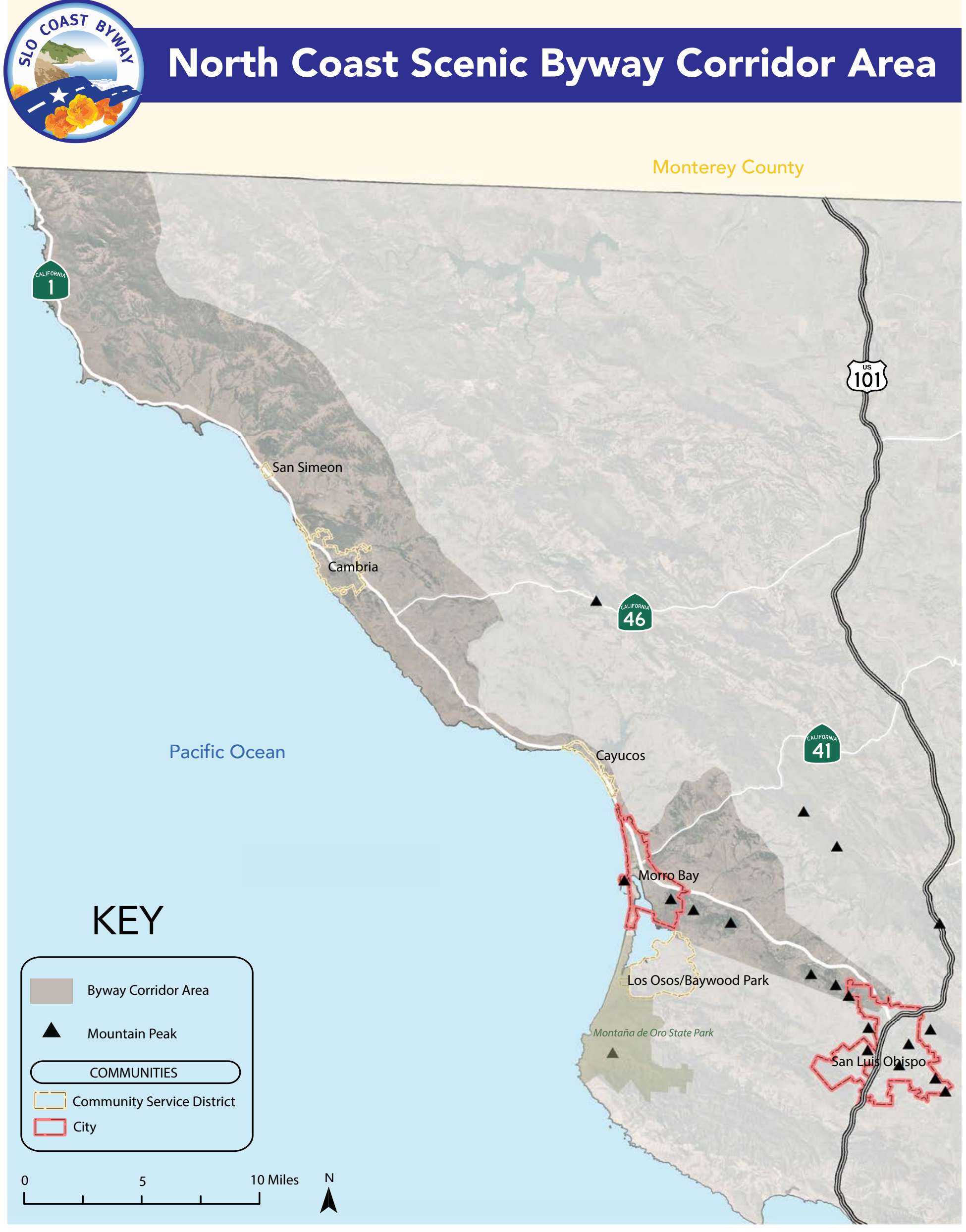


\section{CORRIDOR COMMUNITIES}

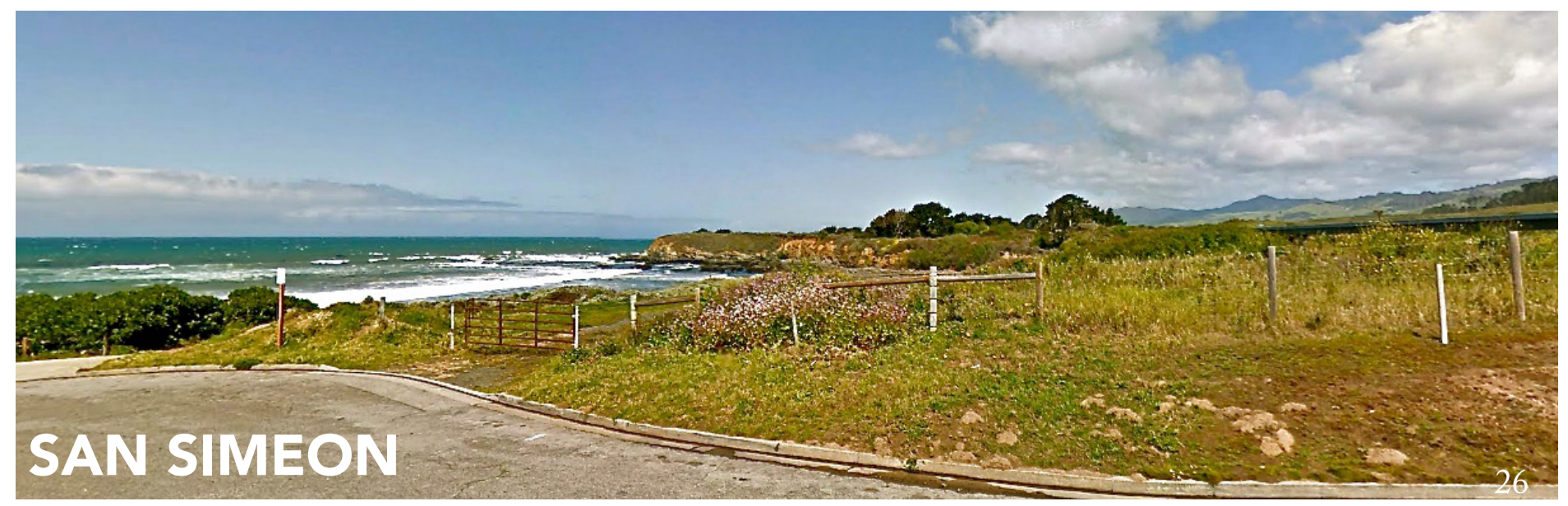

San Simeon, a community of 462 residents (2010), sits on the Coastal Edge of Highway 1. The San Simeon Community Services District (CSD) is responsible for water and sewer service, lights, and roads. In addition to the community's permanent residents, the CSD is host to a large hotel village (689 rooms) that serves the needs of travelers. Many of San Luis Obispo's north coast attractions, such as Hearst Castle, Ragged Point, and the Elephant seals at Piedras Blancas rookery, are within a short trip along Highway 1 from San Simeon.

Within San Simeon CSD, there are opportunities to improve access and aesthetics. The current pedestrian walkway crossing from the east to the west side of the highway is in need of increased visibility, signage, and maintenance. The two beach access points are also in need of repair and maintenance due to erosion and deterioration. Increased landscaping enhancements and fencing along the corridor would also enhance the community.

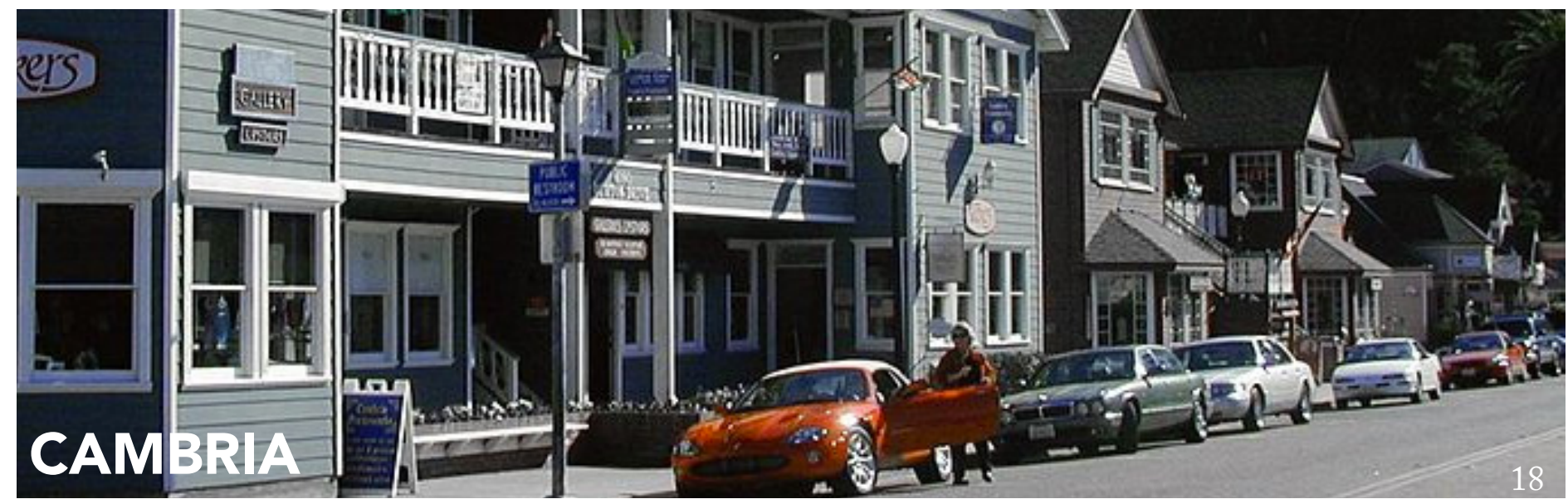

Cambria, a community of 6,032 residents (2010), has a distinct downtown core and a desire to maintain a small village character. There has been an effort in recent years to create better connectivity between the two distinct sections of downtown. A lack of downtown parking, the desire to minimize traffic impacts, and limitations in expansion potential have prompted the community to advocate alternative transportation modes, such as a downtown trolley, and build associated infrastructure, such as bike and pedestrian improvements. 


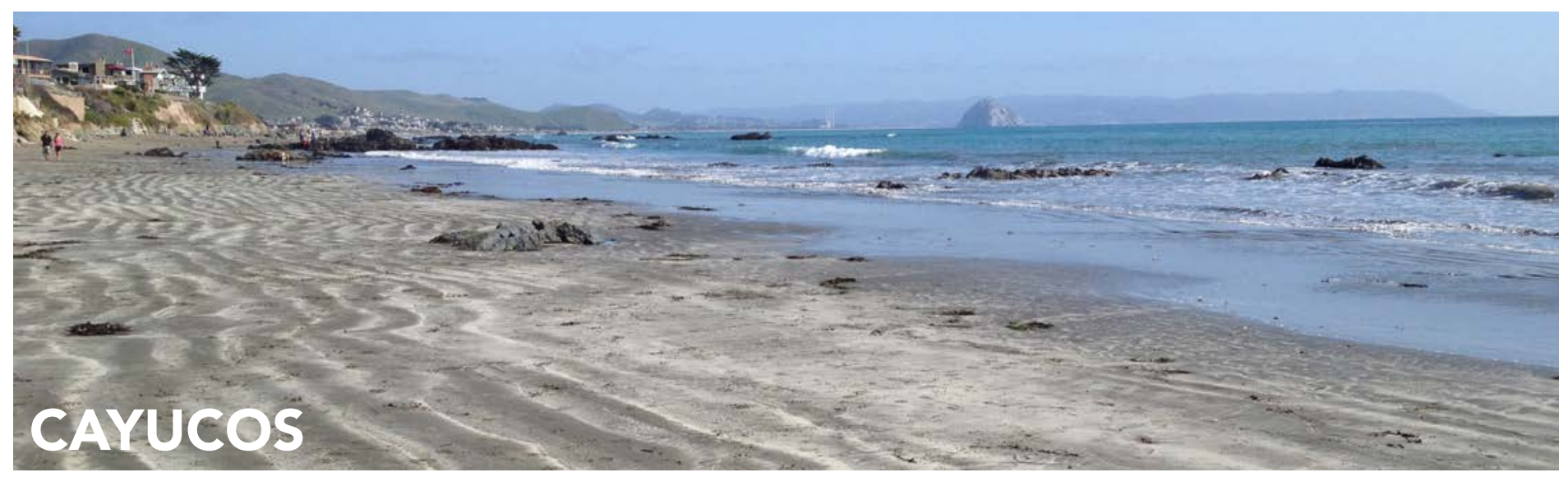

Cayucos is a small coastal community of approximately 2,600 residents (2010). The community is known for its status as the last of California funky little beach towns. It is isolated from adjoining Morro Bay with no access other than via Highway 1. The town has two interchanges, one signalized intersection and a number of other stop-controlled at-grade intersections. Some of the community's primary goals are improving downtown parking and streetscape enhancements and improving the safety of intersections with Highway 1 . These goals are being achieved through the addition of coastal access stairways, a downtown boardwalk, and increased bicycle lanes.

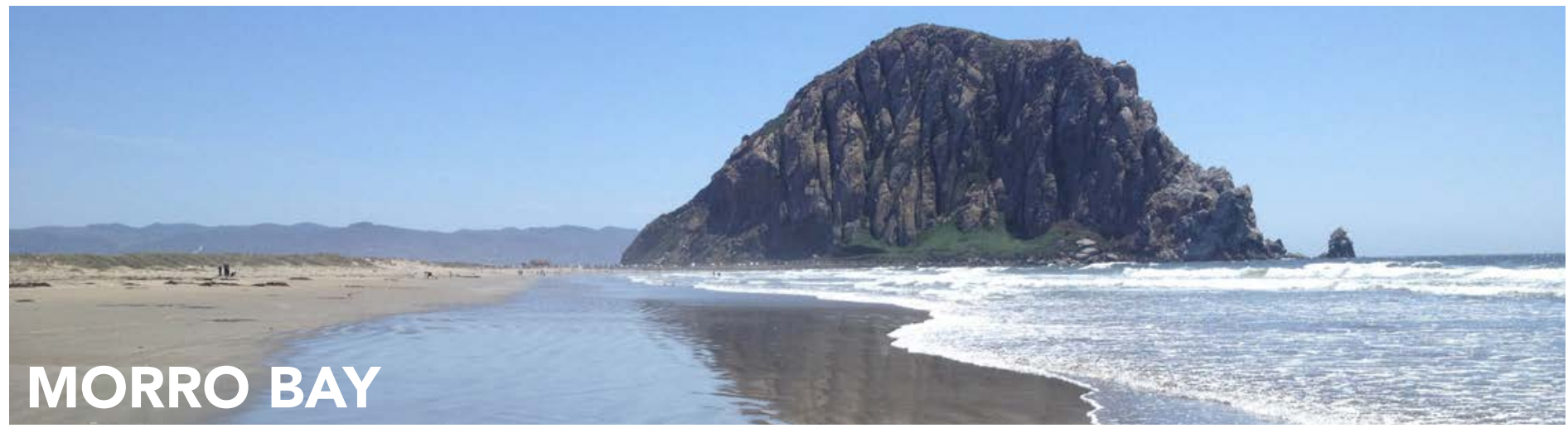

The City of Morro Bay is the only incorporated city in the Byway corridor (Byway begins at the City limit line of San Luis Obispo). The City's population of 10,234 is expected to rise at a rate of .64 percent over the next five years to 10,570 residents. It is a seaside community and popular tourist destination. Its history is steeped in its fishing industry, which it is trying to preserve and protect. Morro Rock, the city's iconic Historic Landmark, dominates the vistas of Byway travelers from south and north. The city's downtown, bayside embarcadero, access to the bay and ocean, and the adjacent Morro Bay State Park draw visitors year-round.

As traffic volumes continue to increase, Highway 1 has become a barrier between west and east Morro Bay. Safe crossing from one side of Morro Bay to the other has been, and continues to remain, a concern for many residents of the community. This issue is one of a number concerning Highway 1 that the city has recognized as a problem that needs to be addressed. The North Main Specific Plan was developed in 1989 to address what the Morro Bay community perceives as an area in need of improvements. The plan sets a strategy for improving the northern portion of the City, east of Highway 1. Main Street is a parallel route with Class II bicycle lanes to Highway 1 and a primary north-south arterial. Because of its proximity and visibility to Highway 1, the area has great potential to attract many of those traveling on the byway. The Specific Plan identifies a number of projects intended to enhance the appearance and increase accessibility of this area.

Planned enhancements to the area include landscaping, improved fencing, community gateway enhancements, bike lanes, and pavement treatments to ramps and crosswalks. These improvements will enhance the area's character, improve cross highway non-motorized access, soften the urban landscape, reduce the visual impact of Highway 1 to the community and provide an appeal for Highway 1 travelers and the community's residents. Though some of these improvements have been implemented, many more are yet to be realized. 


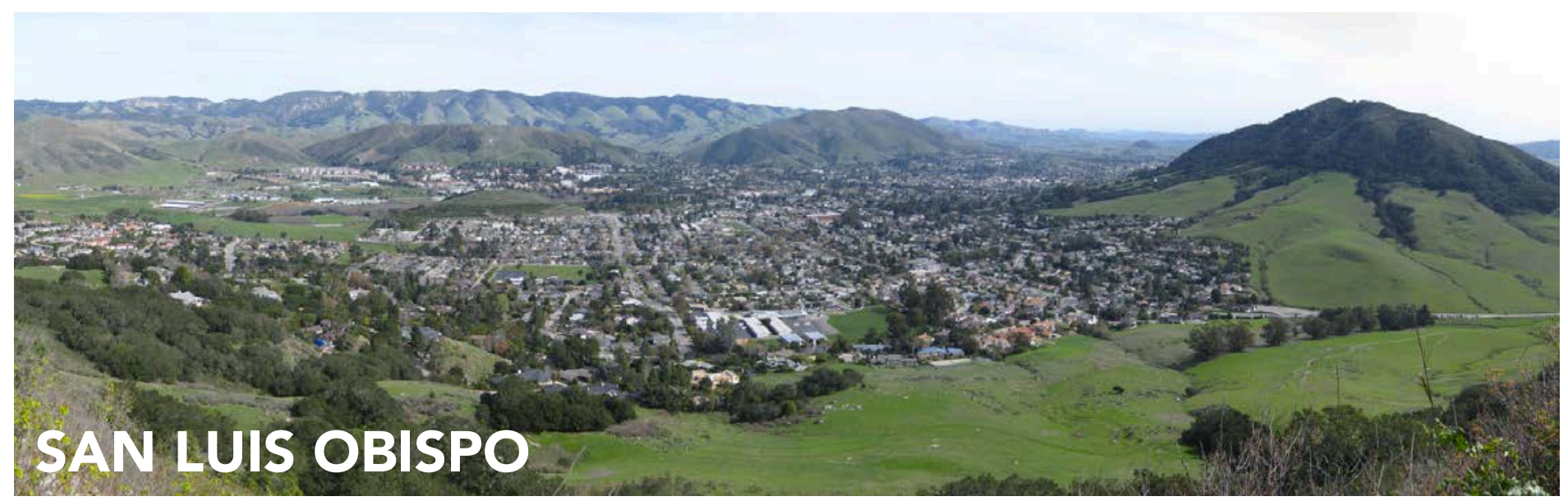

San Luis Obispo, a city of 45,119 residents (2010), defines the southern most boundary of the Byway corridor. The City was first incorporated in 1856 as a General Law City, and became a Charter City in 1876. While San Luis Obispo grew relatively slowly during most of the 19th century, the construction of the Southern Pacific Railroad in 1894 opened up the area to the rest of California.

One of the City's great attributes is its enormously successful downtown. The downtown is centered around the Mission Plaza. Built adjacent to San Luis Obispo Creek, the mission and downtown take full advantage of the creek's setting. A creek-side walkway runs the length of the downtown drawing residents and visitors from the street scene along Higuera Street to a serene yet bustling environment under the canopies of sycamore and oak trees. The city won the coveted "Great American Main Street Award" in 1999. The award is presented to five communities each year for their outstanding main street revitalization through historic preservation.

San Luis Obispo's downtown offers something for everyone: shopping, indoor and outdoor dining, places for relaxing and reading, a vibrant night-life and its consistently successful Thursday night farmers market. The City also serves as the political and geographic center for the County of San Luis Obispo. The County Government Center and Courthouse are located in the downtown. The city is also home of California Polytechnic State University (Cal Poly) and Cuesta College. 


\section{INTRINSIC QUALITIES}

The North Coast Scenic Byway exhibits extraordinary qualities, or resources, which add to the area's appeal to live and visit. For the purposes of this plan these qualities will be referred to as "intrinsic qualities". The National Scenic Byways Program identifies six categories under which these qualities are organized:

- Scenic

- Historic

- Natural

- Archaeological

- Recreational

- Cultural

These qualities are what distinguish the corridor from others in the state and nation. They are also the basis for the corridor's designation as an All-American Road, the highest scenic designation of any road or highway in the nation through the National Scenic Byways Program. The corridor includes significant examples of four of these categories.

\section{Scenic}

The scenic qualities of the corridor are a primary reason behind the desire of residents and visitors to be in the area. The corridor includes a number of natural features that provide travelers with a mosaic of aesthetic scenes to appreciate at any one time. While traveling from the City of San Luis Obispo north through the corridor, travelers will view the following features that add to the area's visual appeal.

\section{SANTA LUCIA COASTASRANGE}

Stretching from San Luis Obispo County in the south to the Monterey Peninsula in the north, the Santa Lucia Coastal Range parallels the central coast. The range is located within the Santa Lucia district of the Los Padres National Forest. Managed by the National Forest Service, the area boasts a large variety of scenic, recreational and natural treasures.

The forest includes a wide variety of natural communities including coastal sage scrub, mixed oak woodlands, chaparral, mixed chaparral, pine forest, bristlecone fir, redwood forests, savanna and riparian forests and woodlands. These ecosystems support a diverse array of plant and animal species. The forest's management plan identifies the protection of these natural resources as a primarily goal, while also allowing limited public access to recreational opportunities.

The forest offers access to a number of outdoor recreational opportunities. Hiking, biking, camping, rock climbing, use of off-highway vehicles are among the activities that the public is welcomed to take advantage of. These opportunities, however, are limited to specific areas in order to limit impacts to the natural communities ${ }^{2}$. 


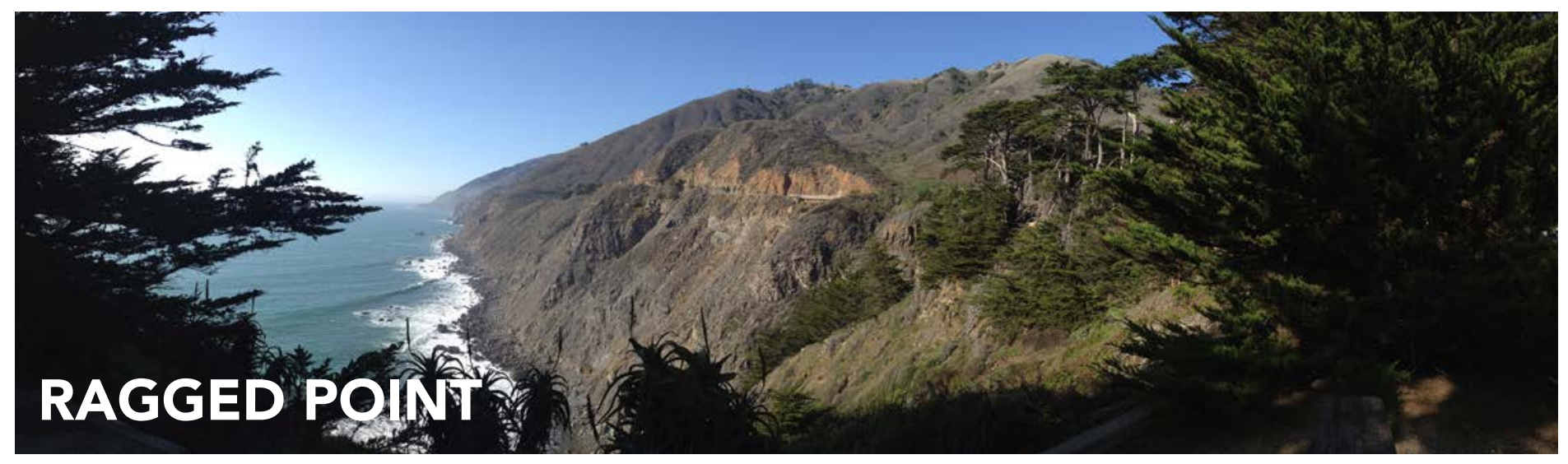

Ragged Point is located 1.5 miles south of the San Luis Obispo/Monterey County Line. The point has a small visitors services area that includes a motel with ocean views, a restaurant and other visitor services. The point provides visitors spectacular scenic vista points with interpretive sites and trail access. The vista points offer unspoiled views of the rugged cliffs to the north, which the highway traverses as it winds into Monterey County on its way to Big Sur and the Monterey Peninsula. To the south, one has views of Breaker Point and Point Sierra Nevada as well as the lighthouse at Piedras Blancas.

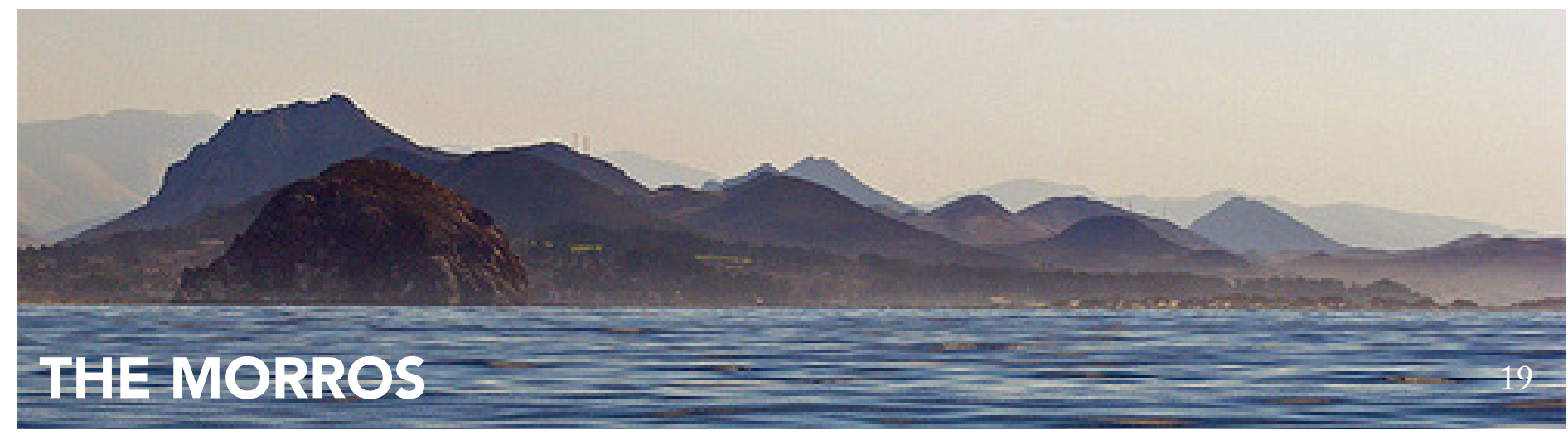

The Morros are a unique set of peaks between the City of San Luis Obispo and the City of Morro Bay. The are the remnants of long-extinct volcanoes, and define the boundary between the Los Osos and Chorro Valley. These prominent landmarks create a unique skyline in San Luis Obispo County, and each peak is distinct in many respects. The Morros are the middle seven peaks, in a chain of nine. The "Seven Sisters" include Cerro San Luis, Bishop Peak, Chumash Peak, Cerro Romualdo, Hollister Peak, Cerro Cabrillo, and Morro Rock. Islay Hill, Black Hill, and Davidson Seamount are also in the chain. Davidson Seamount is off of the coast, 3600' below the surface of the Pacific while Islay Hill is located east of San Luis Obispo and Black Hill sits between Morro Rock and Cabrillo peak. 


\section{ESTERO BAY}

Estero Bay is a crescent shaped bay. It is approximately 19 miles around and extends from Montaña de Oro State Park in the south to Estero Bluffs in the north including the communities of Los Osos, Morro Bay, and Cayucos. In the middle of the bay's arc stands Morro Rock. The familiar landmark is the last in the string of The Morros, as they seem to fall into the sea. The shape of the bay provides travelers a relatively unimpeded view of much of the bay, Morro Rock and the surrounding coastal range. Visible from the highway along most of its length through the corridor, the traveler is provided spectacular views of the Pacific Ocean. 


\section{Historic}

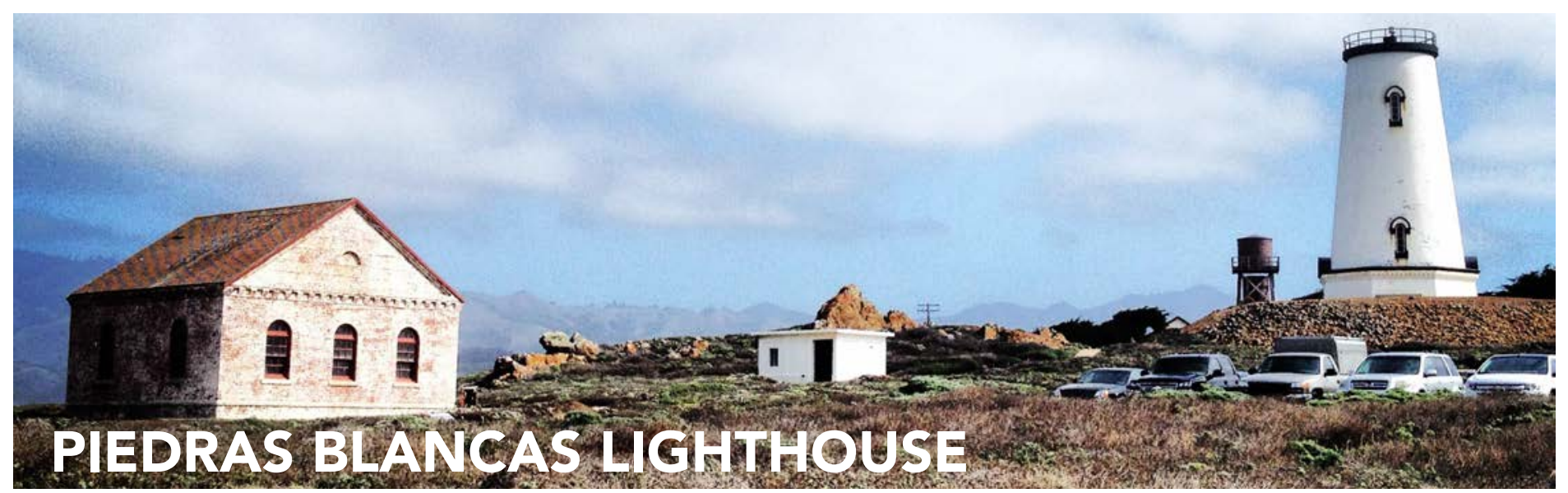

The Piedras Blancas Lighthouse was built in 1874 and first operated in 1875. It was built by the United States Lighthouse Board and operated by the U.S. Lighthouse Service until the Coast Guard assumed command in 1939 and later transferred to the jurisdiction of the Coast Guard. It was one of many built during this period to improve the safety of the ever increasing maritime commerce in the Pacific. Originally constructed 110 feet tall, it was later shortened by the Coast Guard because of concern for the structure in the high winds sometimes associated with the Central Coast. The lens of the light station is currently on display in Cambria, adjacent to the Veterans Memorial Building.

The lighthouse is still in operation today and continues to be is a prominent landmark for travelers on the highway. Its location is the halfway point between the lighthouses at Point Conception in the south and Pigeon Point in the north. Control of the lighthouse and the lands operated by the Coast Guard were transferred to the United States Bureau of Land Management (BLM) in 2000. The BLM continues to operate the lighthouse and provides public access through three weekly tours. Also, the BLM has continued to restore native dune plant communities around the lighthouse and on neighboring State Parks property, as part of a cooperative agreement with State Parks. These lands have been designated by Congress as a federally recognized "Outstanding Natural Area." More information can be found in the 2007 Piedras Blancas Management Plan.

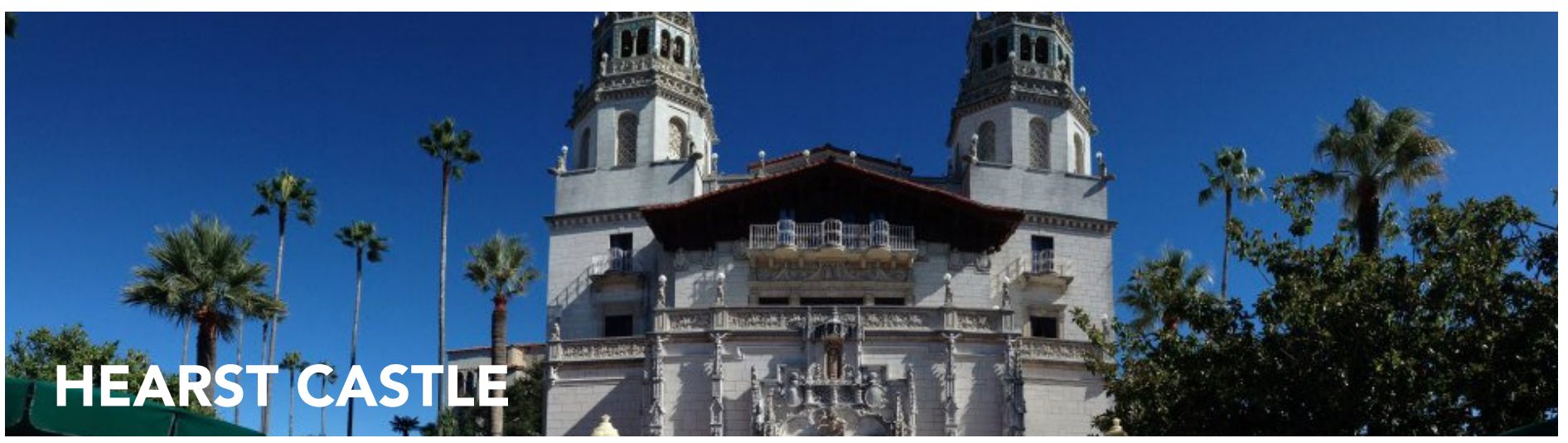

In the Santa Lucia Coastal Range overlooking the Pacific Ocean, Hearst Castle is a magnificent estate of 165 rooms and 127 acres of gardens, terraces, pools and walkways. The castle was once the home of newspaper publisher William Randolph Hearst and the last great estate produced by America's Gilded Age. Relinquished to the California State Park System the castle is a State Historical Monument and largest revenue generator in the state park system. It is the most important tourist destination in San Luis Obispo County with approximately 800,000 visitors per year. 


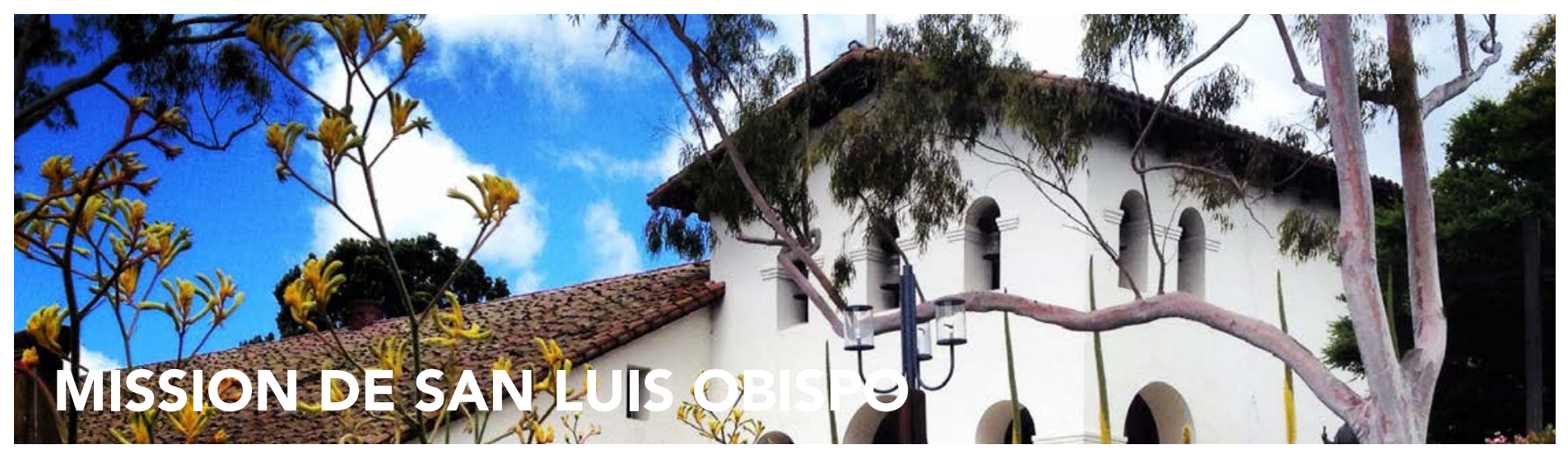

One of California's oldest communities, San Luis Obispo had its beginnings in the founding of the Mission San Luis Obispo de Tolosa in 1772 by Father Junípero Serra. It was the fifth mission in a chain of 21 missions in California. The mission was named after Saint Louis, a 13th Century Bishop of Toulouse, France. (San Luis Obispo is Spanish for "St. Louis, the Bishop".) The site provided a number of qualities necessary for the successful development of a mission: proximity to creeks, fine soils, a native American population, and a mild climate. Father Serra left behind Father Jose Cavaller to coordinate the building of the mission. Within 10 years of the beginning of construction, the mission was a bustling operation herding sheep, cattle, horses and pigs, and growing wheat, corn, and beans.

Today Mission de San Luis Obispo serves as the cultural and literal center of the City of San Luis Obispo's thriving downtown. Visitors to the downtown enjoy the Mission Plaza that adjoins the downtown and its creekside boardwalk. The mission continues to have an active church with regular services and weddings.

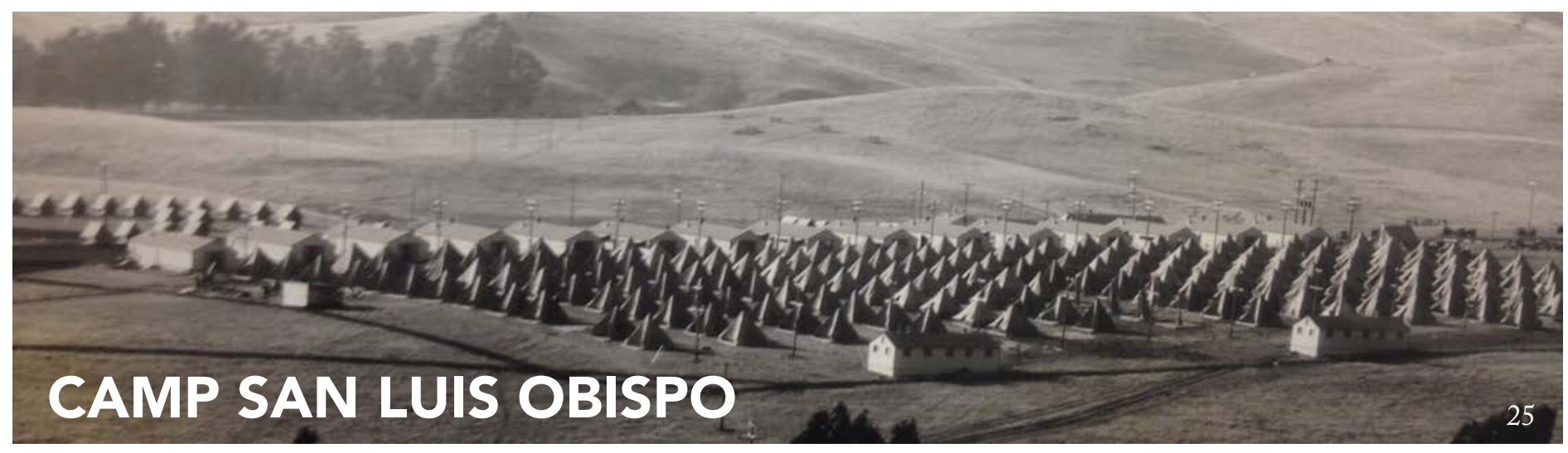

Camp San Luis Obispo is the original home of the California Army National Guard. The camp includes 15,433 acres along both sides of the Byway corridor. It served as an Infantry Division Camp and Cantonment Area for the United States Army during World War II. During World War II, the camp had quarters for over 20,000 enlisted personnel. During the Korean war the camp was used by the US Army, for signal corps training. Today the Camp is used for National Guard training and National Guard Youth program for at risk teenagers. It also is the location of the Conservation Corps State Museum. This museum exhibits the works of the Civilian Conservation Corps in California. One building is a replica of a 1930s Conservation Corps in California barracks, including tools, uniforms and other artifacts. The museum is open by appointment. 


\section{Natural}

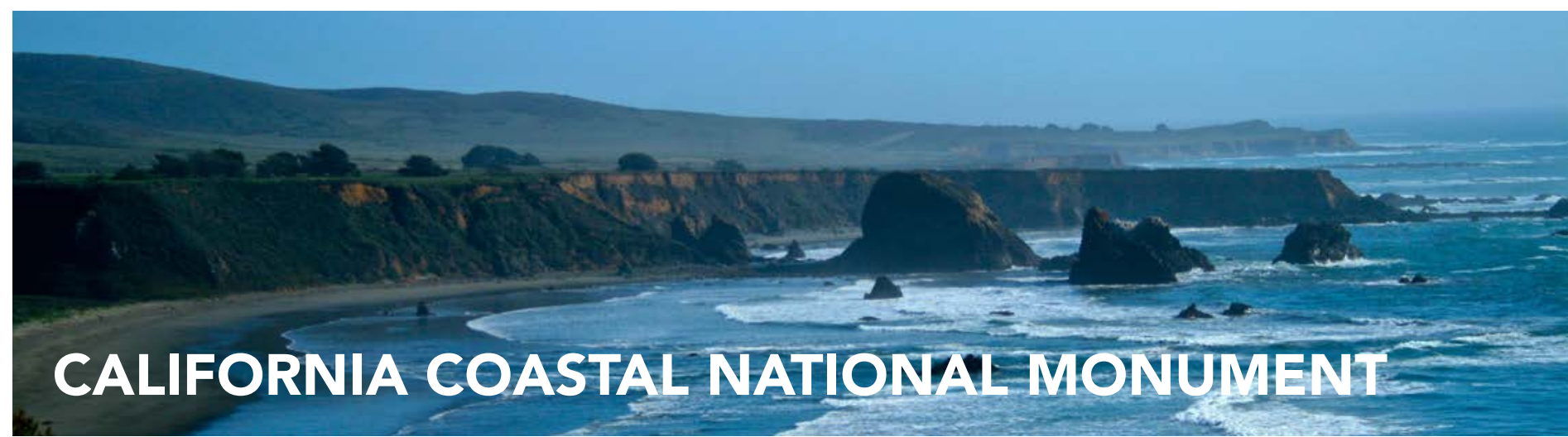

Designated by presidential proclamation on January 11, 2000, the California Coastal National Monument runs the entire length of the California coast (1,100 miles) between Oregon and Mexico, extends 12 nautical miles from the shoreline, and encompasses thousands of BLM administered islands, rocks, exposed reefs, and pinnacles above mean high tide.

Cooperatively managed with other federal, state, local government, universities, and private interests, the primary purpose of the Monument is to protect important biological and geological values. The islands, rocks, reefs, and pinnacles provide forage and breeding grounds for significant populations of birds and sea mammals ${ }^{12}$.

The most pristine landscapes and views of the byway are located in the northern areas of the corridor. Much of this area is the Hearst Conservation Easement and the northern portion of Hearst San Simeon State Park. These views are now permanently protected and the subject of a scenic viewshed easement. The views are some of the most photographed of the area which include the rocky coastline, hills surrounding Hearst Castle, and the Elephant Seal Haulout.

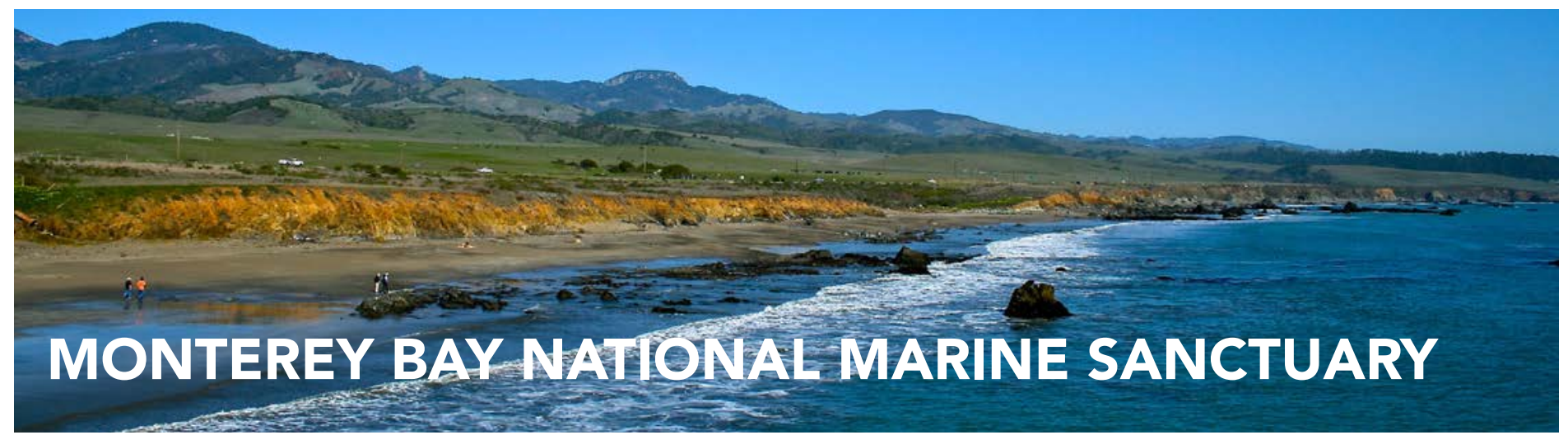

The Monterey National Bay Marine Sanctuary stretches from San Francisco Bay to the community of Cambria; the sanctuary is one of the world's most productive bodies of water. The canyons off the coast of Monterey Bay are twice as deep as the Grand Canyon. This geography is one of the reasons for the area's productivity. Rivers of cool, productive water flow from the ocean bottom contributing to the most varied algal community in North America.

The area supports a large, diverse population of marine mammals, including the California gray whale, finback whale, humpback whale, sperm whale, and California sea otter. The vast productivity of the waters has resulted in an incredible diversity of plants and animals including 26 species of marine mammals, 94 species of seabirds, 345 species of fish, 4 species of turtles, 31 types of invertebrates, and 450 species of large marine algae ${ }^{9}$. 


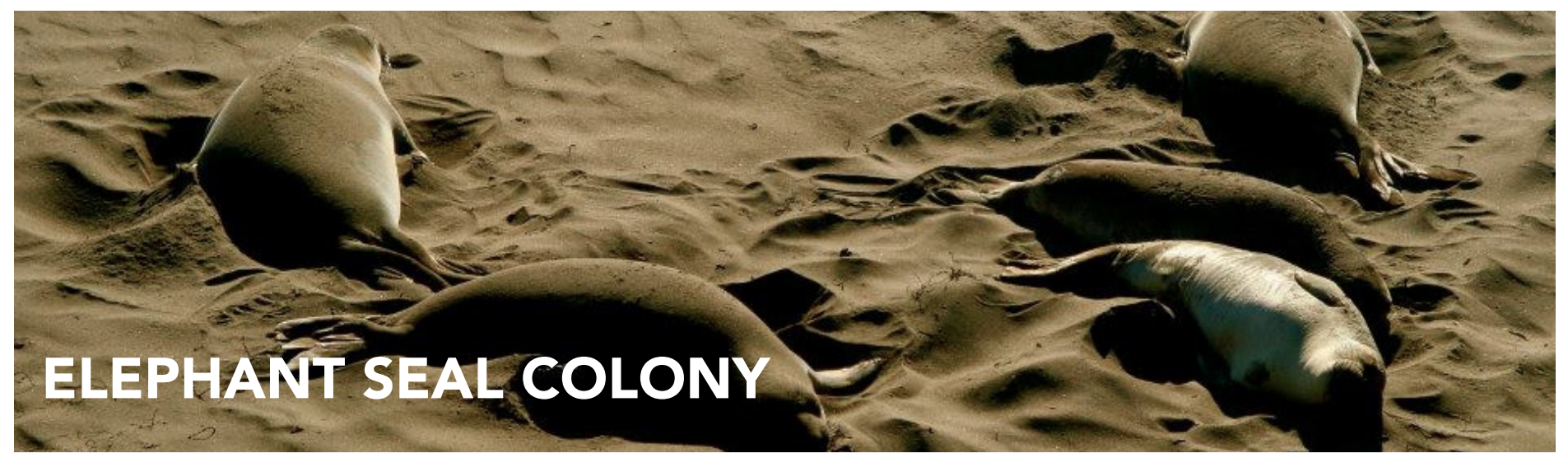

The elephant seal is the largest of all pinnipeds. Adult bulls can exceed two tons in weight and ten feet in length. Like many marine mammals, they were hunted to near extinction in the 19th century.

Until recently, the huge seals lived in isolated areas far away from humans. Then, in 1990, they started colonizing the beaches and coves just south of Point Piedras Blancas. Their chosen location is just off of Highway 1, a few miles north of Hearst Castle. Visitors have the opportunity to view the seals from a boardwalk on the west of Highway 1. The site has a number of interpretive signs for visitor information ${ }^{11}$.

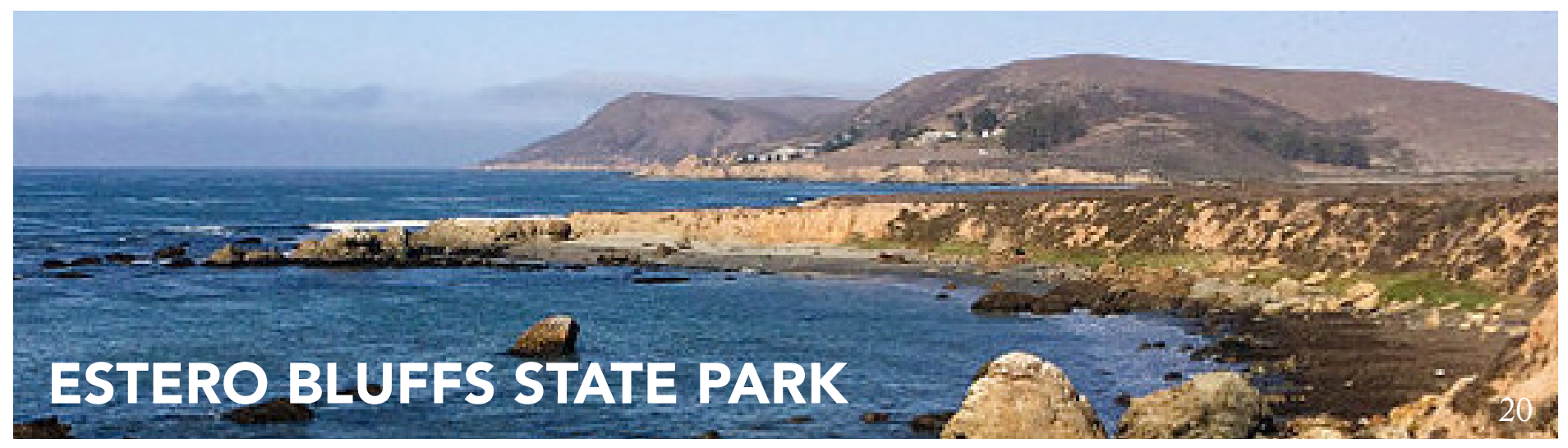

In 2010, SLOCOG assisted in the purchase of the 355 acre property located on the northern part of Estero Bay. Estero Bluffs State Park is used as a greenbelt with scenic viewshed protection, passive recreation, and interpretive efforts. Its location and size ensures that travelers of Highway 1 will have an unobstructed view of Estero Bay, Morro Rock, and the Santa Lucia Range.

Improvements by Caltrans to the pull-offs along Highway 1 have made Estero Bluffs State Park easier and safer to access. Other improvements have been made and include interpretive panels, vista points, and coastal access. Terms of the land acquisition limit development on the property. Structures that are necessary for passive recreational activities are allowed, so long as they are sensitively sited. Such structures include interpretive panels, parking areas, and restrooms.

Estero Bluffs State Park is bordered by the San Geronimo Ranch conservation easement consisting of approximately 900 acres. The San Geronimo Ranch possesses natural, scenic, open space, and agricultural values which are protected as a result of the easements limits on new development. This conservation easement was also acquired with the assistance of SLOCOG. 


\section{MORRO BAY ESTUARY}

The Morro Bay Estuary was included in the National Estuary Program (NEP) in July 1995. It contains the most significant wetland system on California's south central coast. It serves a critical environmental function of the Pacific coast and serves international interests by supporting many species of migratory birds protected by international treaties and provides a protected harbor of off-shore marine fisheries.

The NEP was initiated to address certain provisions of the 1987 amendments to the Clean Water Act. The program identifies, restores and protects those estuaries that are of national significance. The NEP identifies the quality of the estuary's waters, the estuary system, and the watersheds that affect them.

The Morro Bay Estuary Program is guided by the 2012 Comprehensive Conservation and Management Plan (CCMP), which prioritizes health issues of the estuary and watershed and presents actions to effectively address those issues ${ }^{7}$.

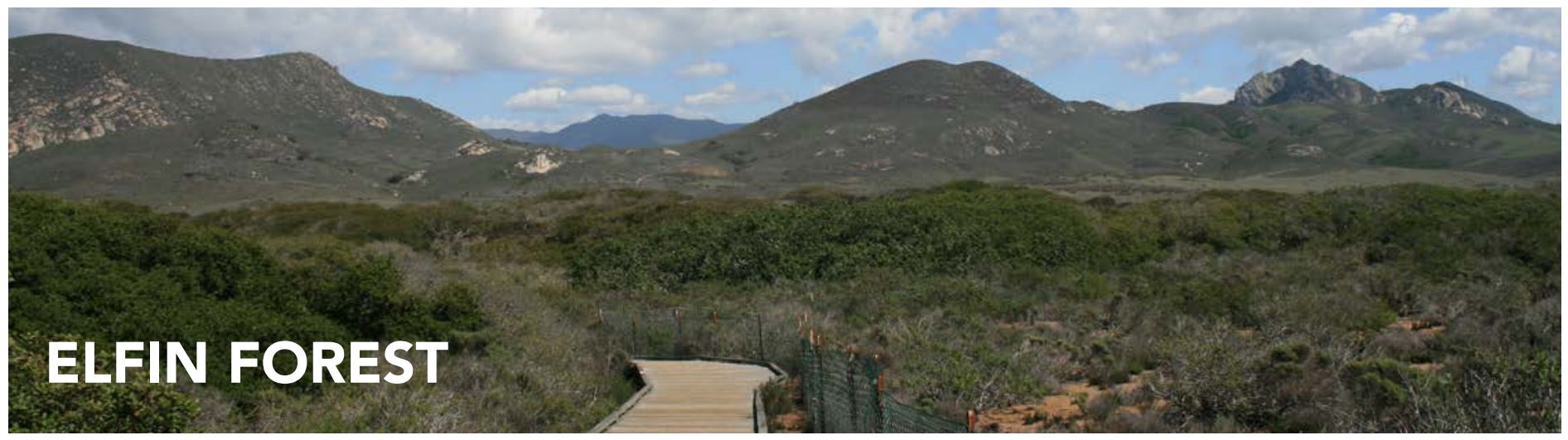

Located on the southeastern shore of Morro Bay, the 90-acre Elfin Forest represents a complex and rich assortment of natural communities. These include coastal brackish marsh, riparian woodland fringe, pygmy oak woodland, grassland, coastal dune scrub, and oak manzanita association. The area has been documented to support 150 species of plants, 25 species of mammals, over 110 species of birds, and 11 species of reptiles and amphibians.

The unusual multi-trunked pygmy oak (Quercus agrifolia) is found in the northern portions of the forest. The tree's relatively small size distinguishes it from other types of oaks. The area is habitat to the Morro manzanita (Arctostaphylos morroensis), a federally listed threatened species. Sulcaria isidiifera, the Federal Register's only listed endangered lichen species, is also endemic to the area ${ }^{8}$. 


\section{Recreational}

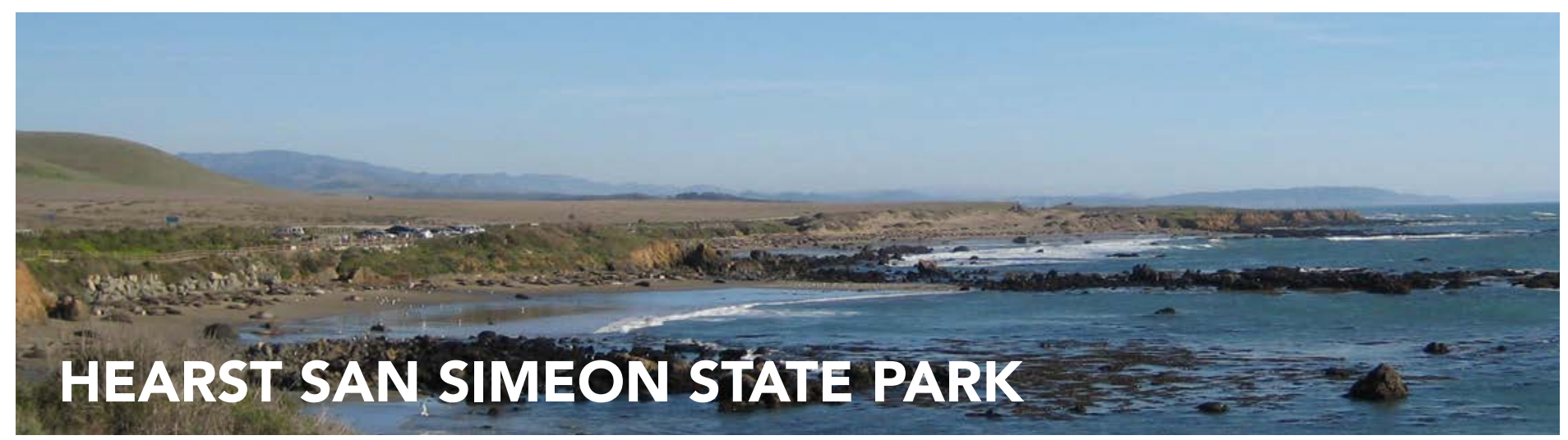

Hearst San Simeon State Park is one of the oldest units of the California State Park System. The coastal bluffs and promontories of the scenic park offer unobstructed views of the ocean and rocky shore. The park includes the Santa Rosa Creek Natural Preserve, the San Simeon Natural Preserve and the Pa-nu Cultural Preserve, which were established in 1990.

A 3.3-mile trail runs through parts of the San Simeon Natural Preserve and the Washburn Campground. The trail includes scenic overlooks, rest-stop benches and interpretive panels with information on wildlife and habitat. A portion of the trail along the seasonal wetland is wheelchair accessible.

- Santa Rosa Creek Natural Preserve is an area, which includes valuable riparian forests and coastal wetlands, that provide habitat for endangered Tidewater Goby, steelhead salmon, and California Red Legged Frogs.

- San Simeon Natural Preserve consists of vast wetlands, riparian areas, and several undisturbed native plant communities that provide habitat for the species listed above and Western Snowy Plover. The Preserve is also the wintering site for monarch butterfly populations.

- The 13.7 acre Pa-nu Cultural Preserve contains the most significant archaeological site within Hearst San Simeon State Park. The site has been dated to 5,850 years before the present, and it contains significant evidence documenting prehistoric technology, subsistence practices and social organization over the course of several centuries.

Hearst San Simeon State Park includes properties extending from the north portion of Cambria all the way to Ragged Point. Hearst San Simeon State Park includes 13 miles of coastline with an additional 5 miles of public access easement on privately owned property. Future improvements may include: alignment of the California Coastal Trail, visitor serving improvements at the Elephant Seal Viewing Area, interpretive panels, access points in the fence line, and facilitated access to the adjacent BLM owned Piedras Blancas Lighthouse. California State Parks acquired the former 20 acre Piedras Blancas Motel property and use there may include limited overnight camping and visitor uses of the structures. A draft of the interim operational guidelines based upon public meetings for these properties is attached in the Appendix. 


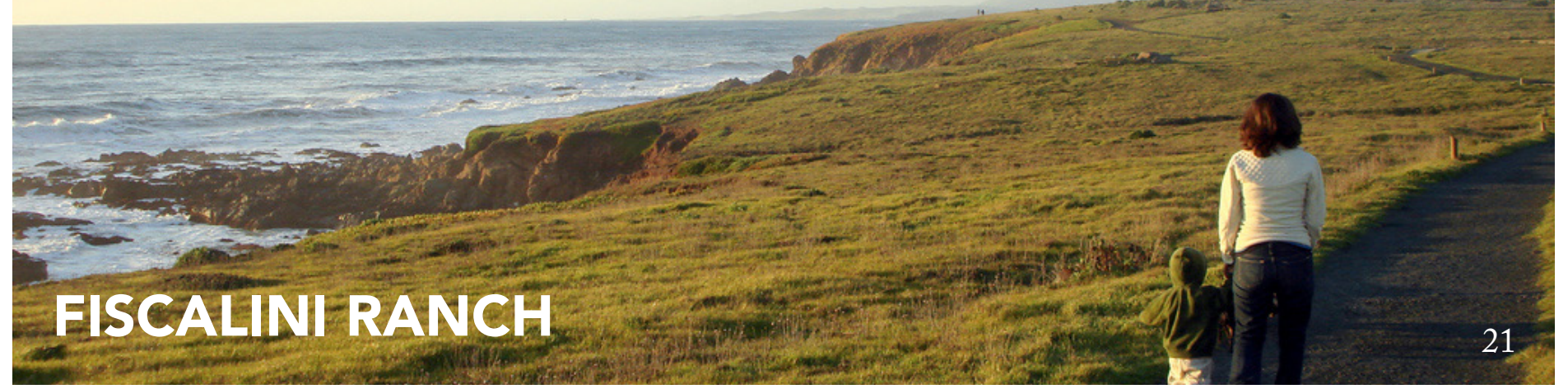

The Fiscalini Ranch is a 407-acre property located in the community of Cambria that was purchased for conservation by a partnership with SLOCOG in 2000. The ranch, formerly known as East-West Ranch, lies in the middle of the town and serves as valuable open space for residents and visitors alike. The ranch brings the community a variety of benefits. Recreational opportunities now include multi-use trails for bicycles, pedestrians, and other users to access the coastline and the ranch's riparian and oak woodland settings.

The most outstanding natural feature of the Fiscalini Ranch is the dramatic ocean bluff that runs approximately one mile along the Pacific Coast Shoreline. The parcel extends almost due east from that bluff and rises to a high point on the property, 400 feet above sea level, before returning to sea level at Santa Rosa Creek. Over half the ranch is grassland, and each spring the Fiscalini Ranch boasts beautiful wildflower displays from scenic Highway One. Native Monterey pines and oak forestlands covers 70 acres of the property. There are two natural springs on the west portion of the ranch and a small wetland on the southeast corner, just above the ocean ${ }^{13}$.

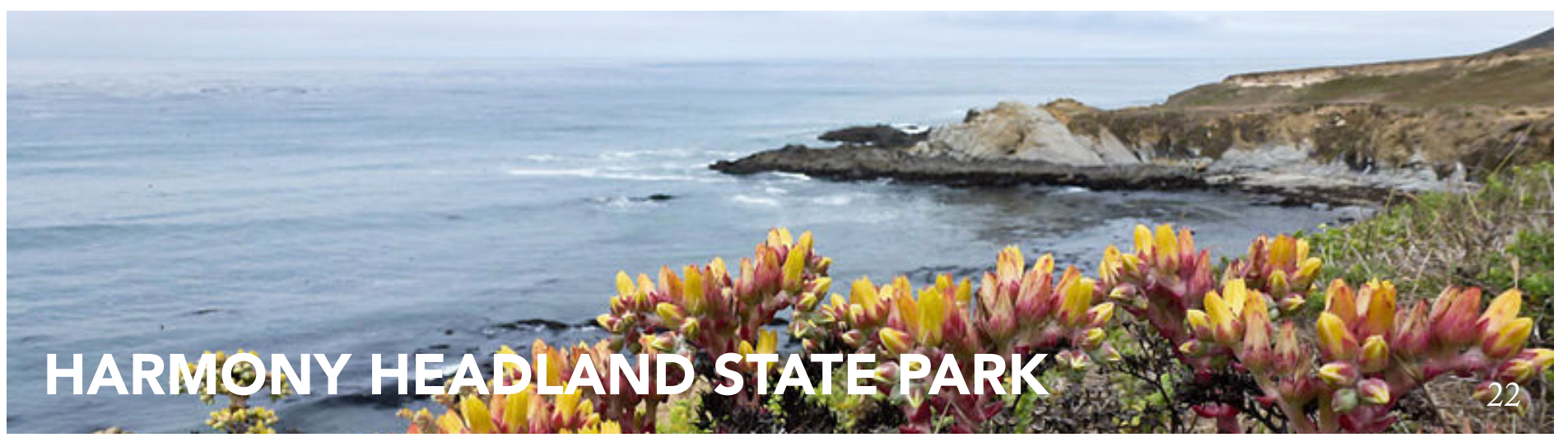

Harmony Headlands State Park is located 2.6 miles south of Harmony adjacent to the byway. Harmony Headlands State Park features a two-mile long Headlands Trail that departs from the parking lot and provides breathtaking ocean views west. Nature lovers, hikers, photographers, artists and bird watchers will all find this walk a rewarding and memorable experience. 


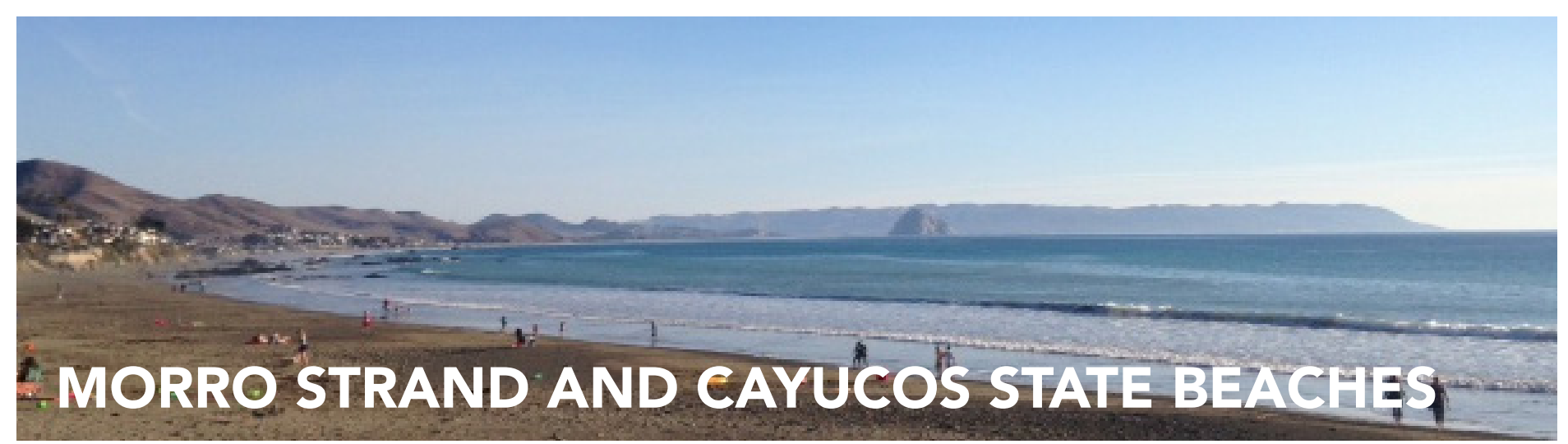

Morro Strand State Beach is a coastal frontage park featuring outstanding picnic sites and a campground including full RV hookups. A three-mile stretch of beach connects the southern and northern entrances to the beach. Fishing, windsurfing, jogging, and kite flying are popular. Cayucos State Beach, operated by the County of San Luis Obispo, is approximately 2 miles to the north and is known for many of the same activities.

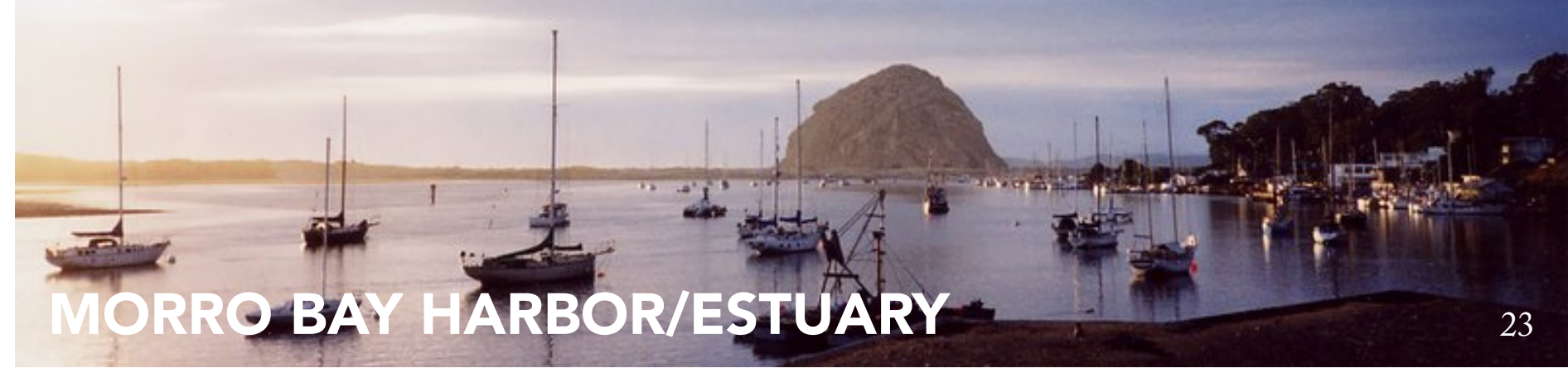

The Morro Bay Harbor and Morro Bay Estuary are not only visually and naturally critical, but also give people opportunities for outdoor recreation. People come from long distances to take advantage of the incredible bird watching available in and around the estuary. With boat and kayak rentals and launches in Morro Bay, visitors can explore everything from the Embarcadero of Morro Bay, to the natural areas of a nationally recognized estuary. Guided tours of the harbor are also available on ferries and glass-bottom boats. Surrounding the bay, trails and bike lanes make exploring the beautiful area from land safe and enjoyable.

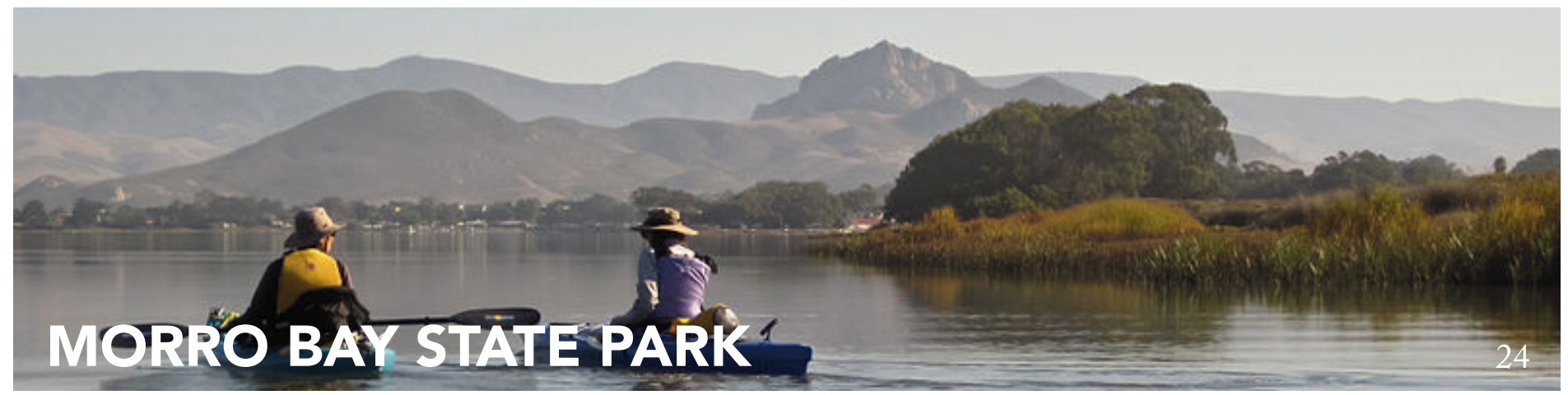

Morro Bay State Park is located just south of the City of Morro Bay. The park is largely sited in a coastal pine forest and eucalyptus forest. The park has opportunities for sailing, fishing, hiking, and bird watching and camping. The Park's museum has exhibits that cover Native American life, geology, and oceanography. The park includes a county operated golf course that is directly adjacent to the bay and estuary. The park also offers full service campgrounds with trail and bicycle access to Morro Bay and surrounding areas. 


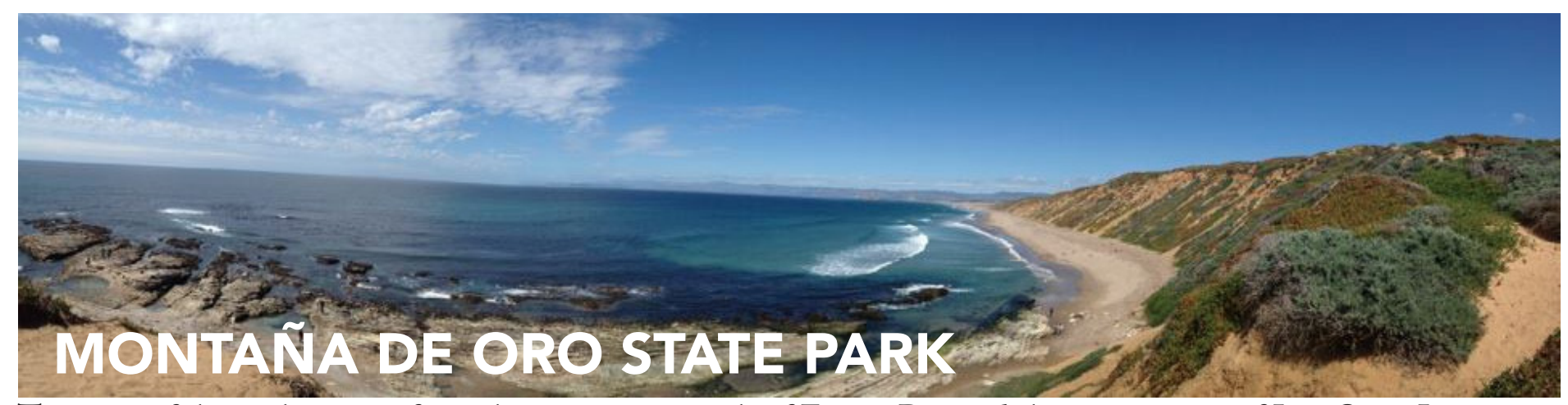

This unit of the park system faces the ocean just south of Estero Bay and the community of Los Osos. Its wave swept, seven-mile long shoreline is made up of sandy beaches along the sand spit to the north, and rugged cliffs and headlands to the south. The central and southern part of the park features a number of small coves with sandy beaches, the most prominent and accessible of which is Spooner's Cove. Inland from the shoreline is an ancient wave-cut terrace that was long ago uplifted from the cutting edge of the surf and now appears as a grass covered coastal plain. The plain sweeps back from the ocean and then curves up sharply upward to 1,500 foot high hills including Valencia Peak from which one can overlook nearly a 100 miles of the coastline from Point Sal in the south to Piedras Blancas in the north.

Coast live oak and Bishop pine occur in the chaparral covered hills, and there are willows, big-leaf maple, box elder, myrtle and black cottonwood trees in the stream-cut canyons. Trails have been developed throughout this uplifted area and hikers are welcome to explore all trails of the park. Motor vehicles must remain on the paved roads.

The park includes more than 8,000 acres, is largely undeveloped, and features a wide range of wildlife including rabbits, squirrels, skunks, raccoons, badgers, deer, fox, bobcats, coyote, and even an occasional mountain lion. There are also many kinds of birds, and in the spring and early summer a brilliant display of wildflowers. It was the predominantly yellow color of these flowers that inspired the naming of the this area - Montaña de Oro or Mountain of Gold ${ }^{14}$.

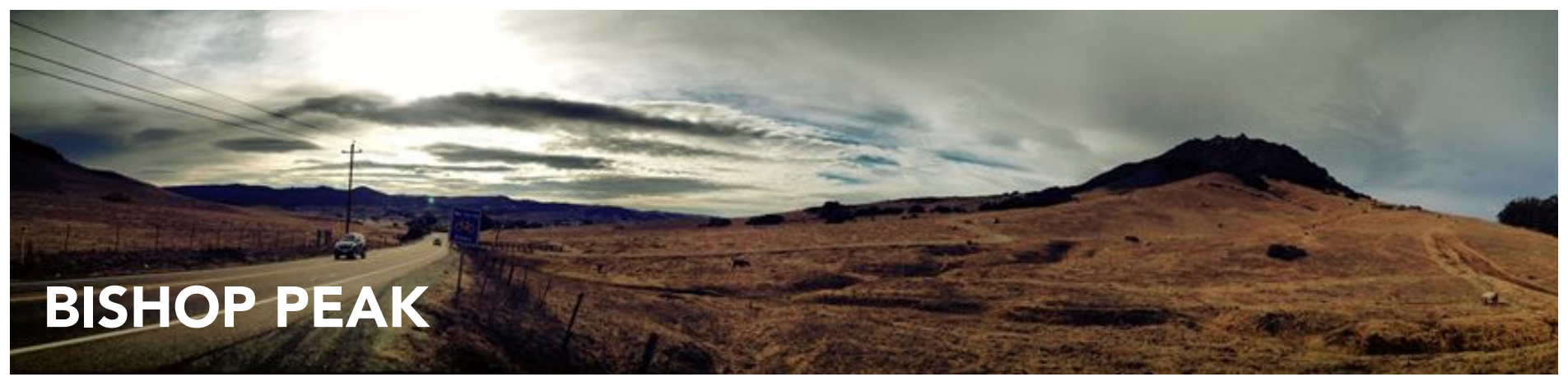

One of seven peaks that adorn the Chorro Valley, Bishop Peak, is also one of the most utilized natural features for recreation in the county. Hikers, rock climbers, bird watchers, and naturalists have long taken advantage of the peak's many features. Hiking the peak became more accessible in 1997 when a hiking trail was established. The introduction of the trail made the area accessible to a far wider group of people. Until then only those willing to take steep routes covered in thick brush and poison oak (Rhus toxicodendron) could take advantage of the area.

The peak offers unobstructed views of all of the Morros, Los Osos and Chorro Valleys, San Luis Obispo, and on clear days, the Pacific Ocean. The 360-degree view from the top of the mountain is one of the best in the region. For naturalists, the area offers a unique habitat for many animal and plant species, including Peregrine Falcon and Red-Tailed Hawks, deer, bobcat, coyote, and many small mammals. Plant communities on the mountain include oak forests and chaparral, and grasslands. The Bishop Peak Natural Reserve also offers ranger-led hikes for those visitors interested in learning more about the area. 


\section{CHAPTER 2 BYWAY VISION AND IMPROVEMENTS}

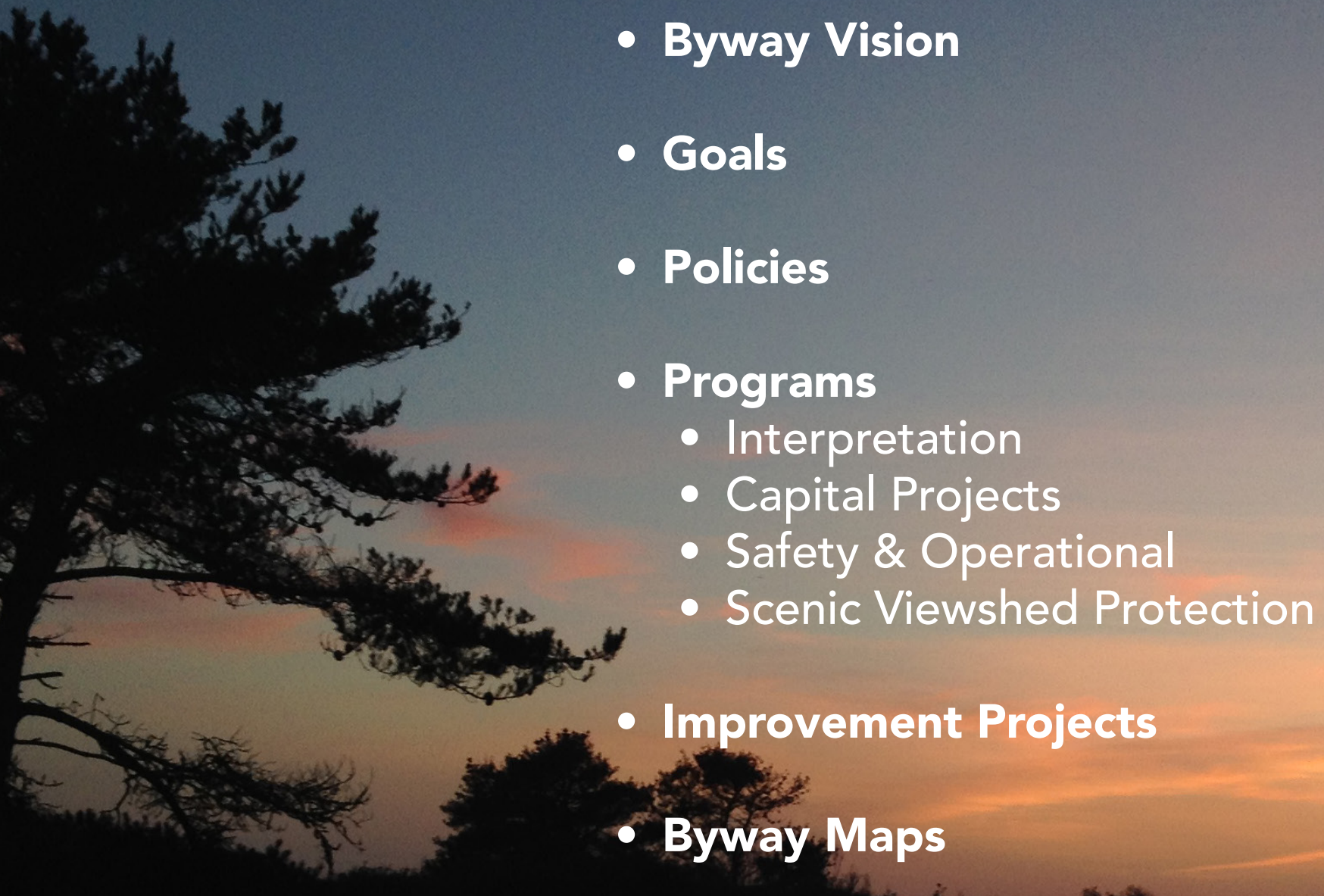




\section{Byway Vision}

The San Luis Obispo Council of Governments is recognized by the Federal Highway Administration as the SLO North Coast Scenic Byway Organization. This brings the responsibility of developing a plan to maintain and enhance the Byway and ensure that requirements of the Scenic Byway Program are addressed. SLOCOG's vision for the corridor is consistent with other major stakeholders in the area.

\section{Byway Vision Statement:}

"Protect the corridor's intrinsic qualities and natural resources, while enhancing access, transportation facilities, and educating the traveling public."

\section{Byway Goals}

A. Protection of intrinsic qualities and resources

B. Improved off-highway non-motorized access

C. Development of the California Coastal Trail

D. Maintain and enhance scenic viewsheds

E. Improved access to public lands, balanced with protection of natural resources

F. Enhanced aesthetics of highway facilities

G. Commitment to public outreach and involvement

\section{Byway Policies}

\section{Highway Facilities}

Conform to the highest possible aesthetic design standard approved for use on the state highway system where appropriate for the site and context.

- All bridges and guardrails aesthetically designed where appropriate for the site and context.

- All fencing designed using highest standards and sited in a way not to obstruct scenic viewsheds, to the greatest extent feasible consistent with safety requirements.

Caltrans and SLOCOG staff develop a method for efficient collaboration on draft project initiation and environmental documents to address scenic Byway issues and concerns.

- SLOCOG ensure that projects required to be in its federally required Transportation Improvement Plan (TIP) are reviewed by the Byway Advisory Committee prior to inclusion in the TIP.

- Encourage the use of the existing alignment/ roadbed as part of the California Coastal Trail, with ADA (Americans with Disabilities Act) compliance

- Maintenance and rehabilitation of highways and shoulders should consider the needs and safety of all travel modes.

\section{Off-highway Enhancements \& Non-motorized Facilities}

- SLOCOG support local efforts to underground utilities, remove billboards, and improve adjacent highway facilities with hardscape (i.e. textured crosswalks) and landscaping.

- SLOCOG supports the development of a walking and bicycling trail on or near the highway to serve as the non-motorized Scenic Byway. Between the Monterey County line and Morro Bay this is also the California Coastal Trail. Between Morro Bay and San Luis Obispo it is the Chorro Valley Trail.

\section{Interpretive Elements}

- In order to ensure that interpretive topics are implemented over time, implementation plans for interpretive elements are encouraged to be brought to the Byway Advisory Committee for review, comment, and consensus building.

- Interpretive elements in the Byway corridor incorporate the SLO North Coast Scenic Byway and America's Byway logo for continuity of traveler experience.

\section{Byway Branding}

- Members of the Byway Advisory Committee take efforts to advance the SLO North Coast Scenic Byway Branding Theme through the use of the approved Byway logo on facilities and interpretive media.

- The Byway Advisory Committee develop guidelines for the Byway logo and its placement. 


\section{PROGRAMS}

\section{Byway Programs (Improvements)}

There are four primary improvement programs:

1. Interpretation

2. Access Improvement Projects

- Bicycle and Pedestrian Improvements

- Scenic Vista Points

3. Safety and Operations

4. Scenic Viewshed Protection

Specific projects included in the Byway program were drawn from a number of different local, regional, state, and federal plans including:

- Parks and Recreation Element (2006)

- The California Coastal Trail Guide for San Luis Obispo County (2007)

- SLOCOG's 2010 Regional Transportation Plan (RTP)

- Morro Bay General Plan (1988)

- North Main Street Specific Plan (1989)

- Morro Bay Bicycle \& Pedestrian Master Plan (2012)

- County of San Luis Obispo's North Coast Area Plan (Revised 2008)

- Estero Bay Area Plans (Revised 2009)

- Caltrans' State Highway Operation and Protection Program Plan 2013 (SHOPP)

- California Department of Parks and Recreation Morro Bay State Park

- San Simeon State Park North Coast Acquisition Interim Guidelines

- Morro Bay National Estuary Program Comprehensive Conservation and Management Plan (2012)

- NOAA Monterey Bay National Marine Sanctuary Management Plan 2008 (MBNMS)

- California Coastal Conservancy Coastal Trail Plan, "Completing the California Coastal Trail"

- Northern San Luis Obispo Coastal Trail Plan (2012)
The improvements planned for the corridor incorporate those projects that are identified in the 2010 Regional Transportation Plan (RTP), as well as others in the corridor planned by stakeholder agencies. There is not a strict prioritization of the projects identified in the plan, and the plan is primarily focused on short and midterm projects (spanning the next ten years) due to the fact that activities in the corridor have been relatively fast paced in recent years.

Short and Mid Term - Projects that currently have funding programmed for their development and/or construction OR will by 2024 .

Long Term - Projects where no reasonably expected revenue sources exist for development and/or construction by 2024 .

Unconstrained - Projects where reasonably expected revenue sources exist for development and/or construction between 2024 and 2034.

Due to the extensive goals of in the BCP, some improvements identified in the plan will not be able to be completed in the plan's time frame (20 Years). While there are projects considered very high priority in the Access Improvement and Safety/Operations Programs, there is a desire to balance improvements so that other priorities move forward that will compliment improvements made. For example, as important projects such as the Morro Bay harbor walk extension and Morro Bay - Cayucos Connector are implemented, there should also be an emphasis on implementing interpretive elements as a part of those facilities. Since the corridor is designated "All-American Road", there is a desire to continue implementing a Byway branding program that brings continuity to travelers' experiences. 


\section{INTERPRETATION}

One of the primary goals of the $\mathrm{BCP}$ is to improve the interpretive elements along the Byway. Interpretive elements are those media that provide travelers of the highway with educational information and improve their understanding of the corridor's qualities. Examples of completed elements in the corridor include: educational signage, interpretive signs, way finding signage, kiosks, exhibits, tours, and brochures. These elements are incorporated into areas that Byway travelers are drawn to, and which provide access to the intrinsic qualities being described.

Some of the images and features most recognized in San Luis Obispo County include the Morros, Morro Bay Estuary, Hearst Castle, and the rocky coastline of the north coast serving as the southern gateway to the Big Sur Coast All-American Road. The locally stated marketing objective of the San Luis Obispo County Visitor's Conference Bureau (VCB) is to institute a "branding" campaign that provides a very pleasant image depicting San Luis Obispo County as a natural escape. Visitors bond to this region as "California's Natural Escape," providing renewal, peace of mind, and a getaway from the urban areas of San Joaquin Valley, Los Angeles Basin and the San Francisco Bay Area, with its year-round weather for experiencing the natural treasures of the county.

Highway 1, San Luis Obispo North Coast Scenic Byway, is one of the focal points of tourism activity in this county, with approximately 800,000 visitors traveling to Hearst Castle each year. On a "universal access" level, one of the greatest opportunities to inform and educate the visiting public of these natural and historic treasures will be at the Hearst Castle visitor's center. Other opportunities to provide integrated ADA access, that is the development of facilities with careful consideration of individuals with different physical, mental, and social needs, is a stated objective for the interpretation of natural, historic, and cultural information for the Byway.

\section{Interpretive Goals \& Objectives}

- To provide information to visitors about the natural, historic and cultural resources on the San Luis Obispo North Coast Byway in a manner that they might use this information to educate and promote interest in the corridor while supporting a traveler experience complimentary with the overall Scenic Byway goals along Highway 1.

- To increase public awareness of the management activities of conservation groups and local, state, and federal public agencies, and therefore encourage on-going preservation efforts.

- To more fully distribute and publicize, utilizing a variety of media (brochures, guides, social media), the Byway's intrinsic qualities.

- To utilize media technologies which require less visual clutter and built elements in the scenic viewshed while maximizing interpretive opportunities.

- To develop integrated ADA facilities to accommodate all people visiting the San Luis Obispo North Coast Scenic Byway.

\section{Types of Interpretive Media}

\section{Visitor Centers}

The Hearst Castle Visitor Center is an excellent public facility managed by the Department of Parks and Recreation. The observation deck on the east end of the castle's visitor center complex offers a wonderful vantage point from which to view Hearst Castle 1,600 foot above the center. In the Center, visitors are able to view, Hearst Castle - Building the Dream, on the Hearst Castle theater 5-story screen.

Coastal Discovery Center at San Simeon Bay, located at W.R. Hearst Memorial State Beach, the new center highlights the connection between the land and sea 
through engaging exhibits and interpretation provided by highly trained volunteers. The Center offers an exciting way for visitors to learn about the natural and cultural treasures of the region, and the role sanctuaries, parks, and the public play in protecting these treasures for future generations. This new environmental interpretive facility provides education to the public about the region's spectacular offshore and land resources. ${ }^{15}$

The Morro Bay Natural History Museum, located in Morro Bay State Park also provides the traveler with the opportunity to gain insights into the natural interpretive qualities of the corridor.

\section{At Site in the Byway}

\section{Signage}

Interpretive signage provides visitors to a site with a story to enhance the experience. The SLO North Coast Scenic Byway Interpretive Signage Plan is provided in whole for reference in Appendix A. Signs are not designed to provide detailed information, but to bring interest, thought and understanding of what visitors are seeing and experiencing. It is recommended that a site have a common and consistent theme and/ or message between the media to reinforce what is trying to be conveyed about the site and the overall corridor. Examples include:

1. SLO North Coast Scenic Byway Interpretive Signage Plan (Appendix A)

2. Caltrans Vista Point Interpretive Signage

3. Friends of the Elephant Seals Interpretive Signs

4. City of Morro Bay Interpretive and Wayfinding Signs

5. SLO City Signage Program

6. State Park Signage Program

\section{Along Route 1}

Signage is an important element in the improvement of the corridor. There is a need to strike a balance between providing information to travelers and avoiding unnecessary clutter. Caltrans has the authority to regulate signage on the state highway system and all highway signage is required to meet their approval.
Standards for scenic highway signing are published in the Caltrans Traffic Manual. They call for the following:

- Posting standard poppy signs (48" x 26"), when appropriate, with the words "scenic route," to identify routes, which have been designated as official state scenic highways. The sign is installed on the right at the beginning of the scenic route. A standard sign indicating "begin" (26" x 12") may be used with this sign.

- Posting standard poppy signs (12"x 18" or 18" x 27") at beginning, end and/or intermittent locations on the state scenic highway. These signs are posted below and on the same post as the route shields. On conventional highways, these signs will be installed at important urban and rural intersections and at three- to five-mile intervals in rural areas. Standard signs indicating "begin" (26" x 12") and/or "end" (18" x 12") may be used in combination with these signs.

- Posting standard five-sided poppy signs (18"x 18 " or 24 "x 24 ") at beginning and/or intermittent locations on the county scenic highway.

\section{Byway Designation/Logo Signs}

SLOCOG believes that an important part of the branding of the Byway corridor as a unique area that has been bestowed special recognition should be communicated to Byway travelers. It is this communication element that will help foster interest and encourage them to seek more information about the Byway corridor and what it has to offer.

The National Scenic Byways Program encourages use of the America's Byway logo as a part of the branding of the Byway's program. To support national recognition and maintain interregional continuity, SLO envisions using the America's Byways logo in addition to the SLO North Coast Scenic Byway logo, which can be seen below. As stated in the Interpretive Signage Plan, “The SLO Coast Byway logo will be attached to road signs carrying the California Scenic Route "poppy and mountain" logo." This logo was approved by the Board in October 2010. 


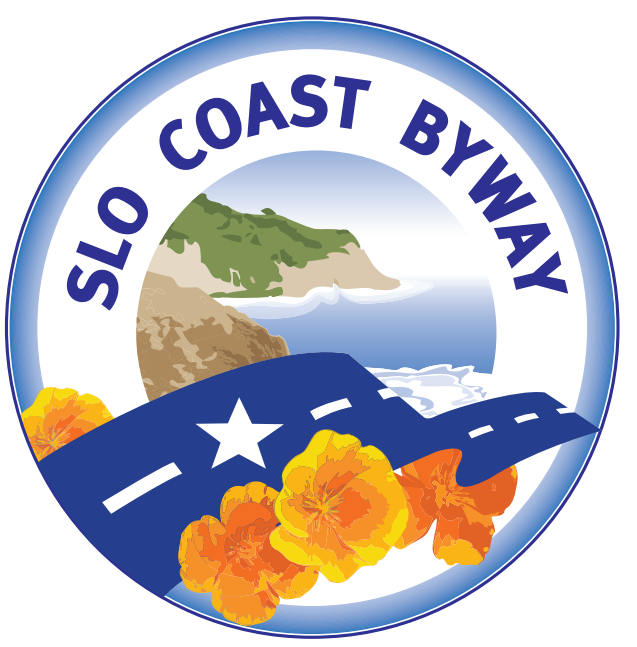

Signage Recommendations:

Initiate a comprehensive signage plan for the corridor to include:

- Design and placement of scenic Byway signage

- Guidelines for each category of sign (i.e. regulatory, visitor serving, etc.)

- Recommendations on existing signs (retain, remove, or relocate)

- Guidelines to minimize "clutter."

\section{Kiosks /Wayside Exhibit Panels}

Kiosks range from covered signs to roofed structures, which provide information. An interpretive kiosk or wayside exhibit panel shall be placed at selected major access points that have outstanding interpretive features. Since various agencies will be responsible for the design, fabrication, and installation of the kiosks or wayside exhibit panels the design will be the responsibility of the agency. However, each kiosk or panel should include the SLO North Coast Scenic Byway Logo. Each jurisdiction is encouraged to also include their logo adjacent to other partner logos. Kiosks offer several advantages.

- Kiosks are larger and trail users who visit parks will identify these structures as places to get information. In addition, these structures provide shade to the viewers.

- Kiosks need to be placed in locations that do not block or impact the view shed, or intrinsic quality.

- Materials used are high-quality, durable material.

- Designs of the interpretive panels are attractive and professional.

The site of the kiosk should meet current
American with Disabilities Act (ADA) standards.

\section{Spotting Scopes}

Spotting Scopes offer visitors a better view of the elements that are being interpreted. These should be provided at sites that include interpretation of intrinsic qualities that would be enhanced with the use of optical magnification.

\section{Tours}

Guided and self-guided tours are offered by different agencies along the scenic byway. Guided tours vary in length and topic by location and may cover natural and/or cultural history. Self-guided tours are available at some trailheads and are usually accompanied by interpretive panels spaced out along a walkway or trail, or by brochures that direct byway explorers to different viewing spots and give interpretive information specific to what can be seen from each vantage point.

\section{Opportunities and Constraints for On-Site Interpretation}

The interpretation of the Byway will occur over long periods of time. Since a number of agencies will be contributing to the interpretation of Byway resources, we encourage the use of the guidelines from the Interpretative Signage Plan and the following:

1. Determine the specific location of the kiosk or wayside panel in order to maximize the intended purpose while not adversely affecting scenic quality or other resources.

2. Provide access to the disabled community, and ensure compliance with the Americans with Disabilities Act, as reasonable.

3. Hire an exhibit designer to develop the interpretive panels that go in the interpretive kiosks or the wayside exhibit panels. These tasks will involve:

- Complete research and work with staff to fine-tune the theme, text, and proposed graphics for each panel.

- Collect the graphic resources (maps, drawings, 
photograph, and artwork).

- Copyright permission will need to be acquired.

- Complete the design approval process by having key partners and selected public members review the draft interpretive panel.

- Fabricate the interpretive panel/s.

- Install the wayside interpretive panels or place the interpretive panels into the installed kiosks.

4. Maintain the kiosks and wayside panels. They must be periodically inspected, damaged sections repaired, vandalism repaired or graffiti removed, and deteriorated panels replaced. ${ }^{16}$

5. Investing in smart technologies such as $\mathrm{QR}$ codes connecting to a website and or a mobile application can reduce visual clutter and resource use. These technologies should be considered when additional interpretation improvements are desired.

\section{Interpretation by Byway Segment}

The following section outlines the Interpretive Zones of the Byway and the recommended topics, themes to be present in interpretive media, for each of these zones.

\section{San Simeon North}

Northern County Line to San Simeon

\section{Topics}

- History of Hearst Castle

- Piedras Blancas Lighthouse

- "Carmel-San Simeon Highway"

- California Coastal Trail

- Monterey Bay National Marine Sanctuary

- Elephant Seal

- Coastal Resources

\section{Existing Programs}

Hearst Castle - (History, Educational Programs/ California Department of Parks and Recreation) Besides the principal objective of preservation and protection of Hearst Castle, the most important aspect is the interpretation of the Castle to the public. The observation deck on the east end of the castle's visitor center complex offers a wonderful vantage point from which to view Hearst Castle 1,600 feet above the center. In the Center, visitors are able to view Hearst Castle - Building the Dream, on the National Geographic large format IMAX theater (five-story screen with seven-channel digital surround sound).

Five tours, led by experienced guides/docents, are offered to witness first-hand the majesty and beauty of this historical treasure. Located in the Visitor Center is The William Randolph Hearst exhibit offering guests an insightful look into the Castle, its architect Julia Morgan, and its owner W.R. Hearst. Family histories, vintage photographs, and historical documents provide a more intimate look at Mr. Hearst's personal life. In the "touch gallery" of the Visitor's Center there is a display of tiles, marble, textiles, and other materials used in the art and architecture of the Castle that allows guests to experience the collection in a tactile way not allowed on the tours.

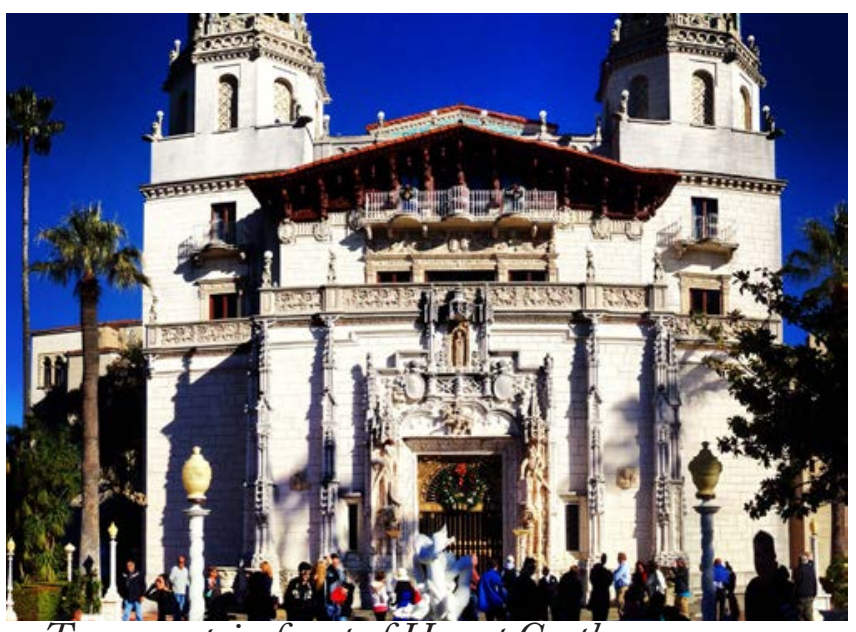

Tour group in front of Hearst Castle.

Marine/Coastal Ecosystem - (California

Department of Parks and Recreation, California Department of Fish and Game, and the Monterey Bay National Marine Sanctuary Program) There are a number of vista points in the Big Sur Gateway that provide visitors with the opportunity to learn about the marine ecosystem. Located along Moonstone Beach Drive in north Cambria, at William Randolph Hearst Memorial State Beach in Old San Simeon, and Ragged Point, the vista points give ideal views of the coastline. Kiosks located in these areas provide information along trails and at coastal access points 
about the California Sea Otter, Elephant Seal colony, and other marine resources

Piedras Blancas Lighthouse - (History, Limited Public Access, Educational Programs/Bureau of Land Management, Cambria Historical Society, and California Department of Parks and Recreation). The Piedras Blancas lighthouse tower and the oil house building were listed on the National Register of Historic Places. A tour runs three times per week, meeting at the Piedras Blancas Motel. As a result of existing native dune plant community restoration projects between State Parks and the BLM, Congress has designated the lands around the lighthouse as a federally recognized "Outstanding Natural Area." Environmental education for schools and citizens in the area, active volunteer groups to help maintain and operate the site, and partnerships with California State Parks, the Friends of the Elephant Seals, Cambria Historical Society and others will provide opportunities to share resources and expertise. The development and opening of this site will provide access to a part of the California coast that has been locked up for 126 years. Guided tours, in coordination with Hearst Castle tours, will structure access and limit operational impacts to Highway 1.

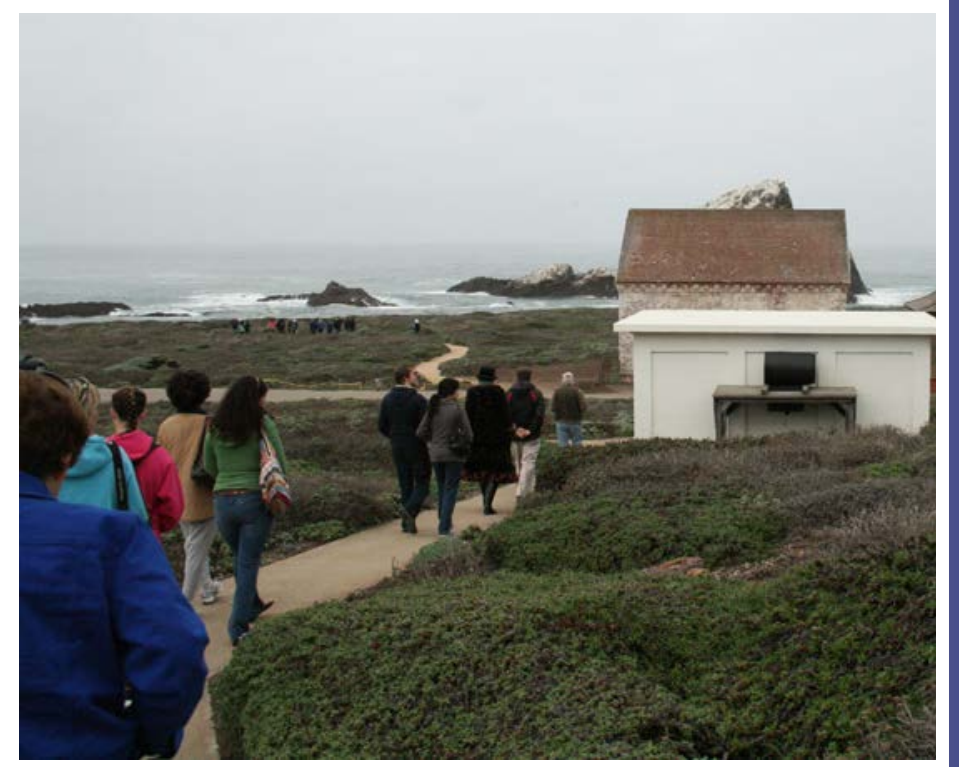

Tour groups walking the Piedras Blancas Lighthouse grounds.

\section{Harmony Coast \\ San Simeon to Villa Creek}

\author{
Topics \\ - Harmony Valley \\ - Dairy farming history \\ - Cambria Air Force Station History \\ - Cambria \\ - Coastal Pine Forest \\ - History of Town \\ - Route 1
}

\section{Existing Programs}

Fiscalini Ranch - The ranch recently unveiled a number of new interpretive panels for visitors to the ranch.

The Cambria Historical Museum (formerly the Bianchini House) - History, Educational Museum/ Cambria Historical Society-Cambria Community Services District was awarded grant funds by SLOCOG, which were used to restore and preserve the Bianchini House as a museum and a community center in the town of Cambria. This pioneer home and its heritage gardens have become a village centerpiece, cherished by visitors and locals for generations. The Cambria Historical Society has produced and updated a permanent exhibit about the historical CarmelSan Simeon Highway (also known as the Roosevelt Highway in honor of President Theodore Roosevelt), which provides visitors the opportunity to appreciate the historical significance of Highway 1.

Coastal Discovery Center - As stated before, the Coastal Discovery Center at San Simeon Bay, located at W.R. Hearst Memorial State Beach, the new center highlights the connection between the land and sea through engaging exhibits and interpretation provided by highly trained volunteers. The Center offers an exciting way for visitors to learn about the natural and cultural treasures of the region, and the role sanctuaries, parks, and the public play in protecting these treasures for future generations. 


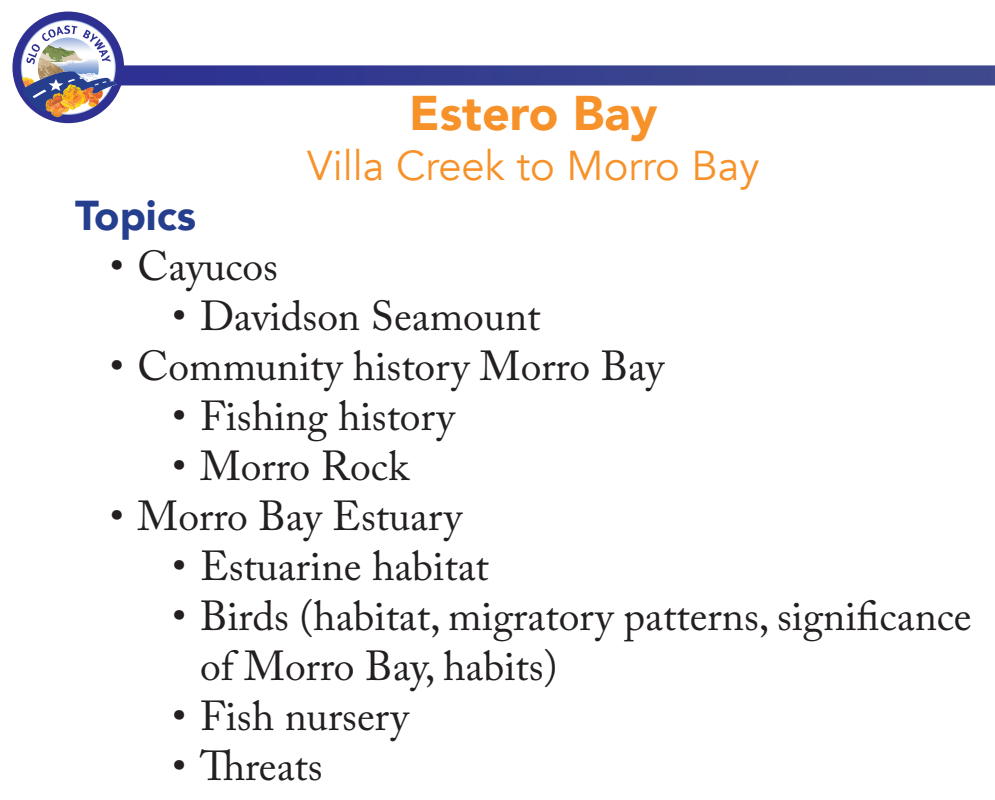

- Route 1

\section{Existing Programs}

Morro Bay Museum of Natural History (Educational, Children's Program, Vista Overlook/ California Department of Parks and Recreation) The Museum includes 26 interactive exhibits, plus seasonal and rotating exhibits. Topics interpreted include: the "forces of nature," estuary, plants, wildlife, Native Americans, human impacts on the area, and more. Renovations were completed in 2010 to make the Museum compliant with the Americans with Disabilities Act (ADA).

The museum also offers educational programs, known as the "estuarine experience." The program includes 4 subject areas: Estuary, Birds, Marine Mammals, and Native Americans, a hike up one of the Morros, a trek to a bird rookery, a scientific exploration of the mudflats, up-close demonstrations in the museum's learning center, and a session of hands-on activities. Discussions at each venue reflect the new state science standards for grades 3 to 7 . All this happens under the direction of trained docents.

\section{The Morros/ Chorro Valley Morro Bay to San Luis Obispo}

Topics

- Morros - Geologic Processes, habitats, meteorology

- Camp San Luis Obispo

- SLO to Morro Bay RR Line

\section{Existing Programs}

Bishop Peak Natural Reserve - The reserve offers ranger-led hikes for those visitors interested in learning more about the area. Available times can be found of the City of San Luis Obispo's Website.

Rancho El Chorro - (Educational and Children's Program/San Luis Obispo County Office of Education) Tucked away in the hills above San Luis Obispo is the Rancho El Chorro Outdoor School, a natural preserve, a school campus, and an extraordinary learning resource. Here, on 250 protected acres, elementary students literally reach out and "touch" the natural world and explore their place within it. Rancho El Chorro Outdoor School is "hands-on learning"--environmental education at its best--and the Rancho El Chorro staff has been providing it for over 26 years. More than 130,000 school children have enjoyed and benefited from the Rancho El Chorro facilities and program, and have left with a new sense of wonder of the natural world.

San Luis Obispo Botanical Garden - (Connecting people with nature through education and exploration) From gardening practices to nature study to cooking classes and everything in between- the San Luis Obispo Botanical Garden offers a full range of engaging activities for adults, families and children of all ages. 


\section{Access Improvements}

The primary improvements in the Byway corridor are related to improving access. This section identifies corridor planned and completed improvements that will allow all users to gain better access and increase education of the corridor's intrinsic qualities. Access improvements will include on and off-highway bicycle facilities, pedestrian trails and boardwalks, and scenic vista points and staging areas. Many of these projects will include interpretive elements to enhance their experience. Together, it is planned that visitors will have unsurpassed access to experience and explore the sites and activity centers of the corridor.

\section{Bicycle and Pedestrian Improvements} The Byway corridor offers incredible opportunities for bicycling. The Byway is a part of the Pacific Coast Bike Route and California Coastal Trail. It is also showcased in many cycling events such as the Slabtown Rollers' Country Coast Classic Bike Ride, Best Buddies Challenge, and the Mazda Foundation Million Dollar Challenge. In 2005, The AMGEN Tour of California began annually including the Byway in the official cyclist route. The Byway also offers a variety of rides in a number of different landscapes and terrain for all types of cyclists.

\section{San Luis Obispo County, the City of Morro} Bay, Caltrans, and SLOCOG have all included improvements to the corridor's non-motorized transportation system in their adopted plans with the vision of an integrated local and regional system. This system is composed of Class I, II, and III bikeways, and pedestrian boardwalks that will enable people to safely bicycle for both commuting and recreation purposes.

Highway 1 is a popular route for dedicated cyclists who ride long distances on the Central Coast. Many even ride the entire stretch between San Luis Obispo and Monterey. The very narrow and circuitous traverse along the cliffs of the Santa Lucia Range becomes a problem for novice riders in the northern area of the corridor, however, widening the highway south to San Carpoforo Creek is likely to be geologically, environmentally, and/or financially infeasible. Increasing opportunities for non-motorized modes of transportation is a primary goal of the San Luis Obispo Council of Governments, which is reflected in its Regional Transportation Plan (RTP). The plan identifies opportunities for further improving bicycle and pedestrian opportunities through the corridor with the development of a multi-use trail system off the state highway system where feasible. When complete, this system will offer residents and visitors an uninterrupted scenic experience through the human and natural communities of the corridor and compliment the stated objectives of the California Coastal Trail.

\section{Highway}

The scenic Byway corridor is heavily used by bicyclists, drawing cyclists from around the country, and around the world. Improving the highway for these users is an important goal for safety and access. Highway 1 has adequate shoulders through the majority of the Byway corridor. However, shoulders become very narrow or are absent in the northern reaches of the corridor (north of San Carporforo Creek PM 71.5 ) as the highway enters the very narrow and circuitous traverse along the cliffs of the Santa Lucia Range. Also, Caltrans has been working to improve the shoulders to 4 feet and has made significant progress north of Hearst Castle in recent years. The Piedras Blancas Realignment has been funded and will relocate 2.8 miles of the highway subject to bluff erosion approximately 475 feet east of the existing corridor. This presents an opportunity for integrating the Coastal Trail along the existing corridor. South of Hearst Castle, shoulders vary between 8 and 10 feet.

However, the Toro Creek Bridge in Morro Bay (PM 32.6) has been one area of concern due to a lack of shoulders on the southbound structure. The northbound bridge structure lacks shoulders, forcing cyclists to share the mainline with motorized vehicles in a relatively high-speed area.

\section{Off-Highway}

Improved

A primary objective for the corridor is to improve the off-highway access for cyclists and pedestrians. While 
many of the more experienced cyclists will choose to continue using the highway's shoulders rather than off-highway alternatives, most travelers would prefer to have opportunities to be separated from motorized traffic to enjoy the corridor.

To improve opportunities for these users, a network of off-highway non-motorized facilities is planned (see the maps at the end of this chapter).

Class I Multi-use paths - County and regional plans call for class I paths in areas of the Highway 1 corridor that lack parallel routes. Areas that are planned to have class I paths include Cal Poly to Cuesta College, Cuesta College to Morro Bay, and Morro Bay to Cayucos. The projects will link Morro Bay and Cayucos, which are currently connected only via Highway 1. The addition of the connector will provide an off-highway alternative for non-motorized travelers, as well as dramatically improve coastal and recreational access along the most utilized beach in the corridor.

Pedestrian Boardwalks - There have been six pedestrian boardwalks constructed since 2000 in the corridor and others are planned. The construction of the boardwalks has resulted in both access to, and protection of the resources they serve. Existing boardwalks in the Byway corridor include Elfin Forest in Los Osos, Morro Bay Marina, Morro Bay Harbor walk, Moonstone Beach Boardwalk in Cambria, and at two boardwalks at Elephant Seal Beach north of Point Piedras Blancas.

Unimproved - There are a number of opportunities for visitors to the Byway corridor to get off the beaten path onto unimproved hiking/biking trails. The following list identifies some of the trail systems available to the public in the Byway corridor:

- Bishop Peak Natural Reserve

- El Chorro Regional Park

- Montaña de Oro State Park

- Morro Bay State Park

- Morro Strand State Beach

- Estero Bluffs

- Harmony Headlands State Park
- Fiscalini Ranch

- San Simeon State Park

- San Simeon Sate Park North

The areas and the opportunities to expand these opportunities have grown tremendously in recent years with the increase in property acquisitions that have taken place in the corridor. Caltrans secured approximately 18 miles of Hearst property west of Highway 1 in 2004 as a part of the Hearst Ranch scenic conservation easement. This acquisition, coupled with others, is rapidly making the vision of a continuous California Coastal Trail segment (CCT) in the Byway corridor a feasible opportunity in the foreseeable future. Subsequent to this Caltrans purchase, the land was transferred to the California Department of Parks and Recreation (DPR) to manage access and resources.

DPR has since developed interim guidelines for the management of the property. These guidelines, developed with substantial public involvement, provide initial steps that DPR has in implementing the CCT on this remarkable property. The guidelines show plans for both vertical and lateral access of the trail, as well as connections to vehicle access points. Working directly with DPR, stakeholders of the North Coast Byway will provide valuable input in the ultimate management of the North Coast Acquisition.

\section{Scenic Vista Points}

The corridor has over a dozen formal and informal pullouts/scenic vista points. Most of the areas are informal and unimproved. Improvement of some of these sites into access points staging areas or wayward exhibits is a goal of the DCP to be achieved over time. Improvements of these sites would include paving, interpretive elements, and access to resources. The improvement of these vista points will provide opportunities to improve visitor access and education. Which sites to improve, which to consolidate, and which to leave will be part of a more specific effort in coming years. For informational purposes, an inventory of these locations is included in Appendix F. 
The California Department of Transportation (Caltrans) is responsible for ensuring the condition and operation of state highway facilities as well as developing improvements where needed. These improvement projects are identified and largely funded through the State Highway Operations and Protection Program (SHOPP). Types of projects identified in the SHOPP that address safety improvements include median barriers, turnchannelization projects, bridge replacements, and improvement of bridges and rail bridges.

The California Coastal Act has a provision that north of Cayucos Highway 1 will be maintained as a two lane conventional highway outside of urban reserve lines. Planned improvements to the Highway 1 corridor are primarily associated with maintaining and enhancing the existing system. Examples of planned improvements include signalization where warrants are met, scenic pullouts, left and right turn channelization and passing lanes where appropriate and necessary. These improvements are designed to maintain adequate operations of the highway for residents and visitors, while also preserving the rural character of the area, a stated policy of local land use plans.

Improvements envisioned for the corridor include enhancement projects such as completion of pedestrian and bicycle facilities, applying community sensitive design, and developing amenities, such as landscaping beautification and scenic pullout projects. A realignment of the highway is planned for the highway north of San Simeon from approximately the Piedras Blancas Lighthouse to Arroyo de La Cruz (approximately 5 miles). This realignment is planned in response to the continued erosion of the coastline which is a continuing threat to the highway's operations. Currently there are a number of alternatives for the realignment that would align the corridor to varying degree to the east. 
The beautification of the Byway is part of an ongoing regional effort to reduce the impact roads have on the communities and enhance the traveler's experience. To enhance the beauty of the highway corridor, improvements to infrastructure are planned and encouraged. They include:

- Gateway monuments

- Sensitive fencing treatments

- Textured crosswalks

- Landscaping beautification

- Sensitive sign placement

- Billboard removal

- Aesthetic railings that provide the Byway user protection but are esthetically pleasing

- Removal of non-native plant species

- Conservation easements

- Utilities Undergrounding

A listing of the improvements by corridor zone are included in this chapter.

\section{Utilities Undergrounding}

One of the major highway beautification

enhancements is utilities undergrounding. Overhead utilities, prevalent in some areas of the corridor, detract from some of the scenic viewshed along the corridor. The Scenic Byway Committee will prioritize the undergrounding of utilities for implementation of projects, and others identified in the plan. To be implemented, all enhancement projects on private property identified in this plan would require full agreement by funding agencies and property owners.

\section{Billboard Removal}

The Byway has several billboards along this route that advertise commercial uses which detracts from the scenic view shed, community character, and the rural nature of the area around the highway. The Scenic Byway Committee will prioritize the removal of these billboards for implementation. These billboard are privately owned therefore removal will require approval of their owners. Funding to reimburse these owners for loss of income caused by the removal of their billboard will likely be the required. Another option for billboard removal would be to condition its removal if the property owner applies for a discretionary permit through the County or Cities permit process.

\section{Conservation Easements}

Acquiring conservation easements is also a way to protect the viewshed of the Byway. SLOCOG assisted in the acquisition of the San Geronimo Ranch conservation easement, consisting of approximately 900 acres. The easement is bordered by Highway 1 as well as the Estero Bluffs State Park for approximately 2 miles. Easements like this one, limits new development, subdivision, and visibility of new structures from Highway 1. As part of a comprehensive effort to preserve the visual quality of the corridor, Caltrans holds a Scenic Conservation Easement over much of the land west of Highway 2 between Pico Point and Ragged Point. 


\section{IMPROVEMENT PROJECTS}

\section{Corridor Wide}

Corridor-wide priorities in the short and mid-term will include:

\begin{tabular}{|l|c|c|c|}
\hline \multicolumn{1}{|c|}{ Corridor Wide Priorities } & Planned & Funded & Completed \\
\hline Byway Branding Implementation- Design Byway logo & & & X \\
\hline Design Comprehensive Interpretive Signage Plan & & & X \\
\hline Implement Byway and Interpretive Signage Plan & & X & \\
\hline Design Byway Gateway Program & & X & \\
\hline Comprehensive Scenic Viewshed Preservation Plan & X & & \\
\hline Utilities Undergrounding & X & & \\
\hline $\begin{array}{l}\text { Aesthetic Improvements: Landscaping, Aesthetics } \\
\text { bridge railings }\end{array}$ & $\mathrm{X}$ & & \\
\hline
\end{tabular}

\section{San Simeon North Segment}

The highest priorities in the short and mid-term for this northern most segment will be the realignment of Highway 1 at Piedras Blancas, the development of the California Coastal Trail, and improving select vista points for improvement to wayside exhibits

\begin{tabular}{|c|c|c|c|}
\hline San Simeon North Projects & Planned & Funded & Completed \\
\hline \multicolumn{4}{|l|}{ Interpretation/Byway Signage } \\
\hline Interpretive Elements at Key Locations & & $\mathrm{X}$ & \\
\hline Improve Overlook to Wayside Exhibit & $\mathrm{X}$ & & \\
\hline Byway Highway Signs and Logos & & $\mathrm{X}$ & \\
\hline \multicolumn{4}{|l|}{ Community Enhancements } \\
\hline San Simeon Gateway Monument & & $\mathrm{X}$ & \\
\hline \multicolumn{4}{|l|}{ Access Improvements } \\
\hline San Simeon Creek/ Washburn Boardwalk & & & $\mathrm{X}$ \\
\hline California Coastal Trail & $\mathrm{X}$ & & \\
\hline Beach Access at Key Locations & $\mathrm{X}$ & & \\
\hline Route I Roadside Recreational Facilities & $\mathrm{X}$ & & \\
\hline \multicolumn{4}{|l|}{ Safety and Operational Improvements } \\
\hline Highway 1 Realignment (Piedras Blancas) & $\mathrm{X}$ & $\mathrm{X}$ & \\
\hline San Simeon Circulation Enhancements & $\mathrm{X}$ & & \\
\hline Weymouth Street at SR 1 Traffic Signal and Channelization & $\mathrm{X}$ & & \\
\hline $\begin{array}{l}\text { Windsor Blvd. at Main Street at SR } 1 \text { Traffic Signal for } \\
\text { Frontage Rd. }\end{array}$ & $\mathrm{X}$ & $\mathrm{X}$ & \\
\hline
\end{tabular}




\section{Harmony Valley}

The highest priorities in the short and mid-term in the Harmony Valley Segment will be removing billboards and utility undergrounding.

\begin{tabular}{|l|c|c|c|}
\hline \multicolumn{1}{|c|}{ Harmony Valley Projects } & Planned & Funded & Completed \\
\hline Interpretation/Byway Signage & & $\mathrm{X}$ & \\
\hline Interpretive Elements at Key Locations & & $\mathrm{X}$ & \\
\hline Byway Highway Signs and Logos & & $\mathrm{X}$ & \\
\hline Community Enhancements & & & \\
\hline Cambria Gateway Monument & $\mathrm{X}$ & & \\
\hline Billboard Removal (willing sellers) & $\mathrm{X}$ & & $\mathrm{X}$ \\
\hline Utility Undergrounding (willing sellers) & & & $\mathrm{X}$ \\
\hline Access Improvements & & & \\
\hline Overlook/Staging Area (Fiscalini Ranch) & & & \\
\hline Safety and Operational Improvements & & & \\
\hline Harmony Left-turn Channelization & & & \\
\hline
\end{tabular}

\section{Estero Bay}

The highest priorities in the short and mid-term in the Estero Bay Segment will be providing off-highway facilities for non-motorized travelers to provide access to views and recreational opportunities. Coupled with those projects will be interpretive elements. Also, an emphasis will be placed on improving fencing, landscaping, and highway ramps that enhance the North Main Area of Morro Bay.

\begin{tabular}{|l|c|c|c|}
\hline \multicolumn{1}{|c|}{ Estero Bay Projects } & Planned & Funded & Completed \\
\hline Interpretation/Byway Signage & & $X$ & \\
\hline Interpretive Elements at Key Locations & & $X$ & \\
\hline Byway Highway Signs and Logos & & X
\end{tabular}

\section{Community Enhancements}

\begin{tabular}{|l|l|l|l|}
\hline Morro Bay Highway 1 Enhancements & X & & \\
\hline Morro Bay Gateway Monuments & X & & \\
\hline Improve Fencing and Landscaping & X & & \\
\hline
\end{tabular}

Access Improvements

Morro Bay Harbor Walk

Morro Bay - Cayucos Connector

Morro Bay State Park Marina Boardwalk

Estero Bluffs Improvements - Vista Points and Access

East/ West Subterranean Highway Crossings

Morro Bay Harborwalk Extension \& Morro Creek Bridge

Hwy 1 Bridge over Toro Creek Add Bicycle Lanes and

Aesthetic Bridge Railings

Improved Beach Access at North Point

Cayucos Bike Improvements

Toro Creek Rd. over Toro Creek, Bridge No. 49C0384 


\section{Morros/ Chorro Valley}

The highest priorities in the short and mid-term in the Morros Segment were installing gateway signs/ monuments for San Luis Obispo and Morro Bay, as well as Byway signage (logos). There is also a need for a scenic overlook/interpretive area in segment. Further, there is a desire to mitigate/remove structures/areas that detract from the scenic vistas. Developing the Chorro Valley Trail is a high priority for the area.

\begin{tabular}{|c|c|c|c|}
\hline Morros/Chorro Valley Projects & Planned & Funded & Completed \\
\hline \multicolumn{4}{|l|}{ Interpretation/Byway Signage } \\
\hline Interpretive Elements at Key Locations & $\mathrm{X}$ & $\mathrm{X}$ & \\
\hline Byway Highway Signs and Logos & & $\mathrm{X}$ & \\
\hline Interpretation Signage & $\mathrm{X}$ & $\mathrm{X}$ & \\
\hline \multicolumn{4}{|l|}{ Community Enhancements } \\
\hline San Luis Obispo Community Gateway Monument & & $\mathrm{X}$ & \\
\hline Highway Screening & $\mathrm{X}$ & & \\
\hline Billboard Removal (willing sellers) & $\mathrm{X}$ & & \\
\hline \multicolumn{4}{|l|}{ Access Improvements } \\
\hline Vista Overlook (Morros) & $\mathrm{X}$ & & \\
\hline Chorro Valley Trail & $\bar{X}$ & & \\
\hline
\end{tabular}




\section{San Simeon North}

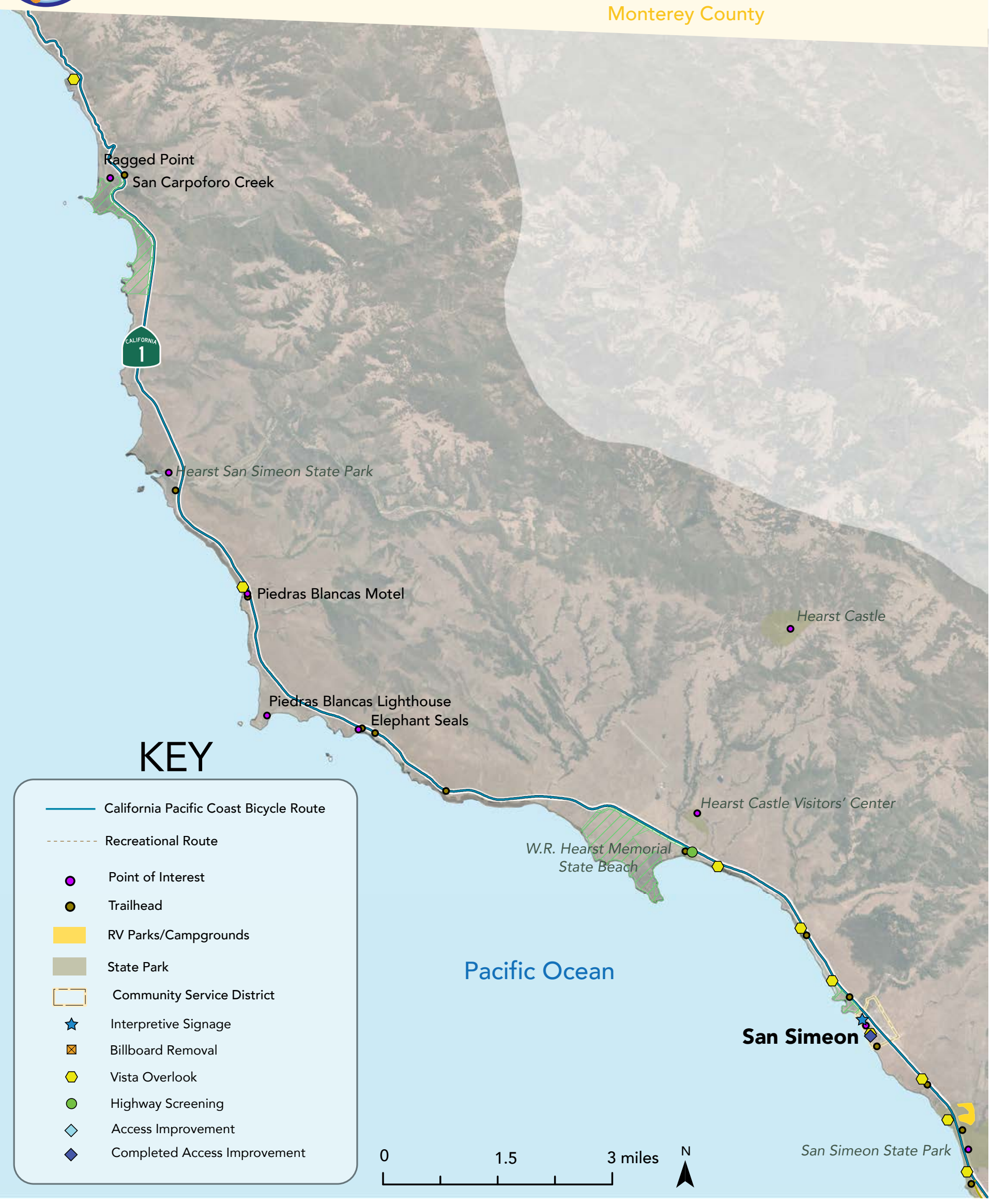




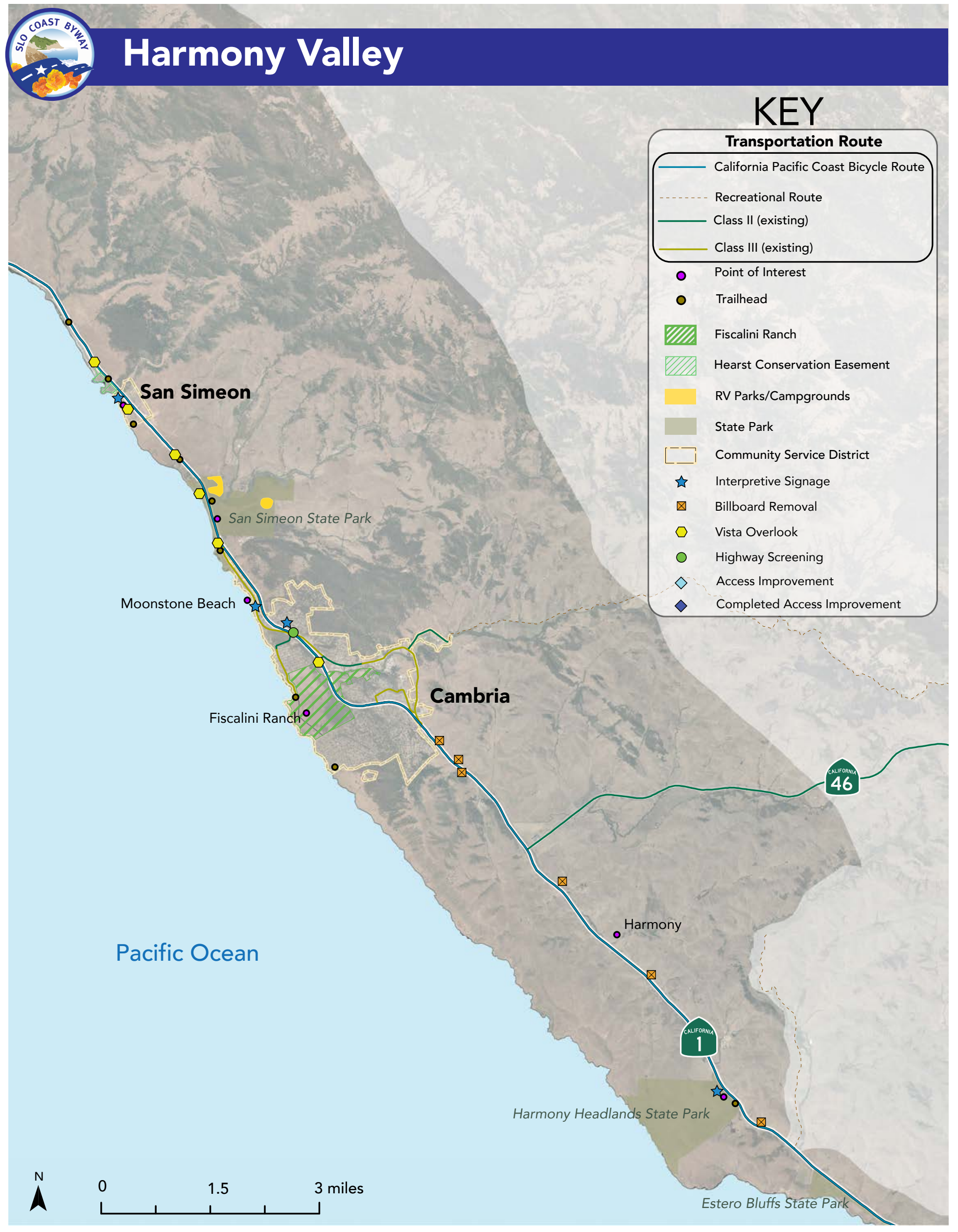




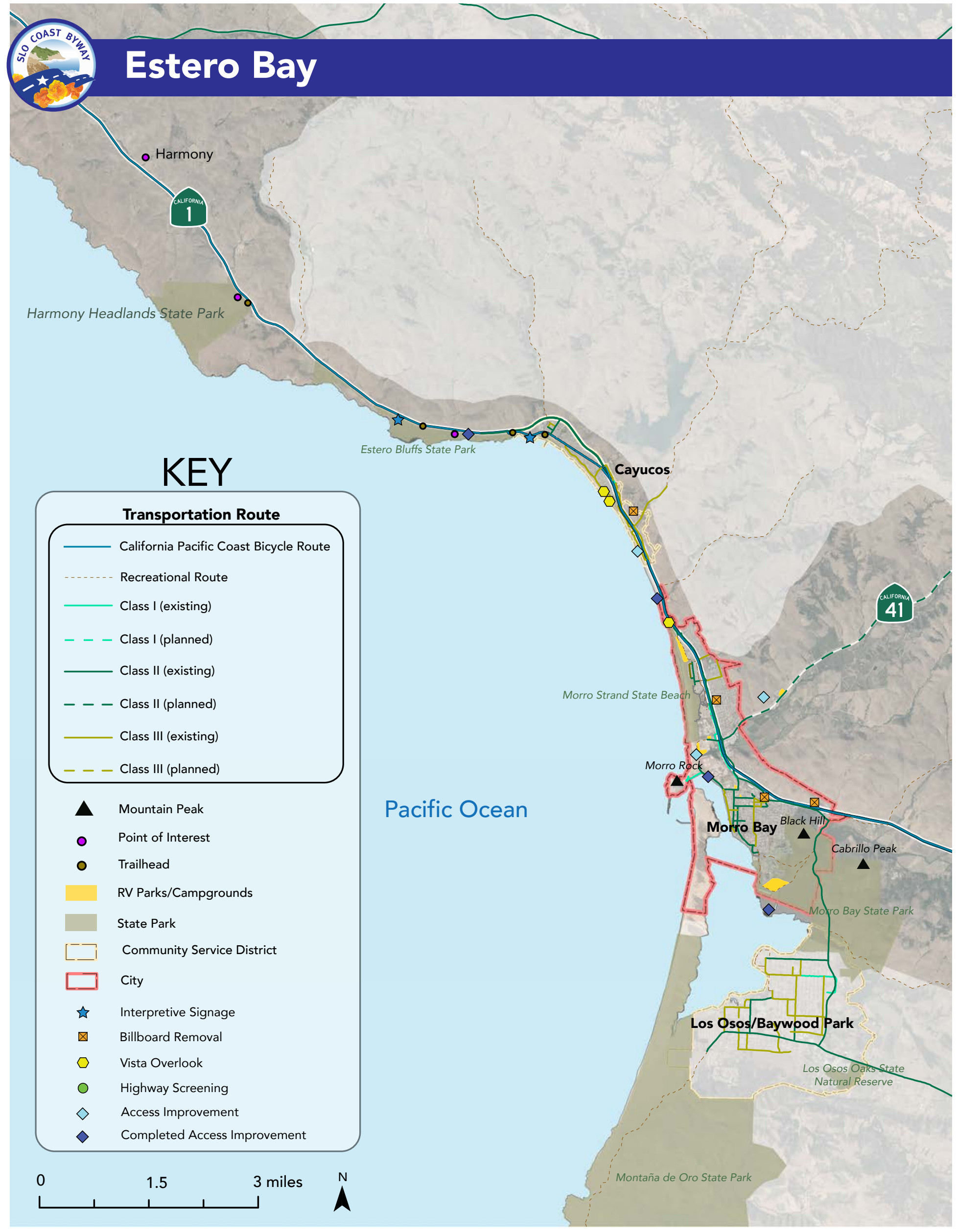




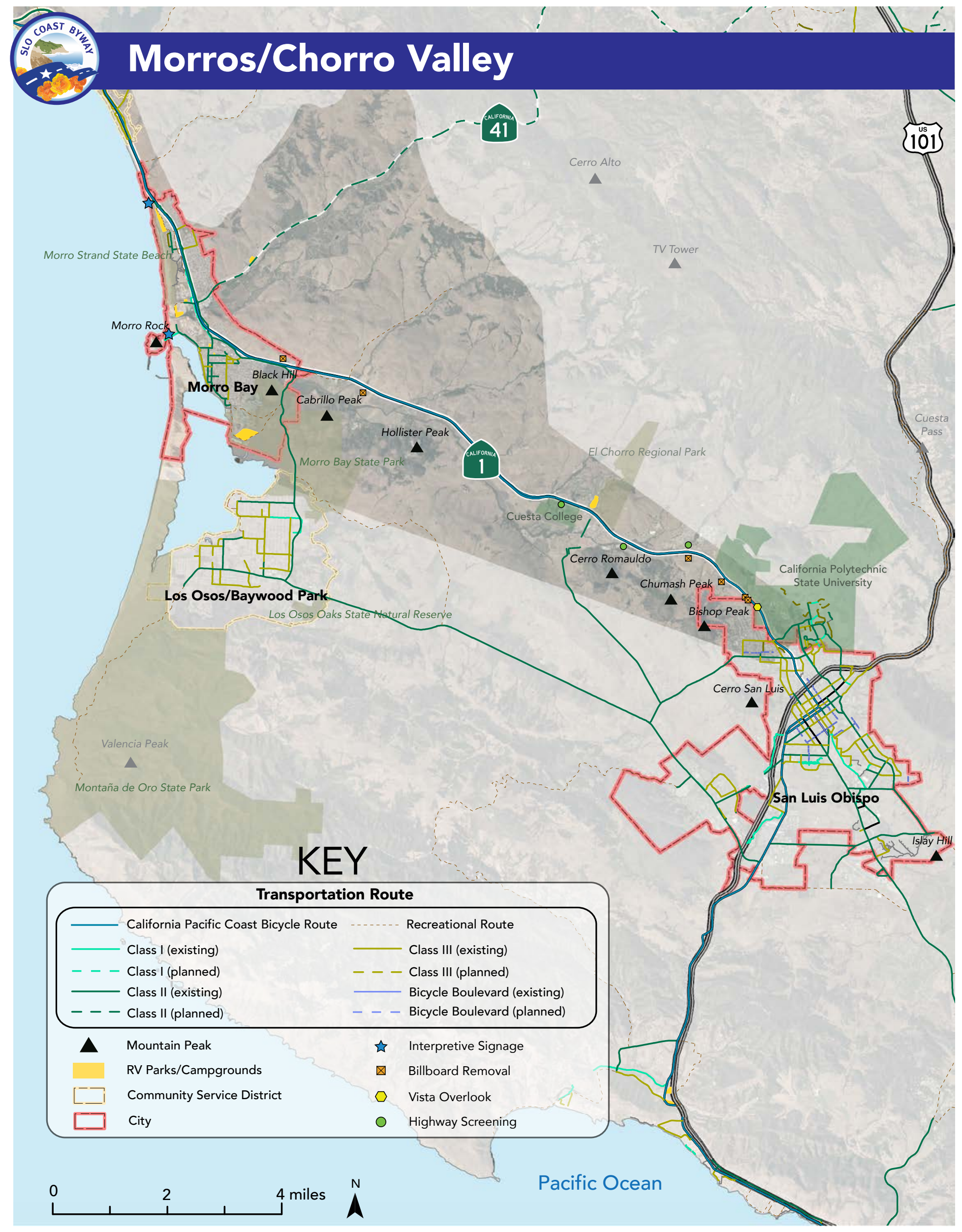




\section{CHAPTER 3 \\ PLAN ADMINISTRATION AND PROJECT IMPLEMENTATION}

- Plan Update Process

- Funding for Improvements

- Technical Assistance

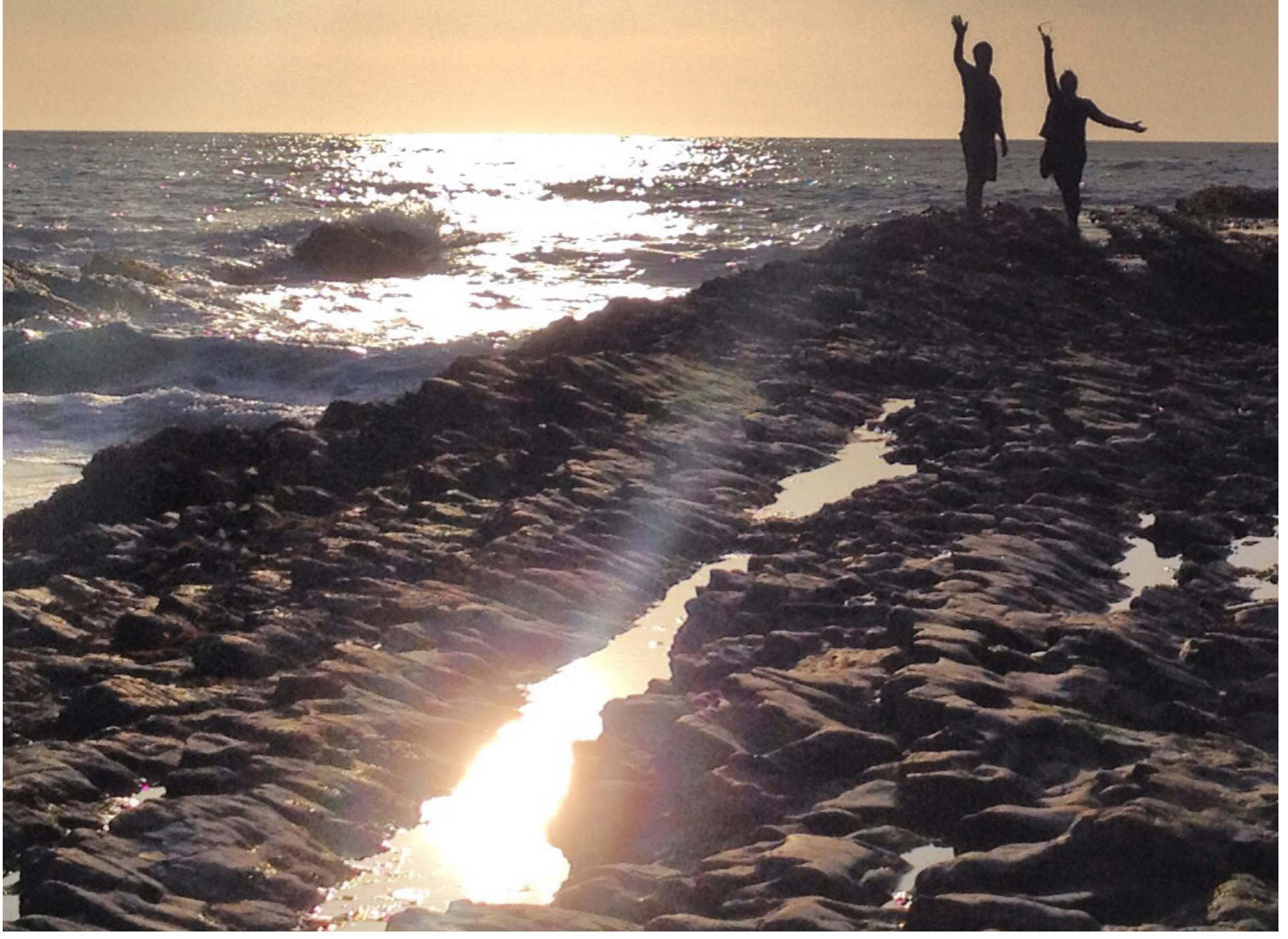




\section{PLAN UPDATE PROCESS}

This SBCP is intended to evolve and be modified over time. It has been developed in collaboration with the state and local jurisdictions to reflect their policies and interests and ultimately respond to changes in local jurisdiction involvement, public priorities, and new financial information.

Monitoring of the overall effectiveness and success of the Scenic Byway Corridor Plan is essential. Regularly scheduled triennial review of the plan will allow it to respond to the needs of local jurisdictions and the state. The Byway Advisory Committee may elect to schedule more frequent reviews to address exceptional circumstances, or respond to a jurisdiction's request for plan modifications. To make changes, amendments or corrections to the enhancement plan, the agencies involved in managing the Byway will need to take the steps outlined in this section.

\section{Plan Update Responsibilities} SLOCOG and the Byway Advisory Committee voting membership will be active partners in the ongoing management of the BCP. SLOCOG, with input from the North Coast Scenic Byway Advisory Committee, will serve as the principal decisionmaking body for the Byway Plan and Program, consistent with its authority and in collaboration with local and state jurisdictions. Major authorities within the Byway corridor include:

- California Department of Transportation (Caltrans)

- City of Morro Bay

- County of San Luis Obispo

- California Department of Parks and Recreation

- California Coastal Commission

SLOCOG staff will facilitate and provide administration and oversight of the plan and the update process.
Update and amendment factors for consideration will include:

1. Adding or promoting features (i.e. Intrinsic Qualities) and/or strategies;

2. Deleting or demoting features and/or strategies;

3. Adding or significantly modifying projects

\section{Review}

The designated decision-making body, SLOCOG, will schedule a periodic Scenic Byway Corridor Plan review. The goals and objectives of the Scenic Byway Corridor Plan will be reviewed by SLOCOG, Caltrans, and other jurisdictional stakeholders to ensure that they still meet the state and jurisdiction vision for the corridor as a scenic Byway. The direction and projects within the plan will be reviewed to ensure their relevance to and consistency with the goals and objectives of the plan. SLOCOG will incorporate any changes in goals, objectives, and procedures into the enhancement plan. 
A variety of potential sources of funding are available for the implementation of projects. Some examples are as follows.

\section{Federal Highway Administration (FHWA) Funding Programs}

The following programs were reauthorized under Moving Ahead for Progress in the 21st Century Act (MAP-21) which is a two-year funding program approved in July 2012 by congressional action.

\section{Surface Transportation Program (STP) / State Highway Account (SHA)}

The Surface Transportation Program (STP) provides flexible funding that may be used by States and localities for projects on any Federal-aid highway, including the National Highway System, bridge projects on any public road (not classified as local or rural minor collectors), transit capital projects, and intra-city and intercity bus terminals and facilities. The federal share for STP funds is generally 80 percent, subject to the sliding scale adjustment. A rural allocation is directly allocated to all counties (included within the Base amount). Historically, SLOCOG's STP funds have been exchanged with the State for State Highway Account (SHA) funds. The advantage of this exchange is that the revenue is no longer subject to federal regulations. This allows the cities and county to significantly reduce the amount of time and cost required to build a transportation project by having only to meet state and local regulations. The disadvantage of exchanging the revenue is that the use of the revenue becomes less flexible. The SHA funds are subject to the restrictions of Article 19 of the State Constitution and can only be used on Surface Transportation projects.

This revenue stream is currently the most flexible of SLOCOG's funding sources and is assumed stable. Typical projects funded in this program include: roadways, bridges, transit capital, bicycle, and pedestrian projects. This revenue stream is allocated to the region on a formula basis.
Transportation Alternatives Program (TAP) In MAP-21, Congress changed the Transportation Enhancements program and other non- motorized transportation programs, compromising between the positions of groups that wanted more funding for these programs and groups that wanted to eliminate these programs entirely. The compromise eliminated certain types of activities from the list of eligible transportation enhancements, renamed the transportation enhancements group of activities "transportation alternatives," and combined this group of activities with the former Recreational Trails and Safe Routes to Schools programs under one umbrella program called Transportation Alternatives Program (TAP). The TAP provides funding for programs and projects defined as transportation alternatives, including on- and off-road pedestrian and bicycle facilities, infrastructure projects for improving nondriver access to public transportation and enhanced mobility, community improvement activities, and environmental mitigation; recreational trail program projects; safe routes to school projects; and projects for planning, designing, or constructing boulevards and other roadways largely in the right-of-way or former Interstate System routes or other divided highways.

The State of California has also developed a new fund program: Active Transportation Program (ATP). Since the TAP funds are included within the State's ATP, funds from the TAP will be accounted for in the ATP. This program is discussed in the next section.

\section{State Funding Programs}

\section{Active Transportation Program (ATP)}

Active transportation involves the traveler being physically active, such as by biking or walking to a destination. Increasing the use of active transportation as a mode of travel can have several benefits, such as: improving health and relieving congestion. The following programs were identified to fund and support active transportation projects. The 2013-14 State Budget consolidated these programs into a single active transportation program administered by Caltrans. 
- Transportation Alternatives Program (TAP). The TAP (previous RTPs include Transportation Enhancements) is a federally funded grant program administered by Caltrans. The program funds various projects such as bicycle lanes, pedestrian improvements, and recreational trails.

- Environmental Enhancement Mitigation Program. The Environmental Enhancement Mitigation Program, which is administered by the state's Natural Resources Agency, primarily funds roadway landscaping, roadside recreation, and environmental enhancements. The program also funds bicycle infrastructure projects, such as building bicycle paths.

Regional Transportation Improvement Program (RTIP) - Highway Improvements

SB 45 (1997) amended state statute giving significant local control over the programming of the $75 \%$ of the State Highway Account funds that flow into the State Transportation Improvement Program (STIP). In 2002 and before, the San Luis Obispo RTIP received approximately $\$ 7.5 \mathrm{M} / \mathrm{yr}$ from the State fuel-taxfunded State Highway Account (as well as $\$ 7.5 \mathrm{M} / \mathrm{yr}$ from the federal fuel tax). The Fuel Tax Swap of 2010 eliminated Proposition 42 (2002) provisions, and now the RTIP is solely funded by state's variable fuel excise tax. After paying for Transportation Debt Services, the STIP receives $44 \%$ of revenues collected.

RTIP funds are the region's primary source of funding Highway improvements. Allowable uses also include: capital improvement projects including local roads, public transit (including buses), pedestrian and bicycle facilities, grade separations, transportation system management, transportation demand management, sound walls, inter-modal facilities and safety.

\section{Electric Undergrounding Program}

Under the provisions of the company's Rule 20A, an electric tariff filed with the California Public Utilities Commission, PG\&E places 30 miles of overhead electric facilities underground within its service area. Projects performed under Rule 20A are nominated by a city, county or municipal agency and discussed with
Pacific Gas and Electric Company, as well as other utilities. The costs for undergrounding under Rule 20A are recovered through electric rates after the project is completed. ${ }^{17}$

\section{State Highway Operation and Protection} Program (SHOPP)

As owner and operator, Caltrans is responsible for maintaining, operating, and preserving the State Highway System (SHS). The purpose of the SHOPP is to maintain and preserve the investment in the SHS and its supporting infrastructure. The SHS consists of 50,000 lane miles of pavement, 12,559 bridges, 205,000 culverts and drainage facilities, 87 roadside rest areas and 29,183 acres of roadside landscaping. There are 440 support facilities, including equipment shops, maintenance stations, transportation materials laboratories, and testing facilities. Candidate projects that meet specific SHOPP program criteria are identified in the 10-year SHOPP plan. The financially constrained 10-year SHOPP reflects the expected revenues for the program. Caltrans then nominates the highest priority projects to compete statewide to be programmed in the four-year SHOPP. Projects along the corridor eligible for funding include: bridge rails, realignments, roadway and roadside preservation. An example of an realignment project on Route 1 is the Piedras Blancas Realignment project. This project has been funded and will relocate 2.8 miles of the highway subject to bluff erosion approximately 475 feet east of the existing corridor.

\section{Local Funding Sources}

Local revenue sources are classified as either general purpose or special purpose. General purpose revenues - which include various taxes, fees, rates, and fines flow directly into a jurisdiction's General Fund, such as sales and use taxes, locally imposed general taxes, and business license fees. Local jurisdictions may choose to use general fund moneys to help finance transportation projects or services, or as local matching funds for transportation grants. 
In addition to local city and county planning offices, the following organizations and agencies can provide information and technical services to assist in interpreting and protecting scenic, natural, archaeological, historic, cultural, and recreational resources related to this plan.

- Scenic America

- The Trust for Public Land

- The Nature Conservancy

- National Scenic Byways Clearinghouse

- Coast to Coast Interpreters League

- California Coastal Conservancy

\section{Agencies}

- Federal Highway Administration (FWHA)

- California Department of Transportation (Caltrans)

- California Department of Resources

- California Department of Parks and Recreation

- California Department of Fish and Game

- National Parks Service

- U.S. Forest Service

- U.S. Fish and Wildlife Service

- Bureau of Land Management

- Monterey Bay National Marine Sanctuary (NOAA)

- Morro Bay National Estuary Program (EPA)

\section{Designation Removal}

Jurisdictions can choose at any time to be removed from the designated National Scenic Byway, if the original conditions of their participation change. A biennial review process is also available to any jurisdiction that wants to be de-designated for other reasons. Both of these processes are described in further detail.

Under the following conditions jurisdictions may decide to be removed from the enhancement plan at any time. FHWA changes regulations and/or SLOCOG/Caltrans changes its approach to managing Highway 1 as a National Scenic Byway as documented in the Scenic Byway Corridor Plan Under these conditions, the following steps must be taken:

1. A city or county representative sends notification to SLOCOG. The notification should include the rationale for the decision to be removed and describe regional or plan impacts of that decision.

2. Upon receipt of the notification, a de-designation review meeting is set up and attended by the local jurisdiction (and, in the case of a city, the county within which the city is located), Scenic Byway Committee, representatives, SLOCOG, Caltrans, and FHWA.

3. This group will review the reasons for the notice and document them.

4. If the jurisdiction's concerns cannot be resolved through this dialogue, SLOCOG will formally notify FHWA that the jurisdiction is no longer a part of the official National Scenic Byway corridor. SLOCOG will also amend the Scenic Byway Corridor Plan to document the change. Amendments will initially be in the form of addendums. The full plan will be updated, with addendums, no less frequently than every 4 years. 


\section{CHAPTER 4 ECONOMIC BENEFITS}

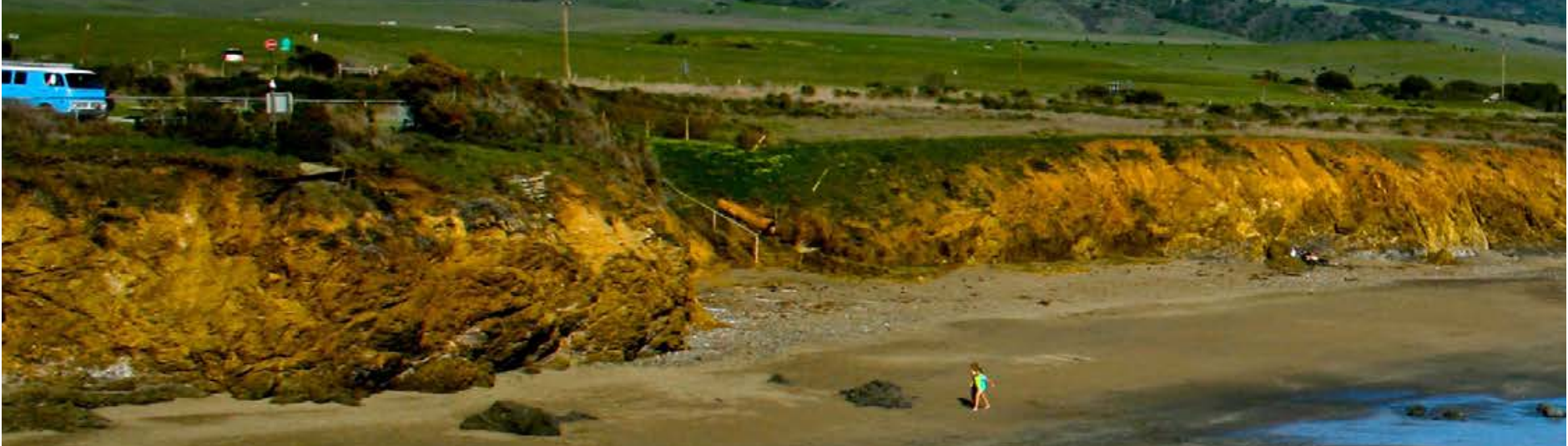

H 


\section{ECONOMIC BENEFITS}

\section{INTRODUCTION}

During this update, a brief economic analysis was performed on the Byway area. The main sources of information for the economic analysis were the San Luis Obispo Economic Vitality Corporation's 2008 Tourism Report, Dean Runyan Associates' California Travel Impacts, JBG Consulting's 2011 Economic Appraisal: The Mid-Coast of San Luis Obispo County Estero Bay Scenic Byway Trail, and San Luis Obispo County Appraiser Reports. The information found through these sources were then used in the America's Byways Resource Center's Economic Impact Tool. This tool is a Microsoft Excel based economic modeling tool provided by the National Association of Development Organizations.

The 2008 SLO EVC Tourism Report divided the county into five economic regions, three of which are found along the North Coast Scenic Byway. According to the report, the communities along the Byway provided 50\% of the economic travel impacts for the county, which was the assumption used throughout the study. The analysis inputs were derived using $50 \%$ of the provided spending numbers found in the California Travel Impact Report. Assumptions and inputs can be seen in the Appendix G. The last Byway Plan Update took place in 2007, so it was decided that the base year of the analysis would be 2006 and the current year would be 2012 because it had the most recent and abundant data available. The analysis included the following communities: San Simeon, Cambria, Cayucos, Morro Bay, and San Luis Obispo.

\section{FINDINGS}

Between 2006 and 2012, the Country's economy was especially volatile. However, the County of San Luis Obispo continued to improve economically as a result of industries such as agriculture, construction, and tourism (Economic Outlook, 2013). This analysis focused on the economic impacts of tourism and was implemented to gain an understanding of the financial benefits of continuing to fund scenic projects. This understanding can be provided by an estimate of the Byway's current economic contribution.

As a result of this analysis, it is estimated that the Byway has positively contributed to the economy of San Luis Obispo County. Between 2006 and 2012, there was a net increase in number of travelers along the Byway equaling around 1.1 million people. It is estimated that visitation in this region has increased around $20 \%$. This trend of visitors was described in the SLO EVC's Tourism Impact Study, stating there would be an increase in daytrips and or intra-state overnight travel.

It is estimated that visitor spending has increased by $23 \%$ from over $\$ 500$ million in 2006 to almost $\$ 656$ million in 2012. It was also estimated that the Byway has a total impact of visitor spending of about $\$ 217,000$ with restaurants, retail, and lodging contributing to about $66 \%$ of the spending in 2012. The impacts in Figure 1 are separated into direct impacts, those resulting from the specific economic activities along the Byway, and indirect impacts, resulting from the effects of economic multipliers. Both direct and indirect impacts can be seen in Figure 1.

In six years, there has been a change in the Byway region's total employment with an increase of 52,043 jobs and it is estimated that $4.5 \%$ was a result of the Byway. The investments made along the Byway and the increase in visitors had positively impacted the 2012 employment in the region resulting in about 2,300 jobs. The investments made along the Byway can be seen in Appendix F. In the six years, there had been over $\$ 124$ million in capital improvements along the corridor that have been implemented and or funded. 


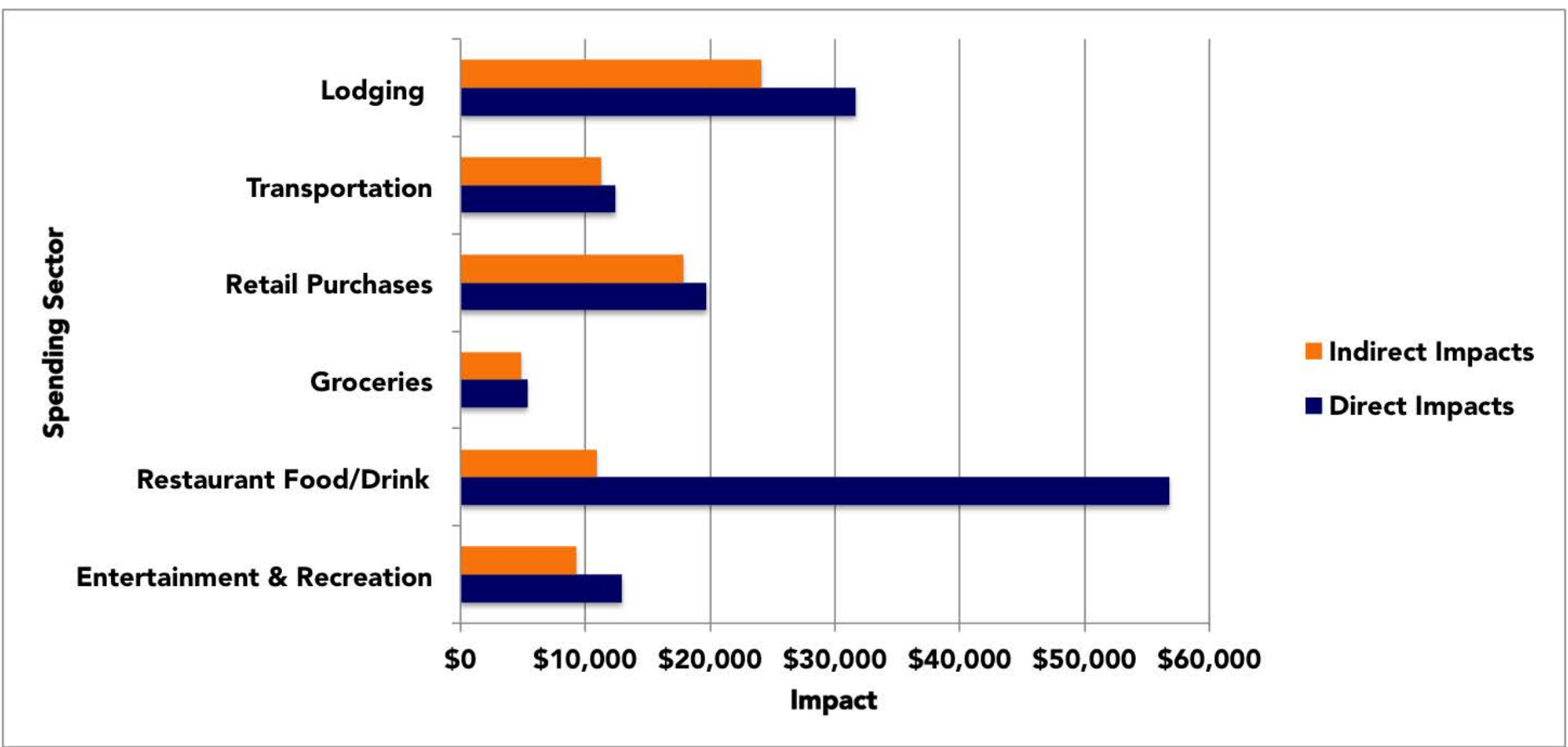

In conclusion these findings support the fact that leisure and hospitality continue to be a driving force in the County's economy. Tourism is an important part of our region's financial vitality and by providing opportunities, like the ability to access the North Coast Scenic Byway, the County will continue to offer residents and visitors an unparalleled experience. Continuing to improve and enhance the Byway experience is a viable investment for both scenic protection and the economy. 
1. Sierra Club - Santa Lucia Chapter. Morros (Nine Sisters) Preservation Fund. http://santalucia.sierraclub. org/morros.html

2. United States Forest Service. Southern California National Forests Plan Notice of Intent. Los Padres District. 2002.

3. Lathrop, Andrew. A Brief History of Mission San Luis Obispo De Tolosa. 1996. http://198.188.248.11/2982/history.htm

4. Robberts, Eddie. Chasing Mail Pouch Barns. http://museum.cl.msu.edu/barn/stories/story010/

5. California State Parks. Hearst Castle. http://www.beachcalifornia.com/hearst.html

6. United States Bureau of Land Management. Piedras Blancas Light Station Restoration Project Report. January 2002.

7. National Estuary Program. Environmental Protection Agency. Bringing Our Estuaries New Life http:// www.epa.gov/nep/text/capsule.htm\#morro

8. San Luis Obispo County Parks Division. Elfin Forest Natural Area Resource Management Plan. August 1997.

9. National Oceanic and Atmospheric Association. Monterey Bay National Marine Estuary. http://www. mbnms.nos.noaa.gov

10. Cayucos Land Conservancy. Is Your Way To Insure Open Space. http://www.cayucos.org/clc/

11. Radakovich, Milos. Elephant Seals of San Simeon. http://www.mbay.net/ milos/E_seals.htm

12. United States Department of the Interior, Bureau of Land Management, http://www.blm.gov/ca/pa/coastal_ monument/

13. About The Ranch, http://www.northcoastswap.org/ranch/history.htm

14. Sierra Club San Luis Obispo. One Earth, One Chance. Montana De Oro State Park. http://santalucia. sierraclub.org/mntdeoro.html

15. A Design Guide for Roadside Improvements, USDOT, FHWA, USDA Forest Service, July 2002.

16. Long Range Interpretive Plan, Monterey Bay Sanctuary Scenic Trail, Monterey Bay National Marine Sanctuary

17. PG\&E, (2014). Electric undergrounding program. [online] Pge.com. Available at: http://www.pge.com/ myhome/addservices/electricundergrounding/

18. America’s Byways, (2014). Photo \#54877: A Road Scene in Cambria | America's Byways. [online] Fhwa.dot. gov. Available at: http://www.fhwa.dot.gov/byways/photos/54877

19. Baird, M. (2005). The Nine Sisters Morros the-morros-9-sisters-5624. [online] Flickr. Available at: https:// www.flickr.com/photos/mikebaird/2296113377/

20. Baird, M. (2014). Estero Bluffs State Park, just north of Cayucos, CA, 10 October 2013.. [online] Flickr. Available at: http://www.flickr.com/photos/mikebaird/10234210144/

21. Liebgold, D. (2014). Trisha and Asher at Fiscalini Ranch. [online] Flickr. Available at: http://www.flickr. com/photos/dan-liebgold/4311108804/

22. Baird, M. (2011). Dudleya is a genus of succulent perennials, seen here in Harmony Headlands State Park 23 July 2011. [online] Flickr. Available at: http://www.flickr.com/photos/72825507@N00/5968511016

23. Ivan, (2006). Morro Bay Docks. [online] Commons.wikimedia.org. Available at: http://commons.wikimedia. org/wiki/File:Morro_Bay_Docks.jpg

24. Baird, M. (2011). L-R Betty, Ann. Kayak Morro Bay outing 30 Oct. 2011. [online] Flickr. Available at: http://www.flickr.com/photos/mikebaird/6296309718/

25. Historic Photos were generously provided by the San Luis Obispo County Historical Center 26. Google Maps. (2011). [San Simeon, California] [Street map]. 
27. Central Coast Economic Forecast, (2012). 2012 central coast economic forecast. Los Angeles: Beacon Economics.

28. County of San Luis Obispo, (2007). Tax rate information and assessed valuations 2006-2007. San Luis Obispo: Auditor-Controller Office.

29. County of San Luis Obispo, (2013). Tax rate information and assessed valuations 2012-2013. San Luis Obispo: Auditor-Controller Office.

30. Dean Runyan Associates, (2014). California Travel Impacts. [online] Deanrunyan.com. Available at: http:// www.deanrunyan.com/CATravelImpacts/CATravelImpacts.html [Accessed 20 Apr. 2014].

31. JBG Consulting, LLC, (2014). Economic Appraisal: The Mid-Coast of San Luis Obispo County, CA Estero Bay Scenic Byway Trail. San Luis Obispo, CA, pp.1-29.

32. San Luis Obispo Economic Vitality Corporation, (2008). SLO County Tourism Study. [online] SLO Tourism Report. Available at: http://www.sloevc.org/files/SLO\%20County\%20Tourism\%20 Report_2008\%20(v_2).pdf [Accessed 3 Feb. 2014]. 


\section{APPENDICES}

A) The SLO North Coast Scenic Byway Interpretive Signage Plan

B) Summary of framework of protections

C) County of San Luis Obispo Scenic Highway Corridor Protection Plan

D) San Luis Obispo County Coastal Plan Policies, Environmentally sensitive habitats

E) City of Morro Bay Scenic Highway corridor protection plan

F) Inventory of Overlooks

G) Economic Analysis Inputs and Assumptions

H) Public Comment 


\section{APPENDIX A}

The SLO North Coast Scenic Byway Interpretive Signage Plan 


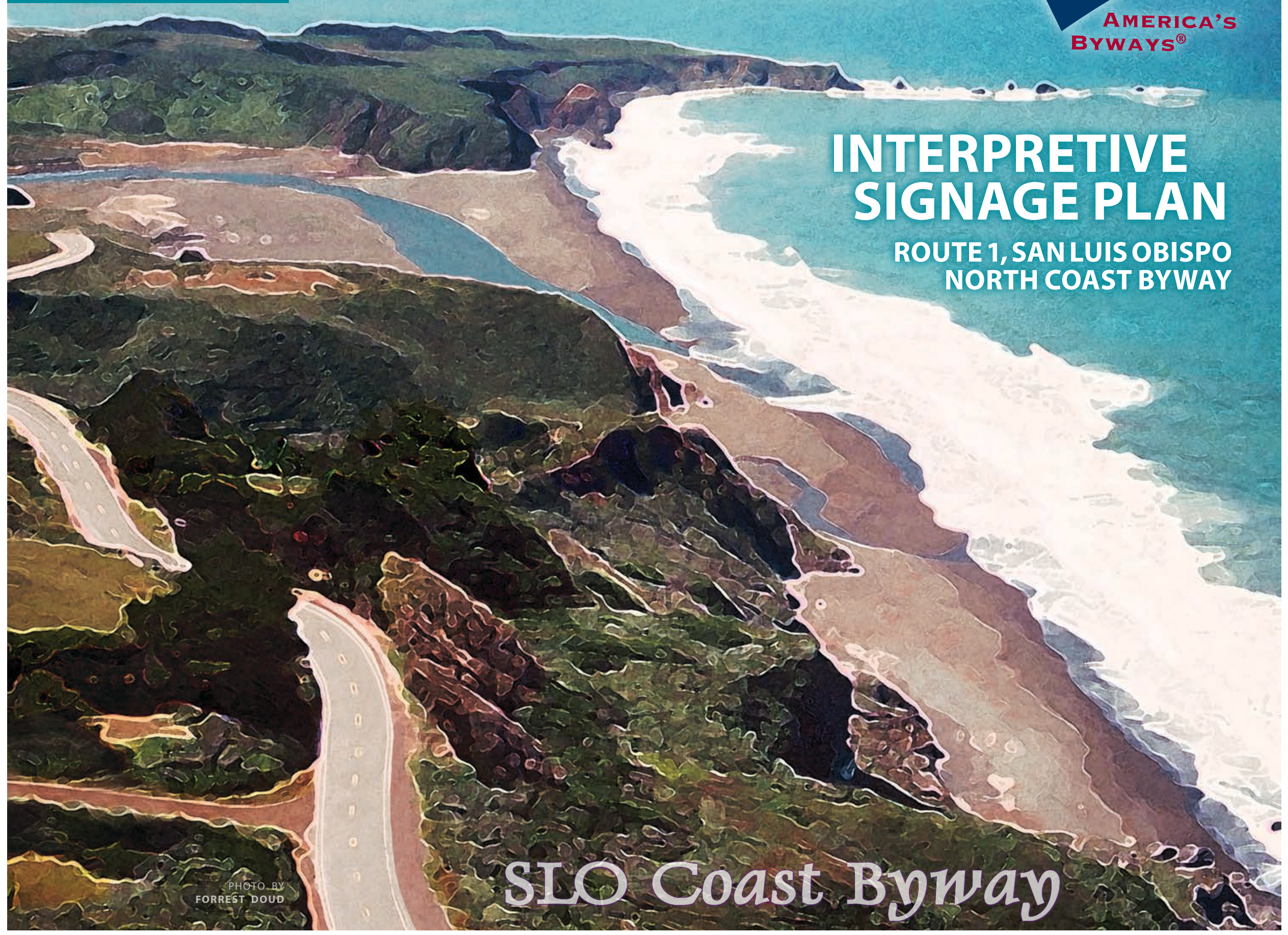




\section{Scenic and Unique}

A ribbon of highway rolls out under an endless skyway, over wide coastal bluffs beside miles of easy beaches. Elephant seals snooze on the ocean side, cows and zebras mingle on the mountain side. A castle full of treasure crowns an enchanted hill, a lighthouse waits for fog, a gas station is nowhere in view. The narrow road climbs abruptly into the mountains, curving around cliffs that drop hundreds of feet to the sea, dipping into redwood forest canyons, rambling through golden valleys.

Route 1 between San Luis Obispo and Monterey is known worldwide as a wonderful, wild ride. The few small towns between these storied cities have retained their own unique qualities. Visitors shop for antiques in Cayucos, wine in Harmony, art in Cambria. Gorda's got gas, to the great relief of many travellers over the years. Morro Bay is renowned for fresh seafood, and Californio cuisine is easy to find along the Byway. Old Spanish Missions and railroads attract history buffs. Hikers, mountain bikers and road bikers, surfers and kayakers have lots of room to play. Wildlife sanctuaries abound, and so does the wildlife.

\section{Preserve and Enhance}

The National Scenic Byways Program was established to recognize, preserve and enhance exceptional roads like ours throughout the US.

A National Scenic Byway offers at least one of these 'intrinsic qualities': natural, historic, cultural, scenic, recreational, or archaeological.

An All-American Road offers multiple intrinsic qualities, and is considered nationally significant because nothing like it exists anywhere else. An All-American Road is a "destination unto itself" that provides an exceptional travel experience.

The Federal Highway Administration directs the program for the US Dept of Transportation. Since 1991, FWHA has designated 121 National Scenic Byways and 31 All-American Roads in 46 states. Some $\$ 388$ million in grants has been disbursed, including more than $\$ 3$ million locally for land acquisition, Coastal Trail development, planning, community gateways, and the subject of this Plan: interpretation that engages, guides, and informs visitors about the Byway's many amenities.

\section{\& All-American Road}

\section{The America's Byways ${ }^{\circledR}$ Collection}

National Scenic Byways and All-American Roads are part of the America's Byways ${ }^{\circledast}$ collection, a marketing effort of the Byways Resource Center.

California has just seven Byways and three All-American Roads. The coast route between San Luis Obispo and Monterey is both a National Scenic Byway and an All-American Road, split into two adjoining Byways.

The Route 1, San Luis Obispo North Coast Byway spans 57 miles, from San Luis Obispo to the County line, and the Route 1, Big Sur Coast Byway winds another 72 miles into Monterey.

Numerous studies have shown Scenic Byway designation increases visitors to an area as much as $25 \%$, boosting the local economy and helping to protect the region's intrinsic qualities.

A new Byways Resource Center campaign promotes San Francisco and the Route 1 Byways. The multi-year plan includes multi-lingual media and multiple channels that will bring more international visitors to our Byway.
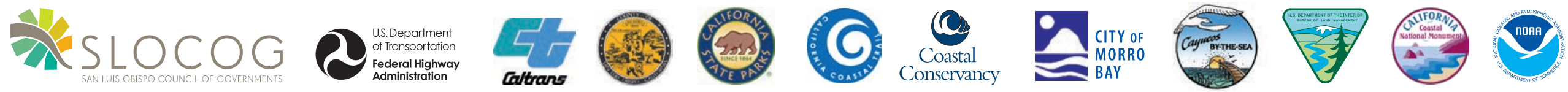


\section{SLO Coast Byway}

\section{SLO Coast Byway Interpretive Signage Plan: A Work in Progress}

\section{Contents}

Introduction

Panel List, Goals, Timeline.................3

Common Elements ..................... 4

Themes, Materials ..................... 5

Panel Locations Map .................... 6

Interpretive Panel Details ........... 7 - 25

BY.W1-MorroBay..........................7

BY.W2-Cayucos $\ldots \ldots \ldots \ldots \ldots \ldots \ldots \ldots \ldots$

BY.W3-Cambria.......................9

BY.W4-SanSimeon ...........................10

BY.W5-SLOcoast ....................... 11

BY.MB1-fishing ......................... 12

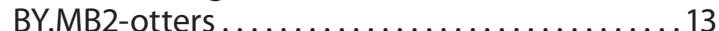

BY.MB3-morros.......................... 14

BY.MB4-whales..........................15

BY.CAY1-nearshore ..................... 16

BY.EB1-EsteroBluffs........................... 17

BY.HH1-HarmonyHeadlands ............... 18

BY.CCT1-trails.......................... 19

BY.PICO1-native ......................20

BY.PICO2-mombaby $\ldots \ldots \ldots \ldots \ldots \ldots \ldots .21$

BY.NA-highwayone ${ }^{*} \ldots \ldots \ldots \ldots \ldots \ldots \ldots \ldots .22$

BY.NA-lightstation* ${ }^{*} \ldots \ldots \ldots \ldots \ldots \ldots \ldots \ldots .23$

BY.NA-MPA* $\ldots \ldots \ldots \ldots \ldots \ldots \ldots \ldots \ldots . .24$

BY.NA-CCNM ${ }^{*} \ldots \ldots \ldots \ldots \ldots \ldots \ldots \ldots \ldots \ldots, 25$

Posts (Pedestals) . . . . . . . . . . . . . . . 26-28

Proofs Summary. ... . . . . . . . . . . . . . . 29-34

* NA = Not Assigned (location unknown)

Caltrans may take highwayone and lightstation panels. MPA and CCNM panels canceled.

\section{Interpretive Goals}

Goal 1: Welcome, orient, entertain, and inform visitors about local amenities, attractions, and travel options.

Goal 2: Encourage respectful behavior towards local assets, including wildlife, habitat, and historic treasures.

Goal 3: Collaborate with land managers, interpreters, local leaders and others to create an outstanding product.

\section{Panel List}

BY.W1 - BY.W5

BY.MB1 - BY.MB4

BY.EB1

BY.HH1

BY.CCT1

BY.PICO1 - BY.PICO2

BY.CAY1

BY.NA

Total Panels

\section{Timeline Tasks}

FINALIZE PANEL LOCATIONS AND PERMITS

FINAL PROOFS DUE

PERMITTING COMPLETE

PANELS PREPPED FOR PRINT

PANELS \& PEDESTALS ORDERED

PANELS \& PEDESTALS DELIVERED

INSTALLATION 


\section{Colors}

The Byways Resource Center created a color scheme to denote the various intrinsic qualities on Byway materials.

\section{General Program / Wayfinding}

Pantone $194 \cdot$ Process $110-1$ C0-M100-Y60-K40 • R65.5-60.4-B14.5

\section{Historic}

Pantone $7512 \bullet$ Process $41-1$

C30-M70-Y100-K10 • R58-G26.9-B14.3

\section{Cultural}

Pantone 2623 - Process 173-1

C70-M100-YO-K10 • R27.6-613-B36.7

\section{Natural}

Pantone 356 - Process 272-1

G100-M0-Y90-K20 • R0-G41.2-B21.4

\section{Archaeological}

Pantone $131 \cdot$ Process $23-1$

C0-M40-Y100-K10 • R84.7-G45-B10.8

\section{Recreationa}

Pantone $173 \cdot$ Process 57

C0-M80-Y100-K10 • R79.4-G21.2-B12.2

\section{Scenic}

Pantone $285 \bullet$ Process 214-1

C100-M40-Y0-K0 • R0-G40-B67.

\section{Logos}

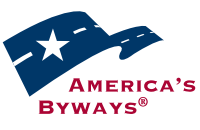

The America’s Byways ${ }^{\circledR}$ logo is featured prominently in the Sidebar on every panel.

Logos of partner agencies and organizations may appear on the Sidebar of relevant panels, all sized the same but with lead agencies' logos shown first or in the top row. Page 3 shows the logos of SLO Coast Byway partners.

The SLO Coast Byway logo will be attached to road signs carrying the California Scenic Route "poppy and mountain" logo. The new SLO Coast Byway logo was approved by the Board in October 2010.

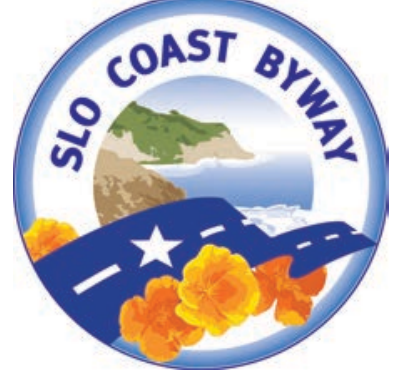

Tags

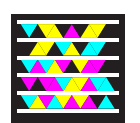

This Tag is a barcode developed by Microsoft. ${ }^{*}$ Also known as a QR code (quick response), the Tag works with any camera phone that has internet access and the free Tag software. Aim a smart phone at a Tag to get connected to the website encoded in the Tag.

The Tag on the Sidebar takes visitors to SLO Coast Byway page on Byways.org, where visitors can get updated information and maps, customized brochures, and much more than can be shown on a panel.

A second Tag common to all panels takes visitors to a map of California. Additional Tags have been added to the Sidebar on all panels.

${ }^{*}$ Microsoft will discontinue support for MS Tags in August 2015. It is unclear at this time if the funding can be found to arrange support for the Tags by ScanLife, which has been chosen by Microsoft to continue support for the Tags. Probably all Tags will be removed from the panels, and not replaced with the more common type of $Q R$ code, which must be printed larger.

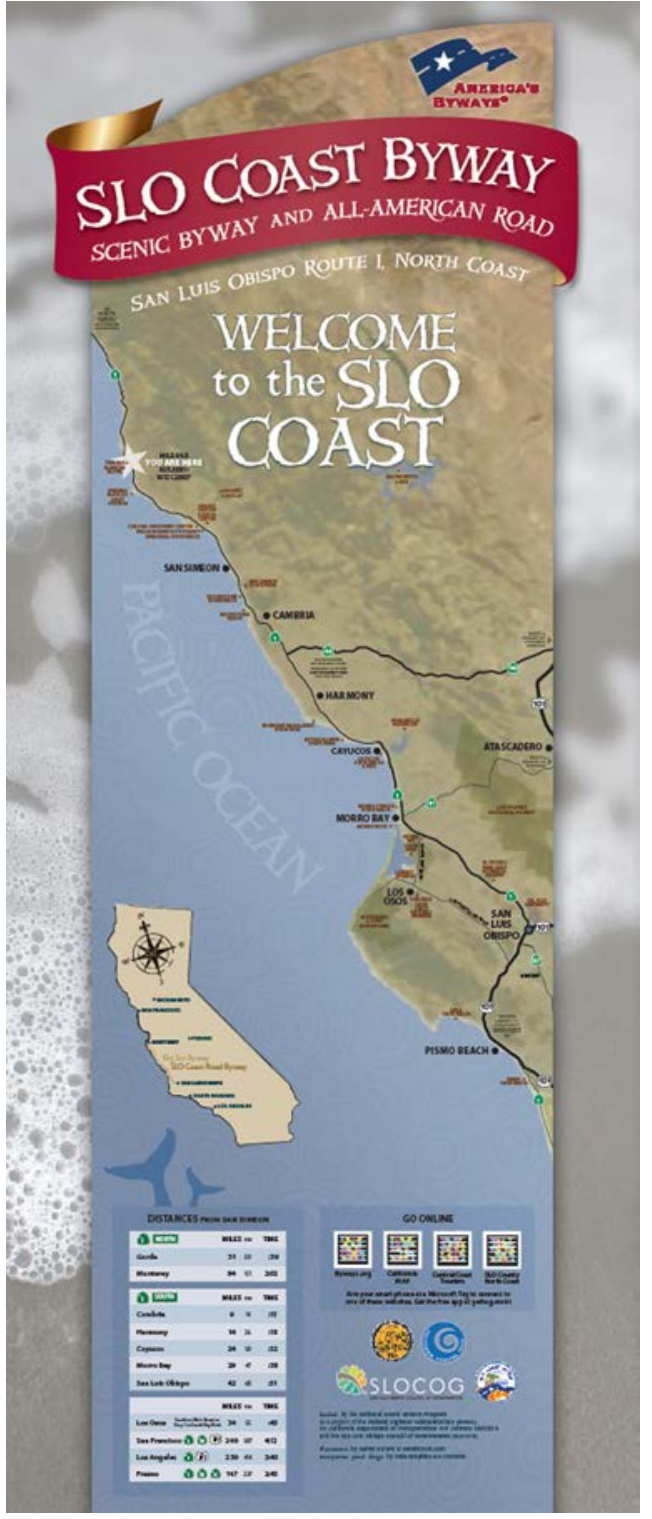




\section{Interpretive Themes}

"SLO Coast Road" describes the Route 1, San Luis Obispo North Coast Byway succinctly and memorably. It invites people to take it easy on the road, to enjoy the drive.

Themes are in development for individual panels. Topics are analyzed for the best way to show and tell the story. The topic of Morros becomes the story of Seven Sisters who moved to Morro Bay from Palm Springs at the speed of a growing fingernail. (It took 25 million years.) Our goal is to entertain while we educate. Topics (not themes) include:

(6) Natural: Sea Otters; Sea Mammals; Near-Shore Habitat; Cetaceans; Marine Protected Areas*; California Coastal National Monument*

(3) Historical: Highway 1*; Indigenous People; Piedras Blancas Light Station*

(1) Cultural: Fishing Industry

(1) Scenic: The Morros

(8) Wayfinding: Welcome Morro Bay, Cayucos, Cambria, San Simeon, SLO Coast; California Coastal Trail; Estero Bluffs; Harmony Headlands

*MPA, CCNM panels have been removed. Highway 1, Light Station panels to Caltran?

\section{Panel and Pedestal Materials}

The panels will be high-pressure laminate (HPL), a durable plastic with a 10-year guarantee against fading. Panel surfaces are treated for easy removal of graffiti with glass cleaner or WD40, though panels can be damaged with knives and bullets. HPL is the most environmental choice because it does not outgas toxins over its lifetime. Some HPL panels have been in place over 20 years.

Panel dimensions are 48" wide x 30 " tall $\times .5$ " thick.

Pedestals will have extra-long posts set in concrete to prevent removal. Panel height and display angle will follow State Park public access guidelines, which exceed federal and state ADA guidelines.

\section{Changes and Versions of the Plan}

This is the second update of Draft 8 of the Interpretive Signage Plan. Subsequent drafts will come out when enough changes have collected, or a meeting of our Advisory Group or SLOCOG Board is scheduled to review the Plan. Note the dates on the document's cover and at the bottom of every page.

\section{Your Comments are Welcome}

This Interpretive Signage Plan has been developed with our Partners to showcase the history and great natural beauty of our Byway.

We've visited all the sites and connected with dozens of people to develop this series of interpretive panels: Park Rangers and Interpreters, Land Managers, Historians and Archeologists, Biologists, Researchers, Scientists, Librarians, Museum and Visitor Center Managers, Environmental Organizations, Designers, Artists, Photographers, Landscape Architects, and Transportation Planners. Many thanks to all who have been so accommodating and helpful throughout the process. 

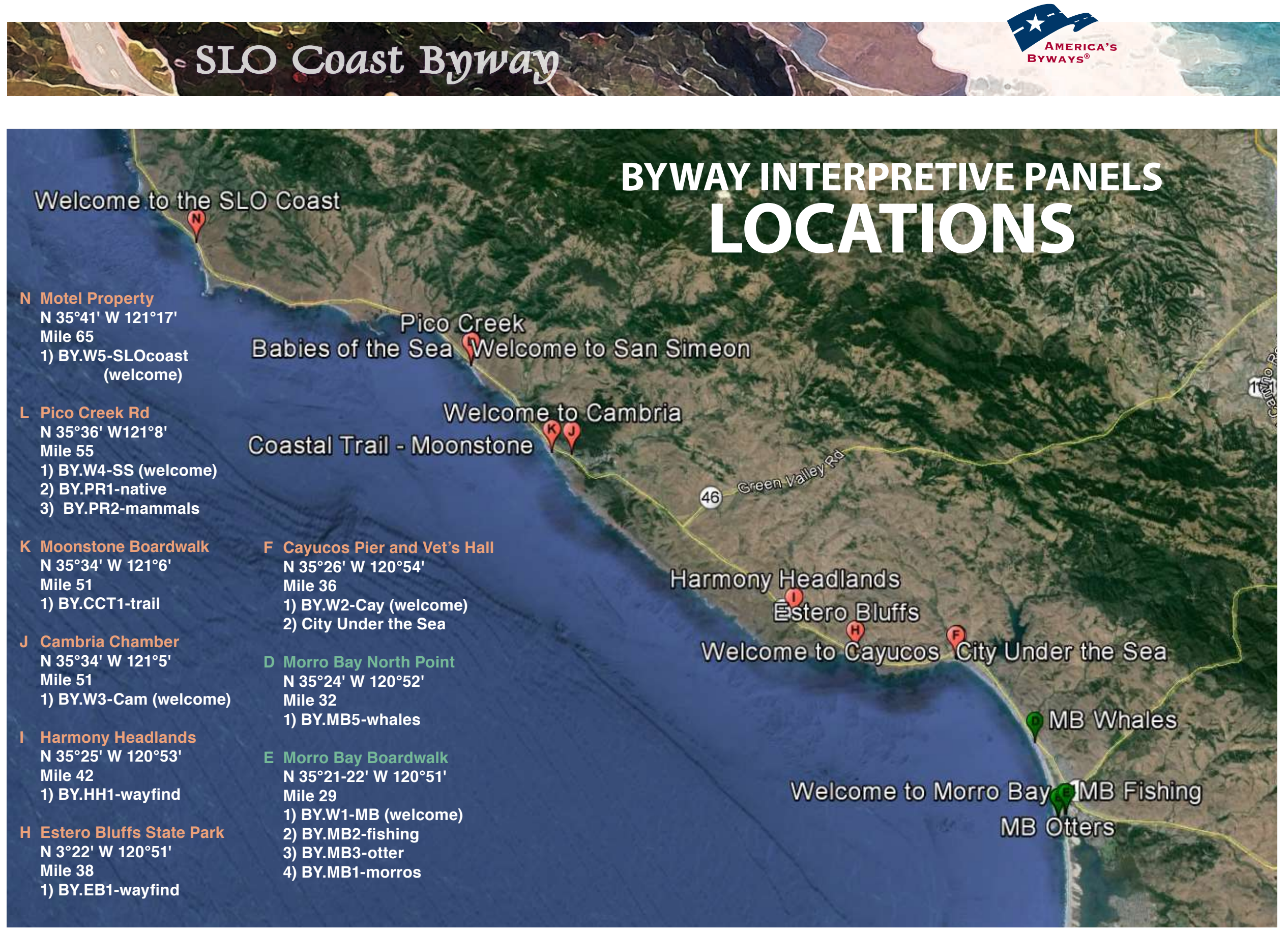


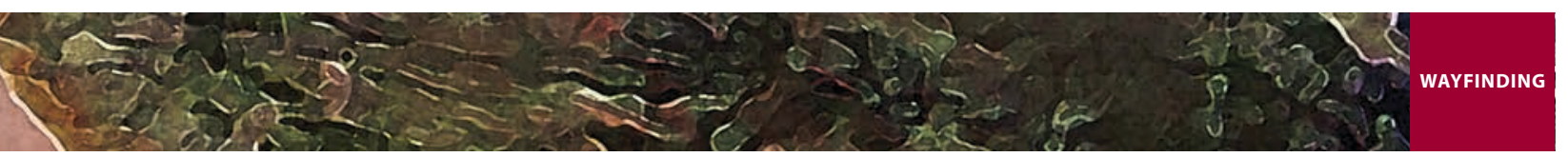

W1

TOPIC

DESCRIPTION

\section{Welcome to Morro Bay Orientation/Wayfinding}

This is 1 of 5 Welcome panels, and 1 of 4 on the Morro Bay HarborWalk, and 1 of 5 panels in Morro Bay.

CONTACTS Joe Woods jwoods@morro-bay.ca.us 772-6278 City of Morro Bay Director Recreation \& Parks

Geiska Velasquez gvelasquez@slocog.org 788-2104 SLOCOG, Regional Planner

Rich Murphy rmurphy@slocog.org 781-5754 SLOCOG, Programming Director
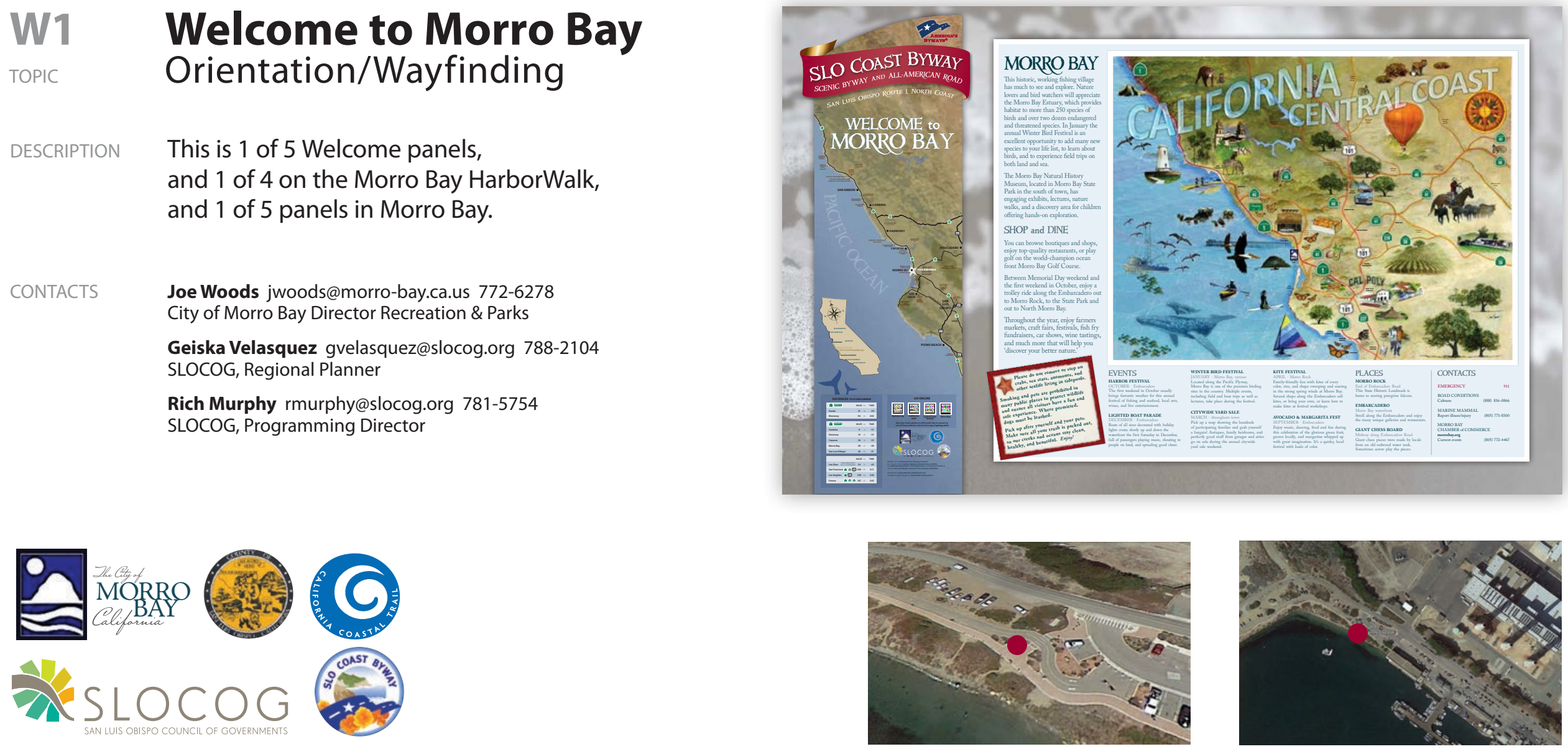

\begin{tabular}{|c|c|c|c|}
\hline \multirow{2}{*}{$\begin{array}{c}\text { M I L E } \\
29\end{array}$} & NAME WELCOME TO MORRO BAY! & FILE NAME BY.W1-MorroBay & CELL YES \\
\hline & LOCATION MORRO BAY TROLLEY STOP @ RESTROOM not in front of view & PARTNER CITY OF MORRO BAY & PERMIT YES \\
\hline $\begin{array}{l}N 35^{\circ} 21^{\prime} 1^{\prime \prime} \\
\text { W } 120^{\circ} 51^{\prime} 39^{\prime \prime}\end{array}$ & LANDOWNER CITY OF MORRO BAY & MANAGER JOE WOOD & BASE SAND \\
\hline
\end{tabular}




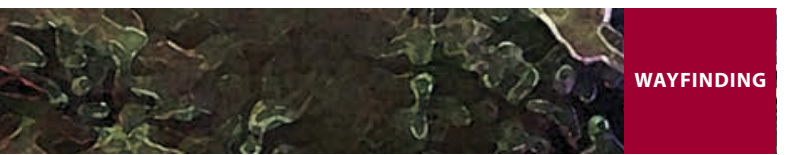

W2

TOPIC

DESCRIPTION

CONTACTS

\section{Welcome to Cayucos Orientation/Wayfinding}

This is 2 of 5 Welcome panels, and 1 of 2 panels in Cayucos.

Mike Hargett 235-5845

Visitor Alliance of Cayucos

John Carsel jmaytoe@yahoo.com 785-0961

Geiska Velasquez gvelasquez@slocog.org 788-2104 SLOCOG, Regional Planner

Rich Murphy rmurphy@slocog.org 781-5754

SLOCOG, Programming Director
Visitor Alliance of Cayucos
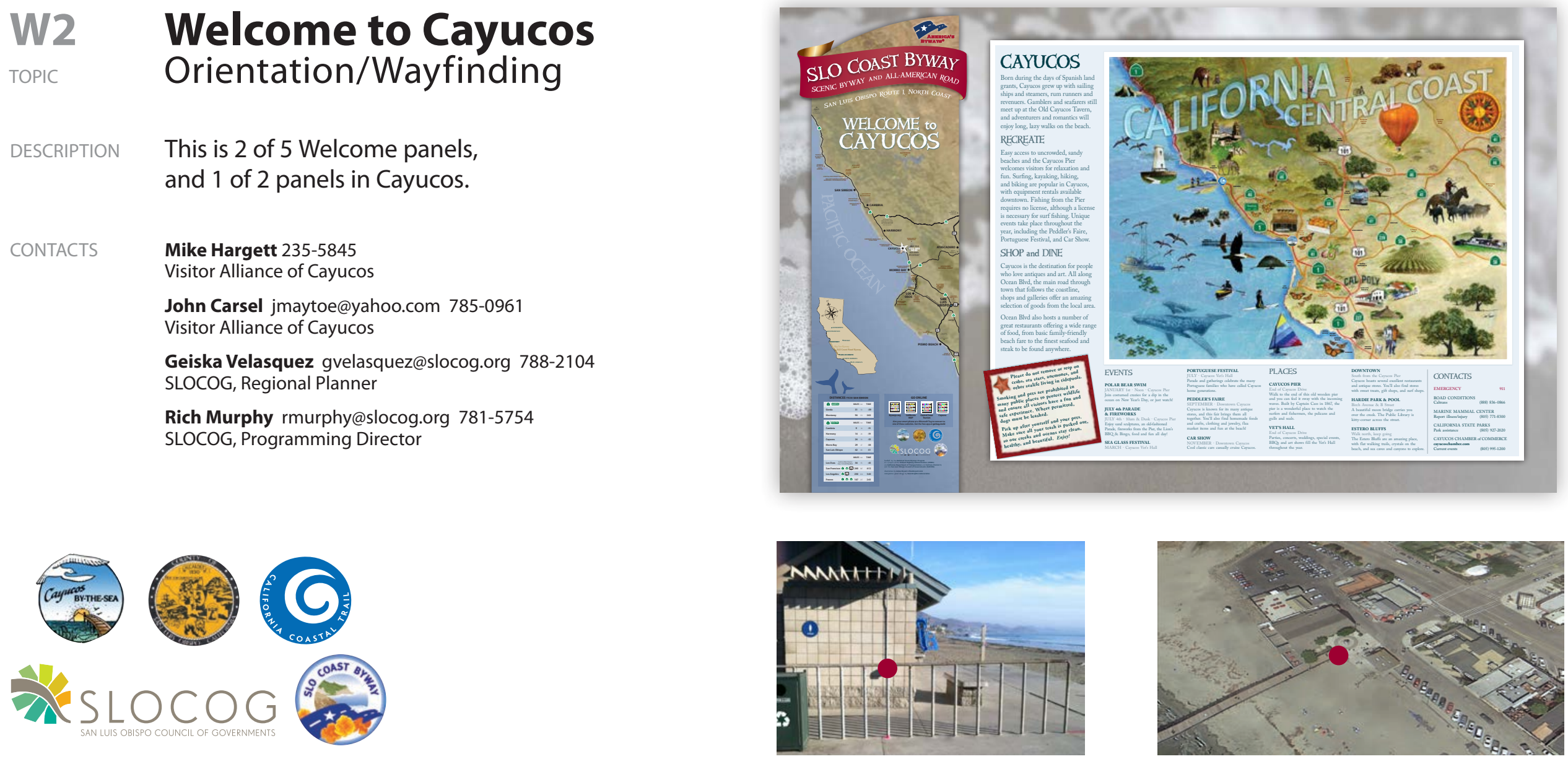

\begin{tabular}{|c|c|c|c|}
\hline \multirow{3}{*}{$\begin{array}{l}\text { M I L E } \\
36 \\
\text { N } 35^{\circ} 26^{\prime} 57^{\prime \prime}\end{array}$} & NAME WELCOME TO CAYUCOS & FILE NAME BY.W2-Cayucos & CELL YES \\
\hline & LOCATION CAYUCOS PIER, in front of rail, in front of restroom & PARTNERS CAYUCOS, COUNTY OF SAN LUIS OBISPO & PERMIT YES \\
\hline & LANDOWNER COUNTY of SAN LUIS OBISPO & MANAGERS MIKE HARGETT, JOHN CARSEL & BASE CONCRETE \\
\hline
\end{tabular}




\section{PANELS}

\section{W3}

TOPIC

DESCRIPTION

This is 3 of 5 Welcome panels, located on the wall of the building next door to the Cambria Chamber of Commerce, and 1 of 2 panels in Cambria (with the California Coastal Trail panel).

CONTACTS Mel McColloch mmccolloch@yahoo.com 459-0220 Cambria Chamber of Commerce, President

Geiska Velasquez gvelasquez@slocog.org 788-2104 SLOCOG, Regional Planner

Rich Murphy rmurphy@slocog.org 781-5754 SLOCOG, Programming Director
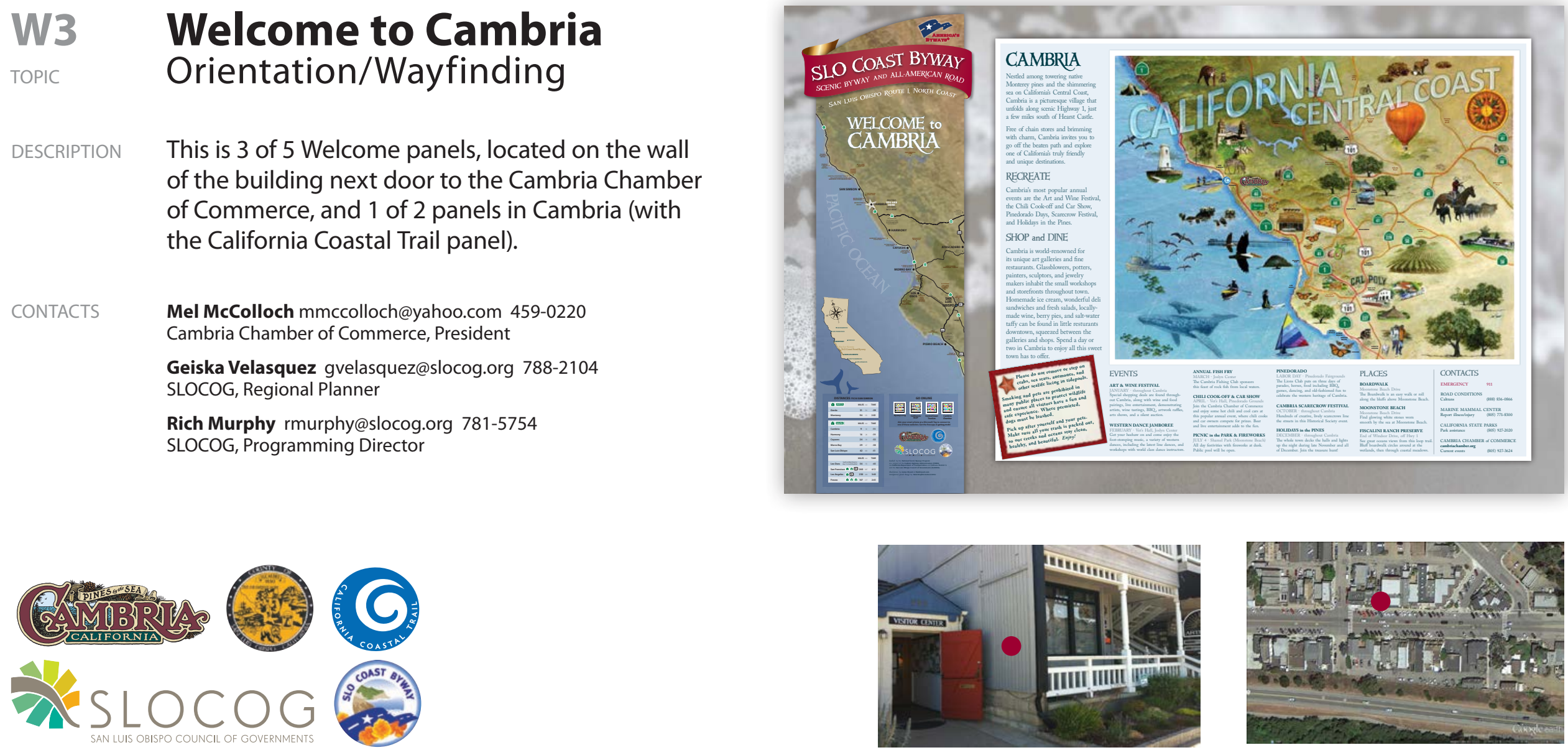

\begin{tabular}{|c|c|c|c|}
\hline \multirow{2}{*}{$\begin{array}{l}\text { M I L E } \\
50.5\end{array}$} & NAME WELCOME TO CAMBRIA & FILE NAME BY.W3-Cambria & CELL MAYBE \\
\hline & LOCATION CAMBRIA CHAMBER OF COMMERCE OFFICE & PARTNERS CAMBRIA, COUNTY OF SAN LUIS OBISPO & PERMIT YES \\
\hline $\begin{array}{l}N 35^{\circ} 34^{\prime \prime \prime} \\
\text { W } 121^{\circ} 5^{\prime} 59^{\prime \prime}\end{array}$ & LANDOWNER PRIVATE & MANAGER MEL MCCULLOCH & BASE WOODWALL \\
\hline
\end{tabular}


W4

TOPIC

DESCRIPTION

CONTACTS

\section{Welcome to San Simeon Orientation/Wayfinding}

This is 4 of 5 Welcome panels, and 1 of 3 at the ocean end of Pico Creek Road.

Renee Lundy rlundy@sansimeoncsd.org 927-4778 Charles Grace, Michele Roest

San Simeon CSD

Geiska Velasquez gvelasquez@slocog.org 788-2104 SLOCOG, Regional Planner

Rich Murphy rmurphy@slocog.org 781-5754

SLOCOG, Programming Director
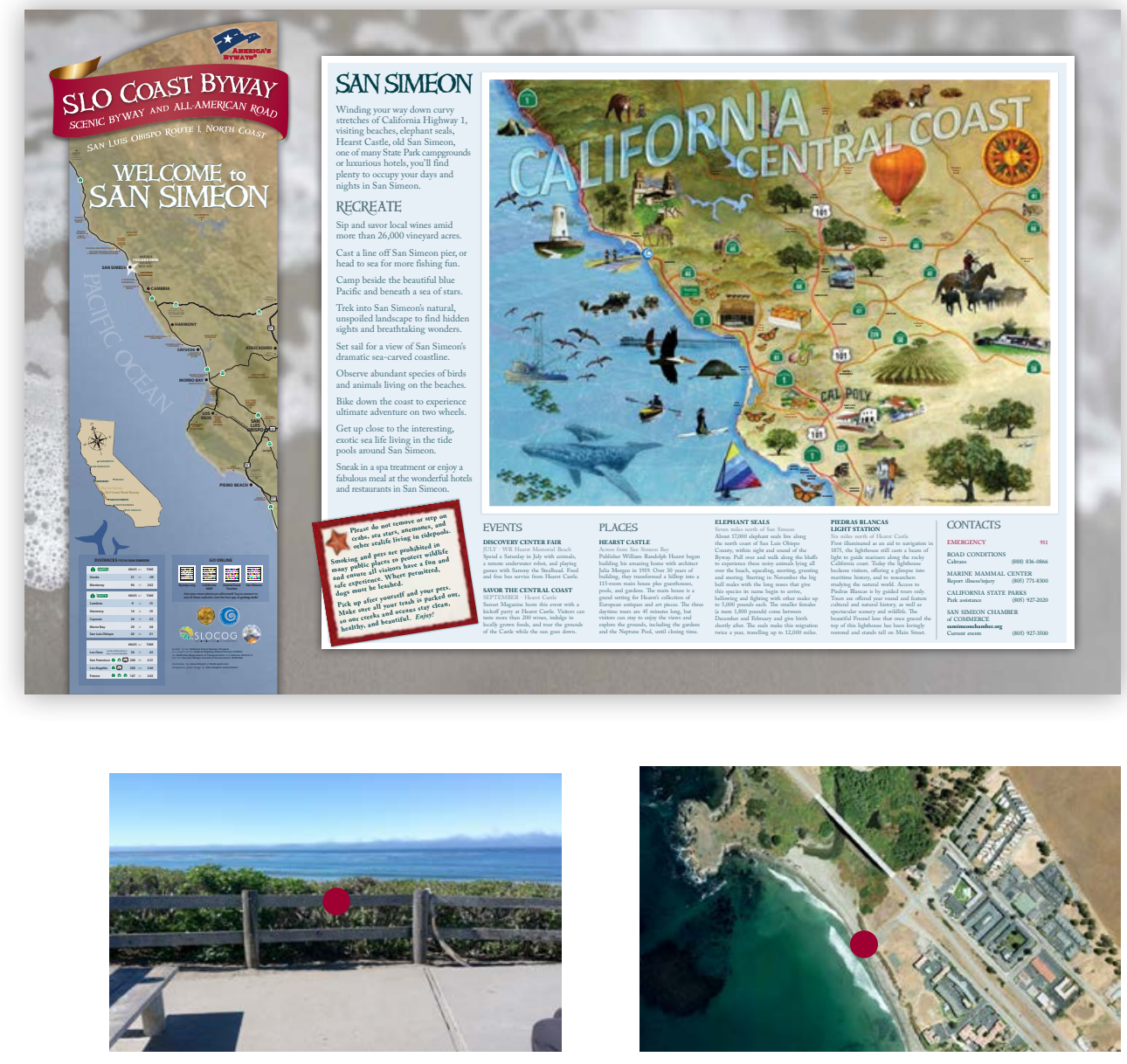

\begin{tabular}{|c|c|c|c|}
\hline \multirow{3}{*}{ 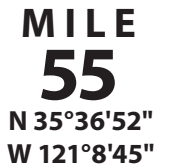 } & NAME WELCOME TO SAN SIMEON & FILE NAME BY.W4-SanSimeon & CELL YES \\
\hline & LOCATION PICO CREEK RD, SAN SIMEON & PARTNERS SAN SIMEON CSD, COUNTY OF SAN LUIS OBISPO & PERMIT NO \\
\hline & LANDOWNER SAN SIMEON COMMUNITY SERVICE DISTRICT & MANAGER RENEE LUNDY & BASE DIRT \\
\hline
\end{tabular}




\section{W5}

TOPIC

DESCRIPTION

CONTACTS

\section{Welcome to the SLO Coast Orientation/Wayfinding}

This is 5 of 5 Welcome panels. This panel will be located at the Piedras Blancas Motel.

Cara O’Brien cara@hearstcastle.com 927-2125

CA State Parks, Interpreter II

Doug Barker dbarker@hearstcastle.com 927-6291 CA State Parks, Staff Parks \& Recreation Specialist

Geiska Velasquez gvelasquez@slocog.org 788-2104 SLOCOG, Regional Planner

Rich Murphy rmurphy@slocog.org 781-5754 SLOCOG, Programming Director
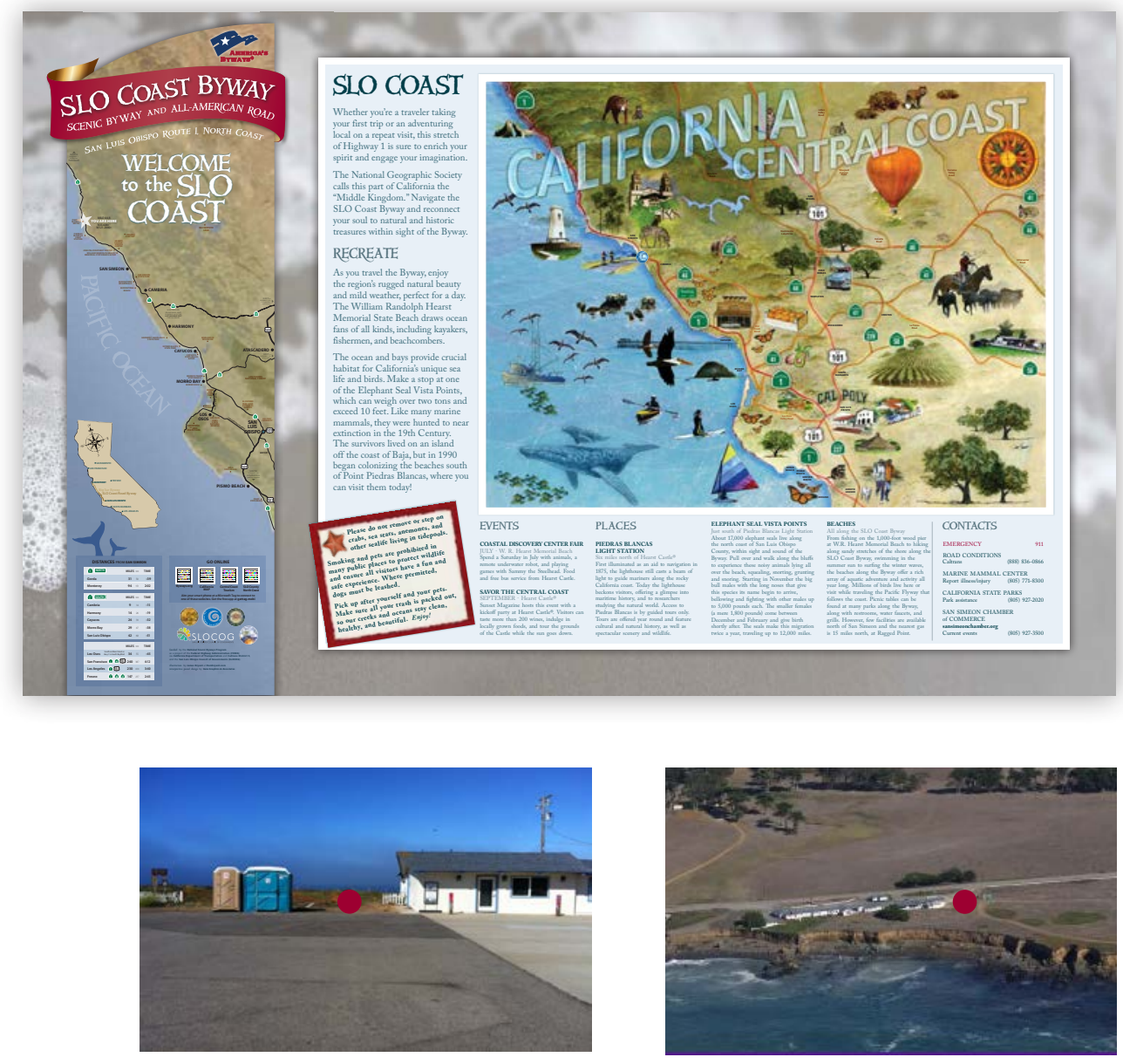

\begin{tabular}{|c|c|c|c|}
\hline \multirow{3}{*}{$\begin{array}{c}\text { M I LE E } \\
65 \\
\text { N 3541'15" } \\
\text { W121 }\end{array}$} & NAME WELCOME TO THE SLO COAST BYWAY & FILE NAME BY.W5-SLOcoast & CELL MAYBE \\
\hline & LOCATION PIEDRAS BLANCAS MOTEL SOUTH SIDE & PARTNER CA STATE PARKS & PERMIT YES \\
\hline & LANDOWNER CA STATE PARKS & MANAGER CARA O'BRIEN & BASE DIRT \\
\hline
\end{tabular}




\section{MB1}

TOPIC

DESCRIPTION

This is 2 of 4 panels for the Morro Bay HarborWalk, and 2 of 5 panels in Morro Bay.

This panel will be redesigned to focus on the history of fishing in Morro Bay.

CONTACTS

Joe Woods jwoods@morro-bay.ca.us 772-6278 City of Morro Bay Director Recreation \& Parks

Geiska Velasquez gvelasquez@slocog.org 788-2104 SLOCOG, Regional Planner

Rich Murphy rmurphy@slocog.org 781-5754

SLOCOG, Programming Director
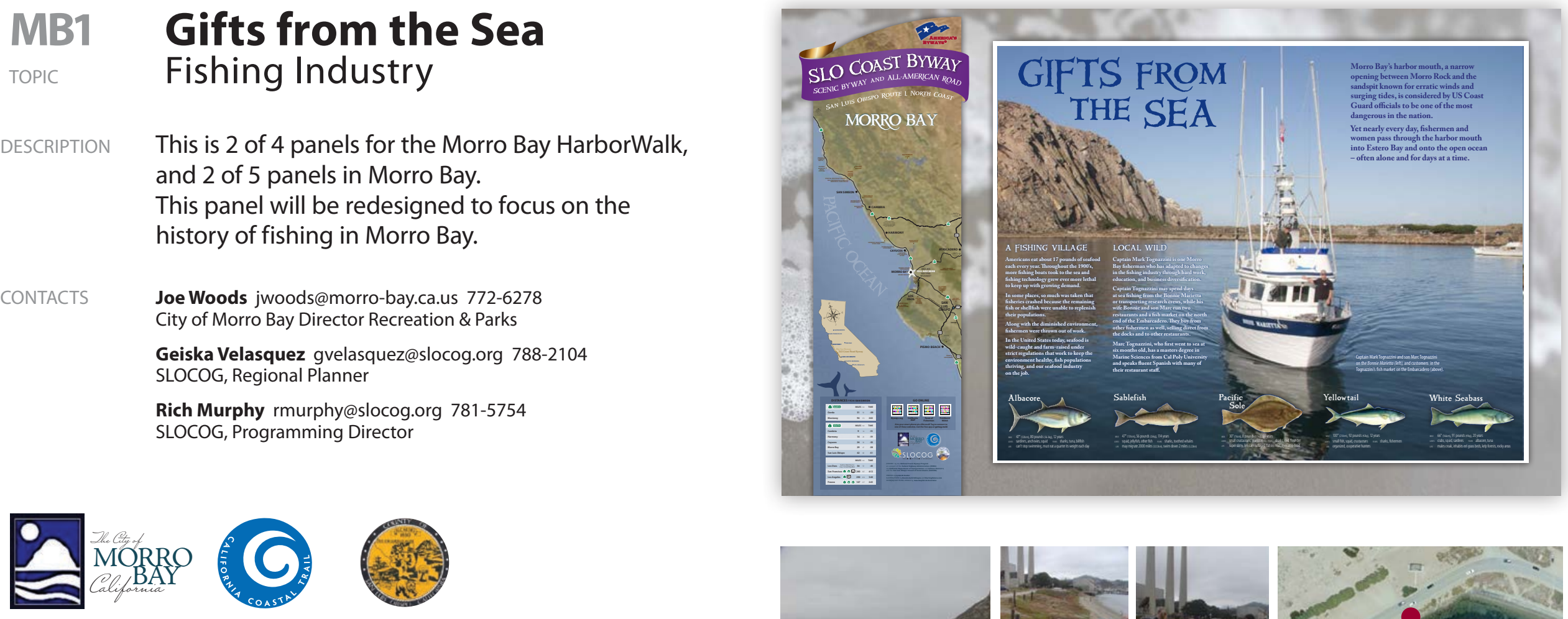

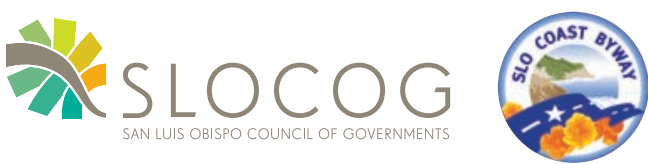
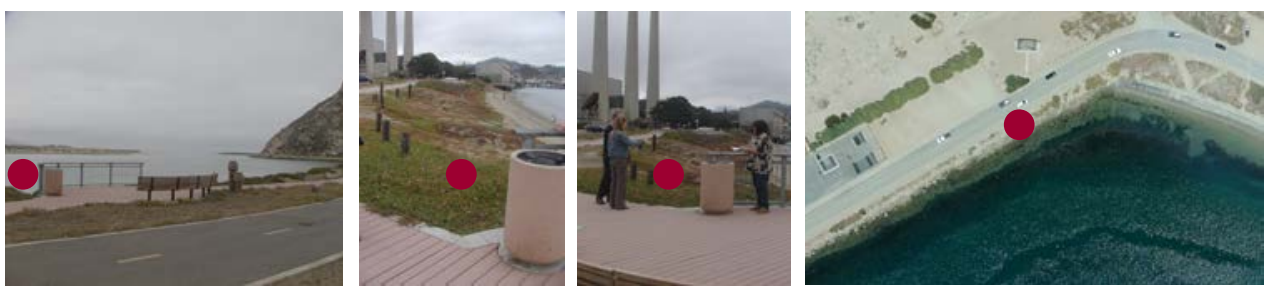

Panel placed in Coleman Park on the left of in the harbor.

\begin{tabular}{|c|c|c|c|}
\hline \multirow{3}{*}{$\begin{array}{c}\text { M I L E } \\
29 \\
\text { N 35०21'55" } \\
\text { w } 120^{\circ} 51^{\prime} 13^{\prime \prime}\end{array}$} & NAME GIFTS FROM THE SEA & FILE NAME BY.MB1-fishing & CELL YES \\
\hline & LOCATION MORRO BAY HARBORWALK - near fishermen's memorial & PARTNER CITY OF MORRO BAY & PERMIT YES \\
\hline & LANDOWNER CITY OF MORRO BAY & MANAGER JOE WOODS & BASE SAND \\
\hline
\end{tabular}


MB2 Endearing \& Endangered

TOPIC

DESCRIPTION

This is 3 of 4 panels on the Morro Bay HarborWalk, and 3 of 5 panels in Morro Bay.

CONTACTS

Joe Woods jwoods@morro-bay.ca.us 772-6278 City of Morro Bay Director Recreation \& Parks

Geiska Velasquez gvelasquez@slocog.org 788-2104 SLOCOG, Regional Planner

Rich Murphy rmurphy@slocog.org 781-5754 SLOCOG, Programming Director

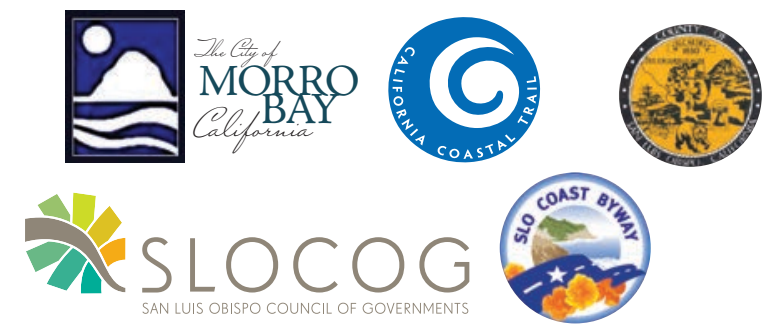

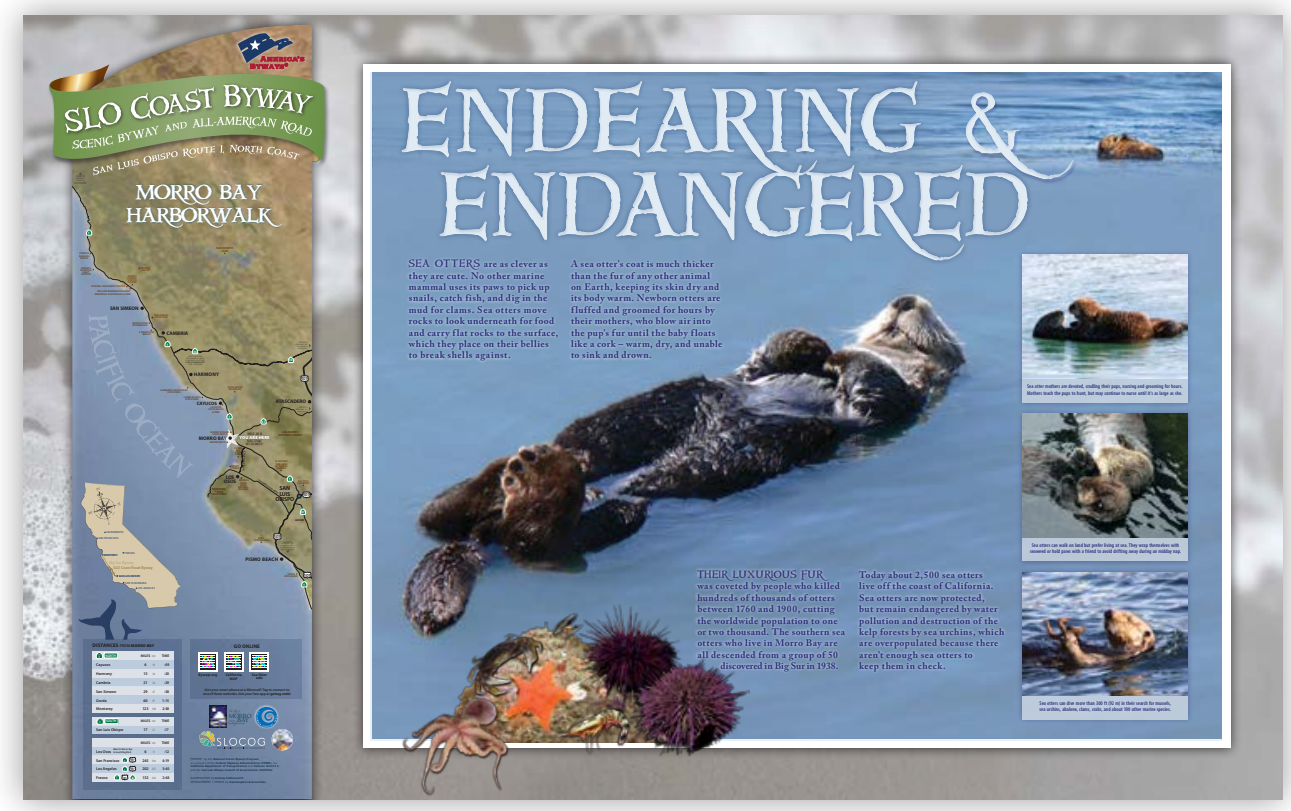
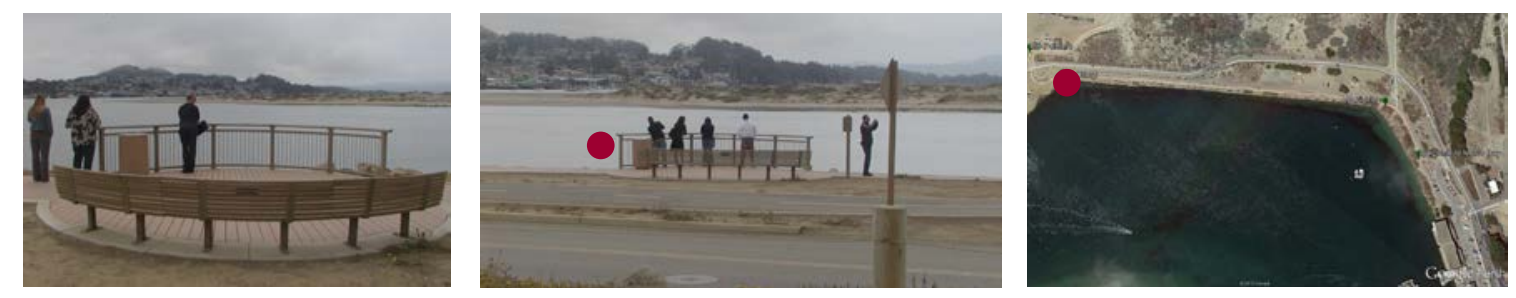

Panel placed in Coleman Park, at third bulbout.

Panel placed in Coleman Park, at third but.
By trash can or existing panel to the right.

\begin{tabular}{|c|c|c|c|}
\hline \multirow{2}{*}{$\begin{array}{c}\text { M I LE } \\
29\end{array}$} & NAME ENDEARING \& ENDANGERED & FILE NAME BY.MB2-otters & CELL YES \\
\hline & LOCATION MORRO BAY HARBORWALK - third bulbout & PARTNER CITY of MORRO BAY & PERMIT YES \\
\hline $\begin{array}{l}\text { N } 35^{\circ} 25^{\prime \prime} \\
\text { W } 120^{\circ} 10^{\prime \prime}\end{array}$ & LANDOWNER CITY of MORRO BAY & MANAGER JOE WOODS & BASE SAND \\
\hline
\end{tabular}




\section{MB3}

TOPIC

DESCRIPTION

CONTACTS

\section{Seven Sisters Move to MB The Morros and Morro Rock}

This is 4 of 4 panels along Morro Bay's Boardwalk, and 4 of 5 panels in Morro Bay.

Joe Woods jwoods@morro-bay.ca.us 772-6278 City of Morro Bay Director Recreation \& Parks

Geiska Velasquez gvelasquez@slocog.org 788-2104 SLOCOG, Regional Planner

Rich Murphy rmurphy@slocog.org 781-5754 SLOCOG, Programming Director
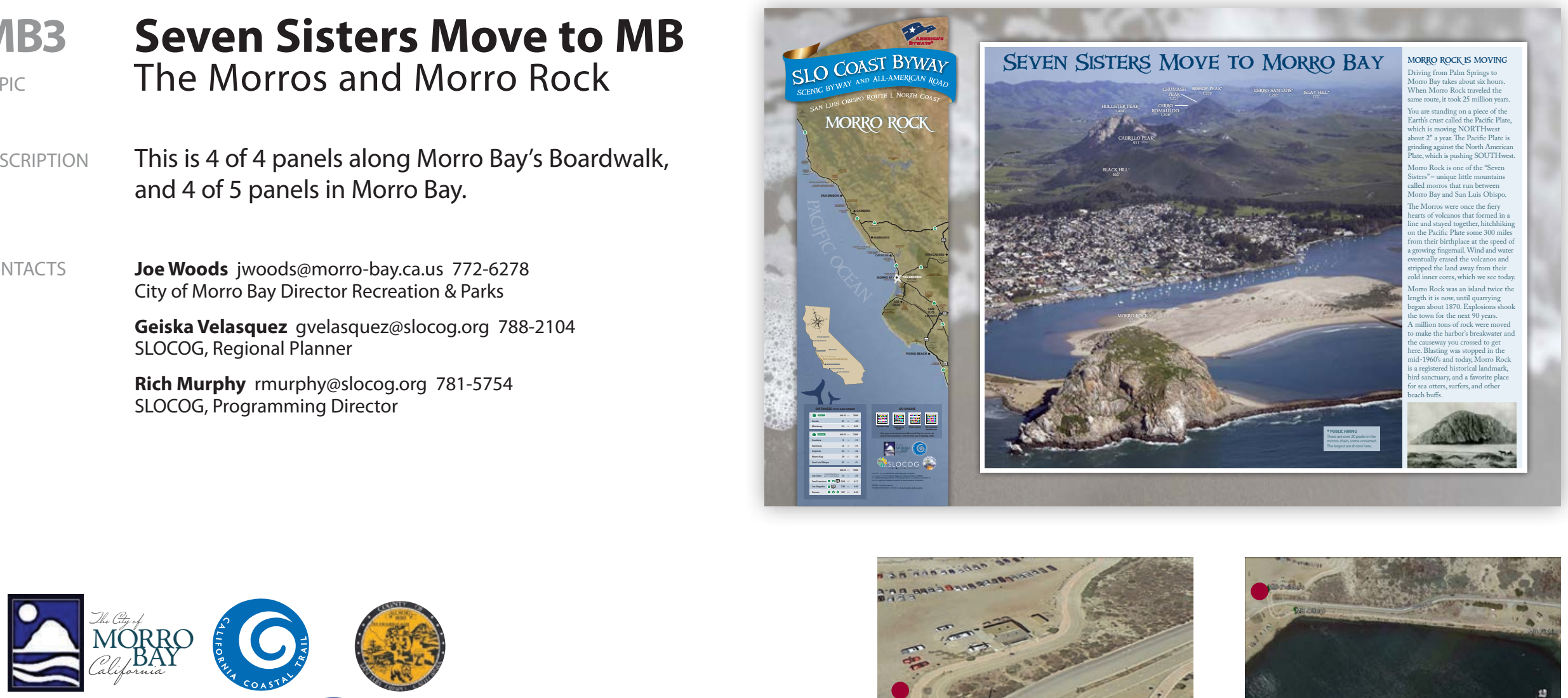

MORRO
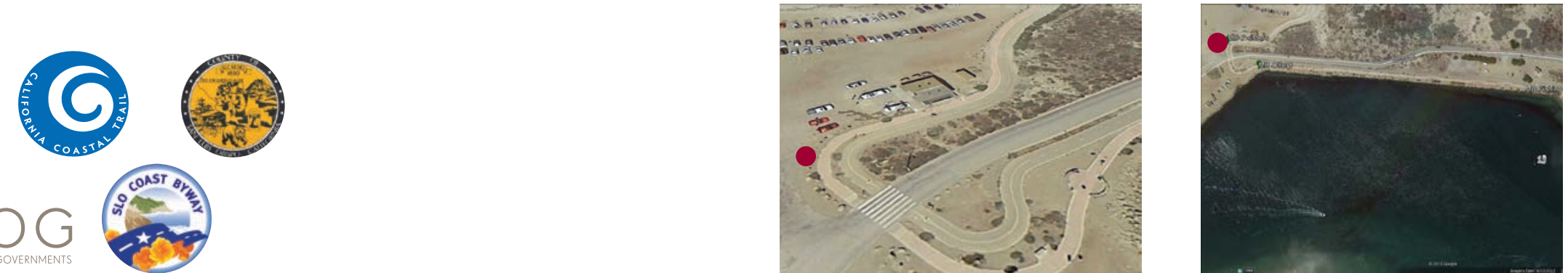

\begin{tabular}{|c|c|c|c|}
\hline \multirow{2}{*}{$\begin{array}{c}\text { M I LE } \\
29\end{array}$} & NAME SEVEN SISTERS MOVE TO MORRO BAY & FILE NAME BY.MB3-morros & CELL YES \\
\hline & LOCATION MORRO BAY - Boardwalk, north of Coleman Dr, near restroom & PARTNER CITY of MORRO BAY & PERMIT YES \\
\hline $\begin{aligned} & N 35^{\circ} 22^{\prime \prime \prime} \\
& W 120^{\circ} 51^{\prime} 17^{\prime \prime}\end{aligned}$ & LANDOWNER CITY of MORRO BAY & MANAGER JOE WOODS & BASE DIRT \\
\hline
\end{tabular}




\section{MB4}

TOPIC

DESCRIPTION

CONTACTS

\section{Watch for Whales! Cetaceans}

This is 1 of 1 panel at North Point in Morro Bay, and 5 of 5 panels in Morro Bay.

Joe Woods jwoods@morro-bay.ca.us 772-6278 City of Morro Bay Director Recreation \& Parks

Geiska Velasquez gvelasquez@slocog.org 788-2104 SLOCOG, Regional Planner

Rich Murphy rmurphy@slocog.org 781-5754 SLOCOG, Programming Director
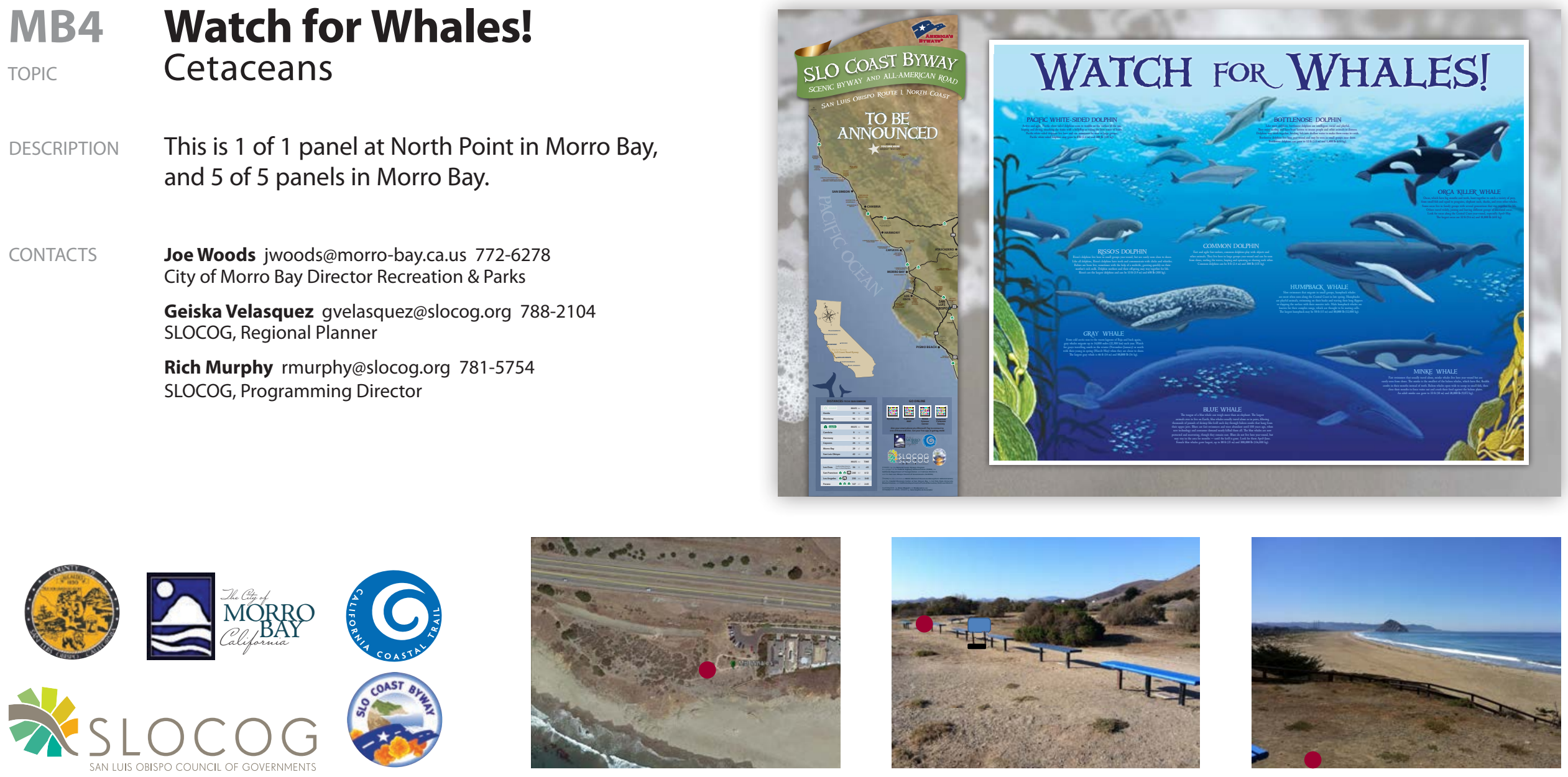

\begin{tabular}{|c|c|c|c|}
\hline \multirow{2}{*}{$\begin{array}{c}\text { M I LE } \\
32\end{array}$} & NAME WATCH FOR WHALES! & FILE NAME BY.MB4-whales & CELL YES \\
\hline & LOCATION MORRO BAY - North Point & PARTNER CITY of MORRO BAY & PERMIT YES \\
\hline W $121^{\circ} 52^{\prime} 7^{\prime \prime}$ & LANDOWNER CITY of MORRO BAY & MANAGER JOE WOODS & BASE SAND \\
\hline
\end{tabular}




\section{CAY1}

TOPIC

DESCRIPTION

CONTACTS Mike Hargett 235-5845

Visitor Alliance of Cayucos

John Carsel jmaytoe@yahoo.com 785-0961

Visitor Alliance of Cayucos

Geiska Velasquez gvelasquez@slocog.org 788-2104 SLOCOG, Regional Planner

Rich Murphy rmurphy@slocog.org 781-5754

SLOCOG, Programming Director
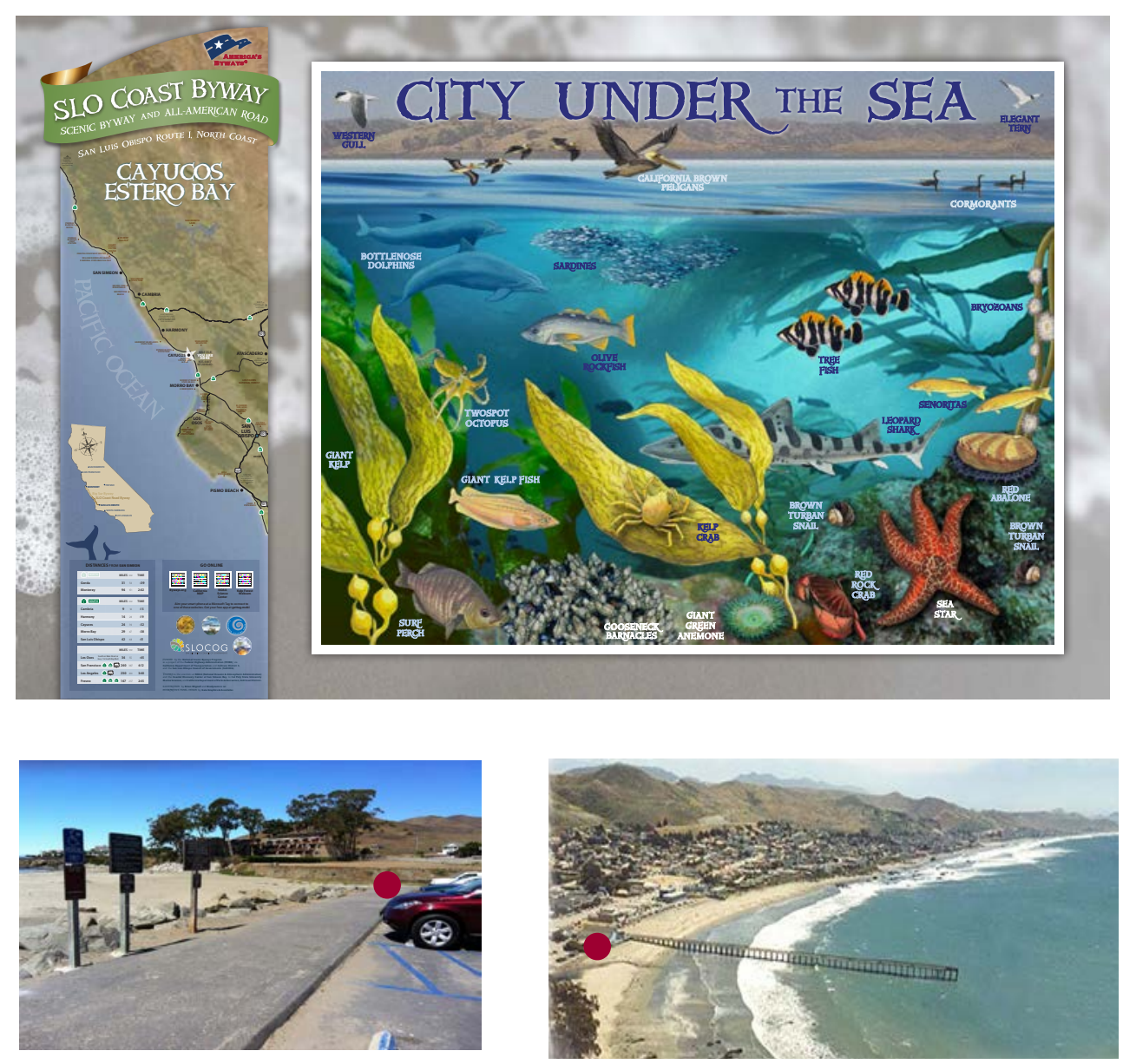

\begin{tabular}{|c|c|c|c|}
\hline \multirow{2}{*}{$\begin{array}{c}\text { M I LE } \\
36\end{array}$} & NAME CITY UNDER THE SEA & FILE NAME BY.CAY1-nearshore & CELL YES \\
\hline & LOCATION CAYUCOS, north of the Vet's Hall & PARTNER VISITOR ALLIANCE of CAYUCOS & PERMIT YES \\
\hline $\begin{array}{l}\text { N } 35^{2} 26^{\circ} 56^{\prime \prime} \\
\text { W } 120^{\circ} 54^{\prime} 23^{\prime \prime}\end{array}$ & LANDOWNER COUNTY of SAN LUIS OBISPO & MANAGERS JOHN CARSEL, MIKE HARGETT & BASE ASPHALT \\
\hline
\end{tabular}




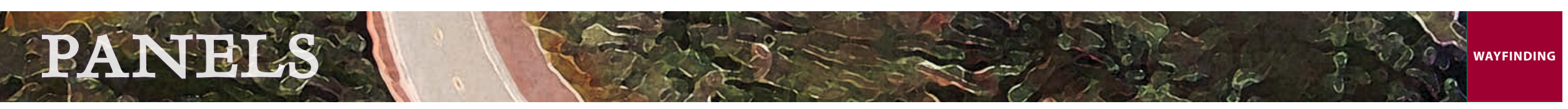

\section{EB1 Estero Bluffs State Park \\ TOPIC Wayfinding}

DESCRIPTION This is 1 of 1 panels at Estero Bluffs State Park.

CONTACTS Cara O’Brien cara@hearstcastle.com 927-2125 CA State Parks, Interpreter II

Geiska Velasquez gvelasquez@slocog.org 788-2104 SLOCOG, Regional Planner

Rich Murphy rmurphy@slocog.org 781-5754 SLOCOG, Programming Director
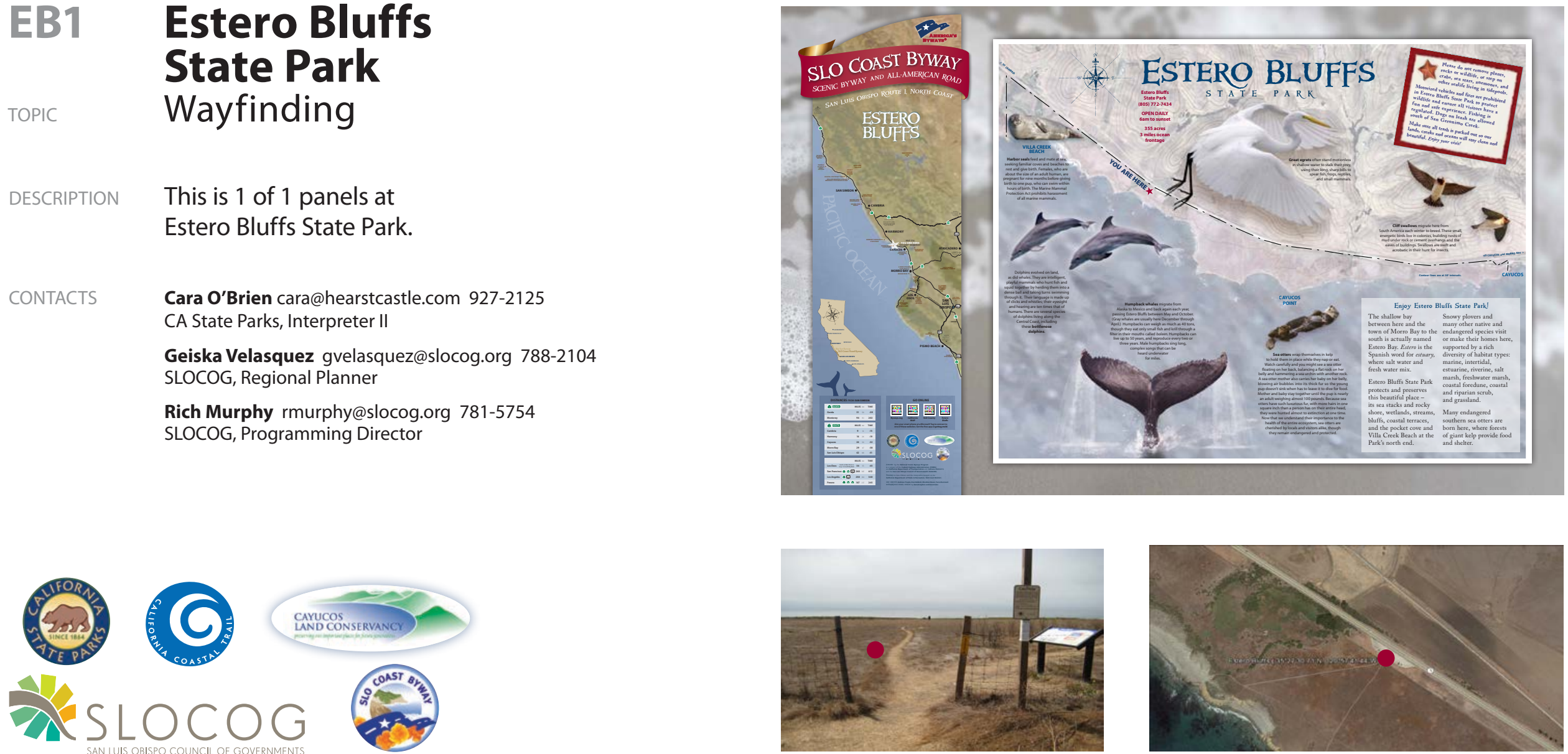

\begin{tabular}{|c|c|c|c|}
\hline \multirow{3}{*}{ 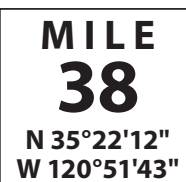 } & NAME ESTERO BLUFFS STATE PARK & FILE NAME BY.EB1-EsteroBluffs & CELL YES \\
\hline & LOCATION ESTERO BLUFFS STATE PARK - along trail & PARTNERS CA STATE PARKS & PERMIT YES \\
\hline & LANDOWNER CA STATE PARKS & MANAGERS CARA O'BRIEN & BASE DIRT \\
\hline
\end{tabular}




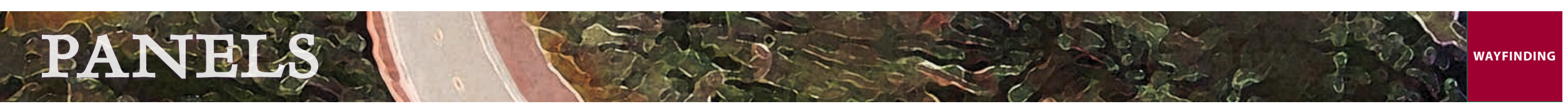

\section{HH1 Harmony Headlands State Park}

TоP $\quad$ Wayfinding

DESCRIPTION This is 1 of 1 panels at

Harmony Headlands State Park.

CONTACTS Cara O'Brien cara@hearstcastle.com 927-2125

CA State Parks, Interpreter II

Geiska Velasquez gvelasquez@slocog.org 788-2104 SLOCOG, Regional Planner

Rich Murphy rmurphy@slocog.org 781-5754

SLOCOG, Programming Director
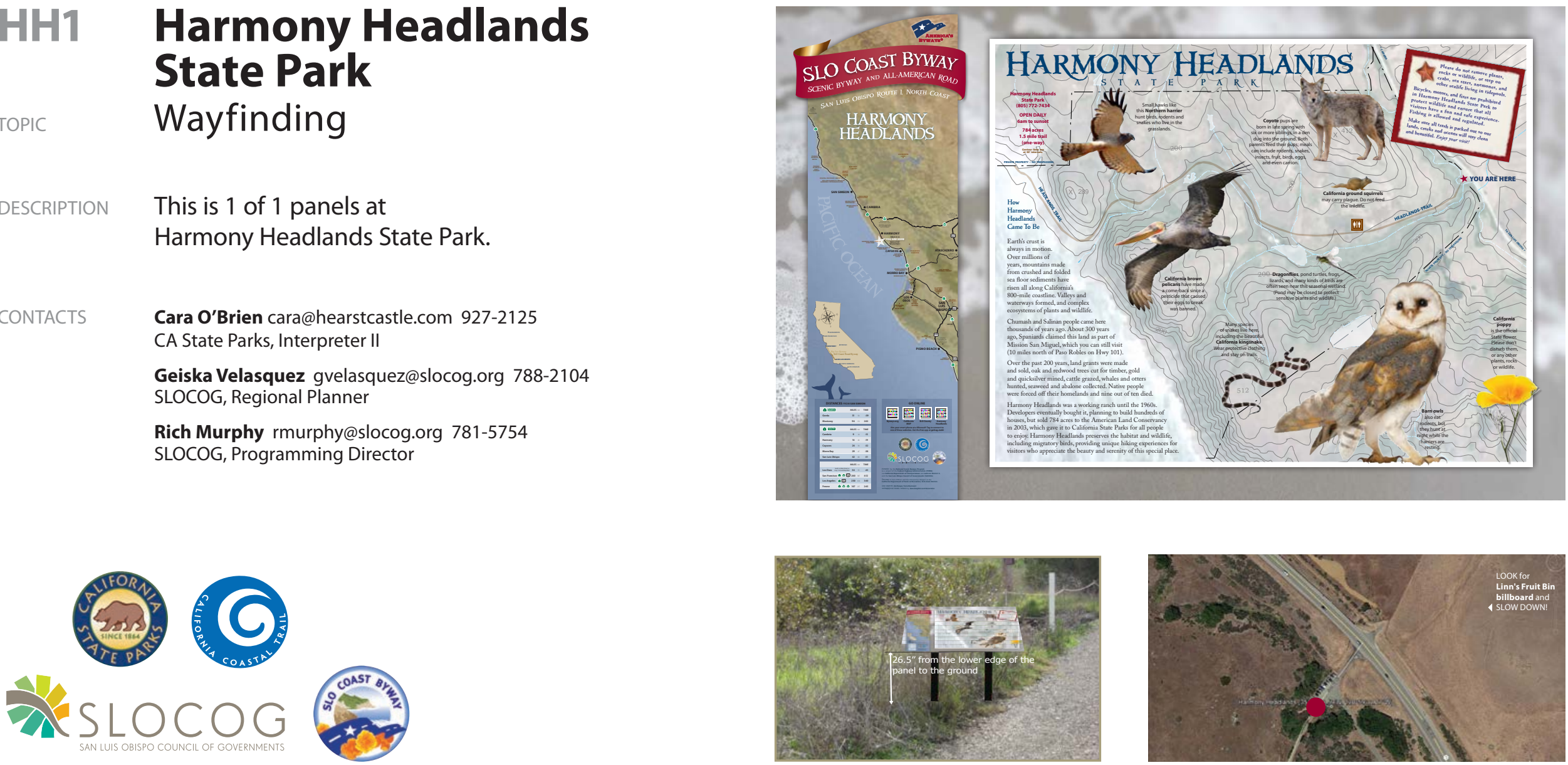

\begin{tabular}{|c|c|c|c|}
\hline \multirow{3}{*}{ 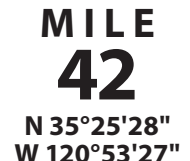 } & NAME HARMONY HEADLANDS STATE PARK & FILE NAME BY.HH1-HarmonyHeadlands & CELL MAYBE \\
\hline & LOCATION HARMONY HEADLANDS STATE PARK - parking area & PARTNERS CA STATE PARKS-HEARST & PERMIT YES \\
\hline & LANDOWNER CA STATE PARKS & MANAGERS CARA O'BRIEN & BASE DIRT \\
\hline
\end{tabular}




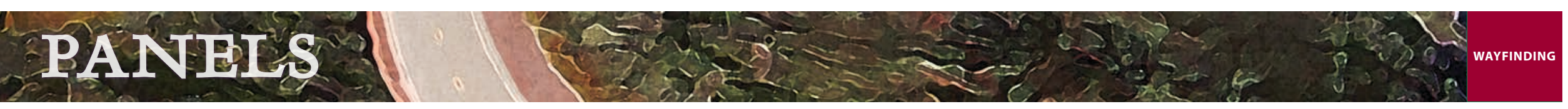

\section{CCT1 California Coastal Trail \\ TOPIC Wayfinding}

DESCRIPTION This is 1 of 1 panels about

the California Coastal Trail, and 2 of 2 panels in Cambria (with the Welcome panel).

CONTACTS Tim Duff tduff@scc.ca.gov (510) 286-3826

California Coastal Conservancy Project Manager

Cara O'Brien cara@hearstcastle.com 927-2125

CA State Parks, Interpreter II

Geiska Velasquez gvelasquez@slocog.org 788-2104 SLOCOG, Regional Planner

Rich Murphy rmurphy@slocog.org 781-5754

SLOCOG, Programming Director
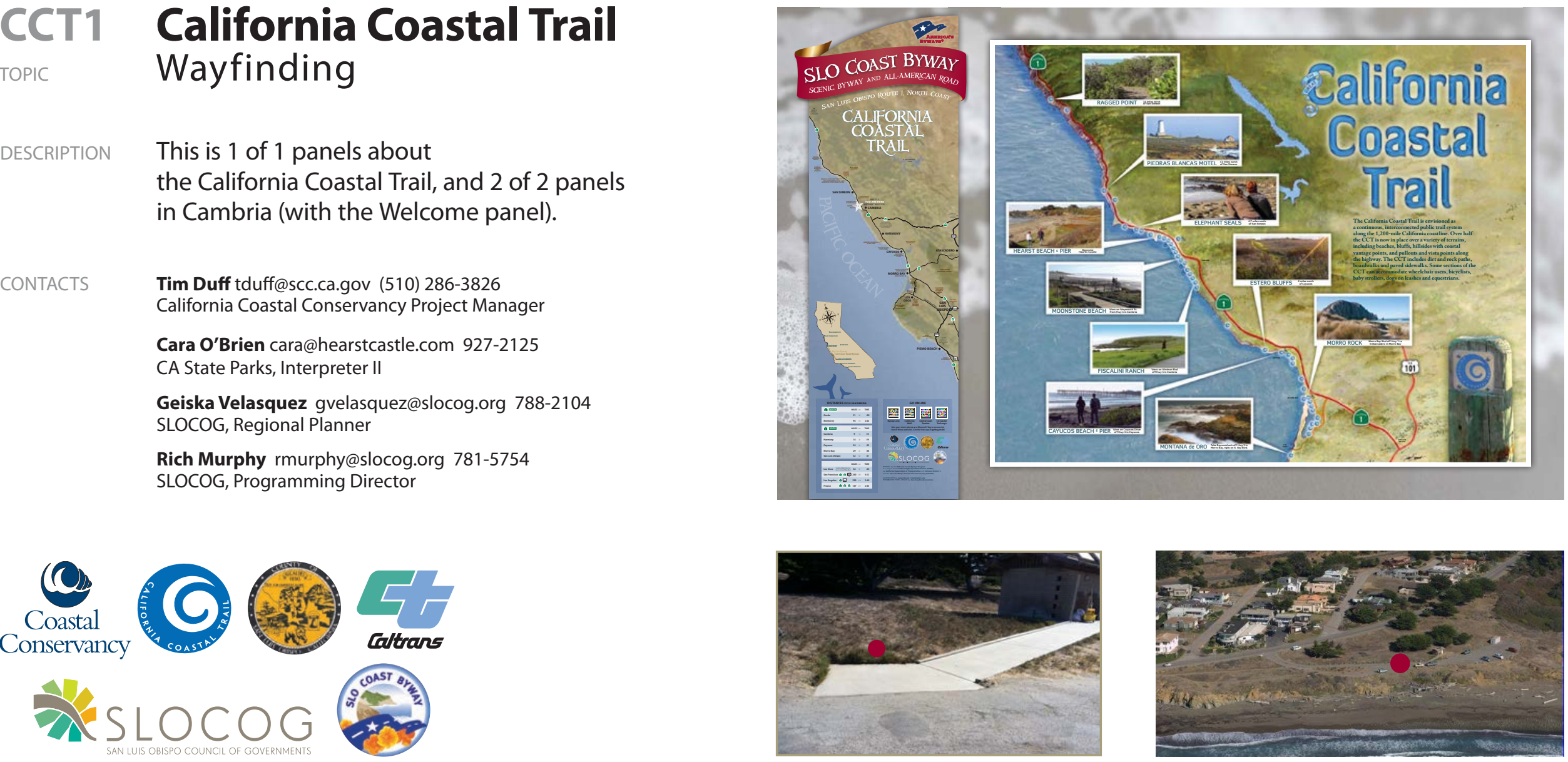

\begin{tabular}{|c|c|c|c|}
\hline \multirow{3}{*}{$\begin{array}{c}\text { M I L E } \\
51 \\
\text { N 35⒊' } \\
\text { W 121 } 126^{\circ} 29^{\prime \prime}\end{array}$} & NAME CALIFORNIA COASTAL TRAIL & FILE NAME BY.CCT1-trails & CELL MAYBE \\
\hline & LOCATION SAN SIMEON STATE PARK-SANTA ROSA CREEK, restroom ramp & PARTNERS CA COASTAL CONSERVANCY & PERMIT YES \\
\hline & LANDOWNER CA STATE PARKS & MANAGERS TIM DUFF, CARA O'BRIEN & BASE DIRT \\
\hline
\end{tabular}




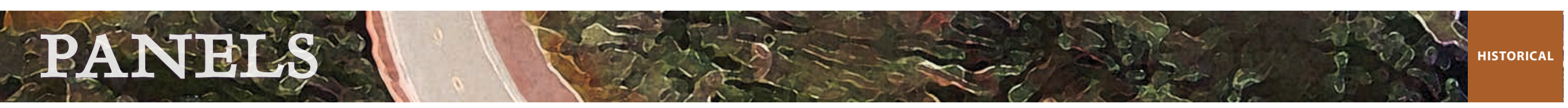

\section{PIC01 The Pale Strangers \\ TOPIC}

DESCRIPTION

This panel is 2 of 3 at Pico Creek Rd on the west side of the Highway.

Indigenous People traveled the coastal trail for thousands of years before Portola made the trip in 1769.

Renee Lundy rlundy@sansimeoncsd.org 927-4778 Charles Grace, Michele Roest

San Simeon CSD

Geiska Velasquez gvelasquez@slocog.org 788-2104 SLOCOG, Regional Planner

Rich Murphy rmurphy@slocog.org 781-5754 SLOCOG, Programming Director
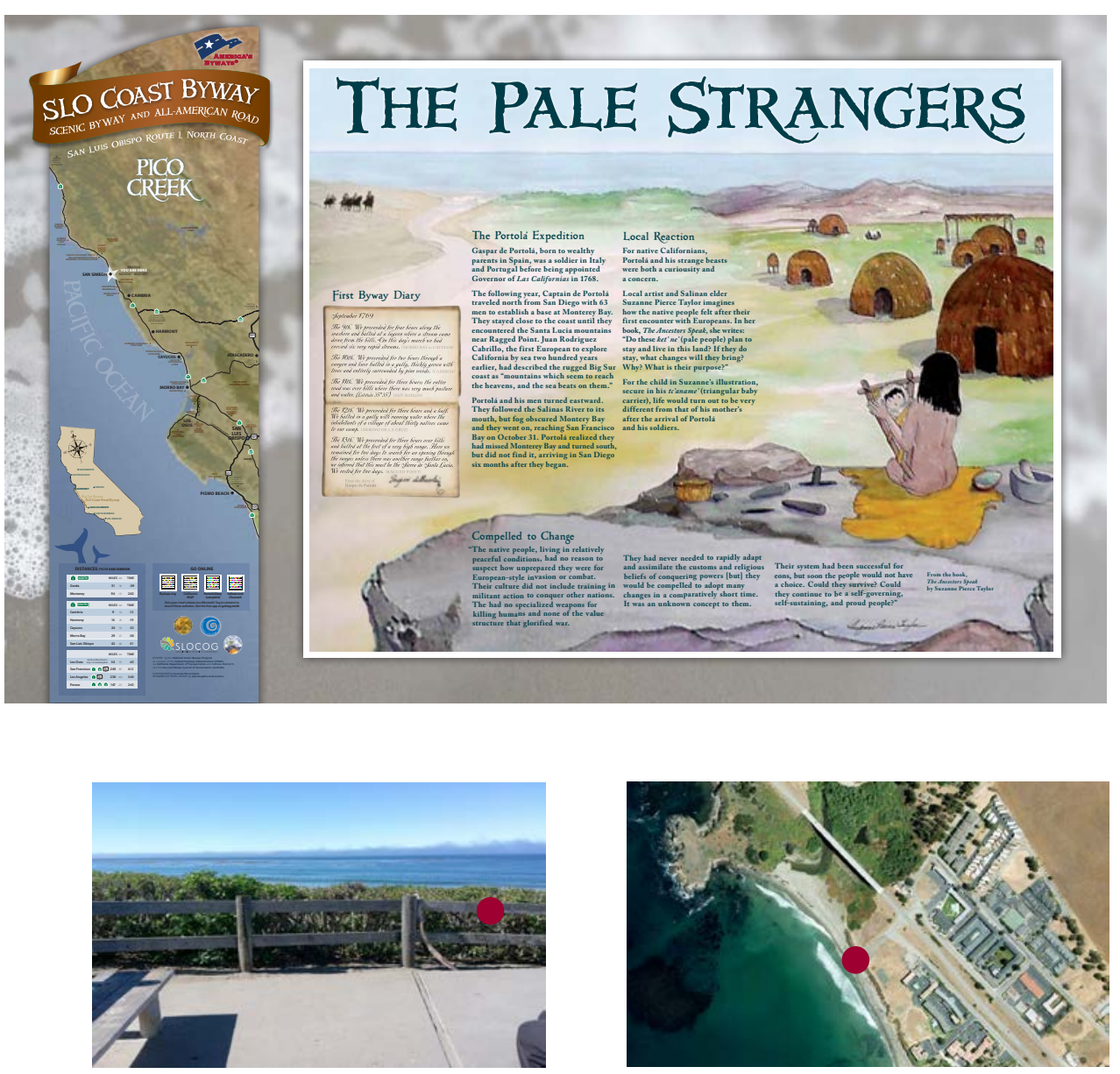

\begin{tabular}{|c|c|c|c|}
\hline \multirow{2}{*}{$\begin{array}{c}\text { M I LE } \\
55\end{array}$} & NAME THE PALE STRANGERS & FILE NAME BY.PICO1-native & CELL YES \\
\hline & LOCATION PICO CREEK RD & PARTNER SAN SIMEON COMMUNITY SERVICE DISTRICT & PERMIT YES \\
\hline $\begin{array}{l}N 35^{\circ} 36^{\prime} 52^{\prime \prime} \\
\text { W } 121^{\circ} 8^{\prime} 45^{\prime \prime}\end{array}$ & LANDOWNER SAN SIMEON COMMUNITY SERVICE DISTRICT & MANAGER RENEE LUNDY & BASE DIRT \\
\hline
\end{tabular}




\section{$\mathrm{PICO} 2$}

TOPIC

DESCRIPTION

This panel is 3 of 3 at Pico Creek Rd on the west side of the Highway.

CONTACTS

Renee Lundy rlundy@sansimeoncsd.org 927-4778 Charles Grace, Michele Roest

San Simeon CSD

Geiska Velasquez gvelasquez@slocog.org 788-2104 SLOCOG, Regional Planner

Rich Murphy rmurphy@slocog.org 781-5754

SLOCOG, Programming Director
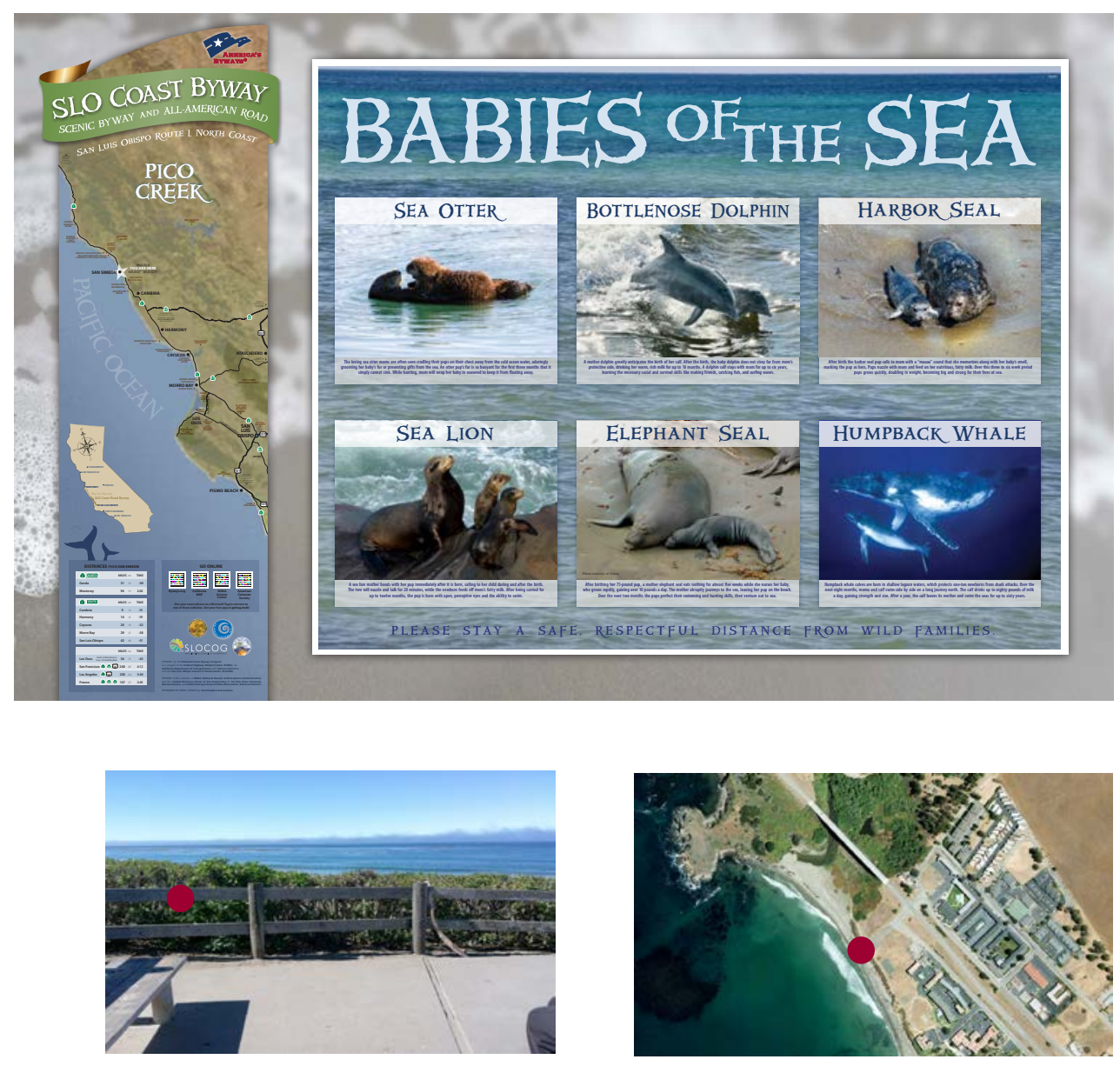

\begin{tabular}{|c|c|c|c|}
\hline \multirow{2}{*}{$\begin{array}{c}\text { M I LE } \\
55\end{array}$} & NAME BABIES of the SEA & FILE NAME BY.PICO2-mombaby & CELL YES \\
\hline & LOCATION PICO CREEK RD & PARTNER SAN SIMEON COMMUNITY SERVICE DISTRICT & PERMIT YES \\
\hline W $121^{\circ} 88^{\prime} 45^{\prime \prime}$ & LANDOWNER SAN SIMEON COMMUNITY SERVICE DISTRICT & MANAGER RENEE LUNDY & BASE DIRT \\
\hline
\end{tabular}




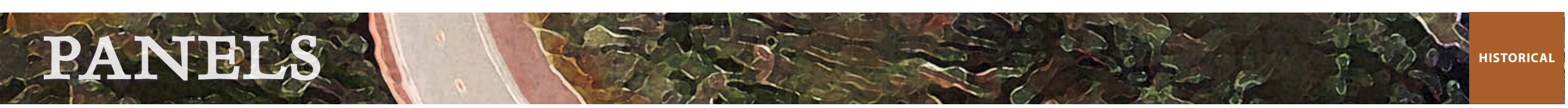

\section{NA}

TOPIC

DESCRIPTION

\section{One Wild Ride The History of Highway 1}

Caltrans' historic photos of the building of Highway 1. This panel will be constructed by Caltrans, along with the Piedras Blancas Light Station panel.

CONTACTS Bob Carr Bob.Carr@dot.ca.gov 549-3083

Caltrans, Scenic Byway Coordination, Landscape Architect

Corby Kilmer Corby.Kilmer@dot.ca.gov 549-3509, 542-4746 Caltrans, Landscape Architect, Public Outreach

Paula Juelke Carr Paula.Carr@dot.ca.gov 542-4659

Caltrans, Associate Environmental Planner, Architectural History

Raymond Yamamoto Ray.Yamamoto@dot.ca.gov 549-3082

Caltrans, Design II Archive Manager (Gayle Hayes)

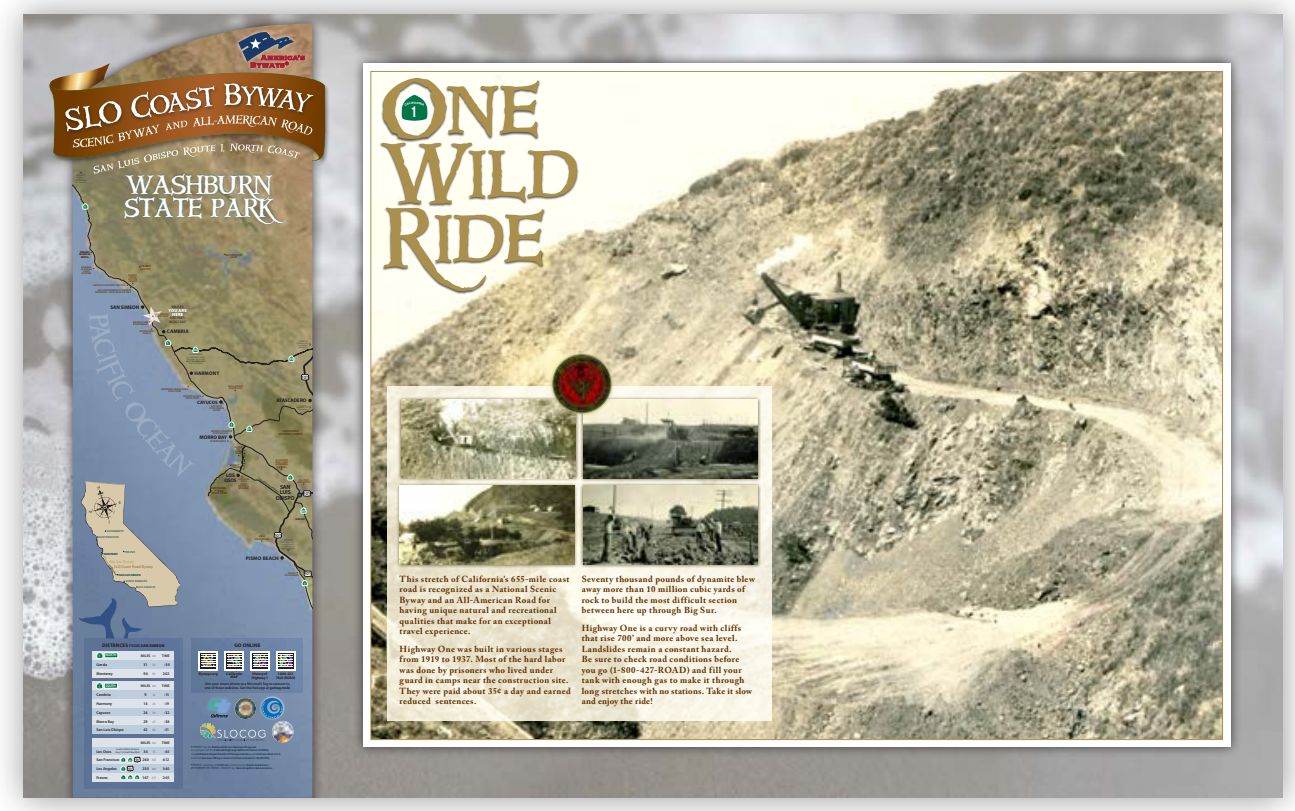

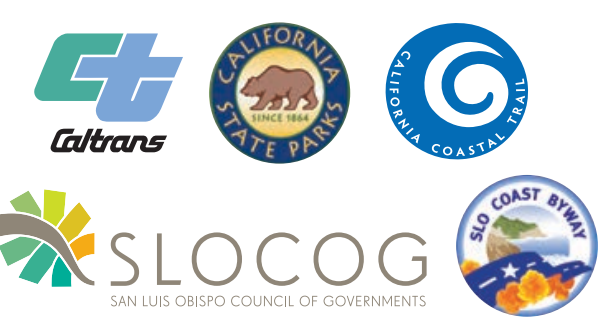

\begin{tabular}{|c|l|l|l|}
\hline \multirow{2}{*}{$\begin{array}{c}\text { M I LE } \\
\mathbf{N} \mathbf{3} 3.5947 \\
\mathbf{W} \mathbf{1 2 1 . 1 2 4 4}\end{array}$} & NAME HIGHWAY INTO HISTORY & FILE NAME BY.NA-highwayone \\
\cline { 2 - 4 } & LOCATION UNKNOWN & PARTNERS CALTRANS? & CELL \\
\cline { 2 - 4 } & & MANANAGERS NA & BASE SAND \\
\hline
\end{tabular}


NA

TOPIC

DESCRIPTION

CONTACTS

\section{Lighting the Way}

Piedras Blancas Light Station

This panel will be constructed by Caltrans, along with the History of Highway 1 panel.

Jim Boucher jboucher@ca.blm.gov 927-2968 BLM, Piedras Blancas Light Station Manager

Cara O’Brien cara@hearstcastle.com 927-2125

CA State Parks, Interpreter II

Doug Barker dbarker@hearstcastle.com 927-2125 CA State Parks, Interpreter II

Geiska Velasquez gvelasquez@slocog.org 788-2104 SLOCOG, Regional Planner

Rich Murphy rmurphy@slocog.org 781-5754

SLOCOG, Programming Director
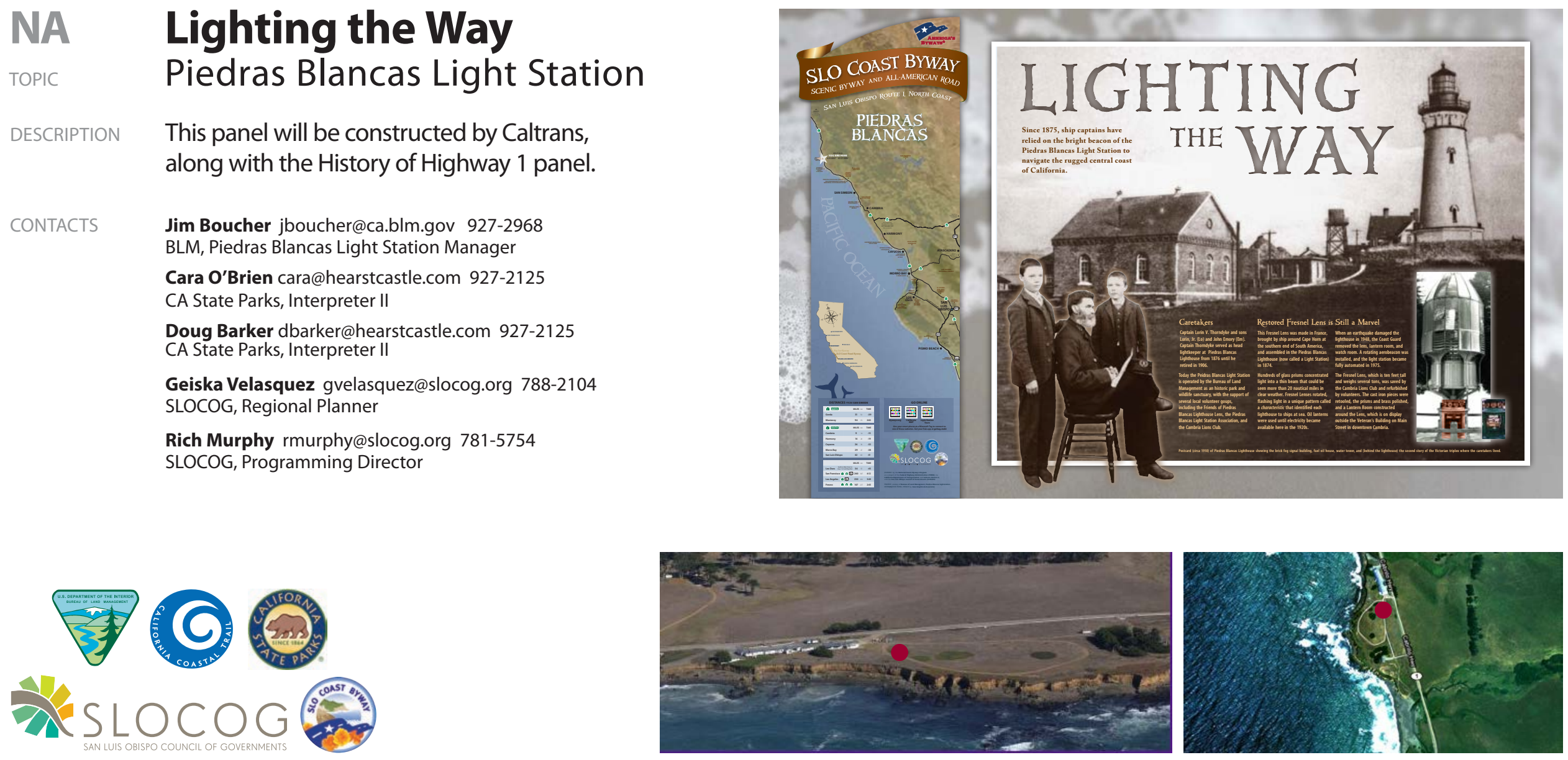

\begin{tabular}{|c|c|c|c|}
\hline & NAME LIGHTING THE WAY & FILE NAME BY.NA-lightstation & CELL \\
\hline & LOCATION UNKNOWN & PARTNERS CALTRANS? & PERMIT \\
\hline W 121.2880 & LANDOWNER NA & MANAGERS NA & BASE SAND \\
\hline
\end{tabular}




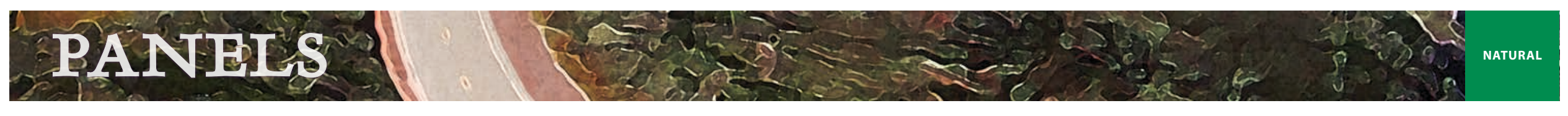

\section{NA Conserving California's Coastal Treasures \\ TOPIC Marine Protected Areas}

DESCRIPTION This panel has been canceled. The panel content was provided by the Monterey Bay Sanctuary Foundation.

CONTACTS Carolyn Skinder carolyn.skinder@noaa.gov 927-2145 NOAA, Outreach \& Education Specialist
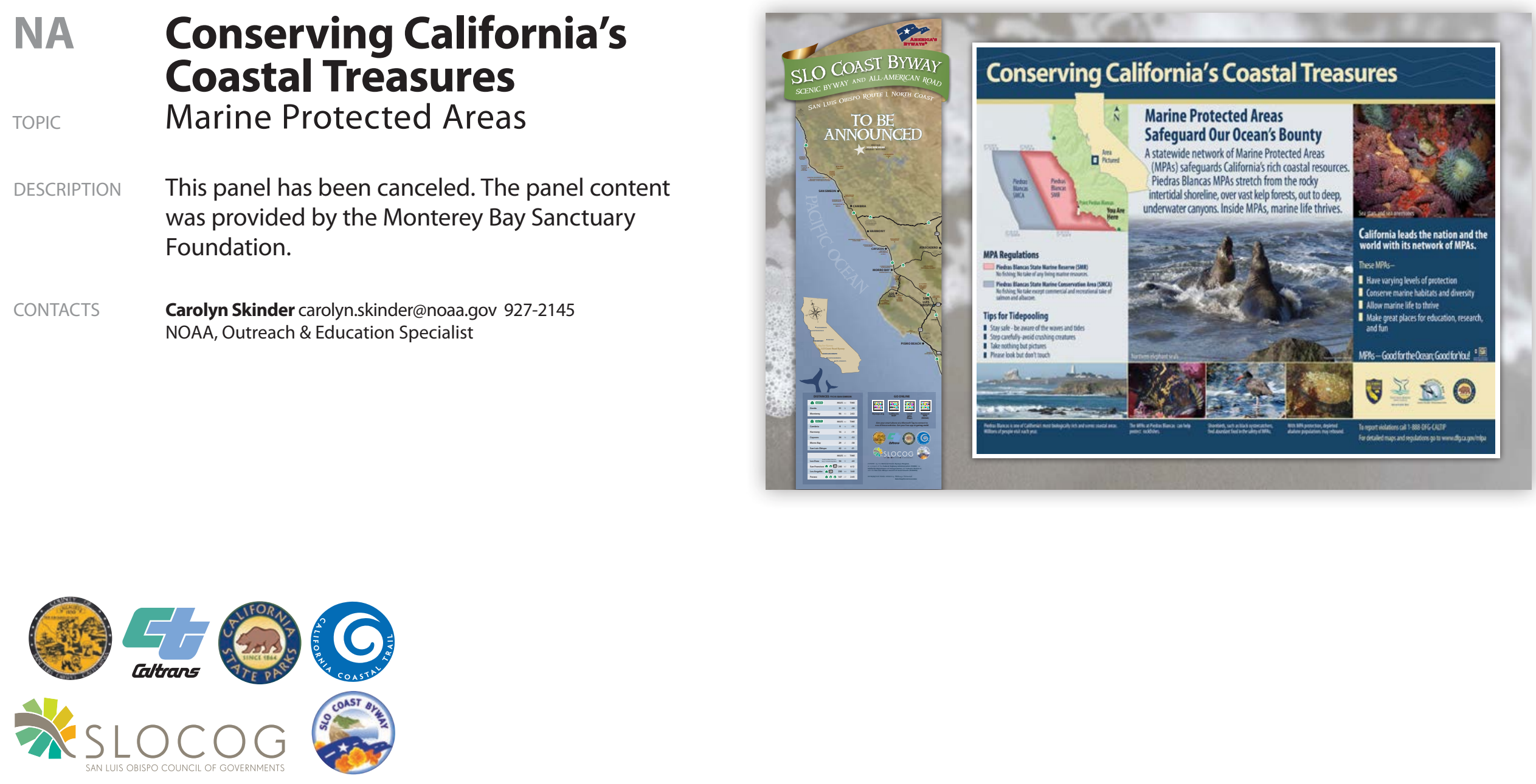

\begin{tabular}{|l|l|l|l|}
\hline $\begin{array}{c}\text { M I L E } \\
\mathbf{6} \\
\mathbf{N} \mathbf{N} \mathbf{3} \mathbf{3} . \mathbf{6} 330 \\
\mathbf{W} \mathbf{1 2 1 . 2 4 2 3}\end{array}$ & NAME CONSERVING CALIFORNIA'S COASTAL TREASURES & FILE NAME BY.NA-MPA & CELL \\
\cline { 2 - 4 } & LOCATION NA & PARTNERS NOAA & PERMIT \\
\hline
\end{tabular}




\section{PANELS}

\section{NA}

TOPIC

DESCRIPTION

\section{Welcome to the CCNM CA Coastal National Monument}

This panel has been canceled.

BLM-CCNM created this panel with facts about sea birds and sea mammals who inhabit offshore rocks along the coast, part of the 1,100 mile California Coastal National Monument operated by BLM.

Marcia deChadenedes mdechade@ca.blm.gov (831) 372-6225 BLM, Coastal National Monument Manager

Josh Hammari jhammari@blm.gov (916) 978-4633 BLM Graphic Designer
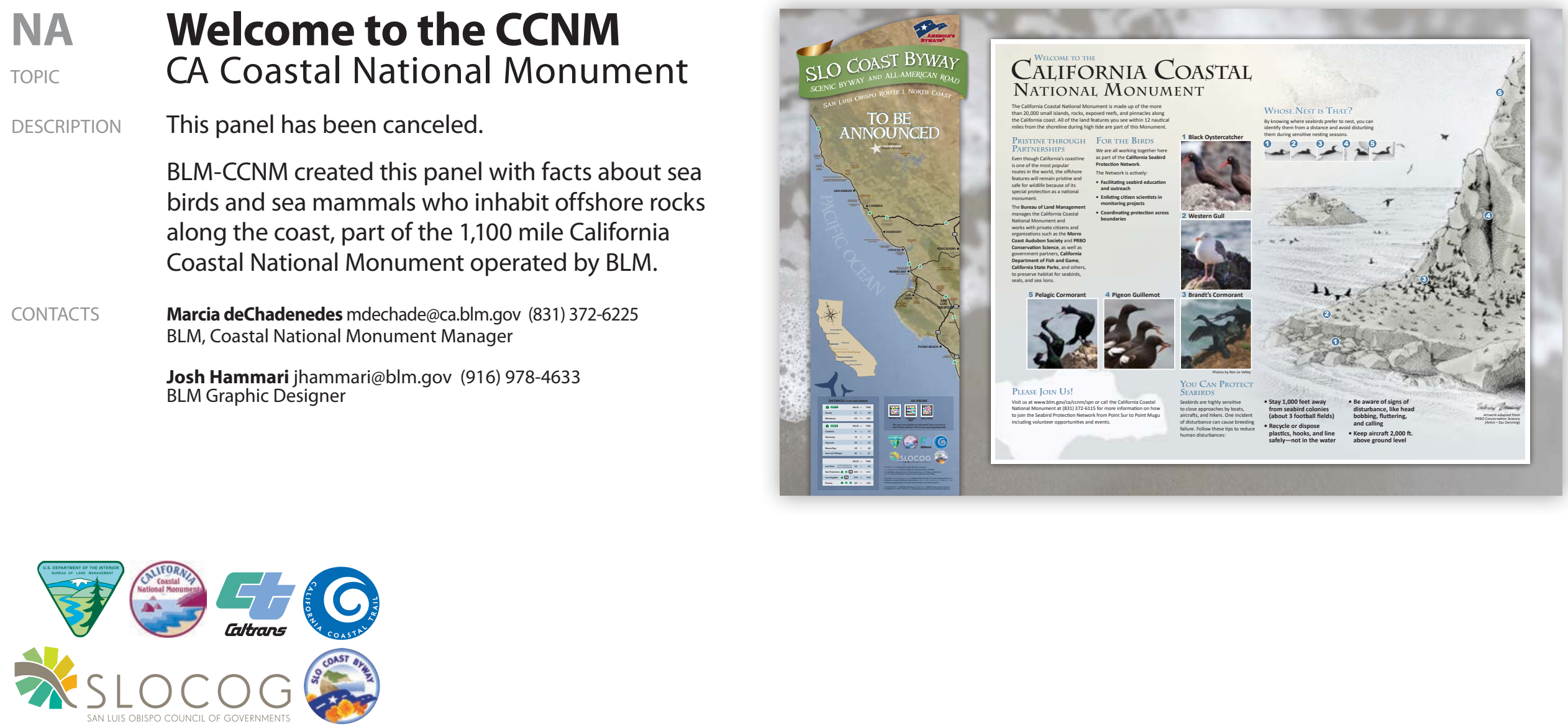

\begin{tabular}{|c|c|c|c|}
\hline \multirow{3}{*}{$\begin{array}{c}\text { M I L E } \\
62.5 \\
\text { N } 35.6629 \\
w 121.2568\end{array}$} & NAME WELCOME TO THE CCNM & FILE NAME BY.NA-CCNM & CELL \\
\hline & LOCATION NA & PARTNERS BLM-CCNM & PERMIT \\
\hline & LANDOWNER NA & MANAGERS & BASE SAND \\
\hline
\end{tabular}



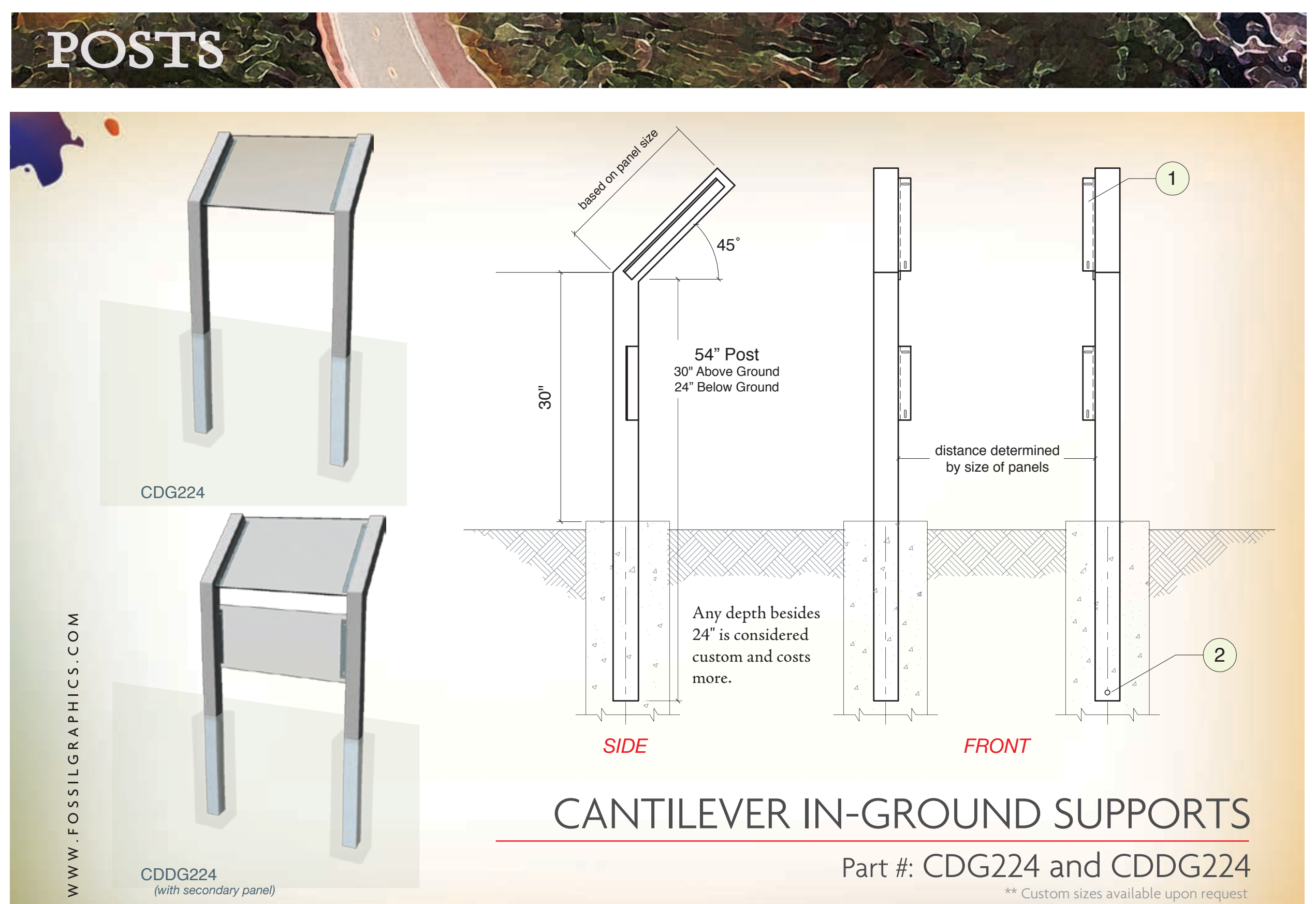

\section{CANTILEVER IN-GROUND SUPPORTS}

Part \#: CDG224 and CDDG224 


\section{POSTS}
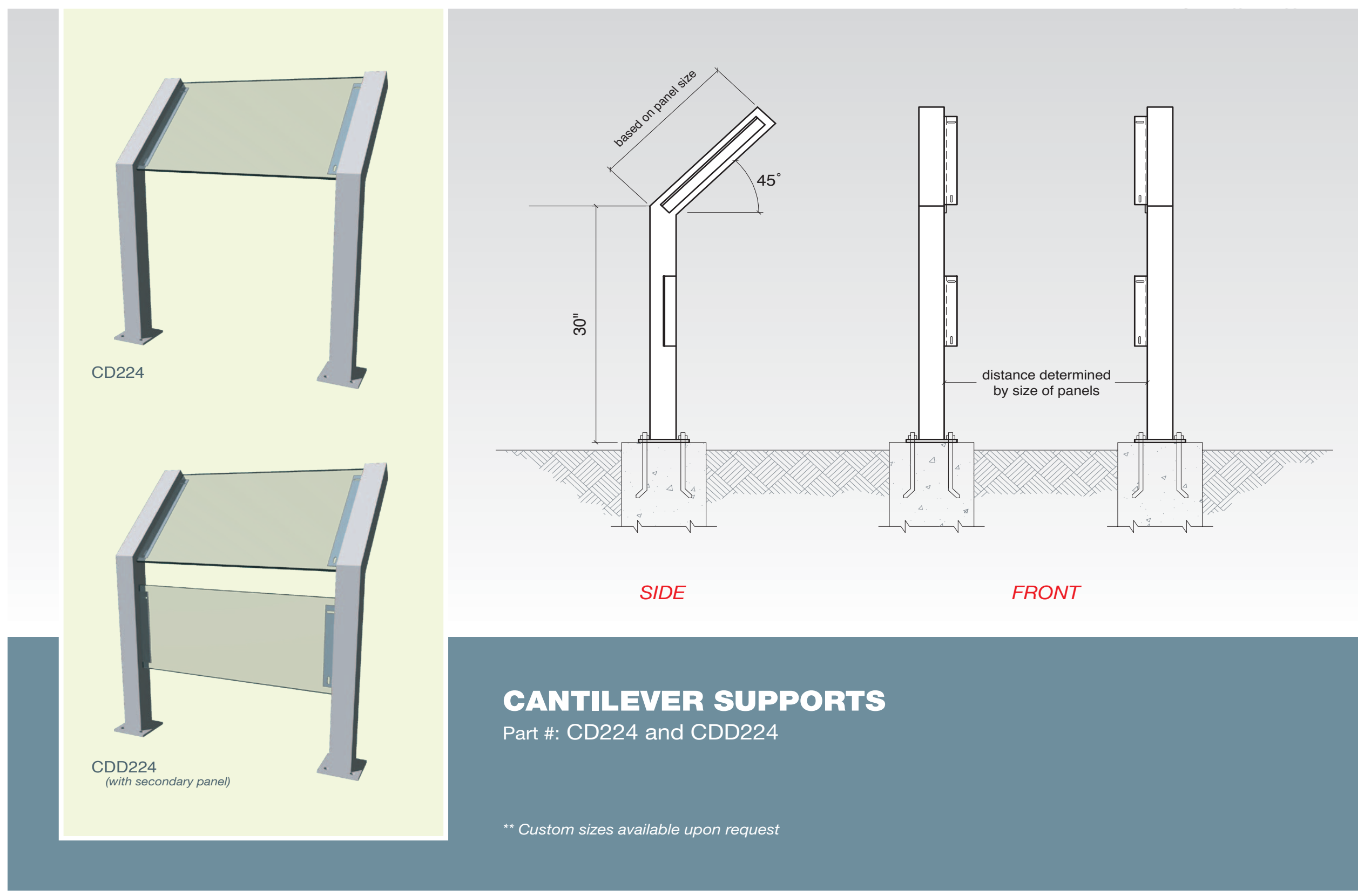

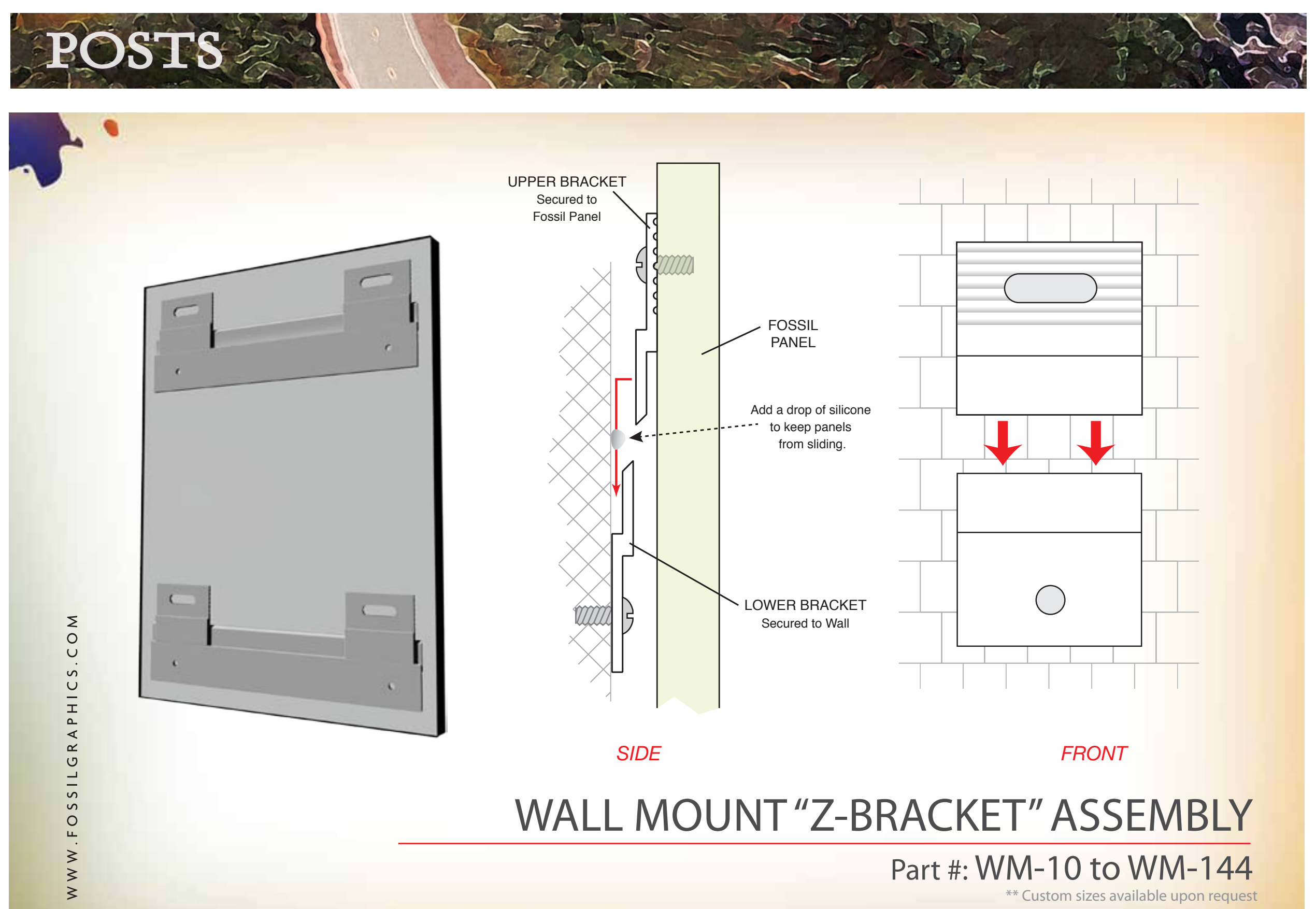

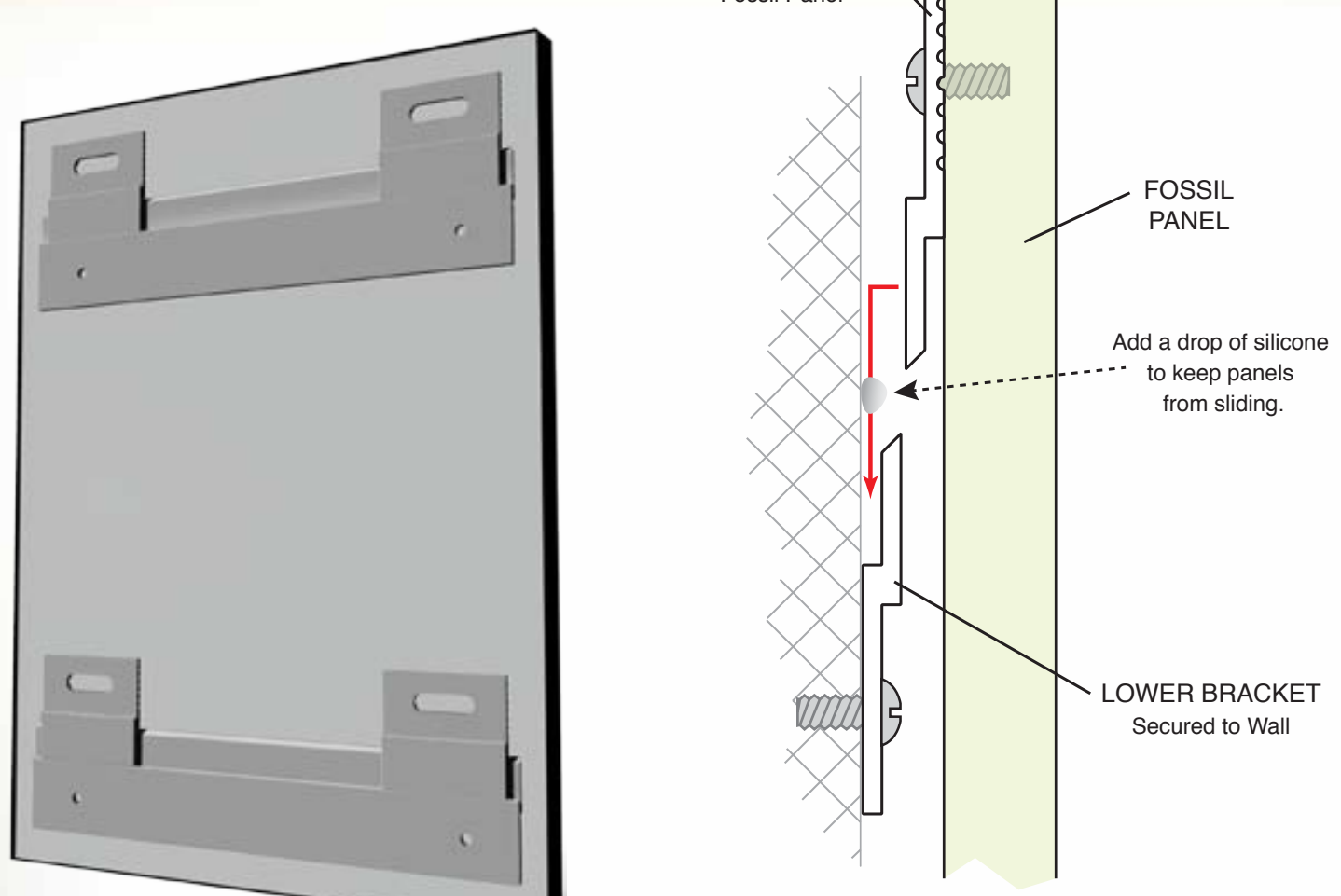

SIDE

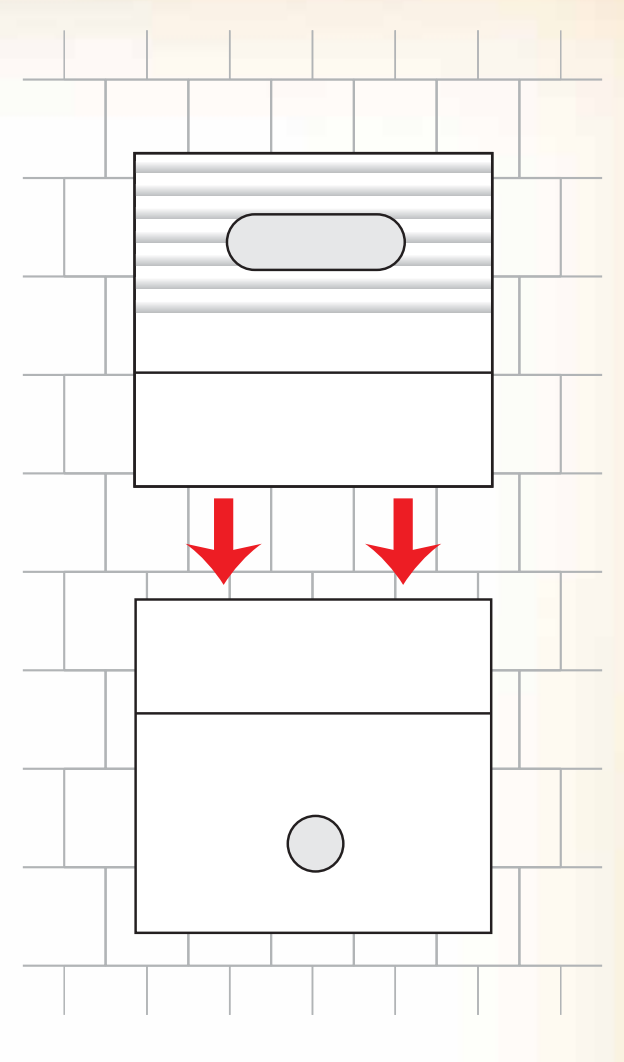

FRONT

WALL MOUNT"Z-BRACKET" ASSEMBLY

Part \#: WM-10 to WM-144

** Custom sizes available upon request 


\section{PROOFS}

लkan

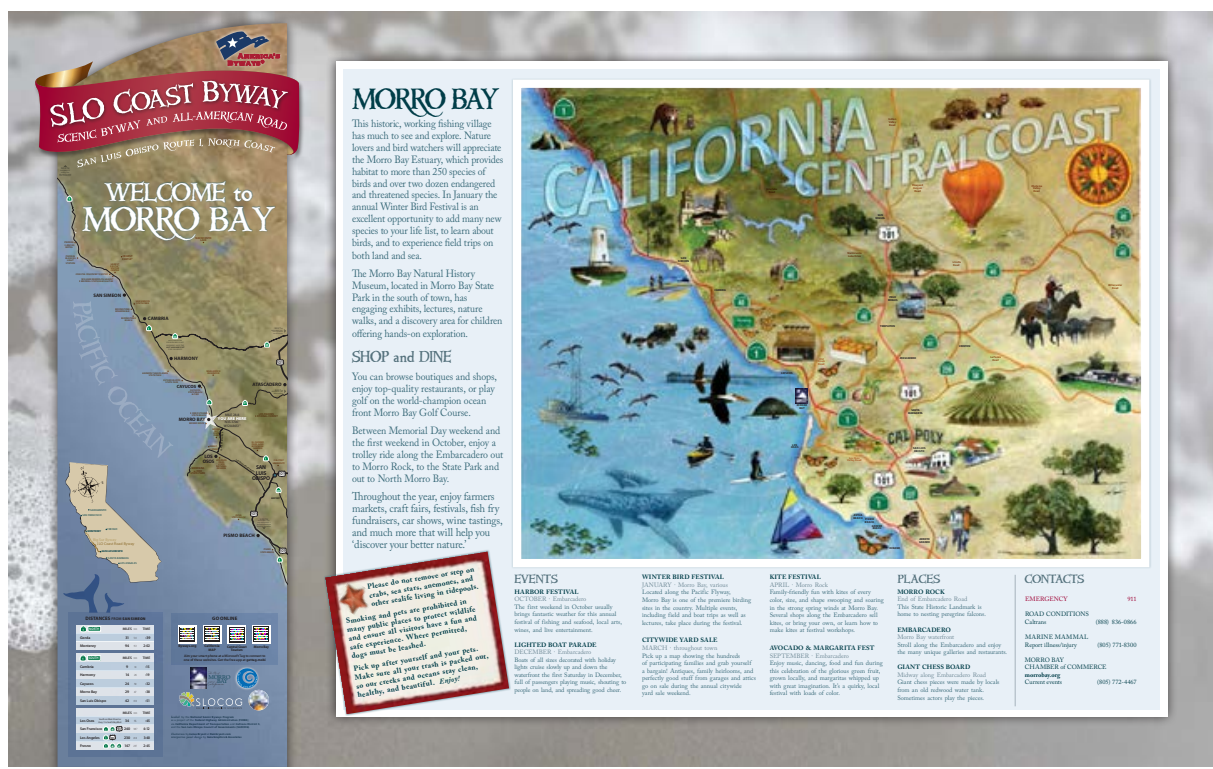

BY.W1-MorroBay

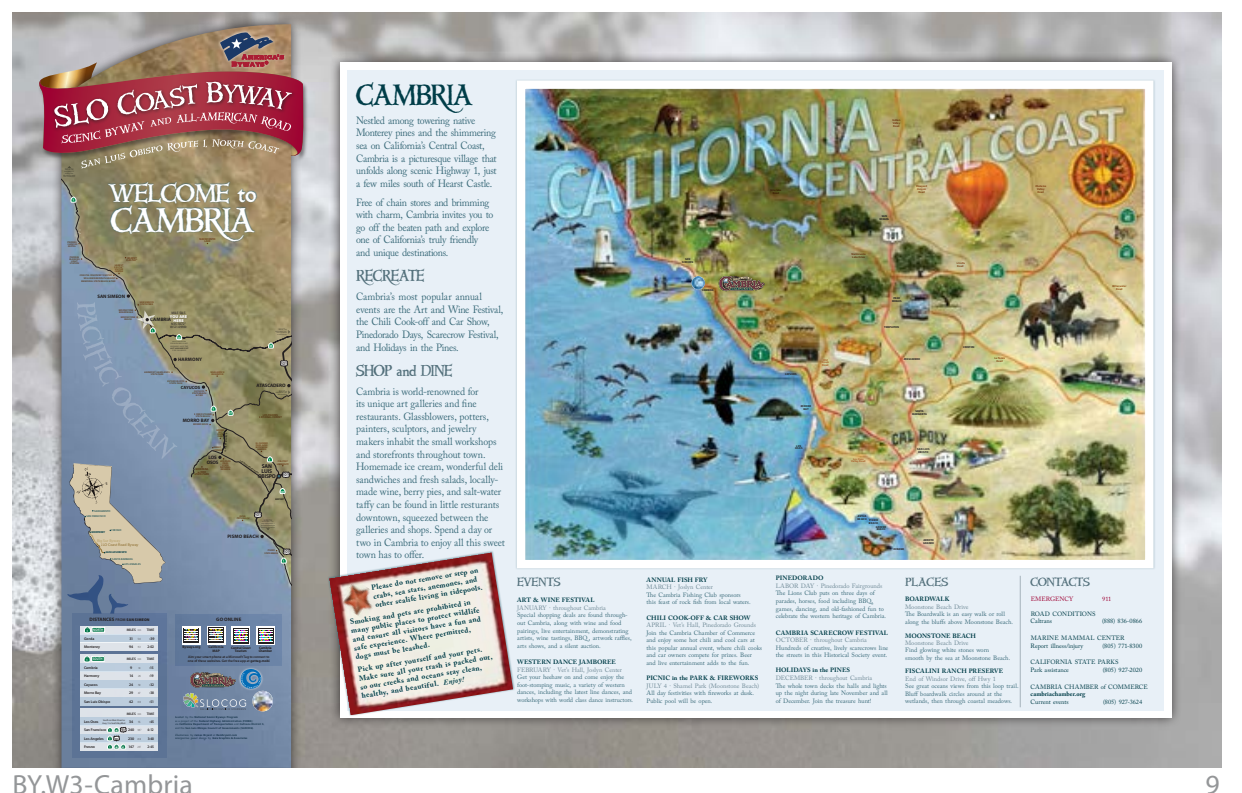

29

BYWAY INTERPRETIVE SIGNAGE PLAN | Route 1, San Luis Obispo North Coast Byway
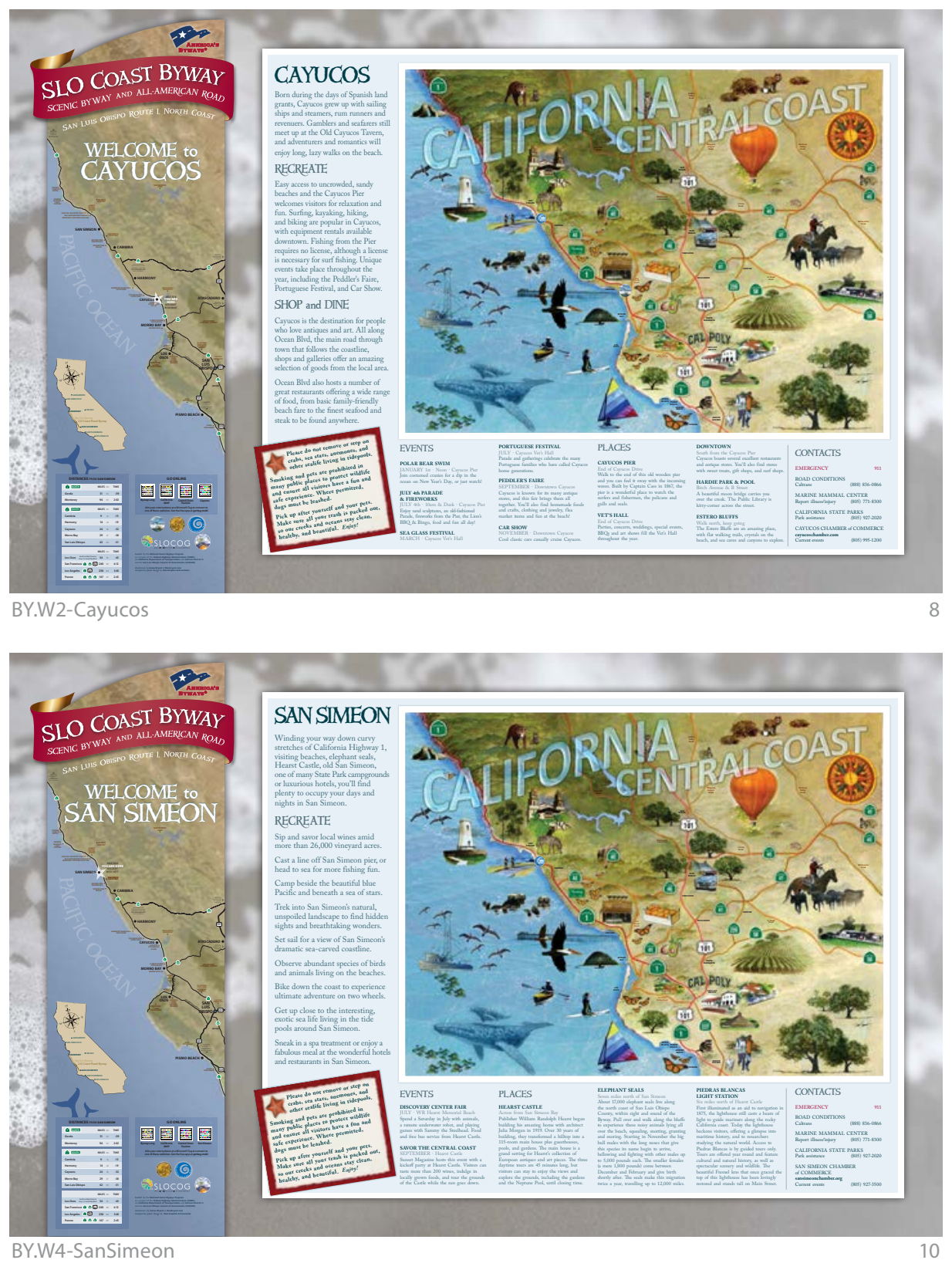

UPDATED: October 29, 2013 

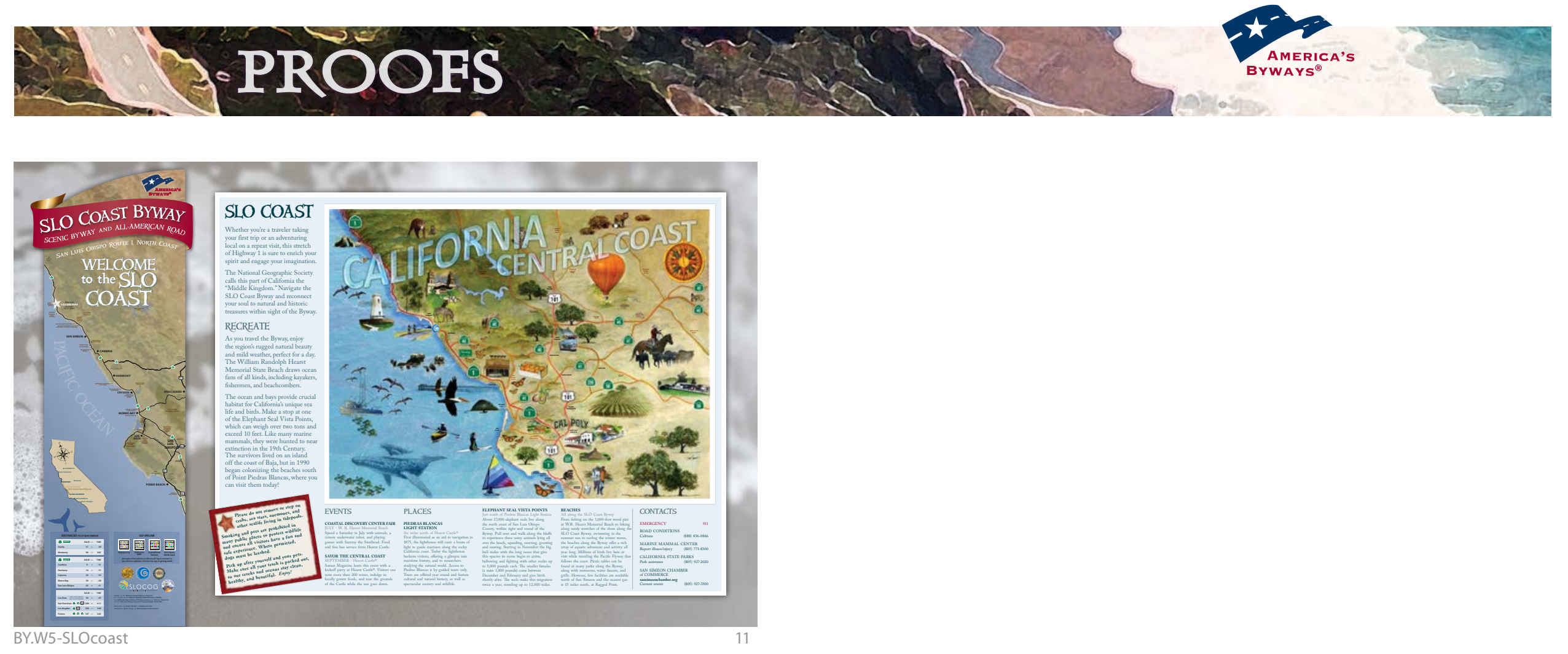


\section{PROOFS}
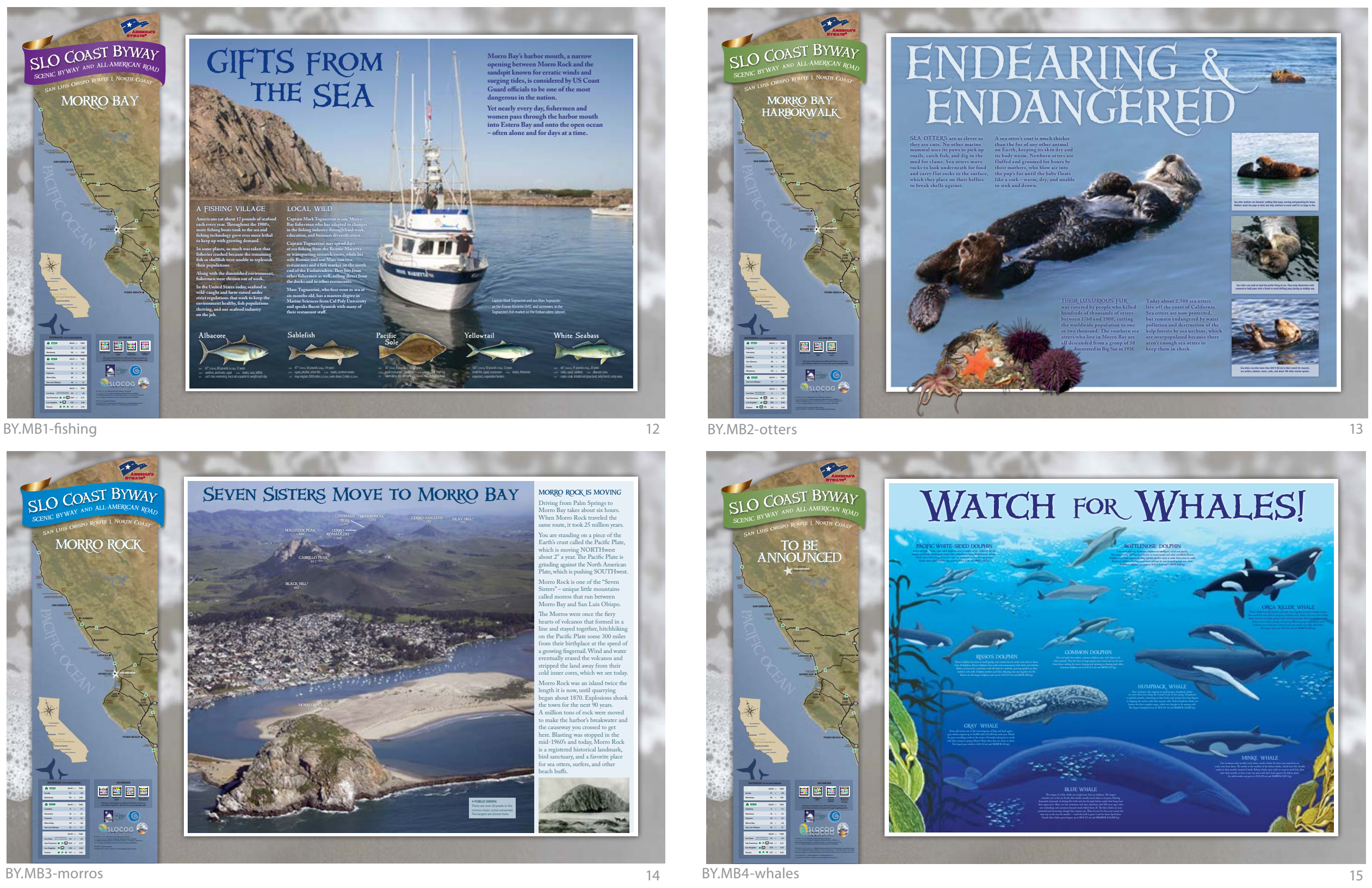


\section{PROOFS}
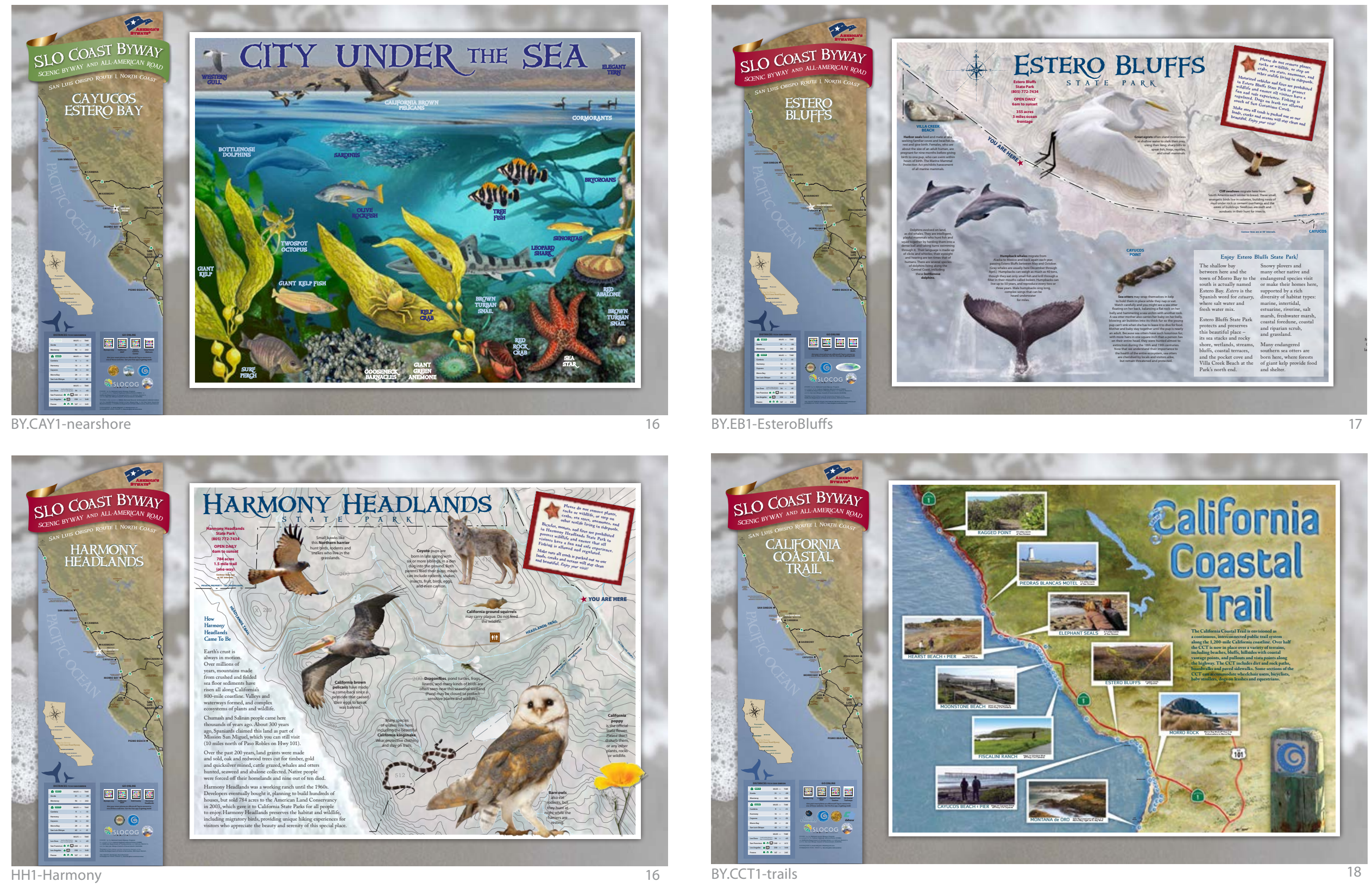


\section{PROOFS}
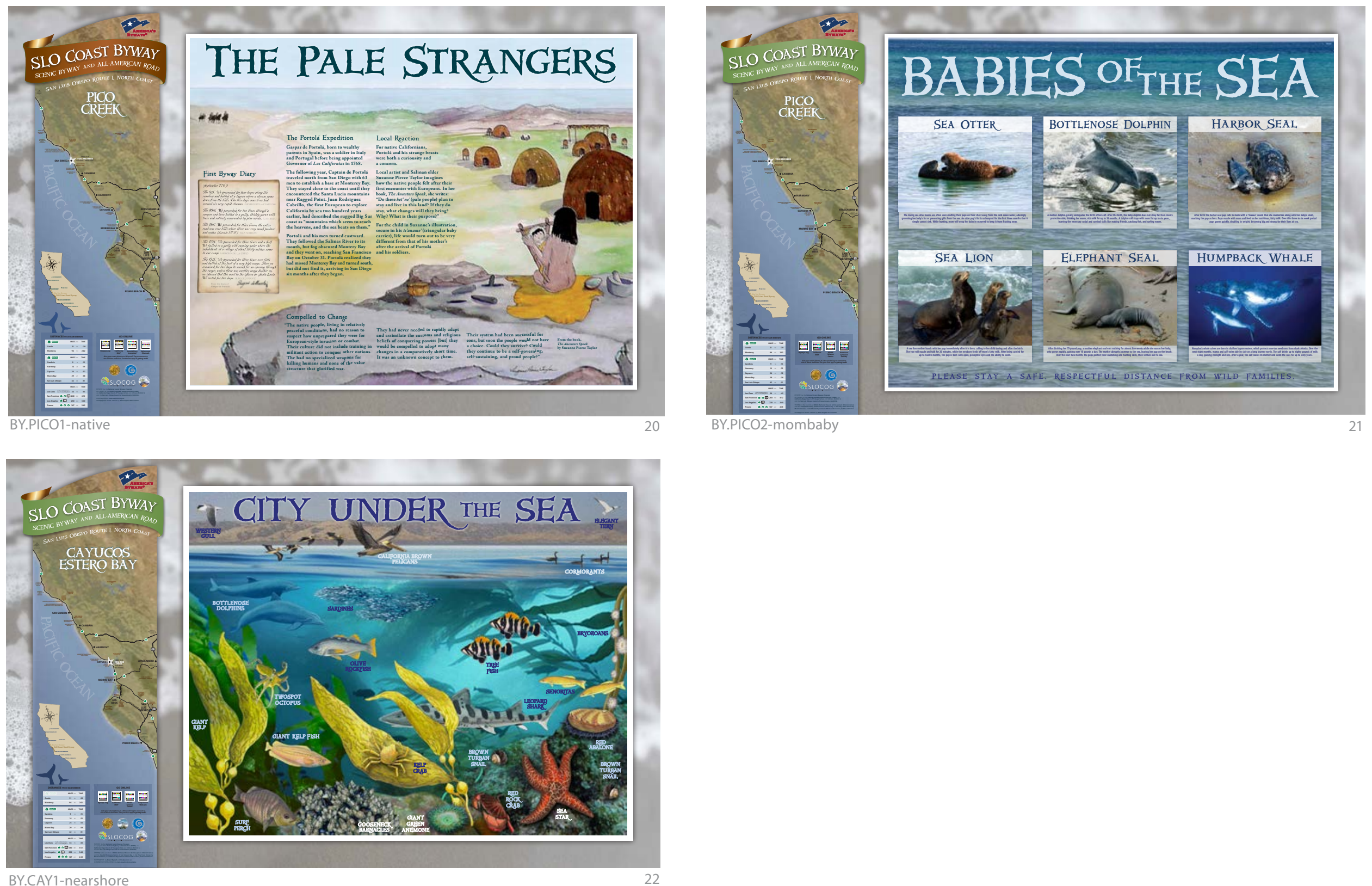

BYWAY INTERPRETIVE SIGNAGE PLAN | Route 1, San Luis Obispo North Coast Byway 


\section{SLO Coast BVWay}
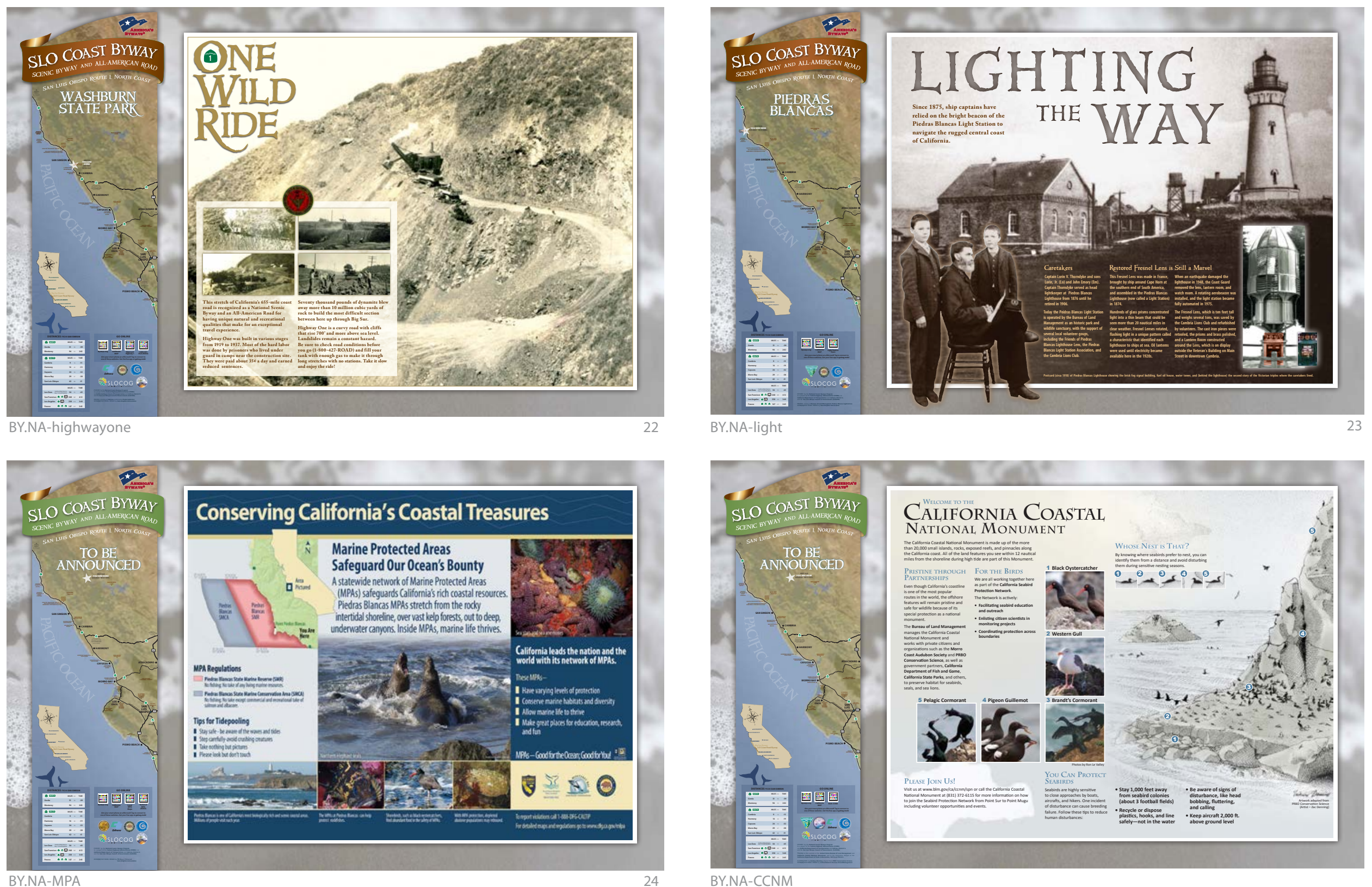

BYWAY INTERPRETIVE SIGNAGE PLAN | Route 1, San Luis Obispo North Coast Byway 


\section{APPENDIX B}

\section{Summary of Framework of Protections}




\section{Framework for Protection of Scenic Resources}

In 1972, the voters of California passed Proposition 20, known as the Coastal Initiative, which established the California Coastal Act. Among other things, the Coastal Act designated a "Coastal Zone," along the coastal fringe from Oregon to Mexico. The coastal zone is subject to more stringent guidelines having to do with the development patterns and visual resources.

As a result of the Coastal Act, local jurisdictions are required to prepare local coastal plans (LCP's) containing a Coastal Zone Land Use Ordinance (CZLUO) to incorporate state-mandated coastal protections into their General Plans. Once the Commission certifies a jurisdiction's LCP it is deemed to be in compliance with these stricter guidelines. Following certification, local jurisdictions assume permitting authority from the Commission. However, most building permits issued by the County or City within the coastal zone is appealable to the Commission.

Both the County of San Luis Obispo and the City of Morro Bay have certified Local Coastal Plans. This means their zoning and allowable land use ordinances have been deemed to be in compliance with the spirit and letter of the Coastal Act.

The following provides a summary of the regulatory framework that has been adopted to protect the scenic resources of the corridor. The San Luis Obispo County and City of Morro Bay's Corridor Protection Plans are included in Appendix $A$ and $B$.

\section{San Luis Obispo County}

(See Appendix A for complete San luis Obispo County SCenic Highway Corridor Protection Plan)

Regulation of Land Use (density and allowable land uses) - Consistent with California Coastal Act.

A. Allowable uses are defined in the Coastal Zone Framework for Planning Table "N"

- Site Planning (review authority for proposed developments)

- Minor Use Permit Process- issued directly by County of SLO, appealable to the California Coastal Commission if within the Coastal Appealable zone.

- Development Plans - More complex projects, issued directly by County of SLO, appealable to the California Coastal Commission if within the Coastal Appealable zone.

- General Plan Amendments and Area Plan Updates - require comprehensive EIR's and public hearings. Updates and amendments require the Coastal Commission certification before taking effect.

- The California Coastal Commission - final permit authority in the Coastal Zone.

\section{Coastal Zone Land Use Ordinance}

Prohibition of off-site outdoor advertising, and control of on-site advertising

Sec. 23.04.306(c) Prohibited Signs and Sign Materials. Any off-premise sign that directs attention to a business, service, product, or entertainment not sold or offered on the premises on which the sign is located, including but not limited to billboards and other offpremise outdoor advertising signs."

Control of earthmoving and landscaping (grading ordinances, landscaping requirements)

Sec. 23.05.030(e.3) The proposed grading will not create substantial adverse long-term effects visual effects visible from off-site.

Design and appearance of structures and equipment (utility structures, etc.)

Sec. 23.08.286

Where feasible, utility lines shall be under grounded when their placement would limit or detract from views of the ocean from collector or arterial roads. All other cases, they shall be sited to minimize their visibility from public roads' 
Sec. 23.08.288

addresses screen, revegetation and landscaping during and after construction.

\section{City of Morro Bay}

Policies and Programs Relating to Protection of Scenic Qualities

(See Appendix B for complete Morro Bay Scenic Highway Corridor Protection Plan)

- $\quad$ Regulation of Land Use (density and allowable land uses) - Consistent with California Coastal Act of 1976.

a Certified Local Coastal Program Land Use Plan and implementing ordinances contained in three documents.

- Policies and programs defined in the City General Plan Elements

- Standards for land use regulations defined in the Morro Bay Municipal Code

- North Main Street Specific Plan

Visual Resource Element

Policy VR-1 The City will establish a system of scenic roadways and a set of mechanisms to protect their scenic values.

Policy VR-2 The scenic and visual qualities of the coastal areas shall be considered and protected as a resource of public importance. Permitted development shall be sited and designed to protect public views to and along the ocean and scenic and coastal areas, to minimize the alteration of natural landforms, to be visually compatible with the character of the surrounding area, and where feasible, to restore and enhance visual quality in visually degraded areas.

Policy VR-3 The City shall implement the Coastal Land Use Plan/Coastal Element map and policies, through the adoption of appropriate ordinances, to protect and enhance the visual resources associated with the corridors of the City's scenic highways and local designated routes.

\section{City of Morro Bay Municipal Code}

17.48.190 - Protection of Visual Resources and Compatible Design - New development shall protect and when feasible, enhance the visual quality of the surrounding area. New development may be permitted only if the siting and design meet that following standards:
A. Protection of public views
B. Protection of natural landforms
C. Compatibility
D. Visual quality
E. Scenic area standards
i. Character
ii. Height/Bulk
iii. Parks and Open Space
iv. View Corridors
v. Landscaping

17.68 - Prohibition of off-site outdoor advertising, and control of on-site advertising - Morro Bay Municipal Code Chapters- prohibits new billboards and governs the size and height of on-site outdoor advertising visible from the highway.

a Site Planning (review authority for proposed developments) 
- California Coastal Commission permit authority up to the mean high tide line.

- City of Morro Bay permit authority for remaining land within the Coastal Zone.

- Morro Bay Municipal Code Chapters 17.58 (Coastal Development Permits and Procedures)

- Morro Bay Municipal Code Chapters 17.60 (Use Permit Procedures, Notices and Variances)

- Visual Resource Element - to enhance, protect and preserve the existing and potential visual resources of Morro Bay and its surroundings (Policy VR-1)

- Program VR-1.4 City shall request Caltrans to develop a plan and program for landscaping the entire length of Rte 1 as it traverses through the community that would: 1) frame and protect important views, 2) screen unattractive views, 3) accentuate entrances to the City.

- Design and appearance of structures and equipment

- Energy/Industrial Development

- Policy 5.08 of the LCP Chapter 7 states: "The City will require that new pipelines and transmission lines are installed with suitable mitigation measures such as erosion control, revegetation, and other measures necessary to protect all scenic resources and habitat values.

\section{SLOCOG - Regional Transportation Plan}

- OBJ9: VISUAL ENHANCEMENT - Maintain and enhance quality aesthetic experiences along transportation corridors and surrounding landscapes.

- 9a - Encourage and coordinate efforts to establish programs and standards for the management of the aesthetic resources as seen from highways and railways.

- $9 \mathrm{~b}$ - Work with local jurisdictions and Caltrans to implement a Scenic Byway and Scenic Highway designation for State routes where applicable.

- 9c - Coordinate with Caltrans and local jurisdictions and other entities to encourage development of measures that provide a "sense of place" along transportation corridors through the use of distinctive signage, landscaping, walkways. Work with Caltrans, local jurisdictions, and transportation providers to develop transportation facilities and amenities that fit within the unique character of the community, providing landscaped medians and walkways along major multi-lane arterial highways, streets, and roadways.

- 9d - Coordinate with Caltrans and local jurisdictions to implement measures to protect and enhance the distinctiveness of the county's landscapes with appropriate landscape and screening measures along major transportation rights-of-way with native vegetation in rural areas and theme vegetation in urban areas.

- $9 e$ - Coordinate with Federal, State, and local jurisdictions and Caltrans to establish scenic/vista points on State Highways and appropriate regional routes that provide information on the region and historic resources.

- If - Facilitate the funding of aesthetic improvements through all available means including: a regional Transportation and Environmental Enhancement and Mitigation Program; project mitigation through the CEQA process; city and county regulatory powers; federal, state, and regional programs; city, county, and private funding. 
- $9 \mathrm{~g}$ - Encourage the development of standards/land use arrangements which when constructed provide aesthetically pleasing, human scale, and "walkable" streetscapes.

\section{Caltrans' Highway Design Manual - Chapter 100}

109.1- Basic Precept - On any highway, pleasing appearance is an important consideration...and is particularly true of the many portions of the State Highway System situated in areas of natural beauty." A higher standard for aesthetics must be considered for projects on a state scenic highway.

109.2- Design Speed - The design speed should be carefully chosen as it is the key element, which establishes standards for the horizontal alignment and profile of the highway. These requirements in turn directly influence how well the highway blends into the landscape. Scenic values, particularly in areas of natural scenic beauty must play a part along with the other factors set forth under index 101.0 in selecting a design speed.

\section{3 - Aesthetic Factors}

Throughout the planning and design consider the following:

a) The location of the highway should be such that the new construction will preserve the natural environment and will lead to and unfold scenic positions.

b) The general alignment and profile of the highway should fit the character of the area traversed so that unsightly scars of excavation and embankment will be held to a minimum. Curvilinear horizontal alignment should be coordinated with vertical curvature to achieve a pleasing appearance.

c) Destruction of desirable vegetation should be minimized.

d) Appropriate replacement planting should be provided when specimens removed are considered significant. When native or specimen trees are removed, replacement plantings should reflect the visual importance of the plantings lost. Where the visual impact of tree removal is substantial, replacement with large transplants or specimen size trees may be appropriate. If not, an appropriate number of smaller replacements may be required to ensure eventual survival of an adequate number of plants. Provisions for watering and establishment planting should also be considered. The District Landscape Architect should be consulted early in the planning and design process so that the appropriate conservation and revegetation measures are incorporated.

e) Existing vegetation such as trees or large brush may be selectively thinned or removed to open up scenic vistas or provide a natural looking boundary between forest and cleared areas. Vegetation removals for aesthetic purposes should be undertaken only with the concurrence of the District Landscape Architect.

f) Vista Points should be provided when views and scenery of outstanding merit occur and feasible sites can be found.

g) Whenever feasible, wide medians and independent roadways should be provided on multilane facilities as these features add scenic interest and relieve the monotony of parallel roadways.

h) Bridges, tunnels, and walls merit consideration in lieu of prominent excavation and embankment slopes when costs of such alternatives are not excessive. 
i) Slopes should be flattened whenever practical and vegetation provided so that lines of construction are softened.

i) Structures should be located and designed to give the most pleasing appearance.

k) Scars from material sites should be avoided. Planting compatible with surroundings should be undertaken to relegate such scars when they are unavoidable.

I) Drainage appurtenances should be so located that erosion, sumps, and debris collection areas are hidden from view or eliminated when site conditions permit.

m) Interchange areas should be graded to provide graceful, natural looking contours. Appearance can be further enhanced by planting a vegetative cover approximate to the locality, being careful to maintain driver visibility.

n) In location where graffiti has been excessive, designs that deter graffiti should be used. 


\section{Framework for Protection of Historic Resources}

\section{California Environmental Quality Act (CEQA) 15300.2. Exceptions}

(d) Scenic Highways - A categorical exemption shall not be used for a project which may result in damage to scenic resources, including but not limited to, trees, historic buildings, rock outcroppings, or similar resources, within a highway officially designated as a state scenic highway. This does not apply to improvements which are required as mitigation by an adopted negative declaration or certified EIR.

( $f$ Historical Resources - A categorical exemption shall not be used for a project which may cause a substantial adverse change in the significance of a historical resource.

\subsection{Consideration and Discussion of Significant Environmental Impacts.}

(a) The Significant Environmental Effects of the Proposed Project - An EIR shall identify and focus on the significant environmental effects of the proposed project. In assessing the impact of a proposed project on the environment, the lead agency should normally limit its examination to changes in the existing physical conditions in the affected area as they exist at the time the notice of preparation is published, or where no notice of preparation is published, at the time environmental analysis is commenced. Direct and indirect significant effects of the project on the environment shall be clearly identified and described, giving due consideration to both the short-term and long-term effects. The discussion should include relevant specifics of the area, the resources involved, physical changes, alterations to ecological systems, and changes induced in population distribution, population concentration, the human use of the land (including commercial and residential development), health and safety problems caused by the physical changes, and other aspects of the resource base such as water, historical resources, scenic quality, and public services. The EIR shall also analyze any significant environmental effects the project might cause by bringing development and people into the area affected. For example, an EIR on a subdivision astride an active fault line should identify as a significant effect the seismic hazard to future occupants of the subdivision. The subdivision would have the effect of attracting people to the location and exposing them to the hazards found there.

(b) Significant Environmental Effects Which Cannot be Avoided - if the Proposed Project is Implemented. Describe any significant impacts, including those which can be mitigated but not reduced to a level of insignificance. Where there are impacts that cannot be alleviated without imposing an alternative design, their implications and the reasons why the project is being proposed, notwithstanding their effect, should be described.

(5) If the lead agency determines that a mitigation measure cannot be legally imposed, the measure need not be proposed or analyzed. Instead, the EIR may simply reference that fact and briefly explain the reasons underlying the lead agency's determination.

b) Mitigation Measures Related to Impacts on Historical Resources.

(1) Where maintenance, repair, stabilization, rehabilitation, restoration, preservation, conservation or reconstruction of the historical resource will be conducted in a manner consistent with the Secretary of the Interior's Standards for the Treatment of Historic Properties with Guidelines for Preserving, Rehabilitating, Restoring, and Reconstructing Historic Buildings (1995), Weeks and Grimmer, the project's impact on the historical resource shall generally be considered mitigated below a level of significance and thus is not significant.

(2) In some circumstances, documentation of an historical resource, by way of historic narrative, photographs or architectural drawings, as mitigation for the effects of demolition of the resource will not mitigate the effects to a point where clearly no significant effect on the environment would occur. 
(3) Public agencies should, whenever feasible, seek to avoid damaging effects on any historical resource of an archaeological nature. The following factors shall be considered and discussed in an EIR for a project involving such an archaeological site:

A) Preservation in place is the preferred manner of mitigating impacts to archaeological sites. Preservation in place maintains the relationship between artifacts and the archaeological context. Preservation may also avoid conflict with religious or cultural values of groups associated with the site.

(B) Preservation in place may be accomplished by, but is not limited to, the following:

1. Planning construction to avoid archaeological sites;

2. Incorporation of sites within parks, greenspace, or other open space;

3. Covering the archaeological sites with a layer of chemically stable soil before building tennis courts, parking lots, or similar facilities on the site.

4. Deeding the site into a permanent conservation easement.

(C) When data recovery through excavation is the only feasible mitigation, a data recovery plan, which makes provision for adequately recovering the scientifically consequential information from and about the historical resource, shall be prepared and adopted prior to any excavation being undertaken. Such studies shall be deposited with the California Historical Resources Regional Information Center. Archaeological sites known to contain human remains shall be treated in accordance with the provisions of Section 7050.5 Health and Safety Code.

(D) Data recovery shall not be required for an historical resource if the lead agency determines that testing or studies already completed have adequately recovered the scientifically consequential information from and about the archaeological or historical resource, provided that the determination is documented in the EIR and that the studies are deposited with the California Historical Resources Regional Information Center.

\section{Framework for Protection of Natural Resources}

(See Appendix C for complete San Luis Obispo County Coastal Plan Policies Section 6 - Environmentally Sensitive Habitats)

\section{San Luis Obispo County Coastal Plan Policies}

Policy 1: Land Uses Within or Adjacent to Environmentally Sensitive Habitats - New development within or adjacent to environmentally sensitive habitats shall not significantly disrupt the resource. Within the existing resource, only those uses dependent on such resources shall be allowed within the area.

Policy 3: Habitat Restoration - The County or Coastal Commission should require the restoration of damaged habitats as a condition of approval when feasible. 
Policy 4 (b) Wetlands - Coastal wetlands are recognized as environmentally sensitive habitat areas. The natural ecological functioning and productivity of wetlands and estuaries shall be protected, preserved and where feasible, restored.

Policy 18: Coastal Streams and Riparian Vegetation - Coastal Streams and adjoining riparian vegetation are environmentally sensitive habitat areas and natural hydrological system and ecological function of the coastal streams shall be protected and preserved.

Policy 19: Development in or Adjacent to a Coastal Stream - Development adjacent to or within the watershed (that portion within the coastal zone) shall be sited and designed to prevent impacts which would significantly degrade the coastal habitat and shall be compatible with the continuance of such habitat areas. This shall include evaluation of erosion and runoff concerns.

Policy 27: Protection of Terrestrial Habitats - Designated plant and wildlife habitats are environmentally sensitive habitat areas and emphasis for protection should be placed on the entire ecological community. Only uses dependent on the resource shall be permitted within the identified sensitive habitat portion of the site.

Policy 29: Design of Trails in and Adjoining Sensitive Habitats - San Luis Obispo County, or the appropriate public agency, shall ensure the design of trails in and adjoining sensitive habitat areas shall minimize adverse impacts on these areas.

Policy 36: Protection of Kelp Beds, Offshore Rocks, Rocky Points, Reefs and Intertidal Areas - Uses shall be restricted to recreation, education and commercial fishing. Adjacent development shall be sited and designed to mitigate impacts that would be incompatible with the continuance of such habitat areas.

\section{City of Morro Bay General Plan}

Program S-6.2 Cut and fill operations shall be minimized.

Program S-6.3 Development shall be designed to fit the site topography, soils, geology, hydrology, and other existing conditions and be oriented so that grading and other site preparation is kept to an absolute minimum.

Program S-7.1 Permitted grading operations on hillsides, the smallest practical areas of land shall be exposed at any one time during development, and the length of exposure shall be kept to the shortest practicable amount of time. Local Coastal Program Land Use Policies 9.05, 9.06, and 9.07 mirror the General Plan programs.

\section{Regional - Regional Transportation Plan (RTP) Policies}

- OBJ3: ENVIRONMENTAL ENHANCEMENT AND PROTECTION - Establish, maintain, and improve transportation systems in a manner that avoids or minimizes significant negative impacts to the environment. (Ongoing) 
- 3c - Encourage local jurisdictions and Caltrans to restrict street, road and highway improvements, where practical, within existing rights of way. Major widenings, such as additional lanes on Route 101, should be considered in the median strip, using retaining walls, cribwalls and nonstandard features (lanes, shoulders, medians, and ramps) where right-of-way is highly restricted (i.e. The Cuesta Grade, Monterey Street to Marsh Street in San Luis Obispo),

- $3 f$ - Encourage local jurisdictions and Caltrans to preserve high quality visual resources and minimize adverse impacts to land forms, geology and soils to the maximum extent possible when constructing new routes or expanding existing routes, and mitigate projects by proper design and planning including: avoiding construction on slopes in excess of $30 \%$; centerline realignments and modified standards to minimize grading and preserve unique important features and vistas; landscape and revegetation plans using natural vegetation; and use of contour grading to blend cuts/fills with the adjacent topography.

\section{California Environmental Quality Act (CEQA)}

National Environmental Policy Act (NEPA)

Endangered Species Act (ESA) 


\section{APPENDIX C}

County of San Luis Obispo Scenic Highway Corridor Protection Plan 


\title{
SCENIC HIGHWAY CORRIDOR PROTECTION PLAN
}

\author{
For California State Highway One, San Luis Obispo County
}

On November 20, 1998, the Departmental Transportation Advisory Committee (DTAC) voted unanimously to approve the County of San Luis Obispo's Resolution Package, submitted as part of the process for obtaining State Scenic Highway designation for Highway One from the San Luis Obispo City limits to the Monterey County Line.

In order to proceed with the designation process, the County is now submitting a Corridor Protection Plan, consisting entirely of currently existing county-wide and coastal zone land-use ordinances, as well as existing land use ordinances and policies within the city limits of Morro Bay. The five areas addressed in this protection plan, as required by Caltrans' Guidelines for the Official Designation of Scenic Highways are:

Regulation of Land Use (density and allowable land uses) Site Planning (review authority for proposed developments) Prohibition of off-site outdoor advertising, and control of on-site advertising Control of earthmoving and landscaping (grading ordinances, landscaping requirements) Design and appearance of structures and equipment (utility structures, etc.)

In 1972, the voters passed Proposition 20, known as the Coastal Initiative, which established the California Coastal Act. Among other things, the Coastal Act designated a "Coastal Zone," along the coastal fringe from Oregon to Mexico. The Coastal Zone is subject to more stringent guidelines having to do with development patterns and visual resources.

As a result of the Coastal Act, local jurisdictions were required to prepare Local Coastal Plans (LCPs) containing a Coastal Zone Land Use Ordinance (CZLUO) to incorporate state mandated coastal protections, into local General Plans. Once a local jurisdiction's LCP is certified by the Commission, it is deemed to be in compliance with these stricter guidelines. Following certification, local jurisdictions assume permitting authority from the Commission. However, most building permits issued by the County or the City within the Coastal Zone is appealable to the Commission.

Both the County of San Luis Obispo and the City of Morro Bay have certified Local Coastal Plans. This means their zoning and allowable land use ordinances have been deemed to be in compliance with the spirit and the letter of the Coastal Act. The section of Highway One proposed for Scenic Highway designation is therefore protected by the most stringent land use requirements in the state. (See Attachment A 1-4)

\section{COUNTY OF SAN LUIS OBISPO}

\section{-Regulation of Land Use (density and allowable land uses)}

Approximately 99 percent of the land within the scenic corridor is zoned Agricultural. Within the County, the minimum parcel size is 320 acres, with one residence allowable per parcel. Special circumstances such as irrigated orchards or vineyards may qualify for a 20 acre minimum parcel size. Allowable uses on $\mathrm{Ag}$ land are outlined in the Coastal Zone Framework for Planning Table "0." They include, Crop Production and Grazing, Ag processing, Ag Accessory Structures, Nurseries, Specialized Animal Facilities, Coastal Access ways, Passive Recreation, Farm Support Quarters, Home Occupations, Bed \& Breakfasts, Single 
Family Dwellings, Temporary Dwellings, Game Preserves, Water Wells and Impoundments, Forestry and Accessory Equipment Storage.

A small portion of the route is zoned Rural Lands. The minimum parcel size for Rural Lands is also 320 acres, but two residences are allowed per parcel, and special circumstances can allow parcels of 10 acres in size. Allowable uses on Rural Lands include all allowable uses under Ag zoning, plus the addition of a single Caretaker's Residence per parcel.

Land along the scenic corridor within the Urban Service Lines of San Simeon, Cambria and Cayucos, and the City Limits of Morro Bay, is variously zoned Residential Single Family, Residential Multi-family, Commercial Retail, Commercial Service, Commercial Retail and Public Facilities.

Because many different types of zoning are frequently found in a relatively small area, and because virtually all of the communities have some combination of all types of zoning (with the exception of San Simeon Acres and Cayucos, which have no Public Facilities zoning visible from the highway), it makes sense to consider the allowable uses in all of these categories together.

Single family dwellings, temporary dwellings, apartment houses, condominiums, mobile homes, mobile home parks, retail businesses, service stations, restaurants, consumer repair services, health care services, hotels, motels, bed \& breakfasts, and warehouses are the most common uses permitted.

Less than one percent of the route is zoned Open Space or Recreational. The only allowable uses of Open Space are utility lines, game preserves, water impoundments, coastal access ways, passive recreation Crop production, grazing, and mines (any mine proposal would-be subject to the highest level of review, a Development Permit, and would require an environmental impact report be prepared). Recreational zoning may support crops and grazing, coastal access, libraries, marinas, drive-in theaters, outdoor sports and recreation, passive recreation, camping, forestry operations, and single family dwellings. Other uses are allowable in all land use categories if special conditions are met. See Attachment B, Table "N" from the CZ Framework For Planning for a complete listing.

\section{-Site Planning (review authority for proposed developments)}

The review process for approving new development in the Coastal Zone is as follows:

1) Minor Use Permits (MUPs) are issued directly from the County Planning and Building Department. Before issuance, County Planning staff evaluates the proposed project for compliance with local zoning and building ordinances. If a project application is deemed complete and in compliance, the MUP is publicly noticed in the newspaper. If no member of the public requests a hearing, the MUP is issued to the applicant. If a member of the public does request a hearing, a hearing is scheduled before a hearing office. If the decision of the hearing officer is appealed, the Planning Commission will review the MUP. If the decision of the Planning Commission is appealed, the Board of Supervisors will consider the project. If the project is in the Coastal Appealable zone, the Board's decision may be appealed to the Coastal Commission. Single-family residences, certain types of fences, and remodels are typical developments which qualify for a MUP.

2) Development Plans are required by the Planning Department for more complex or larger projects. These require the applicant to produce an Environmental Impact Report (EIR) that documents all the changes, which will take place as a result of development. Mitigations to those impacts are also detailed in an EIR. Development Plans and their accompanying EIRs are considered by the Planning Commission in fully noticed public hearings. The Planning Commission reviews the project's compliance with General 
Plan policy, local Advisory Council input, and compliance with the LCP. If either the applicant or a member of the public does not appeal the decision of the Planning Commission, a permit will be issued. If the decision is appealed to the Board of Supervisors, the Board considers it in a fully noticed public hearing. The Board's decision is appealable to the Coastal Commission if the project is within the appealable zone.

3) General Plan Amendments and Area Plan Updates require comprehensive EIRs, fully noticed public hearings, and must be approved by the Board of Supervisors. Updates and amendments require Coastal Commission certification before taking effect.

4) The California Coastal Commission is the final permitting authority in the Coastal Zone. The Commission, made up of 12 members appointed by the Governor, the Speaker of the Assembly and the President Pro Tern of the Senate, reviews the project for compliance with- the Coastal Act. Section 30251 of the Coastal Act states: "The scenic and visual qualities of the coastal areas shall be considered and protected as a resource of public importance. Permitted development shall be sited and designed to protect views to and along the ocean and scenic coastal areas, to minimize the alteration of natural land forms, to be visually compatible with the character of surrounding areas, and, where feasible, to restore and enhance the visual quality in visually degraded areas. New development in highly scenic areas such as those designated in the California Coastline Preservation and Recreation Plan prepared by the Department of Parks and Recreation and by local government shall be subordinate to the character of its setting."

\section{-Prohibition of off-site outdoor advertising, and control of on-site advertising}

The County of San Luis Obispo has a county-wide moratorium on off-site billboard advertising. In section 23.04.306 (c), the CZLUO cites County Ordinances 2715 and 2740 as prohibiting:

"Any off-premise sign that directs attention to a business, service, product, or entertainment not sold or offered on the premises on which the sign is located, including but not limited to billboards and other off-premise outdoor advertising signs."

On-site advertising within the Coastal Zone is limited as well. No lighted (including neon) or flashing signs are permitted. Commercial signs are limited in dimension to no more that $15 \%$ of the building face, up to a maximum of 80 square feet. Marquee signs have a maximum area of 40 square feet. Maximum height for freeway identification signs is 50 feet above grade. A copy of CZLUO section 23.04.3 10 is attached (See attachment C I - 10).

\section{-Control of earthmoving and landscaping (grading ordinances, landscaping requirements)}

Any grading in the Coastal Zone which takes place on slopes greater than $10 \%$ and/or moves more than 5,000 cubic yards of earth requires a grading permit. All grading permit applications are reviewed by the Environmental Coordinator for a determination pursuant to CEQA (California Environmental Quality Act). The Environmental Coordinator makes the determination whether the project warrants a negative declaration or an EIR. This determination is returned in writing to the Planning Department. CZLUO section 23.05.030 (e.3) states one of the four conditions of approval is that "The proposed grading will not create substantial adverse long-term effects visible from off-site". The County's Grading Standards in the Coastal Zone further limit grading for new development to slopes no greater than $30 \%$, and state that grading shall not occur within 100 feet of any environmentally sensitive habitat. Special attention is given to public view corridors in section 23.05.034, which states: 
"Grading, vegetation removal and other land form alterations shall be minimized on sites located within areas determined by the Planning Director to be a public view corridor from

collector or arterial roads. Where feasible, contours of finished grading are to blend with adjacent natural terrain to achieve consistent grade and appearance."

A complete copy of this section of the CZLUO is attached (See Attachment C I I - 18).

\section{-Design and appearance of structures and equipment (utility structures, etc.)}

In section 23.08.286 of the CZLUO, development standards of electric transmission lines are discussed. Sub-section d.(4) states:

"Where feasible, utility lines shall be undergrounded when their placement would limit or detract from views of the ocean from collector or arterial roads. In all other cases, they shall be sited to minimize their visibility from public roads."

Public Utility Structures for other than electric and communications transmission and natural gas distribution require a Development Plan. Unless the Environmental Coordinator determines the project is exempt, this triggers the need for an Environmental Impact Report which must be certified by the Planning Commission or, on appeal, the Board of Supervisors. Pursuant to CZLUO section 23.08.288, the permit application shall include, among other things, a proposed design of the facility, revegetation, screening and landscaping during construction. Once constructed, Public Utility Facilities shall:

"...be screened on all sides. An effective barrier will be established through the use of a solid wall, fencing and/or landscaping. The adequacy of the proposed screening will be determined during the land use permitting process."

A copy of the complete section in attached. (See Attachment C 19-2 1). 


\section{APPENDIX D}

San Luis Obispo County Coastal Plan Policies, Environmentally Sensitive Habitats 


\section{CHAPTER 6: ENVIRONMENTALLY SENSITIVE HABITATS}

\section{INTRODUCTION}

A basic goal of the California Coastal Act of 1976 is to "protect, maintain, and where feasible, enhance and restore the overall quality of the coastal zone environment and its natural and man-made resources." To achieve this goal, the Local Coastal Program identifies and protects sensitive habitat areas through the designation of appropriate land uses and management techniques. Environmentally sensitive habitats are defined by the Coastal Act as "any area in which plant or animal life or their habitats are either rare or especially valuable because of their nature or role in an ecosystem and which could be easily disturbed or degraded by human activities and developments."

\section{Relationship to Coastal Act Policies}

The following are Coastal Act Policies which address the issues of environmental protection.

30230. Marine resources shall be maintained, enhanced, and where feasible, restored. Special protection shall be given to areas and species of special biological or economic significance. Uses of the marine environment shall be carried out in a manner that will sustain the biological productivity of coastal waters and that will maintain healthy populations of all species of marine organisms adequate for long-term commercial, recreation, scientific, and educational purposes.

30231. The biological productivity and the quality of coastal waters, streams, wetlands, estuaries, and lakes appropriate to maintain optimum populations of marine organisms and for the protection of human health shall be maintained, and where feasible, restored through, among other means, minimizing adverse effects of wastewater discharges and entrainment, controlling runoff, preventing depletion of groundwater supplies and substantial interference with surface waterflow, encouraging wastewater reclamation, maintaining natural vegetation buffer areas that protect riparian habitats, and minimizing alteration of natural streams.

30233. (Portion) (a) The diking, filling, or dredging of open coastal waters, wetlands, estuaries, and lakes shall be permitted in accordance with other applicable provisions of this division, where there is no feasible less environmentally damaging alternative, and where feasible mitigation measures have been provided to minimize adverse environmental effects, and shall be limited to the following: 
(1) New or expanded port, energy, and coastal-dependent industrial facilities, including commercial fishing facilities.

(2) Maintaining existing, or restoring previously dredged, depths in existing navigational channels, turning basins, vessel berthing and mooring areas, and boat launching ramps.

(3) In wetland areas only, entrance channels for new or expanded boating facilities; and in a degraded wetland, identified by the Department of Fish and Game pursuant to subdivision (b) of Section 30411, for boating facilities if, in conjunction with such boating facilities, a substantial portion of the degraded wetland is restored and maintained as a biologically productive wetland; provided, however, that in no event shall the size of the wetland area used for such boating facility, including berthing space, turning basins, necessary navigation channels, and any necessary support service facilities, be greater than 25 percent of the total wetland area to be restored.

(4) In open coastal waters, other than wetlands, including streams, estuaries, and lakes, new or expanded boating facilities and the placement of structural pilings for public recreation piers that provide public access and recreational opportunities.

(5) Incidental public service purposes, including, but not limited to, burying cables and pipes or inspection of piers and maintenance of existing intake and outfall lines.

(6) Mineral extraction, including sand for restoring beaches, except in environmentally sensitive areas.

(7) Restoration purposes.

(8) Nature study, aquaculture, or similar resource-dependent activities.

(b) Dredging and spoils disposal shall be planned and carried out to avoid significant disruption to marine and wildlife habitats and water circulation. Dredge spoils suitable for beach replenishment should be transported for such purposes to appropriate beaches or into suitable longshore current systems.

(c) In addition to the other provisions of this section, diking, filling, or dredging in existing estuaries and wetlands shall maintain or enhance the functional capacity of the wetland or estuary. Any alteration of coastal wetlands identified by the Department of Fish and Game, including, but not limited to, the 19 coastal wetlands identified in its report entitled, "Acquisition Priorities for the Coastal Wetlands of California," shall be limited to very minor incidental public facilities, restorative 
measures, nature study, commercial fishing facilities in Bodega Bay, and development in already developed parts of south San Diego Bay, if otherwise in accordance with this division...

30235. Revetments, breakwaters, groins, harbor channels, seawalls, cliff retaining walls, and other such constructions that alters natural shoreline processes shall be permitted when required to serve coastal-dependent uses or to protect existing structures or public beaches in danger from erosion and when designed to eliminate or mitigate adverse impacts on local shoreline sand supply. Existing marine structures causing water stagnation contributing to pollution problems and fish-kills should be phased out or upgraded where feasible.

30236. Channelizations, dams, or other substantial alterations of rivers and streams shall incorporate the best mitigation measures feasible, and be limited to (1) necessary water supply projects, (2) flood control projects where no other method for protecting existing structures in the flood plain is feasible and where such protection is necessary for public safety or to protect existing development, or (3) developments where the primary function is the improvement of fish and wildlife habitat.

30240. (a) Environmentally sensitive habitat areas shall be protected against any significant disruption of habitat values, and only uses dependent on such resources shall be allowed within such areas.

(b) Development in areas adjacent to environmentally sensitive habitat areas and parks and recreation areas shall be sited and designed to prevent impacts which would significantly degrade such areas, and shall be compatible with the continuance of such habitat areas. 
30411. (b) The Department of Fish and Game, in consultation with the Commission and the Department of Navigation and Ocean Development, may study degraded wetlands and identify those which can most feasibly be restored in conjunction with development of a boating facility.... Any such study shall include consideration of all the following:

(1) Whether the wetland is so severely degraded and its natural processes so substantially impaired that it is not capable of recovering and maintaining a high level of biological productivity without major restoration activities.

(2) Whether a substantial portion of the degraded wetland, but in no event less than 75 percent, can be restored and maintained as a highly productive wetland in conjunction with a boating facilities project.

(3) Whether restoration of the wetland's natural values, including its biological productivity and wildlife habitat features, can most feasibly be achieved and maintained in conjunction with a boating facility or whether there are other feasible ways to achieve such values.

30607.1. Where any dike and fill development is permitted in wet- lands in conformity with this division, mitigation measures shall include, at a minimum, either acquisition of equivalent areas of equal or greater biological productivity or opening up equivalent areas to tidal action; provided, however, that if no appropriate restoration site is available, an in-lieu fee sufficient to provide an area of equivalent productive value or surface areas shall be dedicated to an appropriate public agency, or such replacement site shall be purchased before the dike or fill development may proceed. Such mitigation measures shall not be required for temporary or short-term fill or diking; provided that a bond or other evidence of financial responsibility is provided to assure that restoration will be accomplished in the shortest feasible time.

30108.2. "Fill" - means earth or other substance or material, including piling placed for the purpose of erecting structures thereon, placed in a submerged area.

\section{Background Report}

Environmentally sensitive habitat areas found within the county's coastal zone are identified in the background report, Natural Resource Areas. The report summarizes information on the natural resources of the coastal zone, including information on present conditions, sensitivity to disturbance, current impacts, land use and zoning. These habitat areas are identified according to the following categories: unique plant habitats; rare and endangered animal habitats; wetlands; coastal streams; rocky points; intertidal areas; and kelp beds. The value of each habitat is discussed, as well as possible protection techniques. A summary chart indicating the habitat type by area, prior zoning, ownership, current use, and other designations (i.e., National Landmark) follows. Marine resources 
are not as easily identified. The background report may be consulted for detailed information, though no specified recommendations are made. The purpose of the Local Coastal Plan is to recommend policies and standards that will ensure protection of these designated environmentally sensitive habitat areas.

\section{Issues and Concerns}

Issues related to specific habitat areas were identified in the back- ground report. For many of the habitat areas, common issues arise. These include concern for the following:

Type of Ownership. The acquisition of land by a public agency or the dedication of property by an individual may be the most direct way of land preservation. Where a public ownership may be desirable to allow for the appropriate level of public access that is consistent with habitat preservation. Public ownership can also provide for long-term assurance against private development on the property. Direct acquisition of fee title may not be necessary to provide for Reserved for Figure 3 here habitat protection. A "less-than-fee" interest (often called easements) may be purchased or dedicated at the time of development. The easement may permit public access or it may restrict more use or development of the property. However, where an environmentally sensitive habitat is located on a private holding, it is sometimes more desirable to maintain the private ownership status. The advantage of private ownership is that the property owner can restrict public access to the habitat to ensure adequate protection of the habitat values. The property owner may also provide a more thorough level of management and control than a public agency with limited management capability.

Development Standards. Development standards in the county Land Use Element and Coastal Zone Land Use Ordinance are mandatory requirements for new development. The standards must be satisfied to enable a permit to be approved. The Local Coastal Plan proposes standards for new development that provides for the protection of all habitat areas. Such standards include measures to control the location of structures, grading, setbacks and intensity of use. The level of review also provides for protection to the habitat. For instance, the requirements for site plan review include submittal of grading and drainage plans, and a survey of the extent of the habitat area. This additional information can ensure property siting to protect identified habitat values. 


\begin{tabular}{|c|c|c|c|c|c|}
\hline $\begin{array}{l}\text { HABITAT } \\
\text { TYPE }\end{array}$ & AREA & $\begin{array}{l}\text { CURRENT } \\
\text { ZONING }\end{array}$ & OWNERSHIP & $\begin{array}{c}\text { CURRENT } \\
\text { USE }\end{array}$ & $\begin{array}{c}\text { OTHER } \\
\text { DESIGNATIONS }\end{array}$ \\
\hline \multirow[t]{12}{*}{ PLANT COMMUNITY } & Nipomo Dunes & Unclassified & Public, State, Private & $\begin{array}{l}\text { Recreation, Education, } \\
\text { Private }\end{array}$ & $\begin{array}{l}\text { Recommended for National } \\
\text { Landmark }\end{array}$ \\
\hline & Los Osos Oak Forest & Residential & State & Reasearch, Education & \\
\hline & Los Osos Bishop Pines & $\begin{array}{l}\text { Agriculture, Residential, } \\
\text { Uncl. Commercial }\end{array}$ & Private & Residential & \\
\hline & $\begin{array}{l}\text { Camp San Luis Relict } \\
\text { Grassland }\end{array}$ & Agriculture & State & Research, Education & \\
\hline & $\begin{array}{l}\text { Montana de Oro } \\
\text { Grassland }\end{array}$ & Unclassified & State & Recreation & \\
\hline & Black Hill & State & State & Research & \\
\hline & Coon Creek & $\begin{array}{l}\text { Unclassified } \\
\text { State }\end{array}$ & State & Education, Recreation & \\
\hline & Hazard Canyon & Unclassified & State & Recreation, Education & \\
\hline & Morro Bay Sandspit & Unclassified & State & Recreation, Education & \\
\hline & Arroyo de la Cruz & $\begin{array}{l}\text { Agriculture } \\
\text { Unclassified }\end{array}$ & Private & Agriculture & $\begin{array}{l}\text { Recommended for National } \\
\text { Landmark }\end{array}$ \\
\hline & Piedras Blancas Dunes & Agriculture & Private, Coast Guard & $\begin{array}{l}\text { Private, Education, } \\
\text { Research }\end{array}$ & $\begin{array}{l}\text { Recommended for National } \\
\text { Landmark }\end{array}$ \\
\hline & $\begin{array}{l}\text { Cambria - Monterey Pine } \\
\text { Forest }\end{array}$ & $\begin{array}{l}\text { Unclassified } \\
\text { Agriculture }\end{array}$ & Private & Private & \\
\hline \multirow{4}{*}{$\begin{array}{l}\text { RARE AND } \\
\text { ENDANGERED } \\
\text { WILDLIFE RANGE }\end{array}$} & Morro Bay Kangaroo Rat & $\begin{array}{l}\text { Residential } \\
\text { Unclassified }\end{array}$ & Private, State & $\begin{array}{l}\text { Redsidential } \\
\text { Open Space }\end{array}$ & \\
\hline & $\begin{array}{l}\text { American Peregrine } \\
\text { Falcon }\end{array}$ & & State & Ecological Reserve & \\
\hline & California Sea Otter & $\begin{array}{l}\text { Commercial } \\
\text { Residential }\end{array}$ & Private & $\begin{array}{l}\text { Commercial } \\
\text { Residential }\end{array}$ & \\
\hline & Fairbanks Property & State & State & Education & \\
\hline COASTAL STREAMS & (See text discussions) & & & & \\
\hline \multirow[t]{10}{*}{ COASTAL } & Santa Maria River Mouth & Unclassified & Private & Study Area & 208 Proposed Study Area \\
\hline & Oso Flaco Lakes & Unclassified & State & Recreation & Marked \\
\hline & Dunes Lake & Unclassified & Private & Recreation & \\
\hline & Oceano Lagoon & & State & Feeding Stop & \\
\hline & Pismo Marsh & & State & Education & Ecological Reserve \\
\hline & Morro Bay & & State, City, Private & Recreation, Research & \\
\hline & Eto \& Warden Lakes & Agriculture & Private & Agriculture & \\
\hline & $\begin{array}{l}\text { Sweet Springs/Cuesta-by- } \\
\text { the-Sea }\end{array}$ & & Private & Feeding \& Resting & $\begin{array}{l}\text { Proposed Acquistion by Dept. } \\
\text { of Fish \& Game }\end{array}$ \\
\hline & Los Osos Estuary & & State & Education & \\
\hline & San Simeon Lagoon & & State & Feeding \& Nesting & \\
\hline
\end{tabular}

Figure 6-1: Sensitive Habitat Areas 
Erosion Control. Uncontrolled erosion through natural or development activities can threaten the stability of an environmentally sensitive area. Specific recommendations for erosion control are discussed in the Watershed chapter.

Other habitat types pose individualized needs and demand special management strategies. Coastal streams that serve as anadromous fish habitats are susceptible to impacts from surrounding properties. In-stream alterations, riparian vegetation removal, water diversions and pollution contribute to the need to protect streams that provide fish and other habitat values.

A second unique concern is the impact of off-road vehicles on habitat areas. Uncontrolled ORV use of bayfront areas and the coastal dunes can damage the habitat of a variety of species. Where this access is appropriate, it must be provided at a level which is consistent with the carrying-capacity of the area.

The recommendations of the Local Coastal Program address these concerns by ensuring protection of environmentally sensitive habitat areas, by establishing programs, policies, standards and ordinances.

\section{POLICIES FOR ENVIRONMENTALLY SENSITIVE HABITATS}

\section{A. SENSITIVE HABITATS}

Environmentally sensitive habitat areas are settings in which plant or animal life (or their habitats) are rare or especially valuable due to their special role in an ecosystem. Designation of environmentally sensitive habitats include but are not limited to: 1) wetlands and marshes;2) coastal streams and adjacent riparian areas; 3 ) habitats containing or supporting rare and endangered or threatened species; 4) marine habitats containing breeding and/or nesting sites and coastal areas used by migratory and permanent birds for resting and feeding. The Coastal Act provides protection for these areas and permits only resource-dependent uses within the habitat area. Development adjacent must be sited to avoid impacts. While each of these habitat types is discussed in greater detail, general policies for protection of habitats are as follows:

\section{Policy 1: Land Uses Within or Adjacent to Environmentally Sensitive Habitats}

New development within or adjacent to locations of environmentally sensitive habitats (within 100 feet unless sites further removed would significantly disrupt the habitat) shall not significantly disrupt the resource. Within an existing resource, only those uses dependent on such resources shall be allowed within the area. [THIS POLICY SHALL BE IMPLEMENTED PURSUANT TO SECTIONS 23.07.170-178 OF THE COASTAL ZONE LAND USE ORDINANCE (CZLUO).] 


\section{Policy 2: $\quad$ Permit Requirement}

As a condition of permit approval, the applicant is required to demonstrate that there will be no significant impact on sensitive habitats and that proposed development or activities will be consistent with the biological continuance of the habitat. This shall include an evaluation of the site prepared by a qualified professional which provides: a) the maximum feasible mitigation measures (where appropriate), and $b$ ) a program for monitoring and evaluating the effectiveness of mitigation measures where appropriate. [THIS POLICY SHALL BE IMPLEMENTED PURSUANT TO SECTIONS 23.07.170-178 OF THE CZLUO.]

\section{Policy 3: $\quad$ Habitat Restoration}

The county or Coastal Commission should require the restoration of damaged habitats as a condition of approval when feasible. Detailed wetlands restoration criteria are discussed in Policy 11. [THIS POLICY SHALL BE IMPLEMENTED PURSUANT TO SECTION 23.07.170 OF THE CZLUO.]

\section{Policy 4: No Land Divisions in Association with Environmentally Sensitive Habitats}

No divisions of parcels having environmentally sensitive habitats within them shall be permitted unless it can be found that the buildable area(s) are entirely outside the minimum standard setback required for that habitat ( 100 feet for wetlands, 50 feet for urban streams, 100 feet for rural streams). These building areas (building envelopes) shall be recorded on the subdivision or parcel map. [THIS POLICY SHALL BE IMPLEMENTED PURSUANT TO SECTION 23.07.170 OF THE CZLUO.]

\section{B. WETLANDS}

Coastal wetlands, tidal marshes, mudflats, freshwater marshes and related bodies of water are a dynamic, fragile link between oceanic and terrestrial ecosystems. Wetlands help improve the quality and quantity of water, as well as providing important wildlife habitats. By slowing run- off water, wetland vegetation causes silt to settle out, improving water quality. By retaining water during dry periods and holding it back during floods, wetlands will keep the water table high and relatively stable. By providing nesting, breeding and feeding grounds, wetlands support the diversity as well as health of wildlife. Several rare and/or endangered species are found within local coastal wetlands, including the California Brown Pelican and the California Least Tern.

The Coastal Act identifies wetlands and estuaries as environmentally sensitive habitats and requires that the biological productivity and the quality of such areas be maintained and, where feasible, restored. The special value of wetlands and estuaries is further recognized in Section 30603 of the Act in that the Coastal Commission retains appeal authority for any development approved by the county within 100 feet of any wetland after certification of the Local Coastal Program. 
The Coastal Act defines "wetland" in Section 30121 as follows:

"Wetland" means lands within the coastal zone which may be covered periodically or permanently with shallow water and includes salt- water marshes, freshwater marshes, open or closed brackish water marshes, swamps, mudflats and fens.

To provide accurate delineation of wetlands within the coastal zone, the United States Fish and Wildlife Service and California Department of Fish and Game are conducting field surveys of wetlands within the county. These wetlands are being mapped using the following criteria established by the Fish and Wildlife Service.

"Wetland" is defined as land where the water table is at, near, or above the land surface long enough to do either of the following: a) promote the formation of (hydric) soils that are saturated with water at or near the surface and are deficient of oxygen long enough during the growing season to result in soil properties that reflect dominate wetness characteristics near the soil surface (within 10"); or b) support the growth of hydrophytic plants which grow in water or in wet habitats.

The primary wetland areas within San Luis Obispo County include: San Carpoforo Creek Lagoon, Arroyo de La Cruz Creek Lagoon, San Simeon Creek Lagoon, Santa Rosa Creek Lagoon, Pico Creek Lagoon, Morro Bay (includes Sweet Springs, Cuesta-by-the-Sea Marsh and Los Osos Estuary), Pismo Marsh, Oceano Lagoon, Dune Lakes, Oso Flaco Lake and the Santa Maria River mouth. East of these wetlands is identified as a Sensitive Resource Area and specific recommendations are included in the Land Use Element by planning area. Other small isolated wetlands exist and would need to be addressed at the time of a specific development project.

In general, the upland extent of a wetland is determined to be land that is flooded or saturated at some time during years of normal precipitation. Because of their proximity to the heavily populated coastline, coastal wetlands are especially vulnerable to disturbance. To ensure their protection, a wide range of resource management techniques will be necessary.

Fee Simple Acquisition. The most obvious method of wetland protection is through acquisition by a public agency. All coastal wetlands below the mean high tide line are historically state property and are administered by the State Lands Commission. Various pro- grams are available to provide funding for wetland acquisition. The State Department of Parks and Recreation is the county's largest public owner of wetlands. The Bagley Conservation Fund provides funds and the State Beach, Park, Recreational, and Historical Bond Act of 1974 allows for the issuance of bonds to raise funds for the State Department of Parks and Recreation to acquire wetlands. Money raised through the sale of hunting and fishing licenses as well as funds provided by the Environmental Protection and Research Act of 1970 allows the California Department of Fish and Game to acquire coastal wetlands. Under the Federal Coastal Zone Management Act of 1972, wetlands designated as Estuarine Sanctuaries may allow the State to receive matching federal funds for acquisition of the wetland. The State Coastal Conservancy was established by the State Legislature in 1977 to implement a program of resource protection including wetland preservation and restoration. 
Dedication or Easement. A much less used method of wetland preservation within this county is public easement or dedication, which in most instances involves surrender of development rights by the property owner within the wetland in return for lowered assessments. The county does not currently have complete guidelines for an Open Space Easement Program though open space easements have been granted. Usually, an easement would be granted for at least 10 or 20 years. Coastal wetlands may also be preserved from development through the Agricultural Preserve Program. This method does not require that adjoining land be eligible for inclusion under the agricultural preserve program; however, unless wetland is designated by the county (after consulting the Department of Fish and Game) as an area of great importance for protection or enhancement of state wildlife resources or to be a managed wetland, it will not qualify. A managed wetland is an area that is diked off, to which water is occasionally admitted, and for three years prior to the agricultural contract was used as a waterfowl hunting preserve, game refuge or used for agricultural purposes (Williamson Act, 41201, J \& L). Based on this, most county wetlands would not be eligible unless adjoining agriculture lands are included.

Permit Process. Development within coastal wetlands has been subject to a number of permit procedures from various state and federal agencies. Under Section 10 of the Rivers and Harbor Act of 1899, it is unlawful to build, excavate, or fill or modify any navigable water of the United States unless permitted by the Army Corps of Engineers. Under Section 404 of the Federal Water Pollution Control Act Amendments of 1972, this was expanded to cover all waters of the United States. Most coastal wetlands within this county are covered by these laws.

Section 208 of the Federal Water Pollution Control Act Amendments of 1972 controls water quality problems related to nonpoint pollution sources, primarily sedimentation. Within San Luis Obispo County, this program is administered by the California Regional Water Quality Control Board; which also controls discharge of sewage and other wastewaters into wetlands.

Sections 1601 and 1603 of the Fish and Game Code require that any party planning any significant streambed alteration reach an agreement with the Department of Fish and Game.

Watershed Control. Within the watershed of a wetland, two key natural processes are directly related to the condition of the wetland. These are the processes of erosion and runoff and will be discussed under the section entitled Coastal Watersheds. The county's major role in wetland protection, up to now, has been through the control of adjacent land uses.

The following policies are established for protection of the wetland habitat areas within the coastal zone:

\section{Policy 5: $\quad$ Protection of Environmentally Sensitive Habitats}

Coastal wetlands are recognized as environmentally sensitive habitat areas. The natural ecological functioning and productivity of wetlands and estuaries shall be protected, preserved and where feasible, restored. [THIS POLICY SHALL BE IMPLEMENTED PURSUANT TO SECTIONS 23.07.170-178 OF THE CZLUO.] 


\section{Policy 6: $\quad$ Principally Permitted Use}

Principally permitted uses in wetlands are as follows: hunting, fishing and wildlife management; education and research projects. [THIS POLICY SHALL BE IMPLEMENTED PURSUANT TO SECTIONS 23.07.170-172 OF THE CZLUO.]

\section{Policy 7: $\quad$ Public Acquisition}

The California Department of Parks and Recreation, the California Department of Fish and Game and other public and private sources should be encouraged to acquire or accept offers-to-dedicate coastal wetlands wherever possible.

Priorities for acquisition should be:

. Sweet Springs Marsh

. $\quad$ Santa Maria River mouth

. Villa Creek Lagoon

- $\quad$ Properties surrounding Morro Bay which include wetland habitat.

[THIS POLICY SHALL BE IMPLEMENTED AS A PROGRAM.]

\section{Policy 8: $\quad$ Open Space Easements and Williamson Act Contracts}

San Luis Obispo County shall continue to encourage the use of open space easements or Williamson Act contracts to ensure preservation of coastal wetlands. The county will develop guidelines to facilitate use of open space easements to include requirements for length of dedication (i.e., perpetuity or 10 years), appropriate management responsibility, etc. [THIS POLICY SHALL BE IMPLEMENTED AS A PROGRAM.]

\section{Policy 9: $\quad$ Regional Water Quality Control Board "208" Program}

California Regional Water Quality Control Board shall administer programs identified through the "208" nonpoint source studies to ensure protection of coastal wetlands and water quality. (The county has incorporated the Basin Plan Amendment requirements into the COASTAL ZONE Land Use Ordinance.) [THIS POLICY SHALL BE IMPLEMENTED AS A PROGRAM.]

\section{Policy 10: $\quad$ State Department of Fish and Game Review}

The State Department of Fish and Game shall review all applications for development in or adjacent to coastal wetlands and recommend appropriate mitigation measures where needed which should 
be incorporated in the project design. [THIS POLICY SHALL BE IMPLEMENTED PURSUANT TO SECTION 23.07.172 OF THE CZLUO.]

\section{Policy 11: $\quad$ Diking, Dredging or Filling of Wetlands}

All diking, dredging and filling activities shall conform to the provisions of Section 30233, 30411 and 30607.1 of the Coastal Act. These policies establish the appropriate uses, criteria for evaluation of a project and requirements for restoration or replacement. Allowable activities within open coastal waters, wetlands (with the exception of Morro Bay and the Santa Maria River mouth), estuaries and lakes include:

a. New or expanded port, energy, and coastal dependent industrial facilities, including commercial fishing facilities.

b. Maintenance dredging of existing, or restoring previously dredged, depths in existing navigational channels, turning basins, vessel berthing and mooring areas, and boat launching ramps.

c. In wetlands areas only, entrance channels for new or expanded boating facilities, and in a degraded wetland, identified by the Department of Fish and Game pursuant to subdivision (b) of Section 30411 for boating facilities if, in conjunction with such boating facilities, a substantial portion of the degraded wetland is restored and maintained as a biologically productive wetland; provided, however, that in no event shall the size of the wetland area used for such boating facility, including berthing space, turning basins, necessary navigational channels, and any necessary support service facilities be greater than 25 percent of the total wetland area to be restored.

d. In open coastal waters, other than wetlands, including streams, estuaries and lakes, new or expanded boating facilities.

e. Incidental public service purposes, including but not limited to, burying cables and pipes or inspection of piers and maintenance of existing intake and outfall lines.

f. Mineral extraction, including sand for restoration of beaches, except in environmentally sensitive areas.

g. Restoration purposes.

h. Nature study, aquaculture, or similar resource-dependent activities.

i. Maintenance of flood control facilities by permit. 
The wetlands of Morro Bay and the Santa Maria River mouth are identified in Section 30233(c) as among those identified by the Department of Fish and Game in its report entitled, "Acquisition Priorities for the Coastal Wetlands of California." Under this section, allowable uses within these wetlands shall be restricted and limited to very minor incidental public facilities, restorative measures consistent with PRC Section 30411 of the Coastal Act and nature study.

Diking, dredging, and filling for these types of development in wetlands, estuaries, coastal waters and lakes shall be permitted only where there is no feasible, less environmentally damaging alternative, and where feasible mitigation measures have been provided to minimize adverse environmental impacts, and where consistent with the maintenance of the tidal flow and continued biological viability of the wetland habitat. The development must meet the following conditions:

a. Diking, dredging and filling shall be prohibited in breeding and nursery areas and during periods of fish migration and spawning.

b. Diking, dredging and filling shall be limited to the smallest area feasible that is necessary to accomplish the project.

c. Designs for diking, dredging and filling and excavation projects shall include protective measures such as silt curtains, and weirs to protect water quality in adjacent areas during construction by preventing the discharge of refuse, petroleum spills and unnecessary dispersal of silt materials.

Dredge spoils shall not be deposited in areas where public access or environmental habitats would be significantly or adversely affected. Dredging and spoils disposal shall be planned and carried out to avoid significant disruption to marine and wildlife habitats and water circulation. Dredge spoils suitable for beach replenishment should be transported for such purposes to appropriate beaches or into suitable longshore currents. Limitations may be necessary on the timing of the operation, the type of operations and the quality and location of the spoils site.

Other mitigation measures are required under Section 30607.1. Where any dike fill development is permitted in wetlands in conformity with Chapter 3 of the Coastal Act, mitigation measures shall include, at a minimum, either acquisition of equivalent areas of equal or greater biological productivity or opening up equivalent areas to tidal action; provided however, that if no appropriate restoration site is available an in-lieu fee sufficient to provide an area of equivalent productive value or surface area shall be dedicated to an appropriate public agency or such replacement site shall be purchased before the dike or fill development may proceed. Such mitigation measures shall not be required for temporary or short-term fill or diking; provided that a bond or other evidence or financial responsibility is provided to assure that restoration will be accomplished in the shortest feasible time. [THIS POLICY SHALL BE IMPLEMENTED AS A STANDARD AND PURSUANT TO SECTION 23.07.172 OF THE CZLUO.]

\section{Policy 12: $\quad$ Mosquito Abatement Practices}


Mosquito abatement practices shall be limited to the minimum necessary to protect health and prevent damage to natural resources. Biological control measures are encouraged. [THIS POLICY SHALL BE IMPLEMENTED AS A STANDARD.]

\section{Policy 13: $\quad$ Vehicle Traffic in Wetlands}

No vehicle traffic shall be permitted in wetlands. This shall not restrict local and state agencies or the property owner from completing the actions necessary to accomplish a permitted use within the wetland. Pedestrian traffic shall be regulated and incidental to the permitted uses. [THIS POLICY SHALL BE IMPLEMENTED AS A STANDARD.]

\section{Policy 14: $\quad$ Adjacent Development}

Development adjacent to coastal wetlands shall be sited and designed to prevent significant impacts to wetlands through noise, sediment or other disturbances. Development shall be located as far away from the wetland as feasible, consistent with other habitat values on the site. [THIS POLICY SHALL BE IMPLEMENTED PURSUANT TO SECTION 23.07.172 OF THE CZLUO.]

\section{Policy 15: $\quad$ Wetland Buffer}

In new development, a buffer strip shall be required and maintained in natural condition along the periphery of all wetlands. This shall be a minimum of 100 feet in width measured from the upland extent of the wetland unless a more detailed requirement for a greater or lesser amount is included in the LUE or the LUO would allow for adjustment to recognize the constraints which the minimum buffer would impose upon existing subdivided lots. If a project involves substantial improvements or increased human impacts, necessitating a wide buffer area, it shall be limited to utility lines, pipelines, drainage and flood control facilities, bridges and road approaches to bridges, and roads when it can be demonstrated that: a) alternative routes are infeasible or more environmentally damaging, and b) the adverse environmental effects are mitigated to the maximum extent feasible. Access paths and/or fences necessary to protect habitats may also be permitted.

The minimum buffer strip may be adjusted by the county if the minimum setback standard would render the parcel physically unusable for the principal permitted use. To allow a reduction in the minimum standard set-back, it must be found that the development cannot be designed to provide for the standard. When such reductions are permitted, the minimum standard shall be reduced to only the point at which the principal permitted use (development), modified as much as is practical from a design standpoint, can be accommodated. At no point shall this buffer be less than 25 feet. [THIS POLICY SHALL BE IMPLEMENTED PURSUANT TO SECTION 23.07.172 OF THE CZLUO.] 


\section{Policy 16: $\quad$ Wetland Buffers Less than 100 Feet}

For buffers less than 100 feet as established consistent with Policy 15 (above) mitigation measures to ensure wetland protection shall be required, and shall include (where applicable) vegetative screening, landscaping with native vegetation, drainage controls and other such measures.

When the minimum buffer strip is adjusted by the county, it shall be done on a case-by-case basis only after the investigation of the following factors:

a. Soil type and stability of development site, including susceptibility to erosion.

b. Slope of land adjacent to the wetland and the ability to use natural topographic features to locate development.

c. Types and amount of vegetation and its value as wildlife habitat including: 1) the biological significance of the adjacent lands in maintaining the functional capacity of the wetland, and 2) the sensitivity of the species to disturbance.

d. Type and intensity of proposed uses.

e. Lot size and configuration, and the location of existing development.

[THIS POLICY SHALL BE IMPLEMENTED PURSUANT TO SECTION 23.07.172 OF THE CZLUO.]

\section{Policy 17: $\quad$ Open Space Easement for Wetlands}

Open space easements or offers to dedicate the wetland shall be a condition of major structural development (including single-family residence) for all property larger than one acre which contain wetlands habitat. [THIS POLICY SHALL BE IMPLEMENTED PURSUANT TO SECTION 23.07.172 OF THE CZLUO.]

\section{COASTAL STREAMS}

Coastal streams directly affect the coastal environment. They significantly influence flooding, natural ecosystems, sediment transport, agricultural water supply and groundwater recharge within the coastal zone. There are numerous coastal streams within San Luis Obispo County, both perennial (running year round) and ephemeral (during the rainy season only) as identified as dotted or dashed lines on USGS quadrangle maps. 
Degradation of coastal streams results from many causes, including stream channelization, water diversion and intensive land uses adjacent to and within the watershed of streams. A major concern of the Coastal Act is to prevent unnecessary stream alterations and projects which significantly increase sedimentation.

The Coastal Act identifies coastal streams as environmentally sensitive habitat areas and requires that their biological productivity and quality be protected. Stream alterations are limited to water supply projects, flood control projects when there are no other methods available for protecting existing development and projects for improvement of fish and wildlife habitat. Any alteration must employ the best mitigation measures feasible. In Section 30603, the Coastal Commission retains appeal authority after certification of the Local Coastal Plan for any development approved by the county within 100 feet of any stream.

Riparian vegetation plays an important role in the coastal stream environment, acting as a filter to remove sediment before it reaches the stream. By shading the stream, riparian vegetation keeps the water's temperature within a narrow range. This is important to many fish species, especially for steelhead trout which require a fairly constant water temperature. The interaction of the stream environment with the surrounding streamside riparian vegetation makes it necessary to provide as much protection as possible for this vegetation. The United States Fish and Wildlife Service in cooperation with the California Department of Fish and Game are currently mapping riparian vegetation within the coastal zone.

Anadromous fish are those that move from the oceans into fresh waters to reproduce. An important recreation species, the steelhead rainbow trout, have suffered a marked decline within this county. San Luis Obispo County is the southern-most area in the State where runs still occur. Since the steelhead trout has undergone marked declines and current data was inadequate to ensure proper management of the resource, a special study was undertaken to survey six coastal streams--representing a cross section of stream conditions and impacts. The study identified specific activities impinging upon the steelhead streams including modification of riparian vegetation, dewatering and impoundment, channelization and agricultural/urban developments. The loss of riparian vegetation is the consequence of channelization (Arroyo Grande Creek), urban intrusion (Santa Rosa, Arroyo Grande, and Morro Creeks) and agricultural appropriation (all streams).

Streams and creeks are sensitive areas. Development activity within and adjacent to a watercourse has profound effects on stream hydrology and water quality. To ensure protection of the coastal stream environment, a variety of resource management techniques are available. Since fee simple acquisition would not be practical, current protection is afforded by permit requirements.

Development Permits. Sections 1601 and 1603 of the California Fish and Game Code require that any party planning any significant (for private parties) streambed alteration reach an agreement with the California Department of Fish and Game. Section 5650 of the Code also makes it unlawful to place in or allow to pass into any stream any material deleterious to fish, plant life or birdlife. Under Section 404 of the Federal Water Pollution Control Act, the Army Corps of Engineers has permit control over filling in or modification of most of our coastal streams. Under Section 208 of 
this same act, the California Regional Water Quality Control Board is given permit authority over most types of discharge into coastal streams. A special study has been completed for the regional board to implement Section 208 in regard to nonpoint pollution sources. Specifically, this study identified county water bodies where sedimentation has become a problem.

Land Use. The county's major role in protection of the stream environment has been control over development of adjacent land uses and within the watershed.

The following policies provide protection for coastal stream habitats:

\section{Policy 18: $\quad$ Coastal Streams and Riparian Vegetation}

Coastal streams and adjoining riparian vegetation are environmentally sensitive habitat areas and the natural hydrological system and ecological function of coastal streams shall be protected and preserved. [THIS POLICY SHALL BE IMPLEMENTED AS A STANDARD AND PURSUANT TO SECTION 23.07.174 OF THE CZLUO.]

\section{Policy 19: Development in or Adjacent to a Coastal Stream}

Development adjacent to or within the watershed (that portion within the coastal zone) shall be sited and designed to prevent impacts which would significantly degrade the coastal habitat and shall be compatible with the continuance of such habitat areas. This shall include evaluation of erosion and runoff concerns. [THIS POLICY SHALL BE IMPLEMENTED AS A STANDARD AND PURSUANT TO SECTION 23.07.174 OF THE CZLUO.]

\section{Policy 20: $\quad$ Fish and Game Review of Streambed Alterations}

Significant streambed alterations require the issuance of a California Department of Fish and Game 1601-1603 agreement. The Department should provide guidelines on what constitutes significant streambed alterations so that the county and applicants are aware of what is considered a "significant" streambed alteration. In addition, streambed alterations may also require a permit from the U.S. Army Corp of Engineers. [THIS POLICY SHALL BE IMPLEMENTED AS A STANDARD AND PURSUANT TO SECTION 23.07.174 OF THE CZLUO.]

\section{Policy 21: County and State Review of Coastal Stream Projects}

The State Water Resources Control Board and the county shall ensure that the beneficial use of coastal stream waters is protected, for projects over which it has jurisdiction. For projects which do not fall under the review of the State Water Resources Control Board, the county (in its review of public works and stream alterations) shall ensure that the quantity and quality surface water discharge from streams and rivers shall be maintained at levels necessary to sustain the functional 
capacity of streams, wetland, estuaries and lakes. [THIS POLICY SHALL BE IMPLEMENTED AS A STANDARD AND PURSUANT TO SECTION 23.07.174 OF THE CZLUO.]

\section{Policy 22: $\quad$ Program to Control Grazing Impacts}

As recommended in the conclusions of the stream survey study, the California Department of Fish and Game may institute a pilot program on publicly owned land utilizing fencing and sediment basins to control grazing impacts on riparian vegetation and costal streams. If the project is successful, the Department of Fish and Game shall institute a voluntary program providing funds to interested local ranchers who wish to utilize this program. [THIS POLICY SHALL BE IMPLEMENTED AS A PROGRAM.]

\section{Policy 23: $\quad$ Streambed Alterations}

Channelizations, dams or other substantial alterations of rivers and streams shall be limited to: a) necessary water supply projects, b) flood control projects when there are no other feasible methods for protecting existing structures in the flood plain and where such protection is necessary for public safety or to protect existing development, and c) development where the purpose is to improve fish and wildlife habitat. All projects must employ the best feasible mitigation measures. Maintenance and flood control facilities shall require a coastal development permit. [THIS POLICY SHALL BE IMPLEMENTED PURSUANT TO SECTION 23.07.174 OF THE CZLUO.]

\section{Policy 24: $\quad$ Riparian Vegetation}

Cutting or alteration of naturally occurring vegetation that protects riparian habitat is not permitted except for permitted streambed alterations (defined in Policy 23) and where no feasible alternative exists or an issue of public safety exists. This policy does not apply to agricultural use of land where expanding vegetation is encroaching on established agricultural uses. Minor incidental public works project may also be permitted where no feasible alternative exists including but not limited to utility lines, pipelines, driveways and roads. Riparian vegetation shall not be removed to increase agricultural acreage unless it is demonstrated that no impairment of the functional capacity of the habitat will occur. Where permitted, such actions must not cause significant stream bank erosion, have a detrimental effect on water quality or quantity, or impair the wildlife habitat values of the area. This must be in accordance with the necessary permits required by Sections 1601 and 1603 of the California Fish and Game Code. [THIS POLICY SHALL BE IMPLEMENTED PURSUANT TO SECTION 23.07.174 OF THE CZLUO.]

\section{Policy 25: $\quad$ Stream Diversion Structures}


Stream diversion structures on streams appearing as dotted or dash lines on the largest scale U.S.G.S. quadrangle maps shall be sited and designed to not impede up and downstream movement of native fish or to reduce stream flows to a level which would significantly affect the biological productivity of the fish and other stream organisms. [THIS POLICY SHALL BE IMPLEMENTED PURSUANT TO SECTION 23.07.174 OF THE CZLUO.]

\section{Policy 26: $\quad$ Buffer Zone for Riparian Habitats}

In rural areas (outside the USL) a buffer setback zone of 100 feet shall be established between any new development (including new agricultural development) and the upland edge of riparian habitats. In urban areas this minimum standard shall be 50 feet except where a lesser buffer is specifically permitted. The buffer zone shall be maintained in natural condition along the periphery of all streams. Permitted uses within the buffer strip shall be limited to passive recreational, educational or existing nonstructural agricultural developments in accordance with adopted best management practices. Other uses that may be found appropriate are limited to utility lines, pipelines, drainage and flood control facilities, bridges and road approaches to bridges to cross a stream and roads when it can be demonstrated that: 1) alternative routes are infeasible or more environmentally damaging and 2) adverse environmental effects are mitigated to the maximum extent feasible. Lesser setbacks on existing parcels may be permitted if application of the minimum setback standard would render the parcel physically unusable for the principal permitted use. In allowing a reduction in the minimum setbacks, they shall be reduced only to the point at which a principal permitted use (as modified as much as is practical from a design standpoint) can be accommodated. [THIS POLICY SHALL BE IMPLEMENTED PURSUANT TO SECTION 23.07.174 OF THE CZLUO.]

\section{TERRESTRIAL ENVIRONMENTS}

Terrestrial environments within San Luis Obispo County's coastal zone include unique plant habitats and rare and endangered animal habitats. Unique plant habitats include endemics (only found in one place) plant species, endangered plant species and representative natural plant com- munities. Those species that have been identified as rare or endangered, or their habitats, are discussed.

The high ecological value of these areas is reflected by the fact that most are within public holdings. All these areas (whether in public or private holdings) are also sensitive to disturbance by man's activities. Management techniques available are:

1. Fee Simple Acquisition. Many designated areas have been acquired through this method and it is still the most desired resource management technique available.

2. Easements. As described under wetlands, there are open space easements or Williamson Act contracts available for preservation of habitat areas within this county. 
3. Development Permits. The county has established a review process for impacts to designated wildlife or vegetation habitat areas in the CZLUO. They are mapped as terrestrial habitats on the LUE combining designation maps.

Under the 1973 Endangered Species Act, the federal government will not allow federal funding for any project that will adversely impact designated species. Within the coastal zone this would specifically relate to the designated Morro Bay Kangaroo Rat habitat area located west of Pecho Road in South Bay, though it would also relate to several bird species with extensive habitat areas within the county.

The California Department of Fish and Game currently exercises control over designated critical habitat areas for rare or endangered wildlife species.

This applies to the designated Morro Bay Kangaroo Rat habitat in South Bay. The Department of Fish and Game also designates rare or endangered plant species. Since the program has just begun, there are currently no designated plant species within this county. For designated plant species, the Department of Fish and Game must be contacted concerning development that would adversely impact the plant species for development of mitigation measures. As plant species and habitat areas are recognized through this program, protection should be extended.

4. Resource Protection Zones. The Coastal Act required state agencies with property within the coastal zone to develop and recommend Resource Protection Zones (RPZs) identifying adjoining properties where development could adversely impact their holdings. For San Luis Obispo County, this specifically pertained to holdings of the State Department of Parks and Recreation and the Department of Fish and Game. Though this section of the Coastal Act was subsequently amended, the conversations between the appropriate staffs and the Local Coastal Program staff has served to bring to the county's attention the agency's concerns.

The following policies related to protection of identified terrestrial habitats within the coastal zone:

\section{Policy 27: $\quad$ Protection of Terrestrial Habitats}

Designated plant and wildlife habitats are environmentally sensitive habitat areas and emphasis for protection should be placed on the entire ecological community. Only uses dependent on the resource shall be permitted within the identified sensitive habitat portion of the site.

Development adjacent to environmentally sensitive habitat areas and holdings of the State Department of Parks and Recreation shall be sited and designed to prevent impacts that would significantly degrade such areas and shall be compatible with the continuance of such habitat areas. [THIS POLICY SHALL BE IMPLEMENTED PURSUANT TO SECTION 23.07.176 OF THE CZLUO.] 


\section{Policy 28: $\quad$ Protection of Native Vegetation}

Native trees and plant cover shall be protected wherever possible. Native plants shall be used where vegetation is removed. [THIS POLICY SHALL BE IMPLEMENTED PURSUANT TO SECTION 23.07.176 OF THE CZLUO.]

\section{Policy 29: $\quad$ Design of Trails In and Adjoining Sensitive Habitats}

San Luis Obispo County, or the appropriate public agency, shall ensure that the design of trails in and adjoining sensitive habitat areas shall minimize adverse impact on these areas. [THIS POLICY SHALL BE IMPLEMENTED AS A STANDARD.]

\section{Policy 30: $\quad$ Public Acquisition}

The California Department of Parks and Recreation, Department of Fish and Game and other public and private organizations should continue to acquire or accept offers-to-dedicate for sensitive resource areas wherever possible. [THIS POLICY SHALL BE IMPLEMENTED AS A PROGRAM.]

\section{Policy 31: $\quad$ Agriculture and Open Space Preserves}

The county should encourage the uses of Agriculture Preserves or Open Space Pre- serves to protect sensitive habitat areas where public acquisition is not feasible. [THIS POLICY SHALL BE IMPLEMENTED PURSUANT AS A PROGRAM.]

\section{Policy 32: $\quad$ Rare and Endangered Species Survey}

The State Department of Fish and Game should continue to identify rare or endangered plant and animal species within the county. [THIS POLICY SHALL BE IMPLEMENTED AS A PROGRAM.]

\section{Policy 33: $\quad$ Protection of Vegetation}

Vegetation which is rare or endangered or serves as cover for endangered wildlife shall be protected against any significant disruption of habitat value. All development shall be designed to disturb the minimum amount possible of wildlife or plant habitat. [THIS POLICY SHALL BE IMPLEMENTED PURSUANT TO SECTION 23.07.176 OF THE CZLUO.] 


\section{Policy 34: $\quad$ Protection of Dune Vegetation}

Disturbance or destruction of any dune vegetation shall be limited to those projects which are dependent upon such resources where no feasible alternatives exist and then shall be limited to the smallest area possible. Development activities and uses within dune vegetation shall protect the dune resources and shall be limited to resource dependent, scientific, educational and passive recreational uses. Coastal dependent uses may be permitted if it can be shown that no alternative location is feasible, such development is sited and designed to minimize impacts to dune habitat and adverse environmental impacts are mitigated to the maximum extent feasible.

Revegetation with California native plant species propagated from the disturbed sites or from the same species at adjacent sites shall be necessary for all projects. [THIS POLICY SHALL BE IMPLEMENTED AS A STANDARD.]

\section{Policy 35: $\quad$ Recreational Off-Road Vehicle Use of Nipomo Dunes}

Within designated dune habitats, recreational off-road vehicle traffic shall only be allowed in areas identified appropriate for this use. Detailed recommendations concerning protection of the dune habitat within Pismo State Beach and Pismo Vehicular Recreation area are found in the chapter regarding Recreation and Visitor-Serving Facilities. [THIS POLICY SHALL BE IMPLEMENTED AS A STANDARD.]

\section{E. MARINE HABITATS}

Marine habitats include rocky points, near-shore reefs, rocky intertidal areas, offshore rocks and kelp beds. These near and onshore areas provide habitat for marine birds, mammals, fish and invertebrates. The Coastal Act requires that the biological productivity and the quality of coastal waters appropriate to maintain optimum populations of marine organisms be maintained and that habitat areas be enhanced and, where feasible, restored. While these habitat areas are sensitive to disturbance, they have, for the most part, suffered very little degradation. Three potential impacts that might adversely affect these resources are: increased coastal access, offshore drilling and expanded marine terminal facilities. Since much of the sensitive marine habitat areas are already within state holding, protection for these areas from other potential impacts are readily available.

Recreational or commercial harvesting of any marine species is strictly controlled by the Fish and Game Code. Marine mammals are protected by the Marine Mammal Protection Act of 1972. In addition, the Endangered Species Act provides special protection to those species identified as threatened or endangered and includes the California Sea Otter and the Gray Whale. Under the Federal Water Pollution Control Act, the Regional Water Quality Control Board has authority over any waste discharge into coastal waters. The county's principal role in protection of marine habitats includes control of access and regulation of development adjacent to these areas.

The following policies relate to protection of marine habitat areas along the coast: 


\section{Policy 36: $\quad$ Protection of Kelp Beds, Offshore Rocks, Rocky Points, Reefs and Intertidal Areas}

Uses shall be restricted to recreation, education and commercial fishing. Adjacent development shall be sited and designed to mitigate impacts that would be incompatible with the continuance of such habitat areas. [THIS POLICY SHALL BE IMPLEMENTED AS A STANDARD.]

\section{Policy 37: $\quad$ Siting of Shoreline Structures}

Shoreline structures, including piers, groins, breakwaters, seawalls and pipelines, shall be designed or sited to avoid and minimize impacts on marine habitats. [THIS POLICY SHALL BE IMPLEMENTED PURSUANT TO SECTION 23.07.178 OF THE CZLUO.]

\section{Policy 38: $\quad$ Shoreline Access Consistent with Habitat Protection}

Coastal access shall be monitored and regulated to minimize impacts on marine resources. If negative impacts are demonstrated, then the appropriate agency shall take steps to mitigate these impacts, including limiting the use of coastal access. [THIS POLICY SHALL BE IMPLEMENTED PURSUANT TO SECTIONS 23.07.178 AND 23.04.420j OF THE CZLUO.]

\section{Policy 39: $\quad$ Habitat Signs}

The appropriate agency (in conjunction with the county Fish and Game Commission) should provide signs indicating that collecting from tide pools, etc., is illegal. [THIS POLICY SHALL BE IMPLEMENTED AS A PROGRAM.]

\section{Policy 40: $\quad$ Marine Sanctuary Designation}

The county should continue to investigate whether appropriate offshore areas should be nominated for Marine Sanctuary Designation. [THIS POLICY SHALL BE IMPLEMENTED AS A PROGRAM.]

\section{RELATIONSHIP TO THE LAND USE ELEMENT / COASTAL ZONE LAND USE ORDINANCE}

Environmentally sensitive habitat areas are mapped and discussed in the Local Coastal Plan as Sensitive Resource Areas (SRA). SRA's are applied in addition to a basic land use as a combining 
overlay designation. Combining designations are established to highlight the need for more intensive project review in areas where additional performance standards may be required. These designations are applied through both the text and the maps of the Land Use Element, and are used in conjunction with the land use categories to guide land use patterns. Proposed development within or near a sensitive resource area will be reviewed in accordance with these policies, applicable planning area standards for the SRA and ESH combining designations, and Sections 23.07.160-178 of the Coastal Zone Land Use Ordinance.

Note that not all areas identified as Sensitive Resource Areas (SRA) reflect an environmentally sensitive habitat as defined by the Coastal Program. The SRA combining designation has also been used to identify non-habitat related concerns for visual siting issues. The overlay process allows for a more specific review of siting alternatives to ensure protection of both habitat and scenic values.

The principal implementation tool for applying Land Use Element policies to land development activities is the Coastal Zone Land Use Ordinance. The Coastal Zone Land Use Ordinance establishes performance criteria and procedures for development review.

\section{Findings}

The policies outlined in this chapter provide for the protection of environmentally sensitive habitat ESH areas as required by the Coastal Act. The ESH areas have been mapped in the LUE and appropriate setbacks from habitat areas have been established.

Shoreline retaining structures will be permitted only where they would be constructed consistent with habitat preservation as required by Section 30235. The county will work with the State Department of Fish and Game and the State Water Resources Control Board to ensure that development is sited in accordance with Section 30230. The environmentally sensitive resource areas in the land use plan. The standards and programs outlined in each planning area and the criteria outlined in the Coastal Zone Land Use Ordinance will ensure the protection of biological productivity and quality of coastal habitats as required by Section 30231 . 
City of Morro Bay Scenic Highway Corridor Protection Plan 


\author{
CITY OF MORRO BAY \\ Scenic Highway Corridor Protection Plan
}

\title{
Regulation of Land Use (density and allowable land uses)
}

The City of Morro Bay is the only incorporated city and the most densely populated area along the route. The land use designations along the scenic corridor within the city limits include residential, commercial, industrial and agriculture, with a portion of the southern area of the City zoned Open Space Recreation. 'Me City is almost entirely within the Coastal Zone. The City's land use regulations contained within its General Plan, certified Local Coastal Program Land Use Plan and implementing ordinances must be consistent with the California Coastal Act. The City's General Plan and Local Coastal Program Land Use Plan are contained in two (2) documents, with the policies and programs within the General Plan Elements mirroring those within the Local Coastal Program Land Use Plan. Morro Bay Municipal Code Section 17.24 (Primary Districts) contains the Zoning District standards for the land use designations. The district standards are attached as Exhibit "A".

\section{${ }_{0}$ Site Planning (review authority for proposed developments)}

All new development within the City of Morro Bay must receive an approved Coastal Development Permit prior to issuance of a building permit. The California Coastal Commission has direct permit authority up to the mean high tide line, with the remaining land within the Coastal Zone under the City of Morro Bay's permit authority. Developments within the Coastal Commission's appeal jurisdiction (generally those areas within 300' of the first public road or within 100' of an environmentally sensitive habitat area) are appealable to the Coastal Commission. Morro Bay Municipal Code Chapters 17.58 (Coastal Development Permits and Procedures) and 17.60 (Use Permit Procedures, Notices and Variances) require discretionary review of detailed land and site plans for new development that must be found consistent with the General Plan, Local Coastal Program Land Use Plan and the California Coastal Act. The review process for approving new development within the City of Morro Bay is as follows:

Administrative Coastal Permits: New residential construction on sites located outside of the Coastal Appeal jurisdiction and minor commercial construction require Administrative Coastal Permit approval. Administrative permits are issued directly by the Planning Department following the required ten (10) day noticing period, and are conditioned to meet all applicable codes and ordinances. Administrative actions are appealable to the Planning Commission within ten (10) days of the action approving the permit. The Planning Commission at a noticed public hearing hears appeals. Planning Commission actions are appealable to the City Council. The City Council has final permit authority over projects that are not appealable to the Coastal Commission pursuant to Coastal Act Section 30603.

2. Regular Coastal Permits: New residential construction on sites within the Coastal Appeal Jurisdiction and new commercial projects require Regular Coastal Permit approval. Regular Coastal Permits are reviewed by the Planning Commission at duly noticed public hearings. The Planning Commission reviews the project's compliance with General Plan, Local Coastal Program Land Use Plan and applicable Zoning Codes. The Planning Commission's action is appealable to the City Council and if the site is located within the Coastal Appeal Jurisdiction or meets the criteria with Coastal Act Section 30603, the Council's action is appealable to the Coastal Commission.

Applicable Zoning Ordinance Code Sections, General Plan and Local Coastal Program Land Use Policies and Programs which govern site planning within the City of Morro Bay are listed as follows, and attached as Exhibit "B": 
Morro Bay Municipal Code Chapter 17 (Zoning Ordinance) Section 17.48.190: Protection of Visual Resources and Compatible Design. Visual Resources and Scenic Highways Element Policies and Programs: a. Policy VR-1; b. Policy VR-2, Programs VR-2.1 and VR-2.2; c. Policy VR-3, Programs VR-3.4, VR-3.5, and VR-3.6. Safety Element Policies and Programs: a. Policy S-6, Programs S-6. 1, S-6.2, and S-6.3; b. Policy S-7, Programs S-7. 1, S-7.2, and S-7 * 3. Local Coastal Program Land Use Plan Policies Chapter X Hazards a. Policies 9.04, 9.05, 9.06, 9.07, 9.08, 9.09; Local Coastal Program Land Use Plan Policies Chapter XIII Visual Resources: a. Policy 12.04, 12.06, 12.07, 12.08, 12.09, 12.10 and 12.11

\section{Prohibition of off-site outdoor advertising, and control of on-site advertising}

Morro Bay Municipal Code Section 17.68 contains the City's sign regulations which prohibits new billboards within our City limits and governs the size and height of on-site outdoor advertising visible from the highway. Section 17.68 is attached as Exhibit "C".

\section{Control of earthmoving and landscaping (grading ordinances, landscaping requirements)}

Grading within the Coastal Zone is considered "development" under the Coastal Act and requires a Coastal Development Permit. General Plan Safety Element Program S-6.2 states that plans for development shall minimize cut and fill operations. Plans showing excessive cutting and filling shall be modified or denied if it is determined that the development could be carried out with less alteration of the natural terrain. Program S-6.3 states that all development shall be designed to fit the site topography, soils, geology, hydrology, and other existing conditions and be oriented so that grading and other site preparation is kept to an absolute minimum. To accomplish this, structures shall be built to existing natural grade whenever possible. Natural features, landforms, and native vegetation, such as trees, shall be preserved to the maximum extent feasible. S7.1 notes that for permitted grading operations on hillsides, the smallest practical areas of land shall be exposed at any one dime during development, and the length of exposure shall be kept to the shortest practicable amount of time. Local Coastal Program Land Use Polices 9.05, 9.06 and 9.07 mirror the General Plan programs. These programs and policies are attached as part of Exhibit "B".

\section{* Design and appearance of structures and equipment (utility structures, etc.)}

Morro Bay Municipal Code Section 17.48.050 sets the standards for undergrounding of utility lines and states "all utility service lines to all new development, except single family residences, on vacant lands (including the demolition and replacement of individual structures), and to major redevelopment projects, shall be undergrounded. For any project 1.5 acres or larger, all electric distribution and communication lines located on or immediately adjacent to the project site shall be undergrounded in accordance with the applicable rules and regulations of the California Public Utilities Commission." Morro Bay Municipal Code Section 17.30 (Special Uses) requires a Special Use Permit for locating public utility facilities with special findings that address the routes of all new lines. This section states that the routes of all new lines shall, to the maximum extent feasible, avoid important coastal resources such as recreation and environmentally sensitive areas, including the undergrounding of utility facilities. Local Coastal Program Land Use Plan Chapter VII (Energy/Industrial Development) Policy 5.08 states "The City will require that new pipelines and transmission lines are installed with suitable mitigation measures such as erosion control, revegetation, and other measures necessary to protect all scenic resources and habitat values. 


\section{Inventory of Overlooks}


1.

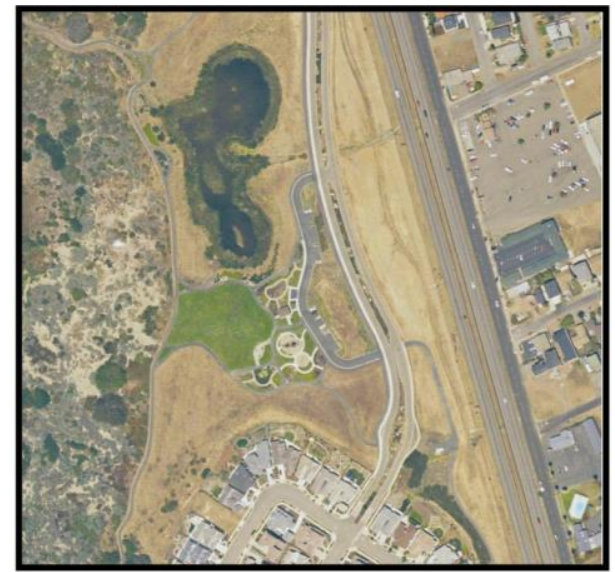

Location: Cloisters, MB (PM 30.8) Size: $\sim 25$ spaces Visitor Amenities: Restrooms, park, trails, benches, tables Ingress/egress: N/A

Planned Improvements - Interpretive signage

2.

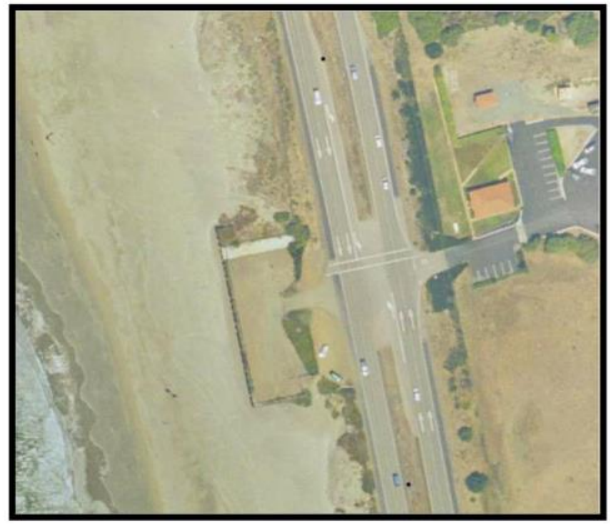

Location: PM 32.5 Size: $~ 10$ spaces

Visitor Amenities: None

Ingress/egress: 160' left-turn lane, 8 foot shoulders

Planned Improvements - TBD

3.

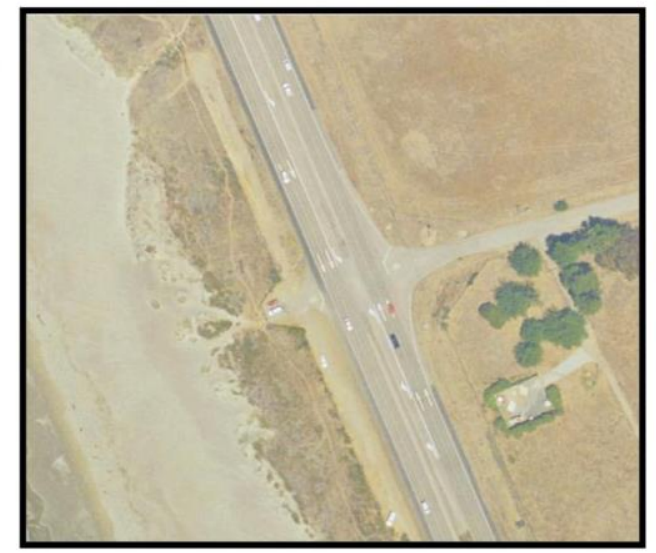

Location: PM 32.75 Size: $\sim 40$ speces

Visitor Amenities: None

Ingress/egress: 230' left-turn lane, 8 foot shoulders

Planned Improvements - Reduce in size and enhance
4.

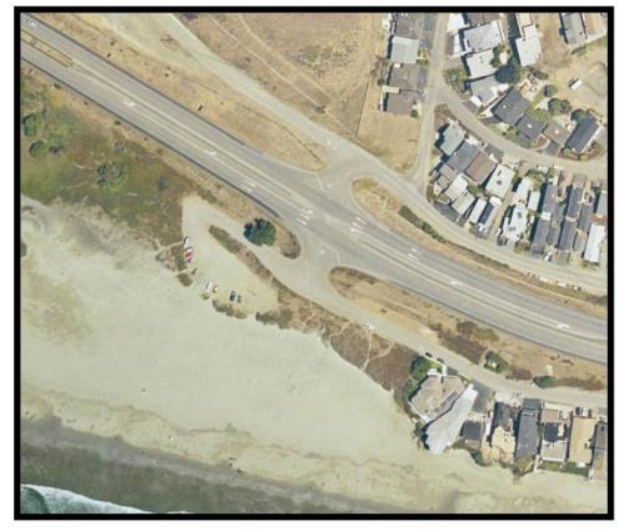

Location: PM 34.3 Size: $\sim 30$ spaces

Visitor Amenities: Beach access Ingress/egress: N/A

Planned Improvements - TBD

5.

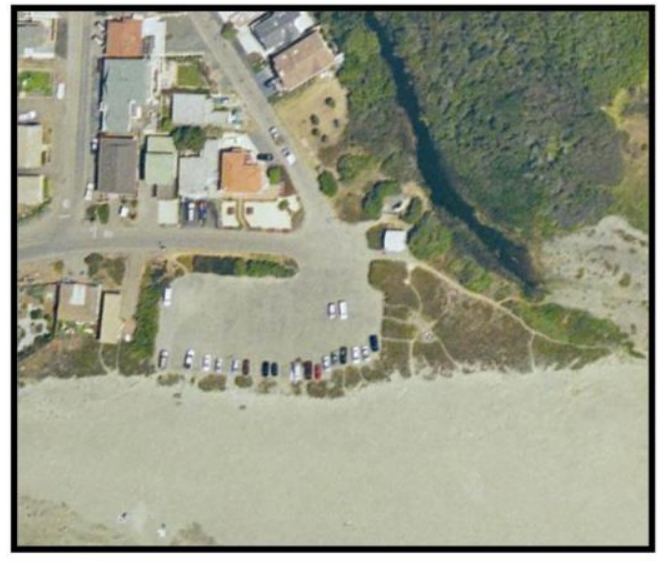

Location: PM 34.4 Size: 75spaces

VisitorAmenities: Restrooms, beach access Ingress/egress: N/A

Planned Improvements - TBD

6.

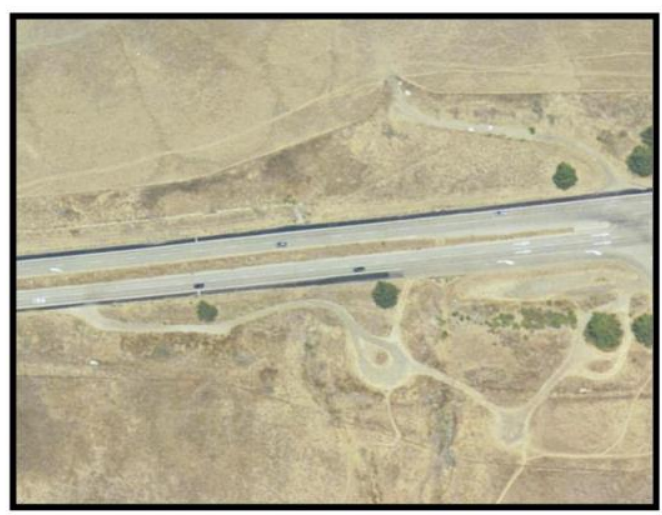

Location: PM 36.7 Size: N/A

Visitor Amenities: None

Ingress/egress: None

Planned Improvements - Establish and enhance 
7.

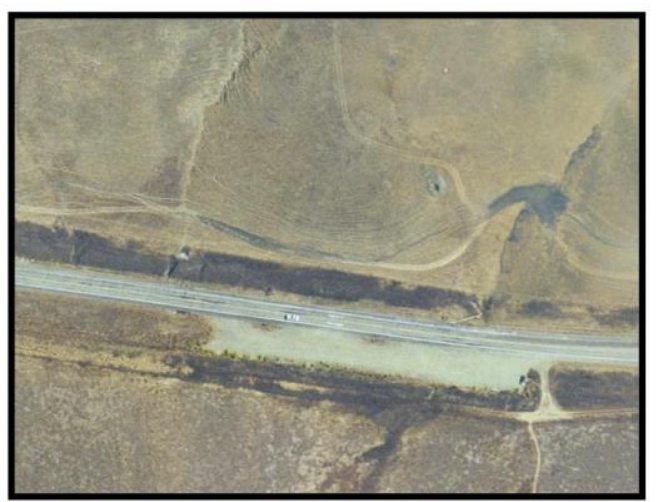

Location: PM 37.1 Size: $\sim 50$ ' X 480' spaces

Visitor Amenities: None

Ingress/egress: None

Planned Improvements - Reduce in size and enhance

8.

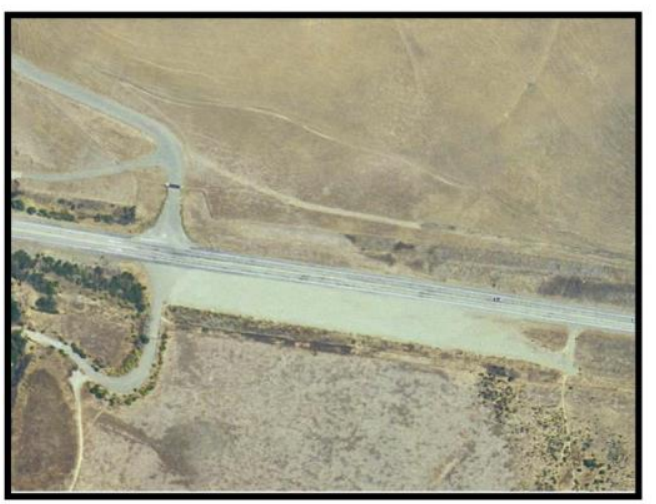

Location: PM 37.4 Size: $\sim 60^{\prime} \times 600^{\prime}$

Visitor Amenities: None

Ingress/egress: None

Planned Improvements - Reduce in size and enhance

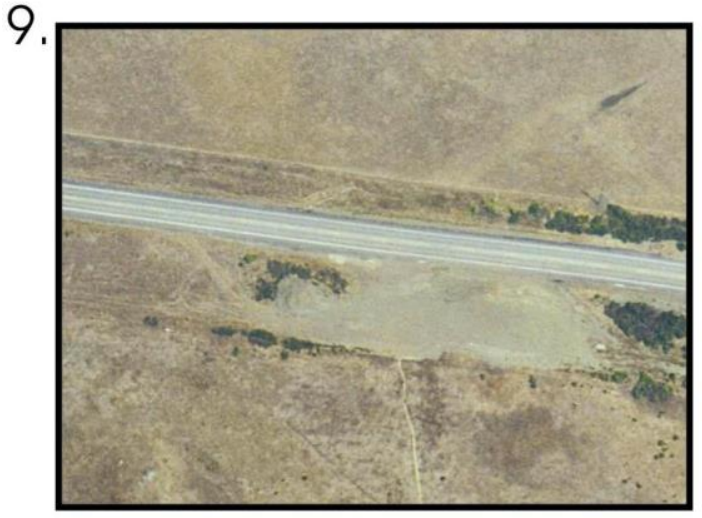

Location: PM 37.6 Size: $\sim 50$ ' X 340' spaces

Visitor Amenities: None

Ingress/egress: None

Planned Improvements - Emergency Access only
10

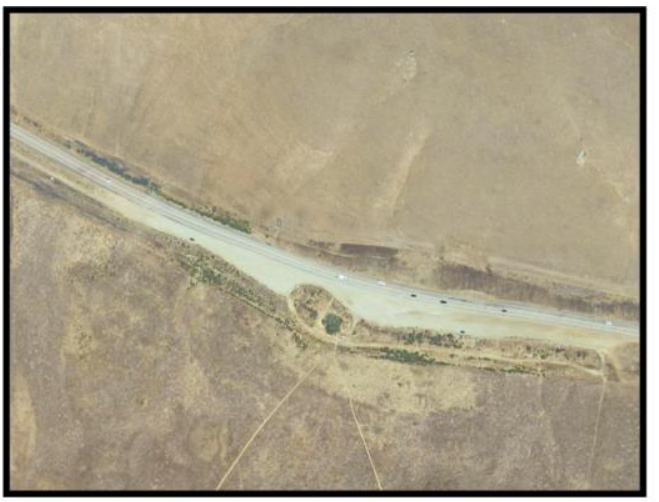

Location: PM 38 Size: $~ 50^{\prime}$ X 1200' spaces

Visitor Amenities: None

Ingress/egress: None

Planned Improvements - Reduce in size and enhance

11.

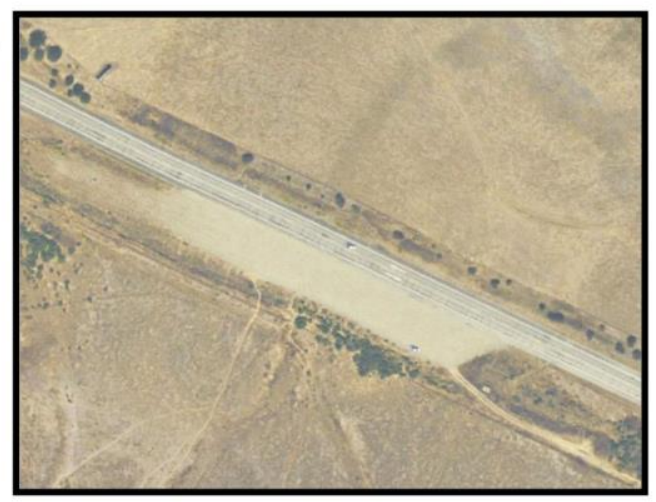

Location: PM 38.6 Size: $\sim 50^{\prime} \times 340^{\prime}$ spaces

Visitor Amenities: None

Ingress/egress: None

Planned Improvements - Emergency Access only

12.

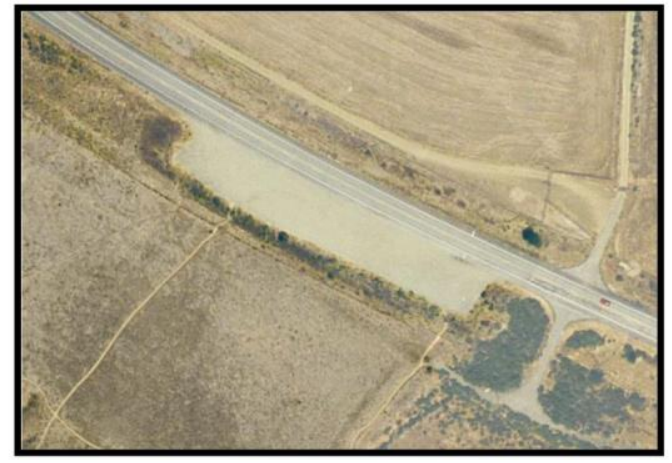

Location: PM 38.8 Size: $\sim 60^{\prime} X 440^{\prime}$ spaces

Visitor Amenities: None

Ingress/egress: None

Planned Improvements - Reduce in size and enhance 
13

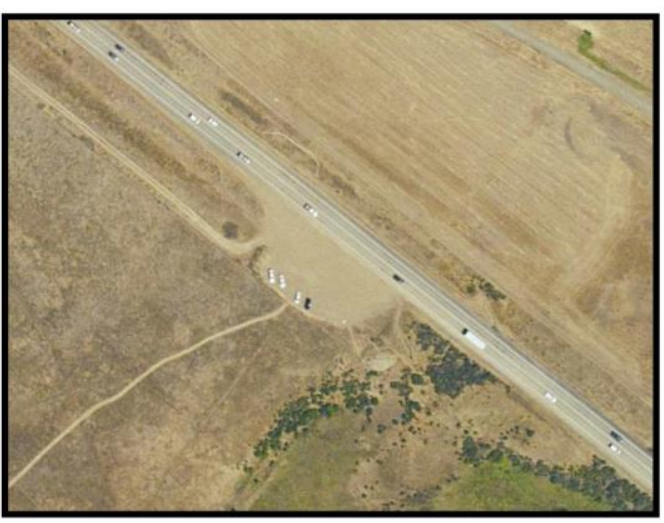

Location: PM 39.5 Size: 15 spaces

Visitor Amenities: None

Ingress/egress: None

Planned Improvements Close to consolidate parking

14.

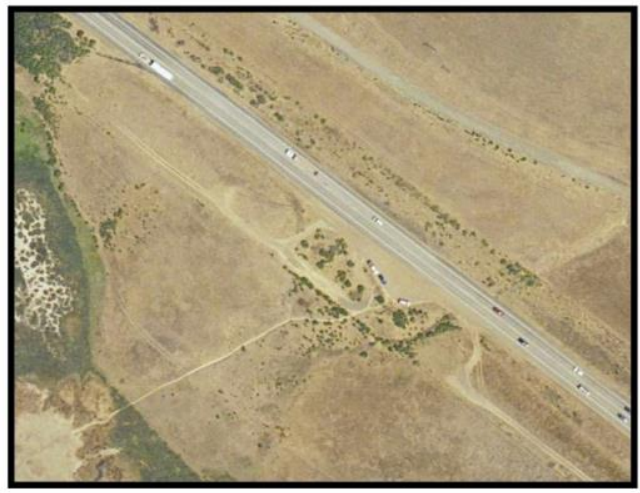

Location: PM39.6 Size: $~ 10$ spaces

Visitor Amenities: None

Ingress/egress: None

Planned Improvements: Close to consolidate parking

15.

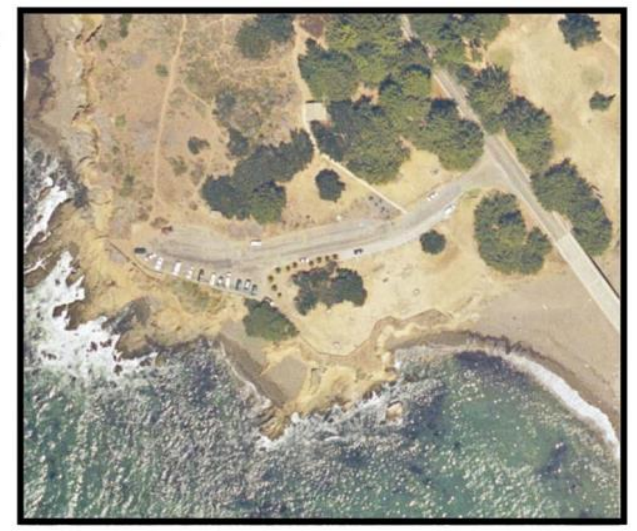

Location: Moonstone Beach (PM 52) Size: 30 spaces Visitor Amenities: Restrooms, benches, tables, Interpretive Kiosk

Ingress/egress: NA

Planned Improvements TBD
16.

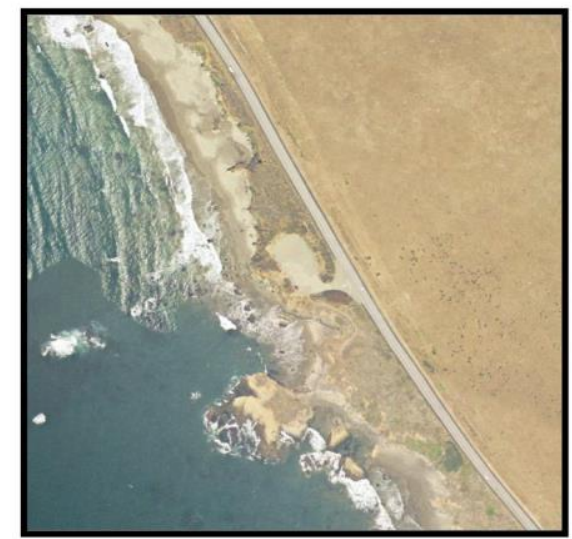

Location: PM 55.5 Size: $90^{\prime}$ X190' 30 spaces Visitor Amenities: None

Ingress/egress: None

Planned Improvements - TBD

17.

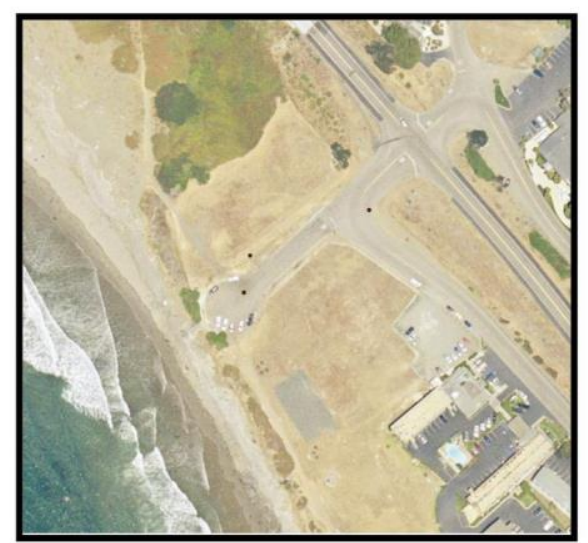

Location: N. San Simeon (PM 54.8) Size: 12 spaces Visitor Amenities: None Ingress/egress: NA

Planned Improvements - TBD

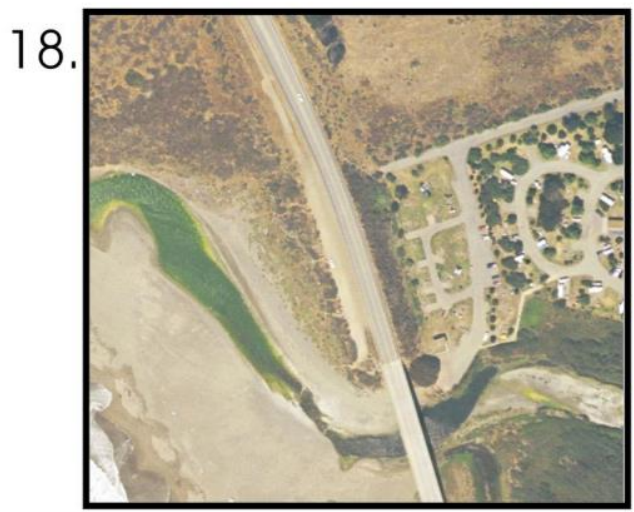

Location: San Simeon State Park (PM 53) Size: 330'X 25' Visitor Amenities: None

Ingress/egress: None

Planned Improvements - TBD 
19.

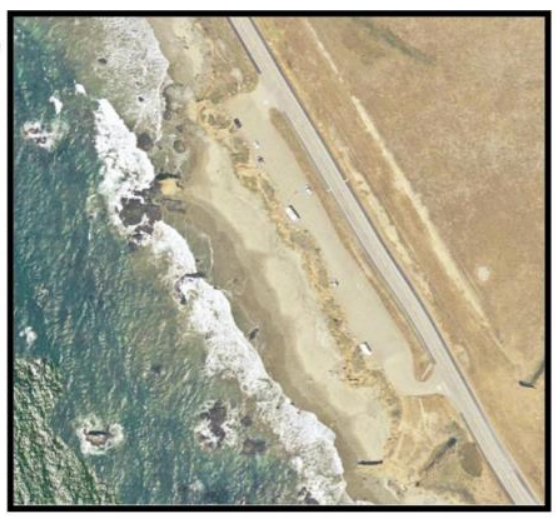

Location: PM 56.1 Size: 40' X 600'

Visitor Amenities: None

Ingress/egress: None

Planned Improvements - TBD

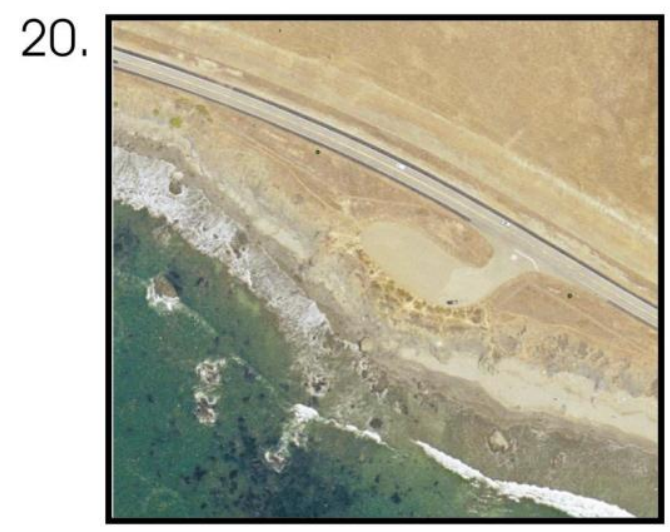

Location: N. Elephant Seal (PM 63) Size: $\sim 20$ spaces Visitor Amenities: None

Ingress/egress: No Channellization

Planned Improvements:

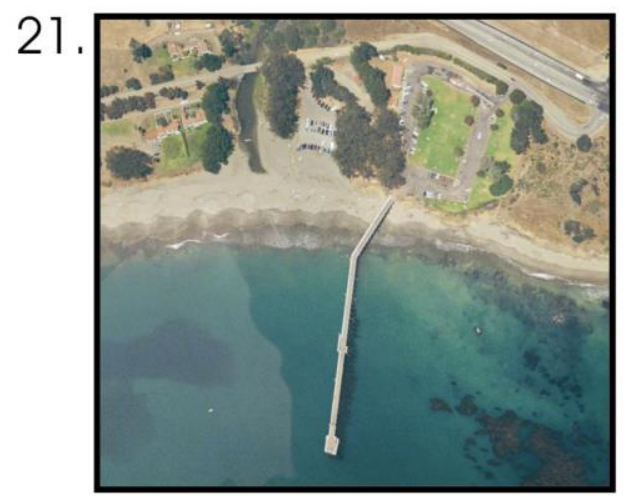

Location: W. Randolph Hearst State Beach (PM 58.1) Size: $\sim 150$ spaces

Visitor Amenities: Interpretive signage/kiosks/exhibits, Coastal Discovery Center, Restrooms, benches/tables.

Ingress/egress: Left-turn Channelization, right hand shoulders Planned Improvements Construct boardwalk to connect with existing boardwalk to the south.
22.

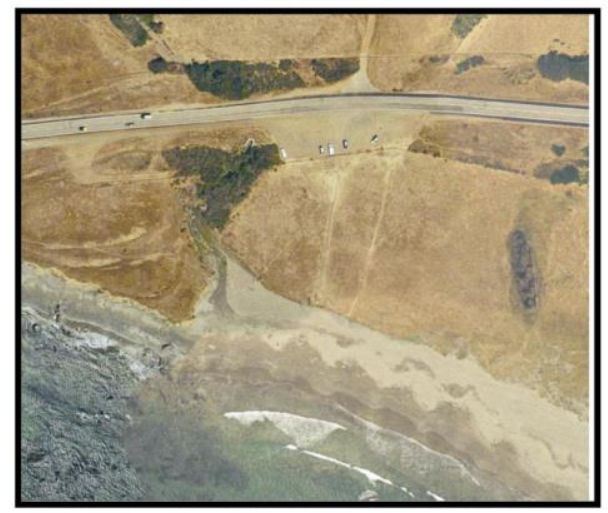

Location: PM 60.4 Size: .4 Acres

Visitor Amenities: None

Ingress/egress: None

Planned Improvements CCT access

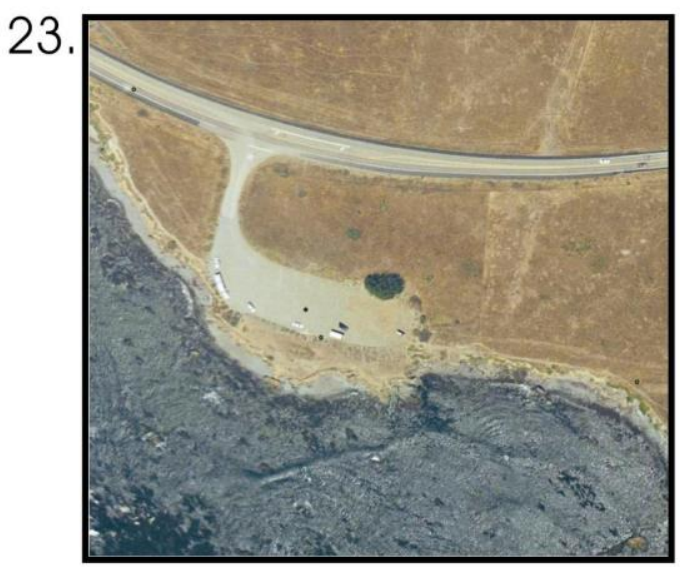

Location: PM 61.6 Size: $\sim 20$ spaces

Visitor Amenities: None

Ingress/egress: Left-turn Channelization (200'), right hand shoulders

Planned Improvements CCT access, Interpretive Signage

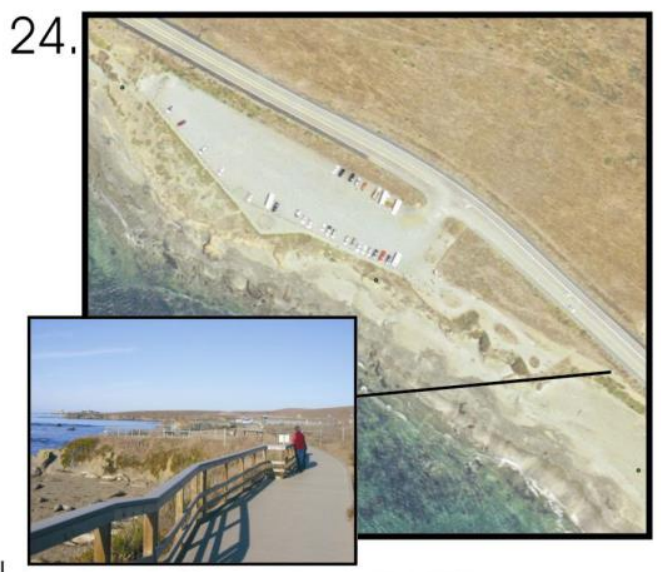

Location: S. Elephant Seal (PM 62.7)

Size: $\sim 50$ spaces

Visitor Amenities: boardwalk, Interpretive signage/kiosk, benches Ingress/egress: Left-turn Channelization (500'), 8' right hand shoulders 


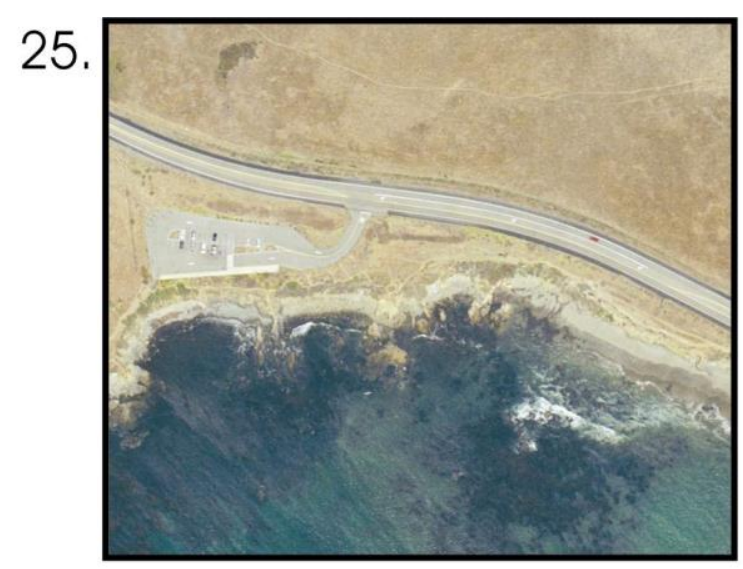

Location: N. Elephant Seal (PM 63) Size: $\sim 20$ spaces Visitor Amenities: Interpretive Signage Ingress/egress: Left-turn Channelization $\left(490^{\prime}\right), 8^{\prime}$ right hand shoulders

Planned Improvements Construct boardwalk to connect with existing boardwalk to the south.

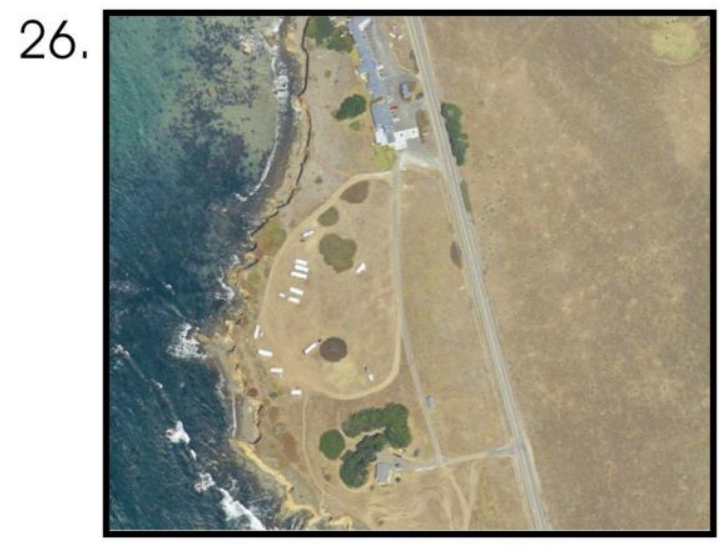

Location: Piedras Blancas Hotel(old) (PM 65.3) Size: 3.2 acres

Visitor Amenities: TBD

Ingress/egress: No Channelization

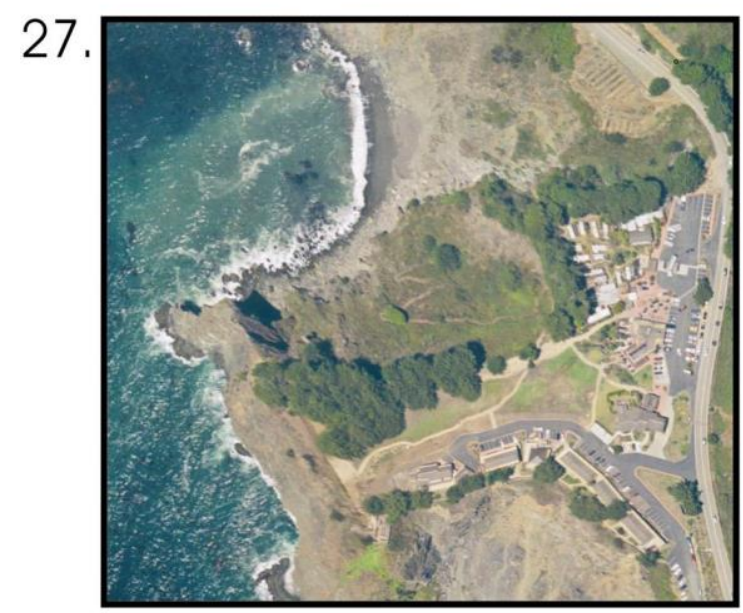

Location: Ragged Point (PM 72.9) Size: $\sim 20$ spaces

Visitor Amenities: Full Service restuarant/hotel, benches, vistas Ingress/egress: Left-turn Channelization, right hand shoulders Planned Improvements Construct boardwalk to connect with existing boardwalk to the south. 


\section{APPENDIX G}

${ }^{\text {COAST }}{ }^{8}$ 会

Economic Analysis Inputs and Assumptions 


\section{Welcome to America's Byways ${ }^{(\circledast)}$ Resource Center's Economic Impact Tool}

\section{Please Choose an Option:}

1 Enter/Edit Economic Activity Data

2 Enter/Edit Tax Rate Data

$3 \quad$ Enter/Edit Multiplier Data

4 View Impact Analysis Results 


\section{Enter Basic Information}
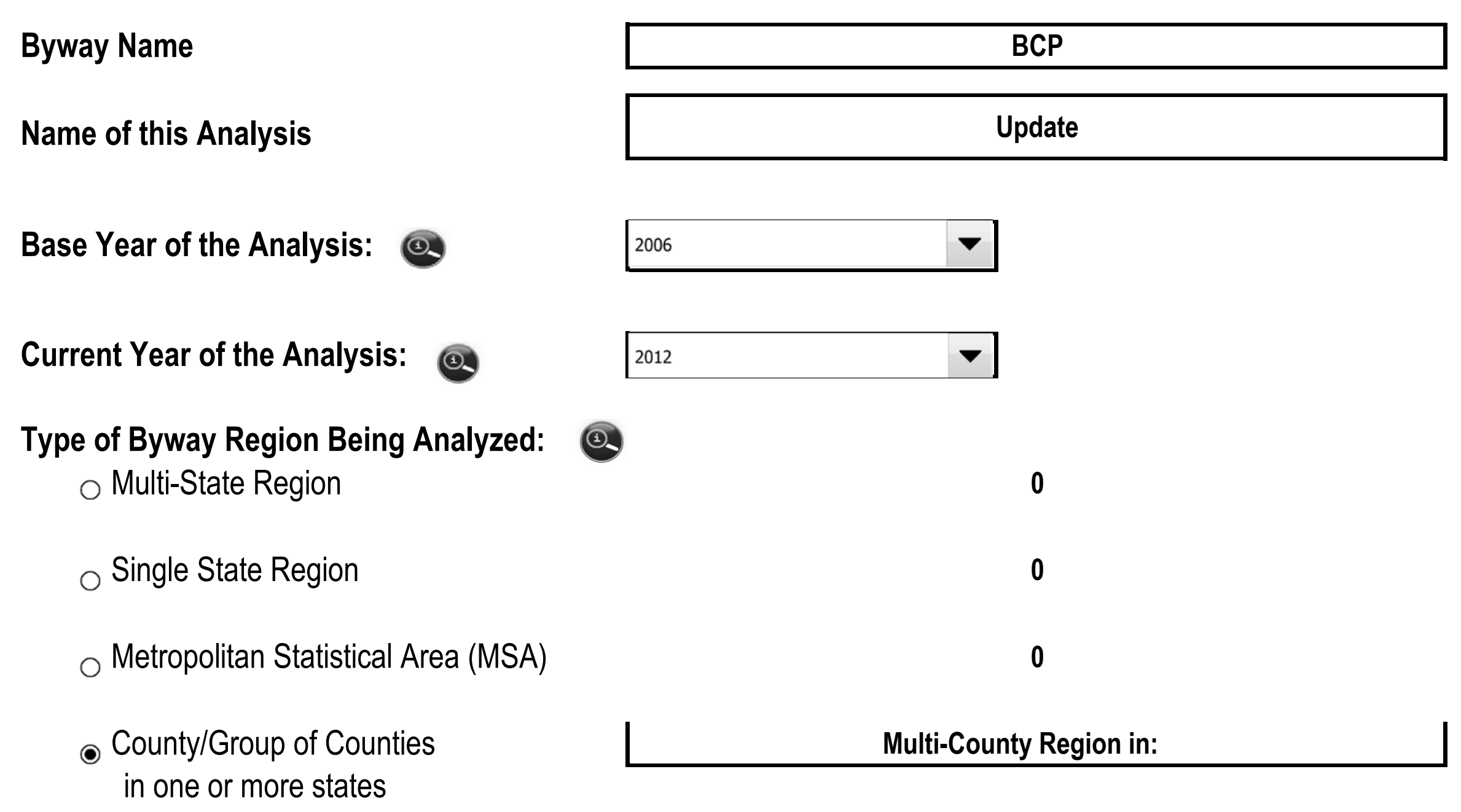

Resource
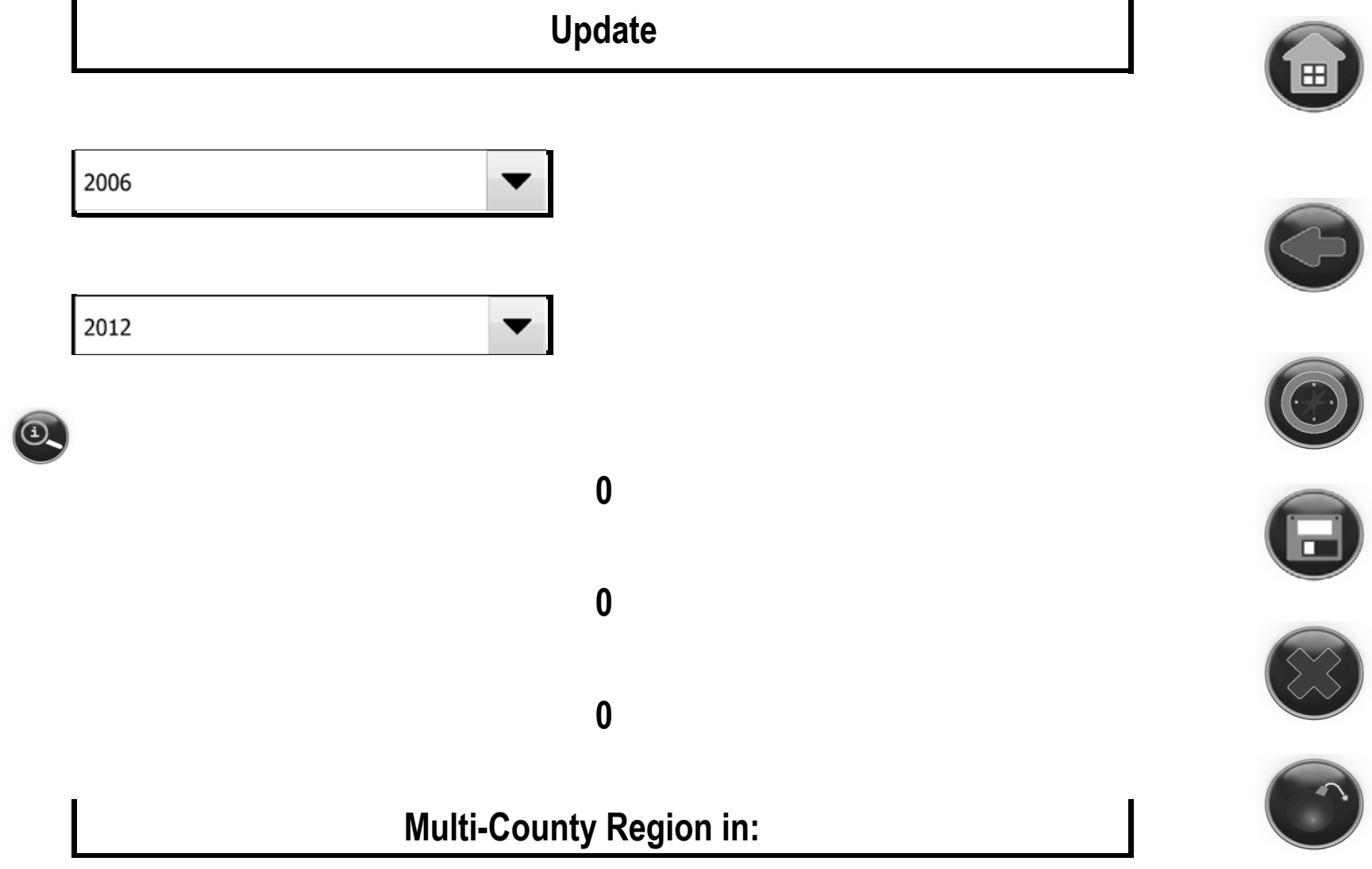

in one or more states 


\section{Enter Visitor Profile Data}

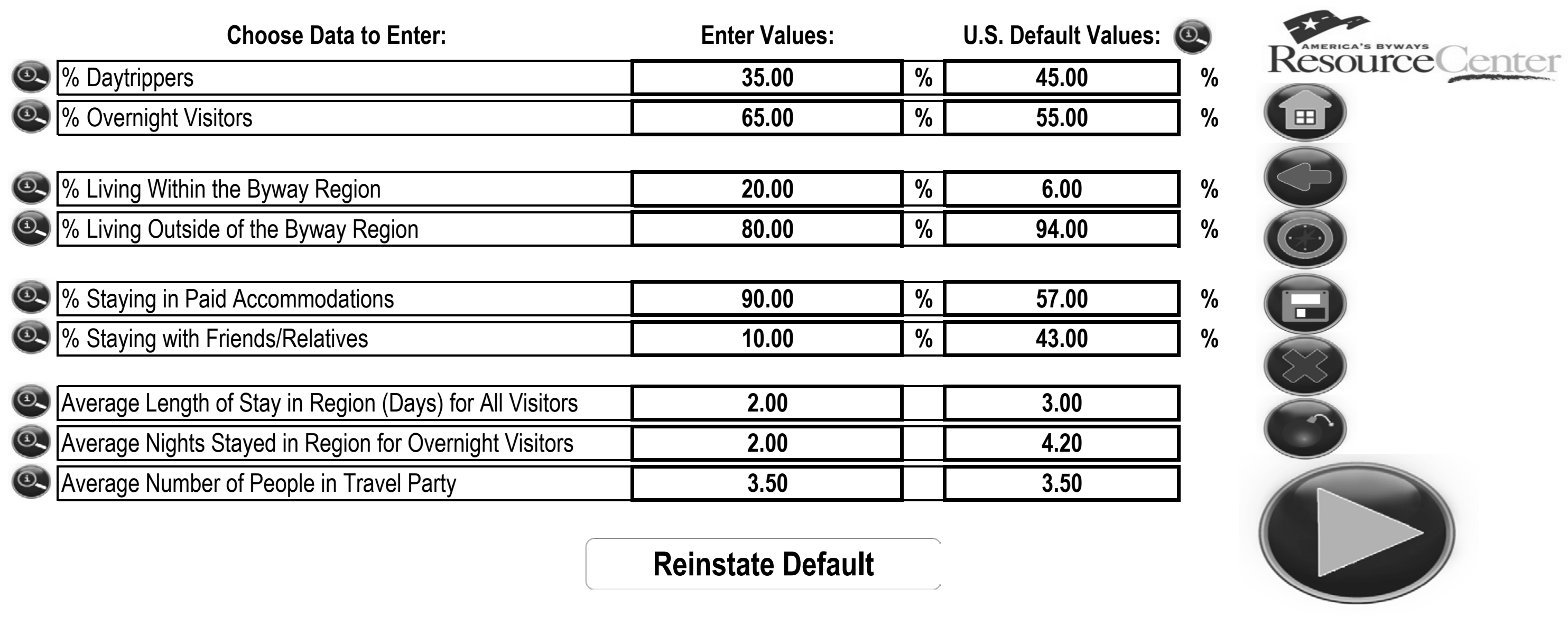




\section{Enter Visitor Spending Data}

Optional: Refine Spending Figures for tt Proceed carefully to preserve accuracy

Most changes in spending impact stem from 1 current year differed dramatically from the defa the spinners to increas

\section{Spending Categories}

Entertainment \& Recreation

Restaurant Food/Drink

Groceries

Gas Stations

Private Hotels/Campgrounds

Public Campgrounds/Lodges

Rental Homes/Cottages

Transportation

Retail Purchases

Services Purchases

Total Visitor Spending
Amount Spent

Taxable?

Total Annual Spending in Region

\begin{tabular}{|c|c|c|c|c|}
\hline O & & $\mathrm{ONC}$ & $\$$ & $86,250,000.00$ \\
\hline 0 & Yes & $\mathrm{ON}^{2}$ & $\$$ & $189,200,000.00$ \\
\hline O & Yes & $\mathrm{ON}^{2}$ & $\$$ & $26,700,000.00$ \\
\hline O & Yes & $\mathrm{ONC}$ & $\$$ & $55,845,000.00$ \\
\hline O & Yes & $\mathrm{ONc}$ & $\$$ & $97,577,150.00$ \\
\hline O & Yes & $\mathrm{ONC}$ & $\$$ & $2,706,300.00$ \\
\hline O & Yes & O N N & $\$$ & $15,937,100.00$ \\
\hline 0 & Yes & $\mathrm{ONC}$ & $\$$ & $6,205,000.00$ \\
\hline O & Yes & $\mathrm{ONc}$ & $\$$ & $131,400,000.00$ \\
\hline \multirow{2}{*}{\multicolumn{2}{|c|}{$O r$}} & $\mathrm{ONc}$ & $\$$ & $34,129,450.00$ \\
\hline & & & $\$$ & $645,950,000.00$ \\
\hline
\end{tabular}

Reinstate Default Values

\begin{tabular}{|l|}
\hline No Default \\
\hline \hline No Default \\
\hline \hline No Default \\
\hline \hline No Default \\
\hline \hline No Default \\
\hline \hline No Default \\
\hline \hline No Default \\
\hline \hline No Default \\
\hline \hline No Default \\
\hline \hline No Default \\
\hline \hline No Default \\
\hline
\end{tabular}

U.S. Default Values:

No Default

Base Year Adjusted Figures

\begin{tabular}{|r|c|rr|}
\hline$-15 \%$ & $\vdots$ & $\$$ & $73,312,500.00$ \\
\hline \hline$-30 \%$ & $\vdots$ & $\$$ & $132,440,000.00$ \\
\hline \hline$-20 \%$ & $\vdots$ & $\$$ & $21,360,000.00$ \\
\hline$-20 \%$ & $\vdots$ & $\$$ & $44,676,000.00$ \\
\hline \hline$-30 \%$ & $\vdots$ & $\$$ & $68,304,005.00$ \\
\hline \hline $0 \%$ & $\vdots$ & $\$$ & $2,706,300.00$ \\
\hline \hline$-15 \%$ & $\vdots$ & $\$$ & $13,546,535.00$ \\
\hline \hline$-20 \%$ & $\vdots$ & $\$$ & $4,964,000.00$ \\
\hline \hline$-15 \%$ & $\vdots$ & $\$$ & $111,690,000.00$ \\
\hline \hline$-20 \%$ & $\vdots$ & $\$$ & $27,303,560.00$ \\
\hline & & $\$$ & $500,302,900.00$ \\
\hline
\end{tabular}




\section{Enter Visitor Count Data}

\section{Add New Item}

(?) Edit/Delete Existing

Total Change From 2006 to 2012:

$1,099,000$

ResOurce

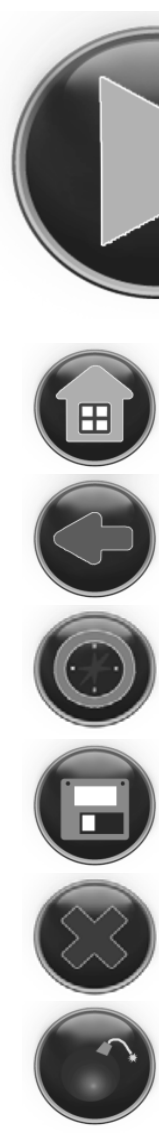

\begin{tabular}{c|c|c|c}
\cline { 4 - 4 } & \multicolumn{2}{c|}{2006} & 2012 \\
\hline No. & Location Description & Count & Count \\
\hline 0. & Byway & $5,399,000$ & $6,498,000$ \\
\hline 0. & 0. & 0 & 0 \\
\hline 0. & 0. & 0 & 0 \\
\hline 0. & 0. & 0 & 0 \\
\hline 0. & 0. & 0 & 0 \\
\hline 0. & 0. & 0 & 0 \\
\hline 0. & 0. & 0 & 0 \\
\hline 0. & 0. & 0 & 0 \\
\hline 0. & 0. & 0 & 0 \\
\hline 0. & 0. & 0 & 0 \\
\hline 0. & 0. & 0 & 0 \\
\hline 0. & 0. & 0 & 0 \\
\hline 0. & 0. & 0 & 0 \\
\hline 0. & 0. & 0 & 0 \\
\hline 0. & 0. & 0 & 0 \\
\hline 0. & 0. & 0 & 0 \\
\hline 0. & 0. & 0 & 0 \\
\hline 0. & 0. & 0 & 0 \\
\hline
\end{tabular}




\section{Enter Investment Data (Public \& Private)}

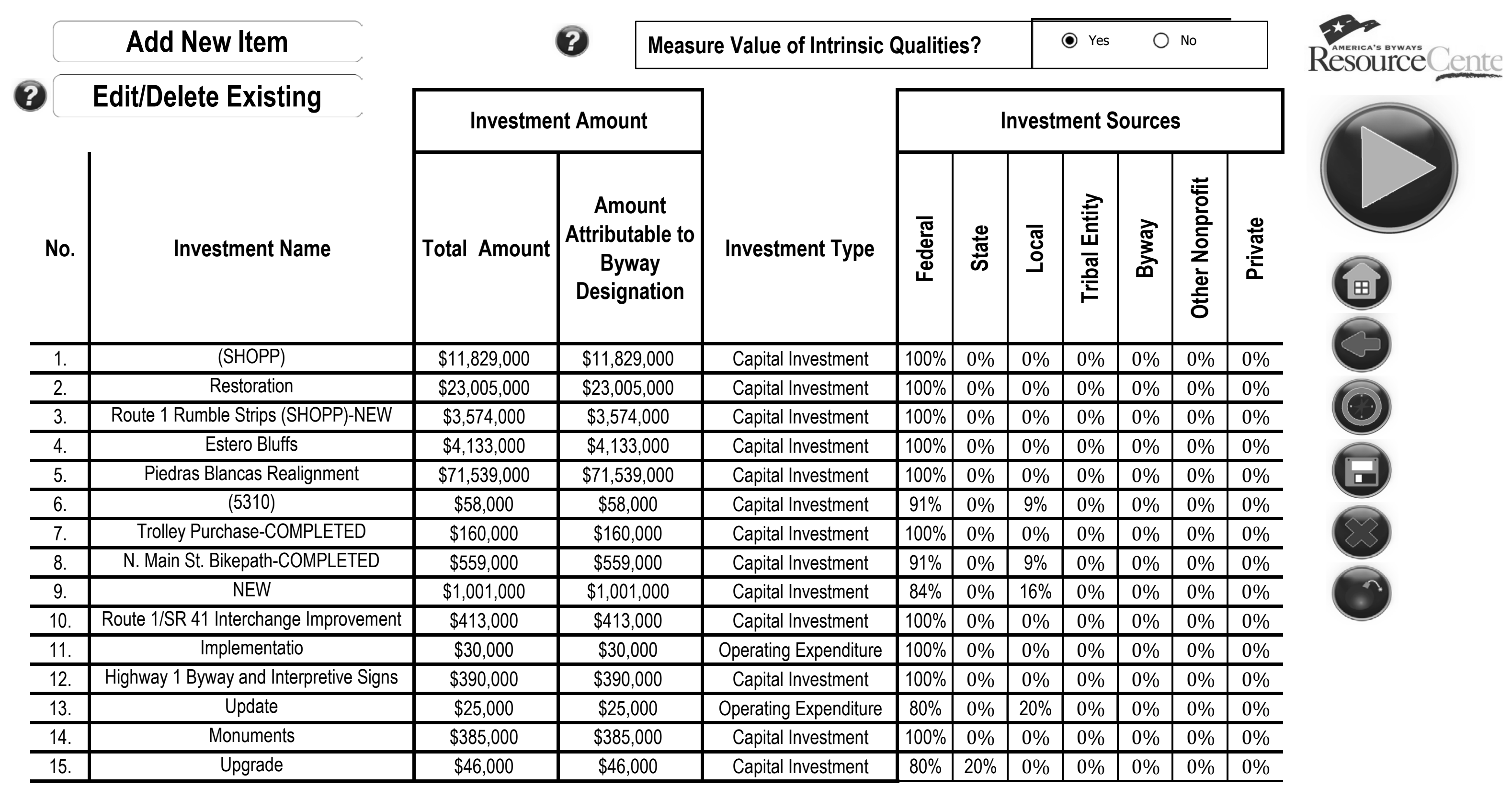




\section{Enter Investment Data}

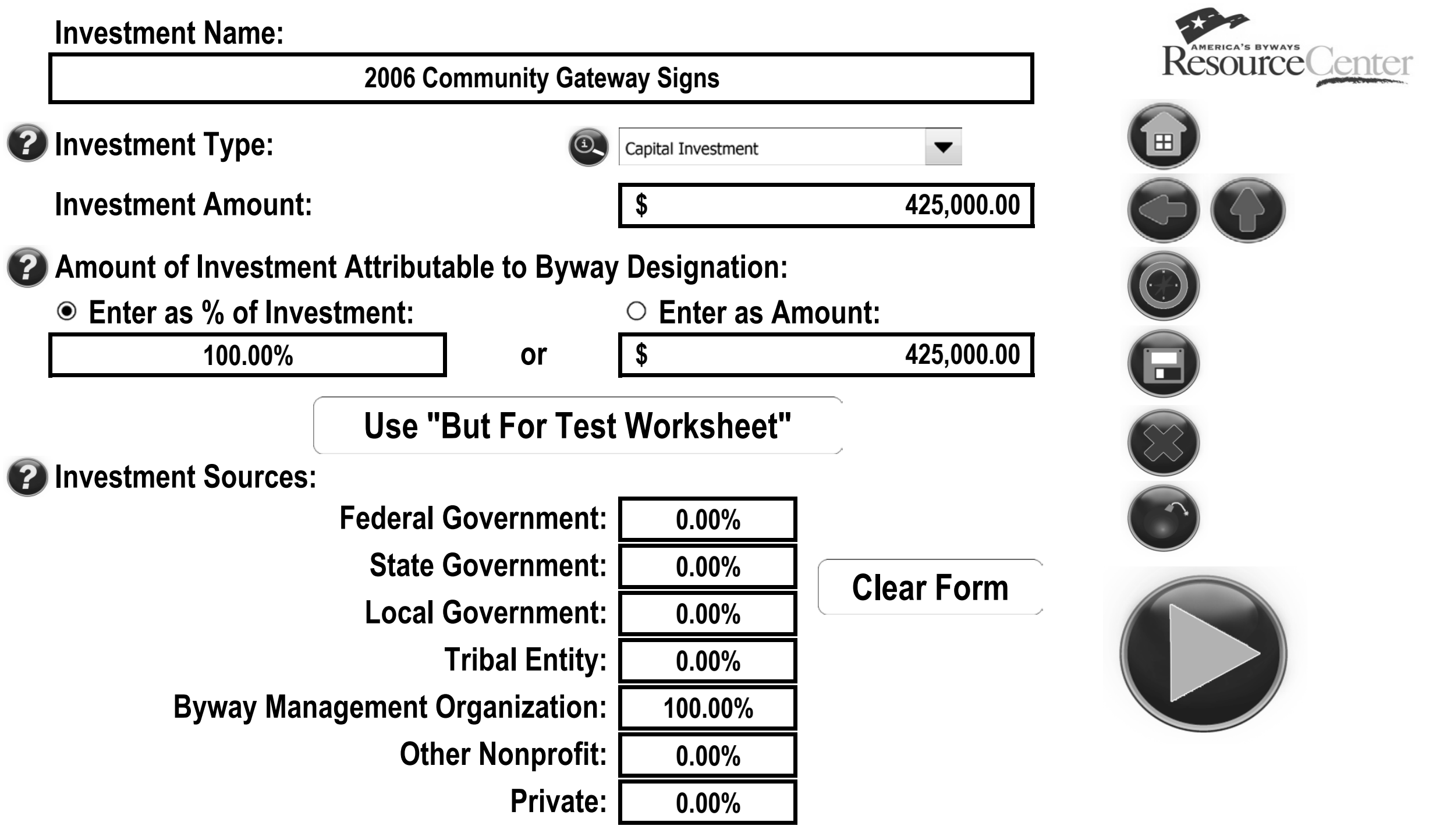




\section{The "But For Test": A Worksheet}

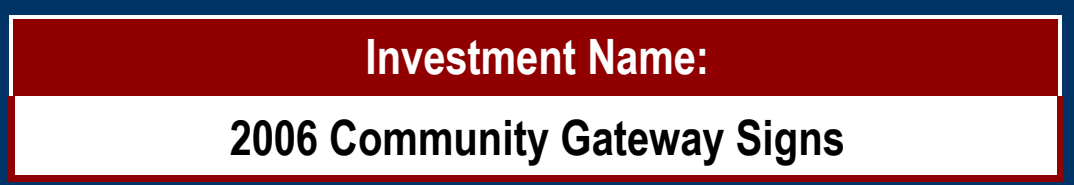

\section{Community Gateway Signs}

No. Factor

1. Proximity to the Byway (3)

2. Not part of regular maintenance

(3)

3. Investors sought out Byway information

(1).

4. Investors asked Byway group for support

(3)

5. Byway cited as contributing factor

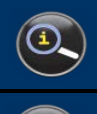

6. Byway group helped get funding

(3)

7. Marketed as being along Byway

(2)

8. Contributes to user enjoyment of Byway

9. Byway group is touting the investment

10. Comfortable publicly attributing investment to Byway

\begin{tabular}{|c|c|c|}
\hline & Weight & 0 \\
\hline $100 \%$ & 0 \\
\hline $100 \%$ & 0 \\
\hline $100 \%$ & 0 \\
\hline $100 \%$ & 0 \\
\hline $100 \%$ & 0 \\
\hline $100 \%$ & 0 \\
\hline $100 \%$ & 0 \\
\hline $100 \%$ & 0 \\
\hline $100 \%$ & 0 \\
\hline $100 \%$ & 0 \\
\hline
\end{tabular}




\section{Enter Tax Rate Data}

Select All Type(s) of Data You Wish to Enter:

\section{Select/Unselect All}

$\square$ (3) Property Taxes

$\square$ (9) Sales, Use, and Lodging Taxes

$\square$ (2) Income Taxes 


\section{Enter Property Tax Rates}

\begin{tabular}{|c|c|c|c|c|}
\hline \multicolumn{5}{|l|}{ Clear } \\
\hline & \multicolumn{2}{|c|}{ Property Tax Rate (-) } & \multirow[b]{2}{*}{$\begin{array}{l}\% \text { of Value } \\
\text { (2.) Assessed }\end{array}$} & \multirow[b]{2}{*}{$\begin{array}{l}\text { Equalization Ratic } \\
\text { (9) }\end{array}$} \\
\hline Jurisdiction Name & Amount & Per & & \\
\hline San Luis Obipo & 1.0040 & $\$ 1,000$ & $100.00 \%$ & $94.00 \%$ \\
\hline Morro Bay & 1.0040 & $\$ 1,000$ & $100.00 \%$ & $94.00 \%$ \\
\hline Cambria & 1.0435 & $\$ 1,000$ & $100.00 \%$ & $94.00 \%$ \\
\hline Cayucos & 1.0550 & $\$ 1,000$ & $100.00 \%$ & $94.00 \%$ \\
\hline San Simeon & 1.0435 & $\$ 1,000$ & $100.00 \%$ & $94.00 \%$ \\
\hline \multicolumn{5}{|l|}{0} \\
\hline \multicolumn{5}{|l|}{$\overline{0}$} \\
\hline \multicolumn{5}{|l|}{0} \\
\hline \multicolumn{5}{|l|}{$\overline{0}$} \\
\hline \multicolumn{5}{|l|}{0} \\
\hline \multicolumn{5}{|l|}{0} \\
\hline \multicolumn{5}{|l|}{0} \\
\hline \multicolumn{5}{|l|}{0} \\
\hline \multicolumn{5}{|l|}{0} \\
\hline \multicolumn{5}{|l|}{0} \\
\hline 0 & & & & \\
\hline
\end{tabular}




\section{Enter Sales, Use, and Lodging Tax Rates}

\begin{tabular}{|c|c|c|c|c|c|}
\hline Reinstate Default Values & \multicolumn{5}{|c|}{ Cumulative Tax Rates } \\
\hline Jurisdiction Name & $\begin{array}{l}\text { General Sales } \\
\text { (6) and Use }\end{array}$ & (2) Groceries & $\begin{array}{l}\text { Prepared } \\
\text { Food }\end{array}$ & (2) Amusements & (2) Lodging \\
\hline SLO County & $8.00 \%$ & $0.00 \%$ & $8.00 \%$ & $0.00 \%$ & $9.50 \%$ \\
\hline 0 & $0.00 \%$ & $0.00 \%$ & $0.00 \%$ & $0.00 \%$ & $0.00 \%$ \\
\hline 0 & $0.00 \%$ & $0.00 \%$ & $0.00 \%$ & $0.00 \%$ & $0.00 \%$ \\
\hline 0 & $0.00 \%$ & $0.00 \%$ & $0.00 \%$ & $0.00 \%$ & $0.00 \%$ \\
\hline 0 & $0.00 \%$ & $0.00 \%$ & $0.00 \%$ & $0.00 \%$ & $0.00 \%$ \\
\hline$\overline{0}$ & $0.00 \%$ & $0.00 \%$ & $0.00 \%$ & $0.00 \%$ & $0.00 \%$ \\
\hline 0 & $0.00 \%$ & $0.00 \%$ & $0.00 \%$ & $0.00 \%$ & $0.00 \%$ \\
\hline 0 & $0.00 \%$ & $0.00 \%$ & $0.00 \%$ & $0.00 \%$ & $0.00 \%$ \\
\hline 0 & $0.00 \%$ & $0.00 \%$ & $0.00 \%$ & $0.00 \%$ & $0.00 \%$ \\
\hline 0 & $0.00 \%$ & $0.00 \%$ & $0.00 \%$ & $0.00 \%$ & $0.00 \%$ \\
\hline 0 & $0.00 \%$ & $0.00 \%$ & $0.00 \%$ & $0.00 \%$ & $0.00 \%$ \\
\hline 0 & $0.00 \%$ & $0.00 \%$ & $0.00 \%$ & $0.00 \%$ & $0.00 \%$ \\
\hline 0 & $0.00 \%$ & $0.00 \%$ & $0.00 \%$ & $0.00 \%$ & $0.00 \%$ \\
\hline 0 & $0.00 \%$ & $0.00 \%$ & $0.00 \%$ & $0.00 \%$ & $0.00 \%$ \\
\hline$\overline{0}$ & $0.00 \%$ & $0.00 \%$ & $0.00 \%$ & $0.00 \%$ & $0.00 \%$ \\
\hline 0 & $0.00 \%$ & $0.00 \%$ & $0.00 \%$ & $0.00 \%$ & $0.00 \%$ \\
\hline 0 & $0.00 \%$ & $0.00 \%$ & $0.00 \%$ & $0.00 \%$ & $0.00 \%$ \\
\hline 0 & $0.00 \%$ & $0.00 \%$ & $0.00 \%$ & $0.00 \%$ & $0.00 \%$ \\
\hline$\overline{0}$ & $0.00 \%$ & $0.00 \%$ & $0.00 \%$ & $0.00 \%$ & $0.00 \%$ \\
\hline
\end{tabular}




\section{Enter Income Tax Rates}

\begin{tabular}{|c|c|c|}
\hline Reinstate Default Values & & \\
\hline State & $\begin{array}{l}\text { Median Adjusted Gross } \\
\text { (9) Income }\end{array}$ & $\begin{array}{l}\text { Income Tax Rate for Median } \\
\text { Adjusted Gross Income } \\
\text { (9) Level }\end{array}$ \\
\hline California & 61,400 & $6.00 \%$ \\
\hline$\overline{0}$ & $\$$ & $0.00 \%$ \\
\hline 0 & $\$$ & $0.00 \%$ \\
\hline 0 & $\$$ & $0.00 \%$ \\
\hline 0 & $\$$ & $0.00 \%$ \\
\hline 0 & $\$$ & $0.00 \%$ \\
\hline 0 & $\$$ & $0.00 \%$ \\
\hline 0 & $\$$ & $0.00 \%$ \\
\hline 0 & $\$$ & $0.00 \%$ \\
\hline 0 & $\$$ & $0.00 \%$ \\
\hline 0 & $\$$ & $0.00 \%$ \\
\hline 0 & $\$$ & $0.00 \%$ \\
\hline 0 & $\$$ & $0.00 \%$ \\
\hline 0 & $\$$ & $0.00 \%$ \\
\hline 0 & $\$$ & $0.00 \%$ \\
\hline 0 & $\$$ & $0.00 \%$ \\
\hline 0 & $\$$ & $0.00 \%$ \\
\hline
\end{tabular}


No.

Investment Name

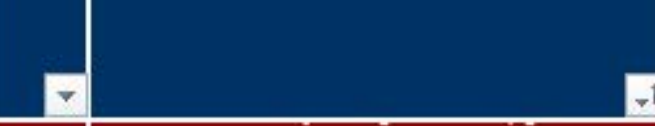

1.

(SHOPP)

Restorafion

3. Route 1 Rumble Strips (SHOPP)-NEW

4. Estero Bluffs

\begin{tabular}{l|l}
\hline 5. & Piedras Blancas Reaignment \\
\hline
\end{tabular}

6.$$
7 .
$$$$
+
$$

(5310)

Troley Purchase-COMPLETED

N. Main St. Bikepath-COMPLETED

$$
\underline{9}
$$

$+$

1

$\frac{1}{1}$

1
13. Route 1 Scenic Byway Corridor Plan Update

14. Highway 1 Community Gateway Monuments

15.

16

$\frac{1}{1}$

1

$\frac{1}{1}$

$\frac{1}{1}$

1

20

$\frac{21}{22}$

2

$\frac{2}{2}$

23

2

25

Route 1/SR 41 Interchange Improvement

\begin{tabular}{|l|r}
\hline Implementafio & $\$ 30,000$ \\
\hline
\end{tabular}

$\$ 390,000$

$\$ 25,000$

$\$ 385,000$

\begin{tabular}{|l|l}
\hline Upgrade & $\$ 36,000$ \\
\hline
\end{tabular}

Route 1 Chorro Valey Trai Study

$\$ 59,000$

$\$ 430,000$

$\$ 2,275,000$

\begin{tabular}{|c|c|}
\hline$\$ 133,411$ & $\$ 133,411$ \\
\hline$\$ 1,765,684$ & $\$ 1,765,684$ \\
\hline$\$ 421,136$ & $\$ 421,136$ \\
\hline$\$ 1,198,000$ & $\$ 1,198,000$ \\
\hline$\$ 200,000$ & $\$ 200,000$ \\
\hline$\$ 500,000$ & $\$ 500,000$ \\
\hline$\$ 405,000$ & $\$ 405,000$ \\
\hline
\end{tabular}

\begin{tabular}{|c|c|}
\hline$\$ 133,411$ & $\$ 133,411$ \\
\hline$\$ 1,765,684$ & $\$ 1,765,684$ \\
\hline$\$ 421,136$ & $\$ 421,136$ \\
\hline$\$ 1,198,000$ & $\$ 1,198,000$ \\
\hline$\$ 200,000$ & $\$ 200,000$ \\
\hline$\$ 500,000$ & $\$ 500,000$ \\
\hline$\$ 405,000$ & $\$ 405,000$ \\
\hline
\end{tabular}

(JARC)

\begin{tabular}{|c|c|}
\hline$\$ 133,411$ & $\$ 133,411$ \\
\hline$\$ 1,765,684$ & $\$ 1,765,684$ \\
\hline$\$ 421,136$ & $\$ 421,136$ \\
\hline$\$ 1,198,000$ & $\$ 1,198,000$ \\
\hline$\$ 200,000$ & $\$ 200,000$ \\
\hline$\$ 500,000$ & $\$ 500,000$ \\
\hline$\$ 405,000$ & $\$ 405,000$ \\
\hline
\end{tabular}

2005 Hardscape Enhancements

2005 Cayucos Old Creek Bridge Crossing

2005 Cayucos Scenic Viewshed Acquistion

2006 Byway and Interprefive Signs

Amount

Attributable

to Byway

Designation

Investment Type

$\$ 11,829,000$

$\$ 23,005,000$

$\$ 3,574,000$

$\$ 4,133,000$

$\$ 71,539,000$

$\$ 58,000$

$\$ 160,000$

$\$ 559,000$

$\$ 1,001,000$

\begin{tabular}{c|c}
$\$ 413,000$ & Capital Investment \\
$\$ 30,000$ & Operafing Expendture \\
\hline
\end{tabular}

$\$ \$ 390,000 \quad$ Capial Investment

\begin{tabular}{c|c|}
$\$ 390,000$ & Capital Investment \\
\hline$\$ 25,000$ & Operaing Expendture \\
\hline$\$ 385,000$ & Capital Investment \\
\hline
\end{tabular}

\begin{tabular}{c|c|}
\hline 46,000 & Capital Investment \\
\hline 59,000 & Operaing Expendture \\
\hline
\end{tabular}

\begin{tabular}{|c|c|}
\hline$\$ 430,000$ & Operaing Expendture \\
\hline$\$ 2,275,000$ & Capital Investment \\
\hline
\end{tabular}

\begin{tabular}{|c|c|}
\hline$\$ 133,411$ & Capital Investment \\
\hline$\$ 1,765,684$ & Captal Investment \\
\hline
\end{tabular}

Capital Investment

\begin{tabular}{l} 
Capital Investment \\
\hline Capital Investment \\
\hline Capital Investment \\
\hline Capital Investment \\
\hline
\end{tabular}




\section{Enter Economic Multiplier Data}

Geographic Area of Analysis

\section{Import Multipliers}

\begin{tabular}{|c|c|c|c|c|c|c|}
\hline Import Multipliers & & & & & \multicolumn{2}{|c|}{ Clear Multipliers } \\
\hline \multirow[b]{3}{*}{ Input Industry Group } & \multicolumn{6}{|c|}{ MULTIPLIERS } \\
\hline & \multicolumn{4}{|c|}{ Final-Demand } & \multicolumn{2}{|c|}{ Direct-Effect } \\
\hline & Output (\$) & Earnings (\$) & $\begin{array}{c}\text { Employment } \\
\text { (Jobs) }\end{array}$ & $\begin{array}{c}\text { Value-Added } \\
\text { (\$) }\end{array}$ & Earnings (\$) & $\begin{array}{c}\text { Employment } \\
\text { (Jobs) }\end{array}$ \\
\hline \multicolumn{7}{|l|}{ 62-INDUSTRY GROUP (3) } \\
\hline 1. Crop and animal production & 1.6607 & 0.2419 & 16.1318 & 0.6898 & 2.2470 & 1.4613 \\
\hline 2. Forestry, fishing, and related activities & 1.6616 & 0.4007 & 17.3859 & 0.8809 & 1.6748 & 1.5109 \\
\hline 3. Oil and gas extraction & 1.0000 & 0.0000 & 0.0000 & 0.0000 & 0.0000 & 0.0000 \\
\hline 4. Mining, except oil and gas & 1.7073 & 0.4417 & 9.4010 & 0.8993 & 1.7986 & 2.4735 \\
\hline 5. Support activities for mining & 1.8132 & 0.3421 & 8.2900 & 0.9162 & 3.5511 & 4.8424 \\
\hline 6. Utilities & 1.4447 & 0.2935 & 5.6090 & 0.8380 & 1.6982 & 3.1648 \\
\hline 7. Construction & 2.0860 & 0.6195 & 18.0935 & 1.0633 & 1.8813 & 1.9648 \\
\hline 8. Wood product manufacturing & 1.6765 & 0.3317 & 10.0230 & 0.6655 & 2.1384 & 2.0376 \\
\hline 9. Nonmetallic mineral product manufacturing & 1.8312 & 0.3841 & 9.2770 & 0.9255 & 2.2782 & 2.8058 \\
\hline 10. Primary metal manufacturing & 1.7661 & 0.4079 & 8.7611 & 0.6777 & 2.0231 & 2.8908 \\
\hline 11. Fabricated metal product manufacturing & 1.8633 & 0.4667 & 11.1512 & 0.9429 & 1.9539 & 2.3289 \\
\hline 12. Machinery manufacturing & 2.0119 & 0.4662 & 10.5876 & 0.9293 & 2.3166 & 2.9562 \\
\hline 13. Computer and electronic product manufacturing & 1.8995 & 0.4253 & 9.6238 & 0.8834 & 2.2775 & 2.9354 \\
\hline 14. Electrical equipment and appliance manufacturing & 1.9491 & 0.4092 & 9.2786 & 0.8789 & 2.5506 & 3.3027 \\
\hline 15. Motor vehicle, body, trailer, and parts manufacturing & 2.2003 & 0.4178 & 9.2894 & 0.7851 & 3.1257 & 4.7764 \\
\hline 16. Other transportation equipment manufacturing & 1.9332 & 0.4904 & 9.3761 & 0.8718 & 2.1018 & 3.6942 \\
\hline 17. Furniture and related product manufacturing & 1.8292 & 0.4151 & 11.6528 & 0.8850 & 2.0239 & 2.0467 \\
\hline 18. Miscellaneous manufacturing & 1.8347 & 0.4271 & 9.8142 & 0.9175 & 2.0118 & 2.5768 \\
\hline 19. Food, beverage, and tobacco product manufacturing & 1.9776 & 0.3075 & 9.3926 & 0.7802 & 3.2962 & 4.6543 \\
\hline 20. Textile and textile product mills & 1.6406 & 0.3100 & 8.5290 & 0.6308 & 2.0994 & 2.1876 \\
\hline 21. Apparel, leather, and allied product manufacturing & 1.7160 & 0.3148 & 10.2080 & 0.7467 & 2.4101 & 2.1802 \\
\hline 22. Paper manufacturing & 1.9910 & 0.3570 & 8.4712 & 0.8335 & 2.8674 & 3.6151 \\
\hline 23. Printing and related support activities & 2.0305 & 0.4263 & 10.9416 & 0.9674 & 2.2923 & 2.5087 \\
\hline 24. Petroleum and coal products manufacturing & 1.8569 & 0.4032 & 7.8572 & 0.5994 & 2.3856 & 4.7038 \\
\hline
\end{tabular}

Multi-County Region in:
View All Counties
ReSOurCe

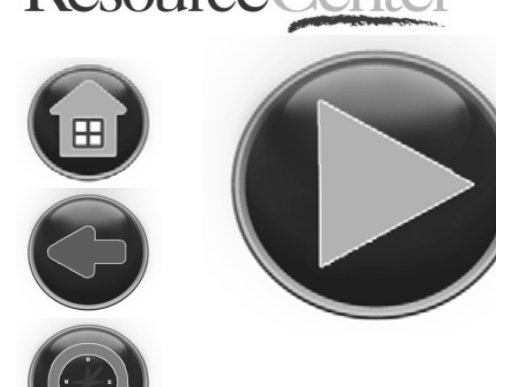




\begin{tabular}{|c|c|c|c|c|c|c|}
\hline 25. Chemical manufacturing & 1.7437 & 0.2656 & 5.7680 & 0.7443 & 3.4151 & 5.8925 \\
\hline 26. Plastics and rubber products manufacturing & 1.8728 & 0.3798 & 9.5591 & 0.8487 & 2.2344 & 2.5149 \\
\hline 27. Wholesale trade & 1.7912 & 0.5017 & 12.0013 & 1.1128 & 1.7890 & 2.2907 \\
\hline 28. Retail trade & 1.9050 & 0.5578 & 21.8494 & 1.1330 & 1.8383 & 1.5197 \\
\hline 29. Air transportation & 1.9075 & 0.5000 & 12.6128 & 0.9071 & 2.1313 & 3.6311 \\
\hline 30. Rail transportation & 1.7130 & 0.3757 & 8.4438 & 0.9729 & 2.1401 & 3.2718 \\
\hline 31. Water transportation & 1.0000 & 0.0000 & 0.0000 & 0.0000 & 0.0000 & 0.0000 \\
\hline 32. Truck transportation & 2.0193 & 0.5256 & 14.3982 & 1.0646 & 2.1314 & 2.3221 \\
\hline 33. Transit and ground passenger transportation & 2.0283 & 0.6630 & 37.8257 & 1.0723 & 1.7290 & 1.2942 \\
\hline 34. Pipeline transportation & 1.8325 & 0.4225 & 9.4334 & 0.8056 & 2.3148 & 4.0754 \\
\hline 35. Other transportation and support activities & 1.9076 & 0.6730 & 17.3226 & 1.2036 & 1.5903 & 1.8628 \\
\hline 36. Warehousing and storage & 1.8064 & 0.6285 & 18.6239 & 1.1713 & 1.4958 & 1.5970 \\
\hline 37. Publishing includustries, except Internet & 1.8268 & 0.4951 & 12.0731 & 1.0847 & 1.8025 & 2.1843 \\
\hline 38. Motion picture and sound recording industries & 1.6261 & 0.3446 & 14.9449 & 0.7802 & 1.9097 & 1.5457 \\
\hline 39. Broadcasting, except Internet & 1.7070 & 0.4007 & 9.4687 & 0.9364 & 1.8828 & 2.4407 \\
\hline 40. Telecommunications & 1.9741 & 0.7499 & 18.6500 & 1.2223 & 1.5547 & 1.9068 \\
\hline 41. Internet and other information services & 1.5395 & 0.3270 & 8.2190 & 1.0405 & 1.8232 & 2.3389 \\
\hline 42. Federal Reserve banks, credit intermediation and related se & 1.8919 & 0.7000 & 18.3275 & 1.0944 & 1.5561 & 1.7832 \\
\hline 43. Securities, commodity contracts, investments & 1.8509 & 0.4427 & 10.2321 & 0.9863 & 1.9610 & 2.4618 \\
\hline 44. Insurance carriers and related activities & 1.7569 & 0.3543 & 8.9016 & 0.5374 & 3.2315 & 3.4326 \\
\hline 45. Funds, trusts, and other financial vehicles & 1.2912 & 0.1049 & 4.2062 & 0.9248 & 3.3853 & 2.1895 \\
\hline 46. Real estate & 1.5490 & 0.3272 & 9.9765 & 1.1755 & 1.8278 & 1.9275 \\
\hline 47. Rental and leasing services and lessors of intangible assets & 1.8452 & 0.6469 & 15.6743 & 1.2011 & 1.5665 & 1.9853 \\
\hline 48. Professional, scientific, and technical services & 1.9234 & 0.7280 & 13.4580 & 1.2509 & 1.5147 & 2.4010 \\
\hline 49. Management of companies and enterprises & 1.7973 & 0.5982 & 24.7389 & 1.2061 & 1.5777 & 1.4200 \\
\hline 50. Administrative and support services & 1.9451 & 0.5198 & 13.5690 & 1.0695 & 1.9704 & 2.4424 \\
\hline 51. Waste management and remediation services & 1.9573 & 0.6620 & 27.7596 & 1.1334 & 1.5946 & 1.4307 \\
\hline 52. Educational services & 1.9482 & 0.7517 & 19.0606 & 1.2555 & 1.5327 & 1.8248 \\
\hline 53. Ambulatory health care services & 1.9973 & 0.7161 & 21.6019 & 1.1577 & 1.5915 & 1.7176 \\
\hline 54. Hospitals & 1.9900 & 0.6582 & 34.9432 & 1.1276 & 1.6517 & 1.3175 \\
\hline 55. Nursing and residential care facilities & 1.8436 & 0.5831 & 24.2142 & 1.0489 & 1.6677 & 1.4960 \\
\hline 56. Social assistance & 1.7967 & 0.5321 & 27.9934 & 1.1032 & 1.6551 & 1.3126 \\
\hline 57. Performing arts, museums, and related activities & 1.7143 & 0.4821 & 19.9090 & 1.0926 & 1.6626 & 1.4426 \\
\hline 58. Amusements, gambling, and recreation & 1.9342 & 0.5881 & 36.8447 & 1.0163 & 1.6228 & 1.2505 \\
\hline 59. Accommodation & 1.8933 & 0.5514 & 21.1634 & 1.0686 & 1.7322 & 1.5269 \\
\hline 60. Food services and drinking places & 1.1918 & 0.3219 & 11.2997 & 0.7034 & 0.0000 & 0.0000 \\
\hline \multicolumn{7}{|l|}{ 61. Other services } \\
\hline 62. Households & 1.5584 & 0.2169 & 11.0759 & 0.7857 & 2.2868 & 1.6106 \\
\hline 406-INDUSTRY GROUP (3) & 1.5422 & 0.2082 & 15.4123 & 0.7164 & 2.2535 & 1.4035 \\
\hline 1111C0 Oilseed and grain farming & 1.5018 & 0.2810 & 15.5345 & 0.8858 & 1.7723 & 1.3511 \\
\hline
\end{tabular}




\begin{tabular}{|c|c|c|c|c|c|c|}
\hline 111200 Vegetable and melon farming & 1.5732 & 0.3506 & 19.7517 & 0.8248 & 1.6874 & 1.3109 \\
\hline 1113B0 Fruit and tree nut farming & 1.5735 & 0.3668 & 24.5041 & 0.8998 & 1.6306 & 1.2403 \\
\hline 111400 Greenhouse, nursery, and floriculture production & 1.5574 & 0.4052 & 39.0948 & 1.0818 & 1.5474 & 1.1736 \\
\hline 111910 Tobacco farming & 1.4675 & 0.2553 & 13.8503 & 0.8422 & 1.8305 & 1.3695 \\
\hline 111920 Cotton farming & 1.0000 & 0.0000 & 0.0000 & 0.0000 & 0.0000 & 0.0000 \\
\hline $1119 \mathrm{C} 0$ All other crop farming, including sugarcane and sugar b & 1.6013 & 0.2951 & 15.6069 & 0.7041 & 1.9524 & 1.4239 \\
\hline $1121 \mathrm{~A} 0$ Cattle ranching and farming & 1.4774 & 0.2081 & 10.6542 & 0.7215 & 2.1345 & 1.5073 \\
\hline 112120 Dairy cattle and milk production & 2.0017 & 0.2765 & 20.0202 & 0.5579 & 2.9922 & 1.6883 \\
\hline 112A00 Animal production, except cattle and poultry and eggs & 2.0368 & 0.2869 & 15.8927 & 0.7370 & 3.0889 & 1.6872 \\
\hline 112300 Poultry and egg production & 2.2199 & 0.3099 & 18.5107 & 0.6514 & 3.3536 & 1.9044 \\
\hline $113 \mathrm{~A} 00$ Forest nurseries, forest products, and timber tracts & 1.0000 & 0.0000 & 0.0000 & 0.0000 & 0.0000 & 0.0000 \\
\hline 113300 Logging & 1.0000 & 0.0000 & 0.0000 & 0.0000 & 0.0000 & 0.0000 \\
\hline 114100 Fishing & 1.0000 & 0.0000 & 0.0000 & 0.0000 & 0.0000 & 0.0000 \\
\hline 114200 Hunting and trapping & 1.3149 & 0.1741 & 10.2092 & 0.6654 & 1.7328 & 1.4015 \\
\hline 115000 Support activities for agriculture and forestry & 2.0001 & 0.6447 & 33.1794 & 1.0755 & 1.6460 & 1.4342 \\
\hline 211000 Oil and gas extraction & 1.0000 & 0.0000 & 0.0000 & 0.0000 & 0.0000 & 0.0000 \\
\hline 212100 Coal mining & 1.0000 & 0.0000 & 0.0000 & 0.0000 & 0.0000 & 0.0000 \\
\hline 212210 Iron ore mining & 1.0000 & 0.0000 & 0.0000 & 0.0000 & 0.0000 & 0.0000 \\
\hline 2122A0 Gold, silver, and other metal ore mining & 1.0000 & 0.0000 & 0.0000 & 0.0000 & 0.0000 & 0.0000 \\
\hline 212230 Copper, nickel, lead, and zinc mining & 1.0000 & 0.0000 & 0.0000 & 0.0000 & 0.0000 & 0.0000 \\
\hline 212310 Stone mining and quarrying & 1.7164 & 0.4366 & 9.3820 & 0.9648 & 1.8570 & 2.5645 \\
\hline 212320 Sand, gravel, clay, and ceramic and refractory minerals & 1.7020 & 0.4453 & 10.1862 & 1.0032 & 1.7694 & 2.2233 \\
\hline 212390 Other nonmetallic mineral mining and quarrying & 1.0000 & 0.0000 & 0.0000 & 0.0000 & 0.0000 & 0.0000 \\
\hline 213111 Drilling oil and gas wells & 1.7839 & 0.3222 & 7.4578 & 0.8823 & 3.8058 & $\overline{4.1536}$ \\
\hline 213112 Support activities for oil and gas operations & 1.0000 & 0.0000 & 0.0000 & 0.0000 & 0.0000 & 0.0000 \\
\hline 21311A Support activities for other mining & 1.8379 & 0.3671 & 9.4429 & 0.8912 & 3.3857 & 6.1357 \\
\hline 2211A0 Electric power generation, transmission, and distribution & 1.4599 & 0.3059 & 5.7817 & 0.8992 & 1.6942 & 3.2775 \\
\hline 221200 Natural gas distribution & 1.3279 & 0.2109 & 4.1272 & 0.5275 & 1.7045 & 2.8827 \\
\hline 221300 Water, sewage and other systems & 1.6881 & 0.4243 & 9.9981 & 1.0488 & 1.8117 & 2.4304 \\
\hline 230000 Construction & 2.0850 & 0.6183 & 18.1984 & 1.0655 & 1.8779 & 1.9762 \\
\hline 311111 Dog and cat food manufacturing & 1.8061 & 0.2603 & 6.5635 & 0.5939 & 3.0571 & 5.1290 \\
\hline 311119 Other animal food manufacturing & 1.9509 & 0.2789 & 9.1993 & 0.5861 & 3.2756 & 4.7737 \\
\hline 311210 Flour milling and malt manufacturing & 2.2031 & 0.3238 & 12.1731 & 0.8003 & 3.8029 & 7.9823 \\
\hline 311221 Wet corn milling & 1.0000 & 0.0000 & 0.0000 & 0.0000 & 0.0000 & 0.0000 \\
\hline 31122A Soybean and other oilseed processing & 1.0000 & 0.0000 & 0.0000 & 0.0000 & 0.0000 & 0.0000 \\
\hline 311225 Fats and oils refining and blending & 2.1656 & 0.3148 & 11.3704 & 0.8151 & 3.6970 & 8.9357 \\
\hline 311230 Breakfast cereal manufacturing & 1.0000 & 0.0000 & 0.0000 & 0.0000 & 0.0000 & 0.0000 \\
\hline $31131 \mathrm{~A}$ Sugar cane mills and refining & 1.0000 & 0.0000 & 0.0000 & 0.0000 & 0.0000 & 0.0000 \\
\hline 311313 Beet sugar manufacturing & 1.0000 & 0.0000 & 0.0000 & 0.0000 & 0.0000 & 0.0000 \\
\hline 311320 Chocolate and confectionery manufacturing from cacao & 1.0000 & 0.0000 & 0.0000 & 0.0000 & 0.0000 & 0.0000 \\
\hline
\end{tabular}




\begin{tabular}{|c|c|c|c|c|c|c|}
\hline 311330 Confectionery manufacturing from purchased chocolate & 1.5709 & 0.2313 & 6.5345 & 0.4581 & 2.7159 & 2.6496 \\
\hline 311340 Nonchocolate confectionery manufacturing & 1.0000 & 0.0000 & 0.0000 & 0.0000 & 0.0000 & 0.0000 \\
\hline 311410 Frozen food manufacturing & 1.7272 & 0.2807 & 9.0997 & 0.8183 & 2.7918 & 2.1949 \\
\hline 311420 Fruit and vegetable canning, pickling, and drying & 1.0000 & 0.0000 & 0.0000 & 0.0000 & 0.0000 & 0.0000 \\
\hline 31151A Fluid milk and butter manufacturing & 1.8663 & 0.3204 & 8.3403 & 0.8220 & 3.0544 & 3.3929 \\
\hline 311513 Cheese manufacturing & 1.9273 & 0.3125 & 7.7848 & 0.8042 & 3.3622 & 4.1285 \\
\hline 311514 Dry, condensed, and evaporated dairy product manufac & 2.0856 & 0.2929 & 10.6474 & 0.5961 & 3.4022 & 6.0286 \\
\hline 311520 Ice cream and frozen dessert manufacturing & 1.0000 & 0.0000 & 0.0000 & 0.0000 & 0.0000 & 0.0000 \\
\hline 31161A Animal (except poultry) slaughtering, rendering, and pre & 1.0000 & 0.0000 & 0.0000 & 0.0000 & 0.0000 & 0.0000 \\
\hline 311615 Poultry processing & 1.8726 & 0.2623 & 7.7518 & 0.7476 & 3.0806 & 5.8826 \\
\hline 311700 Seafood product preparation and packaging & 2.0702 & 0.3318 & 9.3166 & 0.8151 & 3.2583 & 3.7345 \\
\hline 311810 Bread and bakery product manufacturing & 2.3476 & 0.3103 & 14.0128 & 0.5702 & 3.6445 & 6.0546 \\
\hline 311820 Cookie, cracker, and pasta manufacturing & 2.1195 & 0.3192 & 10.0508 & 0.6319 & 3.4103 & 4.3919 \\
\hline 311830 Tortilla manufacturing & 1.8951 & 0.2911 & 7.8328 & 0.7983 & 2.9397 & 3.2984 \\
\hline 311910 Snack food manufacturing & 1.0000 & 0.0000 & 0.0000 & 0.0000 & 0.0000 & 0.0000 \\
\hline 311920 Coffee and tea manufacturing & 1.7569 & 0.3296 & 9.0925 & 0.5890 & 2.6483 & 2.6410 \\
\hline 311930 Flavoring syrup and concentrate manufacturing & 1.7400 & 0.4086 & 12.0839 & 0.9696 & 1.8756 & 1.8897 \\
\hline 311940 Seasoning and dressing manufacturing & 1.0000 & 0.0000 & 0.0000 & 0.0000 & 0.0000 & 0.0000 \\
\hline 311990 All other food manufacturing & 1.7519 & 0.3343 & 8.6396 & 0.8936 & 2.4891 & 2.6082 \\
\hline 312110 Soft drink and ice manufacturing & 1.0000 & 0.0000 & 0.0000 & 0.0000 & 0.0000 & 0.0000 \\
\hline 312120 Breweries & 1.0000 & 0.0000 & 0.0000 & 0.0000 & 0.0000 & 0.0000 \\
\hline 312130 Wineries & 1.0000 & 0.0000 & 0.0000 & 0.0000 & 0.0000 & 0.0000 \\
\hline 312140 Distilleries & 1.6660 & 0.2404 & 6.7742 & 0.6367 & 2.8230 & 3.1299 \\
\hline 3122A0 Tobacco product manufacturing & 1.8564 & 0.3127 & 8.6851 & 0.8965 & 2.9464 & 3.5571 \\
\hline 313100 Fiber, yarn, and thread mills & 1.8069 & 0.2893 & 7.2928 & 0.5828 & 3.3974 & 3.7404 \\
\hline 313210 Broadwoven fabric mills & 1.0000 & 0.0000 & 0.0000 & 0.0000 & 0.0000 & 0.0000 \\
\hline 313220 Narrow fabric mills and schiffli machine embroidery & 1.8696 & 0.2862 & 7.2350 & 0.7795 & 3.3610 & 3.9318 \\
\hline 313230 Nonwoven fabric mills & 1.7464 & 0.3022 & 8.6801 & 0.9003 & 2.8842 & 5.7547 \\
\hline 313240 Knit fabric mills & 1.8332 & 0.3276 & 9.4252 & 0.7085 & 2.6966 & 2.9260 \\
\hline 313310 Textile and fabric finishing mills & 1.9566 & 0.3002 & 7.2506 & 0.7080 & 3.3453 & 4.5898 \\
\hline 313320 Fabric coating mills & 1.0000 & 0.0000 & 0.0000 & 0.0000 & 0.0000 & 0.0000 \\
\hline 314110 Carpet and rug mills & 1.6194 & 0.2620 & 8.9287 & 0.6669 & 2.7688 & 2.0421 \\
\hline 314120 Curtain and linen mills & 1.0000 & 0.0000 & 0.0000 & 0.0000 & 0.0000 & 0.0000 \\
\hline 314910 Textile bag and canvas mills & 1.0000 & 0.0000 & 0.0000 & 0.0000 & 0.0000 & 0.0000 \\
\hline 314990 All other textile product mills & 1.0000 & 0.0000 & 0.0000 & 0.0000 & 0.0000 & 0.0000 \\
\hline 315100 Apparel knitting mills & 1.0000 & 0.0000 & 0.0000 & 0.0000 & 0.0000 & 0.0000 \\
\hline 315210 Cut and sew apparel contractors & 1.0000 & 0.0000 & 0.0000 & 0.0000 & 0.0000 & 0.0000 \\
\hline 315220 Men's and boys' cut and sew apparel manufacturing & 1.6822 & 0.3669 & 10.7525 & 0.6559 & 1.9788 & 1.9660 \\
\hline 315230 Women's and girls' cut and sew apparel manufacturing & 1.0000 & 0.0000 & 0.0000 & 0.0000 & 0.0000 & 0.0000 \\
\hline 315290 Other cut and sew apparel manufacturing & 1.7459 & 0.3349 & 8.7957 & 0.7202 & 2.1686 & 2.3514 \\
\hline
\end{tabular}




\begin{tabular}{|c|c|c|c|c|c|c|}
\hline 315900 Apparel accessories and other apparel manufacturing & 1.0000 & 0.0000 & 0.0000 & 0.0000 & 0.0000 & 0.0000 \\
\hline 316100 Leather and hide tanning and finishing & 1.7498 & 0.3478 & 7.9457 & 0.6106 & 2.2305 & 3.1618 \\
\hline 316200 Footwear manufacturing & 1.7522 & 0.3576 & 8.5193 & 0.7978 & 2.1068 & 2.6264 \\
\hline 316900 Other leather and allied product manufacturing & 1.4999 & 0.2426 & 6.5918 & 0.5753 & 2.1720 & 2.3164 \\
\hline 321100 Sawmills and wood preservation & 1.6674 & 0.3292 & 9.9422 & 0.7258 & 2.0914 & 2.0052 \\
\hline $32121 \mathrm{~A}$ Veneer and plywood manufacturing & 1.7949 & 0.4706 & 13.8023 & 0.8135 & 1.8158 & 1.8177 \\
\hline 32121B Engineered wood member and truss manufacturing & 1.0000 & 0.0000 & 0.0000 & 0.0000 & 0.0000 & 0.0000 \\
\hline 321219 Reconstituted wood product manufacturing & 1.7758 & 0.4187 & 14.1506 & 0.7602 & 1.9409 & 1.7203 \\
\hline 321910 Wood windows and doors and millwork & 1.0000 & 0.0000 & 0.0000 & 0.0000 & 0.0000 & 0.0000 \\
\hline 321920 Wood container and pallet manufacturing & 1.0000 & 0.0000 & 0.0000 & 0.0000 & 0.0000 & 0.0000 \\
\hline 321991 Manufactured home (mobile home) manufacturing & 1.0000 & 0.0000 & 0.0000 & 0.0000 & 0.0000 & 0.0000 \\
\hline 321992 Prefabricated wood building manufacturing & 1.7138 & 0.3078 & 9.8594 & 0.7526 & 2.4395 & 2.1490 \\
\hline 321999 All other miscellaneous wood product manufacturing & 1.7182 & 0.3483 & 9.8607 & 0.7786 & 2.1751 & 2.2488 \\
\hline 322110 Pulp mills & 1.0000 & 0.0000 & 0.0000 & 0.0000 & 0.0000 & 0.0000 \\
\hline 322120 Paper mills & 1.0000 & 0.0000 & 0.0000 & 0.0000 & 0.0000 & 0.0000 \\
\hline 322130 Paperboard mills & 1.6348 & 0.3715 & 13.1392 & 0.8592 & 1.8742 & 1.5938 \\
\hline 322210 Paperboard container manufacturing & 1.4280 & 0.2181 & 6.9750 & 0.4868 & 2.0887 & 1.9365 \\
\hline 32222A Coated and laminated paper, packaging paper and plas & 1.5825 & 0.2251 & 6.7708 & 0.4338 & 2.9107 & 2.5721 \\
\hline 32222B All other paper bag and coated and treated paper mant & 1.0000 & 0.0000 & 0.0000 & 0.0000 & 0.0000 & 0.0000 \\
\hline 322230 Stationery product manufacturing & 1.6419 & 0.3233 & 9.4455 & 0.7269 & 2.0570 & 2.0626 \\
\hline 322291 Sanitary paper product manufacturing & 1.0000 & 0.0000 & 0.0000 & 0.0000 & 0.0000 & 0.0000 \\
\hline 322299 All other converted paper product manufacturing & 1.8056 & 0.3593 & 9.9829 & 0.7850 & 2.2308 & 2.3657 \\
\hline 323110 Printing & 1.5938 & 0.2760 & 8.8701 & 0.5784 & 2.2559 & 1.9984 \\
\hline 323120 Support activities for printing & 1.7046 & 0.3344 & 9.7129 & 0.6629 & 2.1669 & 2.1583 \\
\hline 324110 Petroleum refineries & 1.6263 & 0.3393 & 11.0943 & 0.6978 & 1.9664 & 1.7930 \\
\hline 324121 Asphalt paving mixture and block manufacturing & 1.0000 & 0.0000 & 0.0000 & 0.0000 & 0.0000 & 0.0000 \\
\hline 324122 Asphalt shingle and coating materials manufacturing & 1.7726 & 0.3526 & 10.1507 & 0.7095 & 2.2729 & 2.2629 \\
\hline 324191 Petroleum lubricating oil and grease manufacturing & 1.7475 & 0.3828 & 12.2744 & 0.8104 & 2.0214 & 1.8496 \\
\hline 324199 All other petroleum and coal products manufacturing & 1.6862 & 0.3196 & 8.1831 & 0.6615 & 2.3146 & 2.6563 \\
\hline 325110 Petrochemical manufacturing & 1.7212 & 0.2935 & 6.6973 & 0.7394 & 2.5875 & 3.7612 \\
\hline 325120 Industrial gas manufacturing & 2.1648 & 0.4075 & 9.6541 & 0.8692 & 2.7554 & 3.2003 \\
\hline 325130 Synthetic dye and pigment manufacturing & 2.0321 & 0.3458 & 7.9398 & 0.8791 & 3.1372 & 4.3825 \\
\hline 325181 Alkalies and chlorine manufacturing & 2.1890 & 0.4183 & 10.0517 & 0.8991 & 2.9129 & 3.3093 \\
\hline 325182 Carbon black manufacturing & 1.0000 & 0.0000 & 0.0000 & 0.0000 & 0.0000 & 0.0000 \\
\hline 325188 All other basic inorganic chemical manufacturing & 1.0000 & 0.0000 & 0.0000 & 0.0000 & 0.0000 & 0.0000 \\
\hline 325190 Other basic organic chemical manufacturing & 2.2062 & 0.4190 & 11.0518 & 0.9095 & 3.0540 & 2.8488 \\
\hline 325211 Plastics material and resin manufacturing & 1.0000 & 0.0000 & 0.0000 & 0.0000 & 0.0000 & 0.0000 \\
\hline 325212 Synthetic rubber manufacturing & 2.0983 & 0.3598 & 9.3422 & 0.8918 & 3.3518 & 3.1645 \\
\hline 325220 Artificial and synthetic fibers and filaments manufacturin & 1.0000 & 0.0000 & 0.0000 & 0.0000 & 0.0000 & 0.0000 \\
\hline 325310 Fertilizer manufacturing & 1.9906 & 0.3977 & 9.6459 & 0.9503 & 2.5925 & 2.9241 \\
\hline
\end{tabular}




\begin{tabular}{|c|c|c|c|c|c|c|}
\hline 325320 Pesticide and other agricultural chemical manufacturing & 2.0597 & 0.5008 & 13.2648 & 0.9831 & 2.0438 & 2.1618 \\
\hline 325411 Medicinal and botanical manufacturing & 1.9696 & 0.3892 & 8.9557 & 0.9712 & 2.3582 & 3.1317 \\
\hline 325412 Pharmaceutical preparation manufacturing & 1.9853 & 0.4916 & 12.7003 & 0.9846 & 1.9620 & 2.1331 \\
\hline 325413 In-vitro diagnostic substance manufacturing & 2.1563 & 0.4664 & 11.5480 & 0.9792 & 2.4775 & 2.9211 \\
\hline 325414 Biological product (except diagnostic) manufacturing & 2.0313 & 0.6224 & 19.7090 & 1.1555 & 1.7694 & 1.6632 \\
\hline 325510 Paint and coating manufacturing & 1.8275 & 0.5990 & 13.4815 & 1.0972 & 1.6246 & 2.0602 \\
\hline 325520 Adhesive manufacturing & 1.0000 & 0.0000 & 0.0000 & 0.0000 & 0.0000 & 0.0000 \\
\hline 325610 Soap and cleaning compound manufacturing & 1.8333 & 0.3494 & 7.4555 & 0.6472 & 3.0368 & 4.9499 \\
\hline 325620 Toilet preparation manufacturing & 1.8702 & 0.4652 & 9.3235 & 0.8318 & 2.0144 & 3.2189 \\
\hline 325910 Printing ink manufacturing & 1.8737 & 0.3945 & 8.0779 & 0.7027 & 2.3896 & 3.9990 \\
\hline 3259A0 All other chemical product and preparation manufacturi & 1.0000 & 0.0000 & 0.0000 & 0.0000 & 0.0000 & 0.0000 \\
\hline 326110 Plastics packaging materials and unlaminated film and & 1.0000 & 0.0000 & 0.0000 & 0.0000 & 0.0000 & 0.0000 \\
\hline 326121 Unlaminated plastics profile shape manufacturing & 1.6016 & 0.2562 & 5.3097 & 0.9126 & 3.1889 & 5.3906 \\
\hline 326122 Plastics pipe and pipe fitting manufacturing & 1.6822 & 0.2862 & 5.9687 & 0.7182 & 3.1609 & 5.4485 \\
\hline 326130 Laminated plastics plate, sheet (except packaging), and & 1.7122 & 0.2941 & 6.1766 & 0.8274 & 3.2714 & 5.7928 \\
\hline 326140 Polystyrene foam product manufacturing & 1.7498 & 0.2613 & 5.6764 & 0.6268 & 3.9669 & 8.5218 \\
\hline 326150 Urethane and other foam product (except polystyrene) & 1.6732 & 0.2273 & 4.9324 & 0.5823 & 3.7074 & 6.8751 \\
\hline 326160 Plastics bottle manufacturing & 1.6214 & 0.2424 & 5.2969 & 0.6901 & 3.2168 & 4.9075 \\
\hline 32619A Other plastics product manufacturing & 1.0000 & 0.0000 & 0.0000 & 0.0000 & 0.0000 & 0.0000 \\
\hline 326210 Tire manufacturing & 1.0000 & 0.0000 & 0.0000 & 0.0000 & 0.0000 & 0.0000 \\
\hline 326220 Rubber and plastics hoses and belting manufacturing & 1.4909 & 0.1971 & 4.1063 & 0.5629 & 3.2141 & 6.5298 \\
\hline 326290 Other rubber product manufacturing & 1.0000 & 0.0000 & 0.0000 & 0.0000 & 0.0000 & 0.0000 \\
\hline $32711 \mathrm{~A}$ Pottery, ceramics, and plumbing fixture manufacturing & 1.0000 & 0.0000 & 0.0000 & 0.0000 & 0.0000 & 0.0000 \\
\hline $32712 \mathrm{~A}$ Brick, tile, and other structural clay product manufacturi & 1.0000 & 0.0000 & 0.0000 & 0.0000 & 0.0000 & 0.0000 \\
\hline 32712B Clay and nonclay refractory manufacturing & 1.6080 & 0.2537 & 5.3653 & 0.7692 & 3.1031 & 5.4939 \\
\hline 327211 Flat glass manufacturing & 1.7709 & 0.2710 & 5.8383 & 0.7320 & 3.3202 & 5.4572 \\
\hline 327212 Other pressed and blown glass and glassware manufac & 1.7917 & 0.2828 & 6.2231 & 0.7596 & 3.3263 & 5.3962 \\
\hline 327213 Glass container manufacturing & 1.7470 & 0.2513 & 5.5318 & 0.7884 & 4.0986 & 7.4677 \\
\hline 327215 Glass product manufacturing made of purchased glass & 1.7385 & 0.2593 & 5.9087 & 0.8620 & 3.7801 & 5.5230 \\
\hline 327310 Cement manufacturing & 1.0000 & 0.0000 & 0.0000 & 0.0000 & 0.0000 & 0.0000 \\
\hline 327320 Ready-mix concrete manufacturing & 1.6948 & 0.2423 & 5.6079 & 0.8790 & 3.7370 & 5.5287 \\
\hline 327330 Concrete pipe, brick, and block manufacturing & 1.7213 & 0.2754 & 5.9185 & 0.6900 & 3.0833 & 4.7852 \\
\hline 327390 Other concrete product manufacturing & 1.0000 & 0.0000 & 0.0000 & 0.0000 & 0.0000 & 0.0000 \\
\hline 3274A0 Lime and gypsum product manufacturing & 1.8281 & 0.2773 & 6.3048 & 0.6878 & 3.0316 & 4.2429 \\
\hline 327910 Abrasive product manufacturing & 1.6666 & 0.2728 & 6.3519 & 0.8297 & 2.6216 & 3.5101 \\
\hline 327991 Cut stone and stone product manufacturing & 1.8225 & 0.2963 & 6.3751 & 0.7556 & 3.4654 & 6.2629 \\
\hline 327992 Ground or treated mineral and earth manufacturing & 1.8835 & 0.3296 & 7.7551 & 0.7887 & 2.5858 & 3.2627 \\
\hline 327993 Mineral wool manufacturing & 1.8696 & 0.3324 & 8.1885 & 0.7534 & 2.5326 & 2.8865 \\
\hline 327999 Miscellaneous nonmetallic mineral products & 1.9861 & 0.3877 & 9.7912 & 0.8984 & 2.5543 & 2.7489 \\
\hline 331110 Iron and steel mills and ferroalloy manufacturing & 1.8478 & 0.3266 & 8.4269 & 0.7803 & 2.4820 & 2.6877 \\
\hline
\end{tabular}




\begin{tabular}{|c|c|c|c|c|c|c|}
\hline 331200 Steel product manufacturing from purchased steel & 1.8667 & 0.3239 & 8.2497 & 0.8065 & 2.5061 & 2.8250 \\
\hline 33131A Alumina refining and primary aluminum production & 1.0000 & 0.0000 & 0.0000 & 0.0000 & 0.0000 & 0.0000 \\
\hline 331314 Secondary smelting and alloying of aluminum & 1.8909 & 0.3971 & 10.3022 & 0.8802 & 2.1518 & 2.3196 \\
\hline 33131B Aluminum product manufacturing from purchased alum & 1.6880 & 0.3384 & 7.7815 & 0.7189 & 2.1096 & 2.7897 \\
\hline 331411 Primary smelting and refining of copper & 1.7523 & 0.3527 & 8.5390 & 0.8285 & 2.1943 & 2.6287 \\
\hline 331419 Primary smelting and refining of nonferrous metal (exce & 1.8016 & 0.3842 & 9.7808 & 0.8357 & 2.1346 & 2.3773 \\
\hline 331420 Copper rolling, drawing, extruding and alloying & 1.0000 & 0.0000 & 0.0000 & 0.0000 & 0.0000 & 0.0000 \\
\hline 331490 Nonferrous metal (except copper and aluminum) rolling & 1.9717 & 0.5615 & 18.3275 & 1.0898 & 1.9159 & 1.6880 \\
\hline 331510 Ferrous metal foundries & 1.0000 & 0.0000 & 0.0000 & 0.0000 & 0.0000 & 0.0000 \\
\hline 331520 Nonferrous metal foundries & 1.0000 & 0.0000 & 0.0000 & 0.0000 & 0.0000 & 0.0000 \\
\hline 33211A All other forging, stamping, and sintering & 1.9426 & 0.4994 & 13.4318 & 0.9967 & 2.0392 & 2.0973 \\
\hline 332114 Custom roll forming & 2.0264 & 0.4544 & 11.1635 & 0.9550 & 2.4870 & 2.9689 \\
\hline 33211B Crown and closure manufacturing and metal stamping & 1.0000 & 0.0000 & 0.0000 & 0.0000 & 0.0000 & 0.0000 \\
\hline 33221A Cutlery, utensil, pot, and pan manufacturing & 1.0000 & 0.0000 & 0.0000 & 0.0000 & 0.0000 & 0.0000 \\
\hline 33221B Handtool manufacturing & 1.8060 & 0.3949 & 9.2918 & 0.9430 & 2.1118 & 2.6291 \\
\hline 332310 Plate work and fabricated structural product manufactur & 1.6739 & 0.2795 & 6.2638 & 0.9042 & 2.5453 & 3.6357 \\
\hline 332320 Ornamental and architectural metal products manufactc & 2.0344 & 0.4218 & 10.2985 & 0.9592 & 2.5188 & 2.9911 \\
\hline 332410 Power boiler and heat exchanger manufacturing & 1.9803 & 0.4683 & 11.4901 & 1.0161 & 2.1954 & 2.6062 \\
\hline 332420 Metal tank (heavy gauge) manufacturing & 1.9425 & 0.4596 & 11.2990 & 0.9896 & 2.1451 & 2.5289 \\
\hline 332430 Metal can, box, and other metal container (light gauge) & 1.9745 & 0.5025 & 12.8345 & 1.0410 & 2.0464 & 2.2542 \\
\hline 33299A Ammunition manufacturing & 1.0000 & 0.0000 & 0.0000 & 0.0000 & 0.0000 & 0.0000 \\
\hline 33299B Arms, ordnance, and accessories manufacturing & 1.0000 & 0.0000 & 0.0000 & 0.0000 & 0.0000 & 0.0000 \\
\hline 332500 Hardware manufacturing & 1.7298 & 0.3508 & 8.9797 & 0.9067 & 2.1652 & 2.4659 \\
\hline 332600 Spring and wire product manufacturing & 1.9421 & 0.5292 & 14.3046 & 1.0050 & 1.9523 & 2.0363 \\
\hline 332710 Machine shops & 1.5773 & 0.2957 & 6.7258 & 0.9747 & 2.0300 & 2.7325 \\
\hline 332720 Turned product and screw, nut, and bolt manufacturing & 1.7613 & 0.3709 & 8.2987 & 0.9291 & 2.0805 & 2.8954 \\
\hline 332800 Coating, engraving, heat treating and allied activities & 1.8313 & 0.3910 & 8.9493 & 0.9849 & 2.1958 & 2.8822 \\
\hline $33291 \mathrm{~A}$ Valve and fittings other than plumbing & 1.6719 & 0.3033 & 6.4026 & 0.6236 & 2.4199 & 4.3115 \\
\hline 332913 Plumbing fixture fitting and trim manufacturing & 1.0000 & 0.0000 & 0.0000 & 0.0000 & 0.0000 & 0.0000 \\
\hline 332991 Ball and roller bearing manufacturing & 1.5197 & 0.2680 & 5.9233 & 0.6446 & 2.0644 & 2.8898 \\
\hline 332996 Fabricated pipe and pipe fitting manufacturing & 1.6665 & 0.2644 & 5.9467 & 0.5531 & 2.7476 & 4.1162 \\
\hline 33299C Other fabricated metal manufacturing & 1.5895 & 0.3025 & 7.1154 & 0.7064 & 2.0805 & 2.5951 \\
\hline 333111 Farm machinery and equipment manufacturing & 1.0000 & 0.0000 & 0.0000 & 0.0000 & 0.0000 & 0.0000 \\
\hline 333112 Lawn and garden equipment manufacturing & 1.0000 & 0.0000 & 0.0000 & 0.0000 & 0.0000 & 0.0000 \\
\hline 333120 Construction machinery manufacturing & 1.0000 & 0.0000 & 0.0000 & 0.0000 & 0.0000 & 0.0000 \\
\hline 333130 Mining and oil and gas field machinery manufacturing & 1.5317 & 0.2307 & 4.8826 & 0.4579 & 2.6004 & 5.0806 \\
\hline 33329A Other industrial machinery manufacturing & 1.5434 & 0.2956 & 7.3699 & 0.5533 & 2.0099 & 2.3206 \\
\hline 333220 Plastics and rubber industry machinery manufacturing & 1.0000 & 0.0000 & 0.0000 & 0.0000 & 0.0000 & 0.0000 \\
\hline 333295 Semiconductor machinery manufacturing & 1.0000 & 0.0000 & 0.0000 & 0.0000 & 0.0000 & 0.0000 \\
\hline 33331A Vending, commercial, industrial, and office machinery n & 1.0000 & 0.0000 & 0.0000 & 0.0000 & 0.0000 & 0.0000 \\
\hline
\end{tabular}




\begin{tabular}{|c|c|c|c|c|c|c|}
\hline 333314 Optical instrument and lens manufacturing & 1.0000 & 0.0000 & 0.0000 & 0.0000 & 0.0000 & 0.0000 \\
\hline 333315 Photographic and photocopying equipment manufacturi & 1.0000 & 0.0000 & 0.0000 & 0.0000 & 0.0000 & 0.0000 \\
\hline 333319 Other commercial and service industry machinery mant & 1.0000 & 0.0000 & 0.0000 & 0.0000 & 0.0000 & 0.0000 \\
\hline 33341A Air purification and ventilation equipment manufacturing & 1.6820 & 0.3109 & 6.5921 & 0.5984 & 2.3603 & 3.8471 \\
\hline 333414 Heating equipment (except warm air furnaces) manufad & 1.0000 & 0.0000 & 0.0000 & 0.0000 & 0.0000 & 0.0000 \\
\hline 333415 Air conditioning, refrigeration, and warm air heating equ & 1.8575 & 0.4971 & 10.9605 & 0.9295 & 1.9103 & 2.5432 \\
\hline 333511 Industrial mold manufacturing & 1.8685 & 0.4789 & 11.7769 & 0.8383 & 1.9850 & 2.2919 \\
\hline $33351 \mathrm{~A}$ Metal cutting and forming machine tool manufacturing & 1.9147 & 0.4939 & 11.5037 & 0.9172 & 2.0042 & 2.4852 \\
\hline 333514 Special tool, die, jig, and fixture manufacturing & 1.7758 & 0.3974 & 9.2626 & 0.8695 & 2.0358 & 2.5562 \\
\hline 333515 Cutting tool and machine tool accessory manufacturing & 1.0000 & 0.0000 & 0.0000 & 0.0000 & 0.0000 & 0.0000 \\
\hline 33351B Rolling mill and other metalworking machinery manufad & 1.0000 & 0.0000 & 0.0000 & 0.0000 & 0.0000 & 0.0000 \\
\hline 333611 Turbine and turbine generator set units manufacturing & 1.8533 & 0.4574 & 11.4410 & 0.9127 & 1.9401 & 2.2150 \\
\hline 333612 Speed changer, industrial high-speed drive, and gear m & 1.0000 & 0.0000 & 0.0000 & 0.0000 & 0.0000 & 0.0000 \\
\hline 333613 Mechanical power transmission equipment manufacturi & 1.8432 & 0.4703 & 11.3876 & 0.9985 & 1.9151 & 2.2696 \\
\hline 333618 Other engine equipment manufacturing & 1.0000 & 0.0000 & 0.0000 & 0.0000 & 0.0000 & 0.0000 \\
\hline 333911 Pump and pumping equipment manufacturing & 1.9489 & 0.4151 & 10.7057 & 0.8791 & 2.5296 & 2.7516 \\
\hline 333912 Air and gas compressor manufacturing & 1.8570 & 0.3995 & 9.6314 & 0.7514 & 2.2161 & 2.7014 \\
\hline 333920 Material handling equipment manufacturing & 1.8026 & 0.3825 & 9.6522 & 0.8785 & 2.1235 & 2.4101 \\
\hline 333991 Power-driven handtool manufacturing & 1.7680 & 0.4681 & 10.9835 & 0.9505 & 1.7704 & 2.1684 \\
\hline 33399A Other general purpose machinery manufacturing & 1.7093 & 0.3675 & 9.4094 & 0.8193 & 1.9914 & 2.2160 \\
\hline 333993 Packaging machinery manufacturing & 1.7872 & 0.4480 & 11.1303 & 0.9365 & 1.8472 & 2.1201 \\
\hline 333994 Industrial process furnace and oven manufacturing & 1.7943 & 0.4378 & 11.1256 & 0.9089 & 1.9007 & 2.1318 \\
\hline 33399B Fluid power process machinery & 1.7651 & 0.4345 & 8.8086 & 0.9446 & 1.8587 & 2.8445 \\
\hline 334111 Electronic computer manufacturing & 1.7793 & 0.4297 & 10.0339 & 0.8995 & 1.9023 & 2.3721 \\
\hline 334112 Computer storage device manufacturing & 1.7973 & 0.2927 & 6.9436 & 0.6135 & 2.7054 & 3.5688 \\
\hline $33411 \mathrm{~A}$ Computer terminals and other computer peripheral equ & 1.0000 & 0.0000 & 0.0000 & 0.0000 & 0.0000 & 0.0000 \\
\hline 334210 Telephone apparatus manufacturing & 1.0000 & 0.0000 & 0.0000 & 0.0000 & 0.0000 & 0.0000 \\
\hline 334220 Broadcast and wireless communications equipment & 1.0000 & 0.0000 & 0.0000 & 0.0000 & 0.0000 & 0.0000 \\
\hline 334290 Other communications equipment manufacturing & 1.7955 & 0.4081 & 10.4209 & 0.9190 & 2.0239 & 2.2478 \\
\hline 334300 Audio and video equipment manufacturing & 1.7637 & 0.4189 & 10.4052 & 0.8973 & 1.9080 & 2.1987 \\
\hline 334411 Electron tube manufacturing & 2.0692 & 0.6364 & 15.7023 & 1.1216 & 1.9168 & 2.1610 \\
\hline 334412 Bare printed circuit board manufacturing & 1.7968 & 0.4818 & 11.7201 & 0.9885 & 1.8165 & 2.1563 \\
\hline 334413 Semiconductor and related device manufacturing & 1.7996 & 0.4241 & 10.3539 & 0.9634 & 1.9738 & 2.2913 \\
\hline 33441A Electronic capacitor, resistor, coil, transformer, and othe & 1.6849 & 0.3520 & 9.1274 & 0.8346 & 1.9499 & 2.1506 \\
\hline 334417 Electronic connector manufacturing & 1.9140 & 0.5698 & 14.9636 & 1.0780 & 1.7433 & 1.9106 \\
\hline 334418 Printed circuit assembly (electronic assembly) manufac & 1.7972 & 0.3989 & 9.1235 & 0.9699 & 2.0942 & 2.7280 \\
\hline 334419 Other electronic component manufacturing & 1.0000 & 0.0000 & 0.0000 & 0.0000 & 0.0000 & 0.0000 \\
\hline 334510 Electromedical and electrotherapeutic apparatus manuf & 1.7087 & 0.3880 & 9.6861 & 0.8654 & 1.9272 & 2.2098 \\
\hline 334511 Search, detection, and navigation instruments manufac & 1.9751 & 0.6839 & 16.3949 & 1.2119 & 1.6969 & 1.9671 \\
\hline 334512 Automatic environmental control manufacturing & 1.0000 & 0.0000 & 0.0000 & 0.0000 & 0.0000 & 0.0000 \\
\hline
\end{tabular}




\begin{tabular}{|c|c|c|c|c|c|c|}
\hline 334513 Industrial process variable instruments manufacturing & 1.9198 & 0.4502 & 11.0519 & 0.9437 & 2.1174 & 2.4990 \\
\hline 334514 Totalizing fluid meters and counting devices manufactu & 1.0000 & 0.0000 & 0.0000 & 0.0000 & 0.0000 & 0.0000 \\
\hline 334515 Electricity and signal testing instruments manufacturing & 1.0000 & 0.0000 & 0.0000 & 0.0000 & 0.0000 & 0.0000 \\
\hline 334516 Analytical laboratory instrument manufacturing & 2.0114 & 0.3875 & 9.3190 & 0.8273 & 2.9775 & 3.4369 \\
\hline 334517 Irradiation apparatus manufacturing & 1.0000 & 0.0000 & 0.0000 & 0.0000 & 0.0000 & 0.0000 \\
\hline 33451A Watch, clock, and other measuring and controlling devi & 1.0000 & 0.0000 & 0.0000 & 0.0000 & 0.0000 & 0.0000 \\
\hline 33461A Software, audio, and video media reproducing & 1.9817 & 0.4844 & 11.8682 & 0.9288 & 2.1934 & 2.5053 \\
\hline 334613 Magnetic and optical recording media manufacturing & 1.8614 & 0.4237 & 9.7153 & 0.9927 & 2.2003 & 2.7707 \\
\hline 335110 Electric lamp bulb and part manufacturing & 2.0287 & 0.4865 & 11.1343 & 0.9075 & 2.3066 & 2.9047 \\
\hline 335120 Lighting fixture manufacturing & 1.9448 & 0.4927 & 12.5425 & 1.0002 & 2.0840 & 2.2545 \\
\hline 335210 Small electrical appliance manufacturing & 2.0525 & 0.5104 & 11.3840 & 0.9577 & 2.2504 & 3.0352 \\
\hline 335221 Household cooking appliance manufacturing & 1.9823 & 0.4913 & 10.9731 & 0.9992 & 2.1651 & 2.8518 \\
\hline 335222 Household refrigerator and home freezer manufacturing & 1.0000 & 0.0000 & 0.0000 & 0.0000 & 0.0000 & 0.0000 \\
\hline 335224 Household laundry equipment manufacturing & 2.0387 & 0.4954 & 11.1529 & 0.9768 & 2.2424 & 2.9417 \\
\hline 335228 Other major household appliance manufacturing & 1.9712 & 0.4146 & 9.6326 & 0.8899 & 2.4708 & 3.0935 \\
\hline 335311 Power, distribution, and specialty transformer manufact & 1.8810 & 0.3618 & 9.9886 & 0.7947 & 2.6727 & 2.5231 \\
\hline 335312 Motor and generator manufacturing & 1.9311 & 0.4852 & 10.6294 & 0.9970 & 2.0530 & 2.7922 \\
\hline 335313 Switchgear and switchboard apparatus manufacturing & 1.0000 & 0.0000 & 0.0000 & 0.0000 & 0.0000 & 0.0000 \\
\hline 335314 Relay and industrial control manufacturing & 2.0511 & 0.4695 & 11.3609 & 0.8702 & 2.3726 & 2.7425 \\
\hline 335911 Storage battery manufacturing & 1.0000 & 0.0000 & 0.0000 & 0.0000 & 0.0000 & 0.0000 \\
\hline 335912 Primary battery manufacturing & 1.8860 & 0.4439 & 10.3516 & 0.9431 & 2.1254 & 2.6013 \\
\hline 335920 Communication and energy wire and cable manufacturi & 1.7198 & 0.3749 & 9.1805 & 0.9438 & 2.0163 & 2.3498 \\
\hline 335930 Wiring device manufacturing & 2.0400 & 0.4141 & 9.5393 & 0.8359 & 2.7684 & 3.6277 \\
\hline 335991 Carbon and graphite product manufacturing & 2.0227 & 0.6542 & 15.3758 & 1.1522 & 1.7755 & 2.1331 \\
\hline 335999 All other miscellaneous electrical equipment and compd & 2.0229 & 0.5060 & 11.3044 & 1.0143 & 2.2586 & 2.9227 \\
\hline 336111 Automobile manufacturing & 1.9052 & 0.4987 & 11.0598 & 1.0266 & 2.0138 & 2.6035 \\
\hline 336112 Light truck and utility vehicle manufacturing & 2.0554 & 0.6516 & 14.9143 & 1.1328 & 1.8580 & 2.2708 \\
\hline 336120 Heavy duty truck manufacturing & 1.8918 & 0.5359 & 12.4773 & 1.0224 & 1.9023 & 2.2928 \\
\hline 336211 Motor vehicle body manufacturing & 1.9671 & 0.4902 & 11.0624 & 0.9846 & 2.1553 & 2.7325 \\
\hline 336212 Truck trailer manufacturing & 1.8959 & 0.3834 & 7.8909 & 0.9814 & 2.5803 & 4.5222 \\
\hline 336213 Motor home manufacturing & 1.8809 & 0.4611 & 10.2780 & 0.9784 & 2.0771 & 2.6946 \\
\hline 336214 Travel trailer and camper manufacturing & 2.0310 & 0.3802 & 8.4898 & 0.8583 & 3.2848 & 4.7252 \\
\hline 336300 Motor vehicle parts manufacturing & 2.0145 & 0.4590 & 10.4809 & 0.9651 & 2.3702 & 3.0411 \\
\hline 336411 Aircraft manufacturing & 1.9469 & 0.4086 & 8.6636 & 0.9563 & 2.5188 & 3.9738 \\
\hline 336412 Aircraft engine and engine parts manufacturing & 2.0019 & 0.4400 & 11.8672 & 0.9076 & 2.5442 & 2.4933 \\
\hline 336413 Other aircraft parts and auxiliary equipment manufactur & 1.9701 & 0.4473 & 9.7461 & 0.8502 & 2.3256 & 3.2903 \\
\hline 336414 Guided missile and space vehicle manufacturing & 1.9192 & 0.4749 & 10.5818 & 0.9507 & 2.0725 & 2.7199 \\
\hline 33641A Propulsion units and parts for space vehicles and guide & 1.9707 & 0.4148 & 9.6953 & 0.8964 & 2.5225 & 3.1178 \\
\hline 336500 Railroad rolling stock manufacturing & 2.0731 & 0.4320 & 10.0999 & 0.8079 & 2.8161 & 3.4797 \\
\hline 336611 Ship building and repairing & 1.0000 & 0.0000 & 0.0000 & 0.0000 & 0.0000 & 0.0000 \\
\hline
\end{tabular}




\begin{tabular}{|c|c|c|c|c|c|c|}
\hline 336612 Boat building & 1.8747 & 0.4168 & 8.9772 & 0.8608 & 2.2195 & 3.1568 \\
\hline 336991 Motorcycle, bicycle, and parts manufacturing & 1.9660 & 0.5022 & 11.0604 & 1.0288 & 2.0640 & 2.7098 \\
\hline 336992 Military armored vehicle, tank, and tank component mar & 1.7835 & 0.4258 & 9.4834 & 0.9252 & 2.0147 & 2.6148 \\
\hline 336999 All other transportation equipment manufacturing & 1.8365 & 0.4640 & 11.1571 & 0.9748 & 1.9982 & 2.3615 \\
\hline 337110 Wood kitchen cabinet and countertop manufacturing & 1.9575 & 0.4752 & 10.3486 & 0.9807 & 2.2648 & 3.1151 \\
\hline 337121 Upholstered household furniture manufacturing & 1.9487 & 0.4782 & 10.4557 & 0.9847 & 2.1377 & 2.9321 \\
\hline 337122 Nonupholstered wood household furniture manufacturin & 1.0000 & 0.0000 & 0.0000 & 0.0000 & 0.0000 & 0.0000 \\
\hline 33712A Metal and other household furniture (except wood) mar & 1.0000 & 0.0000 & 0.0000 & 0.0000 & 0.0000 & 0.0000 \\
\hline 337127 Institutional furniture manufacturing & 1.0000 & 0.0000 & 0.0000 & 0.0000 & 0.0000 & 0.0000 \\
\hline 33721A Wood television, radio, and sewing machine cabinet $\mathrm{ma}$ & 2.0233 & 0.4463 & 10.2105 & 0.8103 & 2.5142 & 3.2973 \\
\hline 337212 Office furniture and custom architectural woodwork and & 1.0000 & 0.0000 & 0.0000 & 0.0000 & 0.0000 & 0.0000 \\
\hline 337215 Showcase, partition, shelving, and locker manufacturing & 1.8659 & 0.3995 & 8.7771 & 0.8534 & 2.2556 & 3.0753 \\
\hline 337910 Mattress manufacturing & 1.8931 & 0.4554 & 10.3877 & 0.9118 & 2.1343 & 2.7508 \\
\hline 337920 Blind and shade manufacturing & 2.1105 & 0.3889 & 9.2178 & 0.7346 & 3.4728 & 4.1471 \\
\hline 33911A Laboratory apparatus and surgical appliance and supp & 1.9510 & 0.4340 & 8.3686 & 0.8218 & 2.3563 & 4.8884 \\
\hline 339112 Surgical and medical instrument manufacturing & 1.5404 & 0.2778 & 6.1065 & 0.9386 & 2.2289 & 3.1446 \\
\hline 339114 Dental equipment and supplies manufacturing & 1.9513 & 0.4418 & 11.5314 & 0.8543 & 2.2508 & 2.3627 \\
\hline 339115 Ophthalmic goods manufacturing & 1.8858 & 0.4622 & 10.5094 & 0.8751 & 2.0484 & 2.6484 \\
\hline 339116 Dental laboratories & 1.9109 & 0.5445 & 11.5003 & 1.0363 & 1.8333 & 2.5443 \\
\hline 339910 Jewelry and silverware manufacturing & 1.0000 & 0.0000 & 0.0000 & 0.0000 & 0.0000 & 0.0000 \\
\hline 339920 Sporting and athletic goods manufacturing & 1.9736 & 0.5207 & 11.6667 & 1.0044 & 2.0789 & 2.9721 \\
\hline 339930 Doll, toy, and game manufacturing & 2.0691 & 0.4415 & 10.5493 & 0.9213 & 2.5230 & 2.9788 \\
\hline 339940 Office supplies (except paper) manufacturing & 1.7472 & 0.4117 & 9.8800 & 0.9409 & 1.9574 & 2.3237 \\
\hline 339950 Sign manufacturing & 2.1031 & 0.5560 & 13.6871 & 0.9981 & 2.2082 & 2.9312 \\
\hline 339991 Gasket, packing, and sealing device manufacturing & 1.0000 & 0.0000 & 0.0000 & 0.0000 & 0.0000 & 0.0000 \\
\hline 339992 Musical instrument manufacturing & 1.9364 & 0.5119 & 11.6336 & 0.9662 & 2.0109 & 2.5290 \\
\hline 33999A All other miscellaneous manufacturing & 1.0000 & 0.0000 & 0.0000 & 0.0000 & 0.0000 & 0.0000 \\
\hline 339994 Broom, brush, and mop manufacturing & 1.6646 & 0.3673 & 9.3734 & 0.9424 & 1.9161 & 2.1009 \\
\hline 420000 Wholesale trade & 1.0000 & 0.0000 & 0.0000 & 0.0000 & 0.0000 & 0.0000 \\
\hline 4A0000 Retail trade & 1.0000 & 0.0000 & 0.0000 & 0.0000 & 0.0000 & 0.0000 \\
\hline 481000 Air transportation & 1.9136 & 0.4005 & 9.5970 & 0.8633 & 2.6042 & 3.1577 \\
\hline 482000 Rail transportation & 1.9758 & 0.3628 & 8.6986 & 0.8752 & 3.1807 & 3.8638 \\
\hline 483000 Water transportation & 1.0000 & 0.0000 & 0.0000 & 0.0000 & 0.0000 & 0.0000 \\
\hline 484000 Truck transportation & 1.0000 & 0.0000 & 0.0000 & 0.0000 & 0.0000 & 0.0000 \\
\hline 485A00 Transit and ground passenger transportation & 2.1236 & 0.4186 & 10.9099 & 0.8410 & 2.9562 & 2.9460 \\
\hline 486000 Pipeline transportation & 1.0000 & 0.0000 & 0.0000 & 0.0000 & 0.0000 & 0.0000 \\
\hline 48A000 Scenic and sightseeing transportation and support activ & 1.9650 & 0.3538 & 8.7186 & 0.8247 & 3.1725 & 3.8023 \\
\hline 492000 Couriers and messengers & 1.8751 & 0.3819 & 8.3714 & 0.8322 & 2.5453 & 3.6976 \\
\hline 493000 Warehousing and storage & 1.9220 & 0.3990 & 9.0027 & 0.8704 & 2.5312 & 3.3418 \\
\hline 511110 Newspaper publishers & 1.8200 & 0.3873 & 8.9744 & 0.9430 & 2.3095 & 2.8178 \\
\hline
\end{tabular}




\begin{tabular}{|c|c|c|c|c|c|c|}
\hline 511120 Periodical publishers & 2.0956 & 0.4743 & 9.9870 & 0.9289 & 2.5141 & 3.9296 \\
\hline 511130 Book publishers & 1.7421 & 0.3535 & 8.0642 & 0.7557 & 2.3012 & 3.0602 \\
\hline 5111A0 Directory, mailing list, and other publishers & 1.0000 & 0.0000 & 0.0000 & 0.0000 & 0.0000 & 0.0000 \\
\hline 511200 Software publishers & 1.7847 & 0.3083 & 6.6148 & 0.8200 & 2.7194 & 4.7089 \\
\hline 512100 Motion picture and video industries & 1.6483 & 0.2670 & 6.5066 & 0.6591 & 2.4921 & 2.9960 \\
\hline 512200 Sound recording industries & 1.7654 & 0.3849 & 9.3890 & 0.9239 & 2.2127 & 2.5223 \\
\hline 515100 Radio and television broadcasting & 1.6610 & 0.3313 & 7.1883 & 0.9241 & 2.1485 & 3.0719 \\
\hline 515200 Cable and other subscription programming & 2.0455 & 0.4567 & 10.9566 & 0.8665 & 2.4445 & 2.8942 \\
\hline 51A000 Internet and other information services & 2.3272 & 0.4021 & 8.9774 & 0.7847 & 4.5276 & 10.0864 \\
\hline 517000 Telecommunications & 2.3286 & 0.3910 & 8.5710 & 0.7895 & 4.4020 & 7.3875 \\
\hline 52A000 Monetary authorities and depository credit intermediatic & 2.2227 & 0.4406 & 10.6958 & 0.8027 & 3.2009 & 3.7787 \\
\hline 522A00 Nondepository credit intermediation and related activitie & 1.0000 & 0.0000 & 0.0000 & 0.0000 & 0.0000 & 0.0000 \\
\hline 523000 Securities, commodity contracts, investments, and relat & 1.0000 & 0.0000 & 0.0000 & 0.0000 & 0.0000 & 0.0000 \\
\hline 524100 Insurance carriers & 2.0746 & 0.4364 & 11.0072 & 0.8381 & 2.4867 & 2.7965 \\
\hline 524200 Insurance agencies, brokerages, and related activities & 2.0255 & 0.4381 & 9.7895 & 0.8363 & 2.5435 & 3.5274 \\
\hline 525000 Funds, trusts, and other financial vehicles & 2.0924 & 0.4713 & 9.8156 & 0.8391 & 2.5491 & 3.8230 \\
\hline 531000 Real estate & 1.7929 & 0.3911 & 7.2078 & 0.8779 & 2.1651 & 4.2095 \\
\hline S00800 Owner-occupied dwellings & 2.0111 & 0.5473 & 11.1305 & 1.0207 & 2.0335 & 3.1164 \\
\hline 532100 Automotive equipment rental and leasing & 1.0000 & 0.0000 & 0.0000 & 0.0000 & 0.0000 & 0.0000 \\
\hline 532A00 General and consumer goods rental except video tapes & 1.8898 & 0.5662 & 12.7935 & 1.0269 & 1.7942 & 2.2160 \\
\hline 532230 Video tape and disc rental & 1.0000 & 0.0000 & 0.0000 & 0.0000 & 0.0000 & 0.0000 \\
\hline 532400 Commercial and industrial machinery and equipment re & 1.0000 & 0.0000 & 0.0000 & 0.0000 & 0.0000 & 0.0000 \\
\hline 533000 Lessors of nonfinancial intangible assets & 1.0000 & 0.0000 & 0.0000 & 0.0000 & 0.0000 & 0.0000 \\
\hline 541100 Legal services & 1.8702 & 0.4057 & 8.6558 & 0.7335 & 2.4076 & 3.6774 \\
\hline 541200 Accounting, tax preparation, bookkeeping, and payroll \$ & 1.0000 & 0.0000 & 0.0000 & 0.0000 & 0.0000 & 0.0000 \\
\hline 541300 Architectural, engineering, and related services & 1.9954 & 0.3506 & 8.4031 & 0.8729 & 3.2312 & 3.7188 \\
\hline 541400 Specialized design services & 1.7806 & 0.4129 & 11.8685 & 0.8693 & 1.9215 & 1.9599 \\
\hline 541511 Custom computer programming services & 1.9710 & 0.4479 & 12.7714 & 0.8175 & 2.1998 & 2.2250 \\
\hline 541512 Computer systems design services & 1.8397 & 0.4264 & 12.4794 & 0.8849 & 2.0401 & 1.9941 \\
\hline 54151A Other computer related services, including facilities ma & 1.0000 & 0.0000 & 0.0000 & 0.0000 & 0.0000 & 0.0000 \\
\hline 541610 Management, scientific, and technical consulting servic & 1.0000 & 0.0000 & 0.0000 & 0.0000 & 0.0000 & 0.0000 \\
\hline 5416A0 Environmental and other technical consulting services & 1.8648 & 0.4025 & 11.2549 & 0.8270 & 2.1050 & 2.1137 \\
\hline 541700 Scientific research and development services & 1.8256 & 0.4265 & 11.5867 & 0.9028 & 2.0010 & 2.1274 \\
\hline 541800 Advertising and related services & 1.7544 & 0.4824 & 12.9242 & 1.0074 & 1.7080 & 1.8541 \\
\hline 5419A0 All other miscellaneous professional, scientific, and tecl & 1.7633 & 0.3626 & 10.1509 & 0.8879 & 2.1408 & 2.1769 \\
\hline 541920 Photographic services & 1.7591 & 0.4231 & 11.4990 & 0.9231 & 1.8725 & 1.9857 \\
\hline 541940 Veterinary services & 2.0450 & 0.3870 & 10.1695 & 0.8892 & 2.9140 & 3.2370 \\
\hline 550000 Management of companies and enterprises & 1.0000 & 0.0000 & 0.0000 & 0.0000 & 0.0000 & 0.0000 \\
\hline 561300 Employment services & 1.0000 & 0.0000 & 0.0000 & 0.0000 & 0.0000 & 0.0000 \\
\hline 561500 Travel arrangement and reservation services & 1.7920 & 0.4236 & 8.8164 & 0.9904 & 2.0286 & 3.0474 \\
\hline
\end{tabular}




\begin{tabular}{|c|c|c|c|c|c|c|}
\hline 561100 Office administrative services & 1.7811 & 0.3926 & 8.6423 & 0.9526 & 2.1178 & 2.9098 \\
\hline 561200 Facilities support services & 1.0000 & 0.0000 & 0.0000 & 0.0000 & 0.0000 & 0.0000 \\
\hline 561400 Business support services & 1.8788 & 0.4550 & 11.7113 & 1.0516 & 2.1178 & 2.2939 \\
\hline 561600 Investigation and security services & 1.7341 & 0.5098 & 12.4612 & 0.9415 & 1.6475 & 1.9449 \\
\hline 561700 Services to buildings and dwellings & 1.6930 & 0.3569 & 8.4100 & 0.7293 & 2.1369 & 2.7409 \\
\hline 561900 Other support services & 1.9675 & 0.4117 & 10.4499 & 0.8437 & 2.5288 & 2.9410 \\
\hline 562000 Waste management and remediation services & 1.8674 & 0.3797 & 8.9505 & 0.9082 & 2.2960 & 2.9771 \\
\hline 611100 Elementary and secondary schools & 1.7971 & 0.3653 & 8.1634 & 0.9635 & 2.1861 & 2.9901 \\
\hline 611A00 Junior colleges, colleges, universities, and professional & 2.0568 & 0.5336 & 12.6058 & 0.9858 & 1.9706 & 2.4527 \\
\hline 611B00 Other educational services & 1.7978 & 0.4316 & 10.1344 & 0.9165 & 1.8794 & 2.3173 \\
\hline $621 \mathrm{~A} 00$ Offices of physicians, dentists, and other health practiti & 1.0000 & 0.0000 & 0.0000 & 0.0000 & 0.0000 & 0.0000 \\
\hline 621B00 Medical and diagnostic labs and outpatient and other al & 1.8161 & 0.4049 & 9.4902 & 0.9094 & 2.0562 & 2.6239 \\
\hline 621600 Home health care services & 1.0000 & 0.0000 & 0.0000 & 0.0000 & 0.0000 & 0.0000 \\
\hline 622000 Hospitals & 1.8909 & 0.4291 & 10.7886 & 0.9243 & 2.1065 & 2.4442 \\
\hline 623000 Nursing and residential care facilities & 1.7914 & 0.5022 & 12.0882 & 1.1123 & 1.7907 & 2.3073 \\
\hline 624A00 Individual and family services & 1.9078 & 0.5612 & 22.0430 & 1.1343 & 1.8494 & 1.5332 \\
\hline 624200 Community food, housing, and other relief services, inc & 1.9282 & 0.5018 & 12.3814 & 0.9012 & 2.1387 & 3.5645 \\
\hline 624400 Child day care services & 1.7211 & 0.3754 & 8.3304 & 0.9664 & 2.1384 & 3.2278 \\
\hline 711100 Performing arts companies & 1.0000 & 0.0000 & 0.0000 & 0.0000 & 0.0000 & 0.0000 \\
\hline 711200 Spectator sports & 2.0237 & 0.5252 & 14.3366 & 1.0614 & 2.1295 & 2.3122 \\
\hline $711 \mathrm{~A} 00$ Promoters of performing arts and sports and agents for & 2.0265 & 0.6642 & 37.9383 & 1.0748 & 1.7322 & 1.2980 \\
\hline 711500 Independent artists, writers, and performers & 1.8258 & 0.4191 & 9.6391 & 0.8041 & 2.2960 & 4.1642 \\
\hline 712000 Museums, historical sites, zoos, and parks & 2.0683 & 0.6651 & 16.0591 & 1.1232 & 1.8444 & 2.3168 \\
\hline 713A00 Amusement parks, arcades, and gambling industries & 1.7916 & 0.5528 & 17.9186 & 1.1216 & 1.6375 & 1.6515 \\
\hline 713B00 Other amusement and recreation industries & 1.8126 & 0.6326 & 18.8367 & 1.1738 & 1.5057 & 1.6152 \\
\hline 713940 Fitness and recreational sports centers & 1.9094 & 0.5884 & 15.6657 & 1.1528 & 1.7160 & 1.8457 \\
\hline 713950 Bowling centers & 1.8813 & 0.4690 & 11.2013 & 1.0444 & 1.9669 & 2.4278 \\
\hline 7211A0 Hotels and motels, including casino hotels & 1.7656 & 0.3952 & 9.1614 & 0.9042 & 2.0663 & 2.7355 \\
\hline 721A00 Other accommodations & 1.7055 & 0.3830 & 9.1263 & 1.0468 & 1.9371 & 2.4104 \\
\hline 722000 Food services and drinking places & 1.7811 & 0.5550 & 11.6177 & 1.1320 & 1.6487 & 2.6522 \\
\hline $8111 \mathrm{~A} 0$ Automotive repair and maintenance, except car washes & 1.6608 & 0.4029 & 18.3970 & 0.7547 & 1.7906 & 1.4725 \\
\hline 811192 Car washes & 1.5912 & 0.2794 & 8.7473 & 0.9394 & 2.2364 & 2.2052 \\
\hline 811200 Electronic and precision equipment repair and maintens & 1.8515 & 0.5033 & 11.4410 & 0.7969 & 1.8490 & 2.5724 \\
\hline 811300 Commercial and industrial machinery and equipment re & 1.7772 & 0.4028 & 10.3925 & 0.9145 & 1.9663 & 2.3478 \\
\hline 811400 Personal and household goods repair and maintenance & 1.6497 & 0.3753 & 8.7040 & 0.9452 & 1.8789 & 2.5501 \\
\hline 812100 Personal care services & 2.0040 & 0.7742 & 19.2851 & 1.1927 & 1.5528 & 1.9163 \\
\hline 812200 Death care services & 1.8835 & 0.6751 & 17.2180 & 1.1871 & 1.5794 & 1.9253 \\
\hline 812300 Dry-cleaning and laundry services & 1.5141 & 0.3202 & 8.1229 & 1.0391 & 1.7880 & 2.3179 \\
\hline 812900 Other personal services & 1.6122 & 0.3531 & 8.9898 & 1.0471 & 1.9604 & 2.5429 \\
\hline 813100 Religious organizations & 1.8954 & 0.7025 & 18.4600 & 1.0947 & 1.5616 & 1.7961 \\
\hline
\end{tabular}




\begin{tabular}{|c|c|c|c|c|c|c|}
\hline $813 \mathrm{~A} 00$ Grantmaking, giving, and social advocacy organizations & 1.8981 & 0.4452 & 10.2487 & 0.9809 & 2.1655 & 2.9339 \\
\hline 813B00 Civic, social, professional, and similar organizations & 1.5997 & 0.4369 & 11.1845 & 1.1367 & 1.6055 & 1.8858 \\
\hline 491000 Postal service & 1.7555 & 0.3565 & 9.0170 & 0.5403 & 3.2520 & 3.4770 \\
\hline S00A00 Other government enterprises & 1.4642 & 0.2202 & 10.2057 & 0.9770 & 2.3056 & 1.7234 \\
\hline \multirow[t]{36}{*}{ H00000 Households } & 1.2175 & 0.0539 & 1.6387 & 0.9311 & 0.0000 & 0.0000 \\
\hline & 1.5736 & 0.3070 & 8.9309 & 1.0228 & 2.0605 & 2.3358 \\
\hline & 1.7189 & 0.4825 & 15.1403 & 1.1144 & 1.6936 & 1.7560 \\
\hline & 1.5789 & 0.3573 & 20.5925 & 0.9818 & 1.7347 & 1.3037 \\
\hline & 1.5222 & 0.3228 & 8.1406 & 1.0509 & 1.8029 & 2.4067 \\
\hline & 1.1394 & 0.1318 & 2.4581 & 1.0478 & 1.3958 & 2.0799 \\
\hline & 1.9196 & 0.7721 & 16.4350 & 1.2775 & 1.4873 & 2.0868 \\
\hline & 1.8858 & 0.7358 & 22.7074 & 1.2624 & 1.4980 & 1.5735 \\
\hline & 1.8362 & 0.6500 & 17.2241 & 1.2165 & 1.5844 & 1.8899 \\
\hline & 1.8223 & 0.5789 & 19.7806 & 1.1433 & 1.6698 & 1.6362 \\
\hline & 1.8811 & 0.7336 & 15.3527 & 1.2286 & 1.5073 & 2.2702 \\
\hline & 1.9279 & 0.7508 & 16.5942 & 1.2522 & 1.5427 & 2.2196 \\
\hline & 1.7217 & 0.4565 & 11.3443 & 1.0311 & 1.8185 & 2.5171 \\
\hline & 1.8927 & 0.7098 & 22.0339 & 1.2417 & 1.5346 & 1.6595 \\
\hline & 1.7654 & 0.5890 & 20.0904 & 1.1973 & 1.5785 & 1.5851 \\
\hline & 1.8846 & 0.6450 & 13.6752 & 1.1569 & 1.5984 & 2.4089 \\
\hline & 1.7982 & 0.5675 & 14.7579 & 1.1152 & 1.6376 & 1.9987 \\
\hline & 1.8011 & 0.5669 & 14.2644 & 1.1163 & 1.6369 & 2.0472 \\
\hline & 1.9456 & 0.6338 & 14.0972 & 1.0452 & 1.6727 & 2.4343 \\
\hline & 1.4481 & 0.2893 & 6.1022 & 1.0489 & 1.7941 & 3.3078 \\
\hline & 1.9283 & 0.7324 & 13.6108 & 1.2506 & 1.5237 & 2.4282 \\
\hline & 1.7152 & 0.6859 & 32.8964 & 1.3307 & 1.4132 & 1.2536 \\
\hline & 2.0044 & 0.6322 & 21.3617 & 1.1431 & 1.8483 & 1.7014 \\
\hline & 1.8405 & 0.6525 & 16.9065 & 1.2298 & 1.5812 & 1.9524 \\
\hline & 1.7464 & 0.6247 & 21.1677 & 1.2405 & 1.5050 & 1.5174 \\
\hline & 1.7254 & 0.5162 & 18.1280 & 1.1381 & 1.6560 & 1.6004 \\
\hline & 1.8229 & 0.7159 & 32.4238 & 1.2966 & 1.4750 & 1.3111 \\
\hline & 1.9374 & 0.5886 & 28.2472 & 1.1456 & 1.7817 & 1.5430 \\
\hline & 1.7081 & 0.4598 & 14.1918 & 1.1142 & 1.7300 & 1.8039 \\
\hline & 1.9402 & 0.5189 & 13.3416 & 1.0706 & 1.9672 & 2.4015 \\
\hline & 2.0071 & 0.7103 & 32.8223 & 1.1536 & 1.5744 & 1.3754 \\
\hline & 2.0109 & 0.7159 & 27.7399 & 1.1517 & 1.5688 & 1.4853 \\
\hline & 1.8151 & 0.5081 & 26.3112 & 1.0841 & 1.8076 & 1.4039 \\
\hline & 1.9227 & 0.7680 & 17.5480 & 1.2888 & 1.4995 & 1.9528 \\
\hline & 1.9664 & 0.7874 & 31.5994 & 1.2731 & 1.5221 & 1.3968 \\
\hline & 2.0371 & 0.6945 & 20.2038 & 1.1363 & 1.7193 & 1.8914 \\
\hline
\end{tabular}




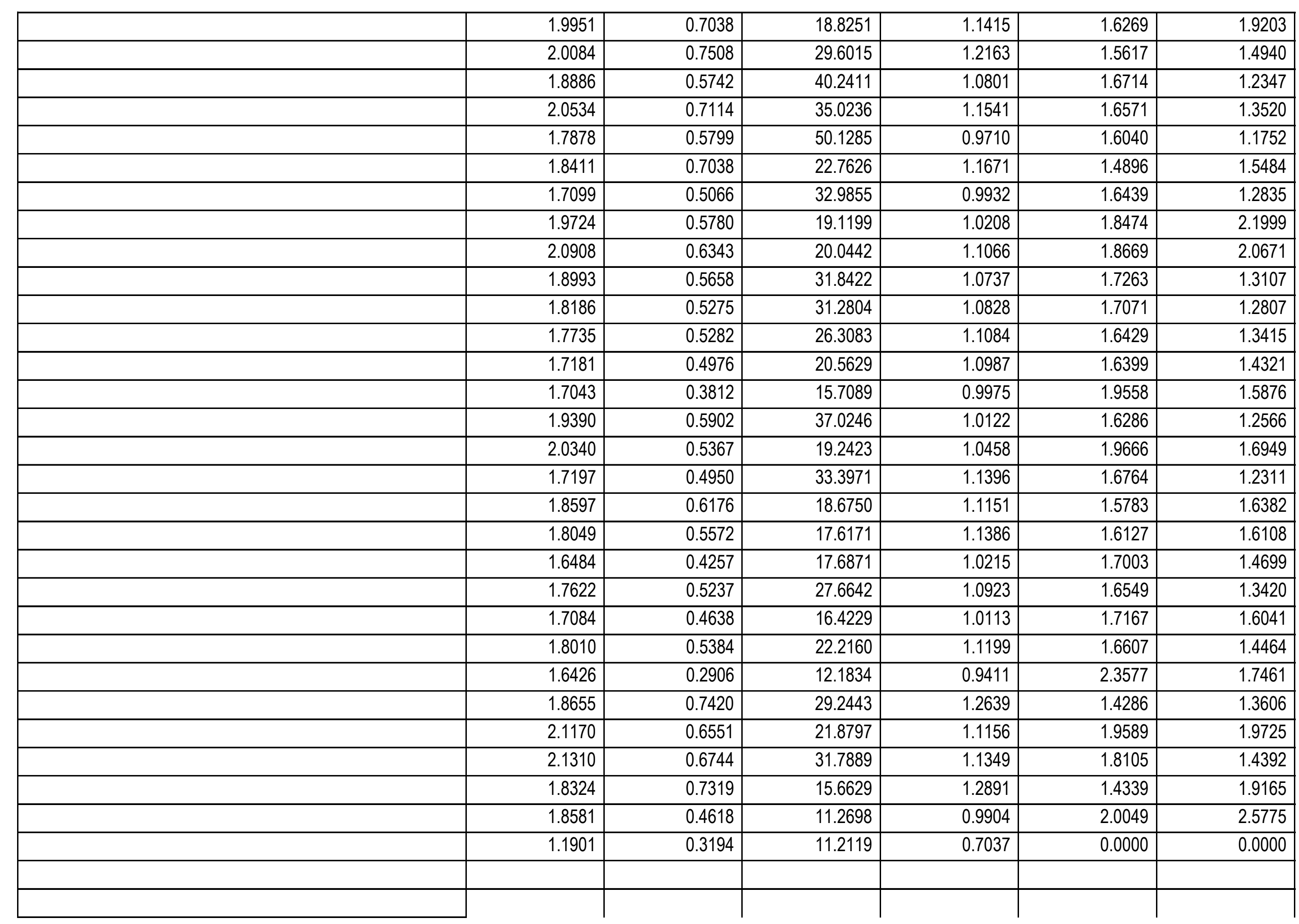




\section{RESULTS NAVIGATOR: Impact Analysis Outcomes}

\begin{tabular}{|c|}
\hline to View Data Summary \\
\hline to View Summary of All Economic Impacts \\
\hline to View Total Visitor Spending Impacts \\
\hline to View Other Economic Output Results \\
\hline to View Employment Impact Results \\
\hline to View Earnings Impact Results \\
\hline to View Tax Impact Results \\
\hline to View Impact Results by Intrinsic Quality \\
\hline
\end{tabular}

ResOurce Resource

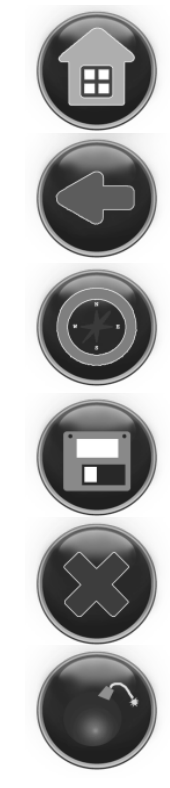




\section{Data Summary}

Name of Byway: Name of Analysis

Geographic Area of Analysis

Time Frame

Visitor Counts

Total Visitor Spending Total Annual Spending in Region

Capital Investments Attributable to Designation

Ongoing Operating Expenditures Attributable to Designation
BCP: Update

Multi-County Region in:

View All Counties

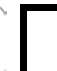

Base Year

2006

Current Year Net Change

$5,399,000$

\$

$500,302,900.00$

$6,498,000$
2012

$645,950,000.00$

$\$ \quad 145,647,100.00$

$\$ \quad 124,534,231$

$\$ \quad 544,000$




\section{Summary of Visitation to Region}

\begin{tabular}{|c|c|c|c|}
\hline & Base Year & Current Year & Net Change \\
\hline Total Visitation & $5,399,000$ & $6,498,000$ & $1,099,000$ \\
\hline Total Travel Parties & $1,542,571$ & $1,856,571$ & 314,000 \\
\hline Total Person Days in Region & $10,798,000$ & $12,996,000$ & $2,198,000$ \\
\hline Total Party Days in Region & $3,085,143$ & $3,713,143$ & 628,000 \\
\hline Overnight Visitors & $4,319,200$ & $5,198,400$ & 879,200 \\
\hline Daytrippers & $1,889,650$ & $2,274,300$ & 384,650 \\
\hline Overnight Parties & $1,234,057$ & $1,485,257$ & 251,200 \\
\hline Daytrip Parties & 539,900 & 649,800 & 109,900 \\
\hline Person-Nights Stayed & $8,638,400$ & $10,396,800$ & $1,758,400$ \\
\hline Party-Nights Stayed & $1,079,800$ & $1,299,600$ & 219,800 \\
\hline Person-Nights in Hotels/Motels & $7,774,560$ & $9,357,120$ & $1,582,560$ \\
\hline Person-Nights with Friends/Relatives & 863,840 & $1,039,680$ & 175,840 \\
\hline Party-Nights in Hotels/Motels & 971,820 & $1,169,640$ & 197,820 \\
\hline Party-Nights with Friends/Relatives & 107,980 & 129,960 & 21,980 \\
\hline
\end{tabular}




\section{Overall Economic Impact Summary}

Name of Analysis

Geographic Area of Analysis

BCP: Update

\begin{tabular}{|c|c|}
\hline \multicolumn{2}{|c|}{ Multi-County Region in: } \\
\hline Base Year & Current Year \\
\hline 2006 & 2012 \\
\hline
\end{tabular}

View All Counties

Analysis Period

\begin{tabular}{|l|l|l|}
\hline DIRECT IMPACTS & INDIRECT IMPACTS & TOTAL IMPACTS \\
\hline
\end{tabular}

\begin{tabular}{|r|c|r|r|}
\cline { 2 - 4 } \multicolumn{1}{c|}{} & DIRECT IMPACTS & INDIRECT IMPACTS & TOTAL IMPACTS \\
\hline Employment (No. of Jobs) & \#DIV/0! & \#DIV/0! & 2,316 \\
\hline Earnings $\mathbf{( \$ 0 0 0 )}$ & \#DIV/0! & \#DIV/0! & $\$$ \\
\hline Economic Output $\mathbf{\$ 0 0 0 )}$ & & & $51,064.4$ \\
\hline Visitor Spending & $\$ 145,647.1$ & $\$ 11,304.5$ & $\$$ \\
\hline Annual Operating Expenses & 544.0 & 326.2 & $216,951.6$ \\
\hline Capital Investments to Date & $123,990.2$ & $74,356.9$ & 870.2 \\
\hline Property Value Appreciation & $89,463.7$ & $\mathrm{NA}$ & NA \\
\hline
\end{tabular}

View Summary

Tax Impacts (Direct \& Indirect Total, Values in \$000)

\begin{tabular}{|l|r|rr|}
\hline & Minimum Amount & Maximum Amount \\
\hline Property Taxes & $\$$ & 84.4 & $\$$ \\
\hline Sales, Use, and Lodging Taxes & $10,437.4$ & 88.7 \\
\hline Income Taxes & $3,063.9$ & $10,437.4$ \\
\hline
\end{tabular}




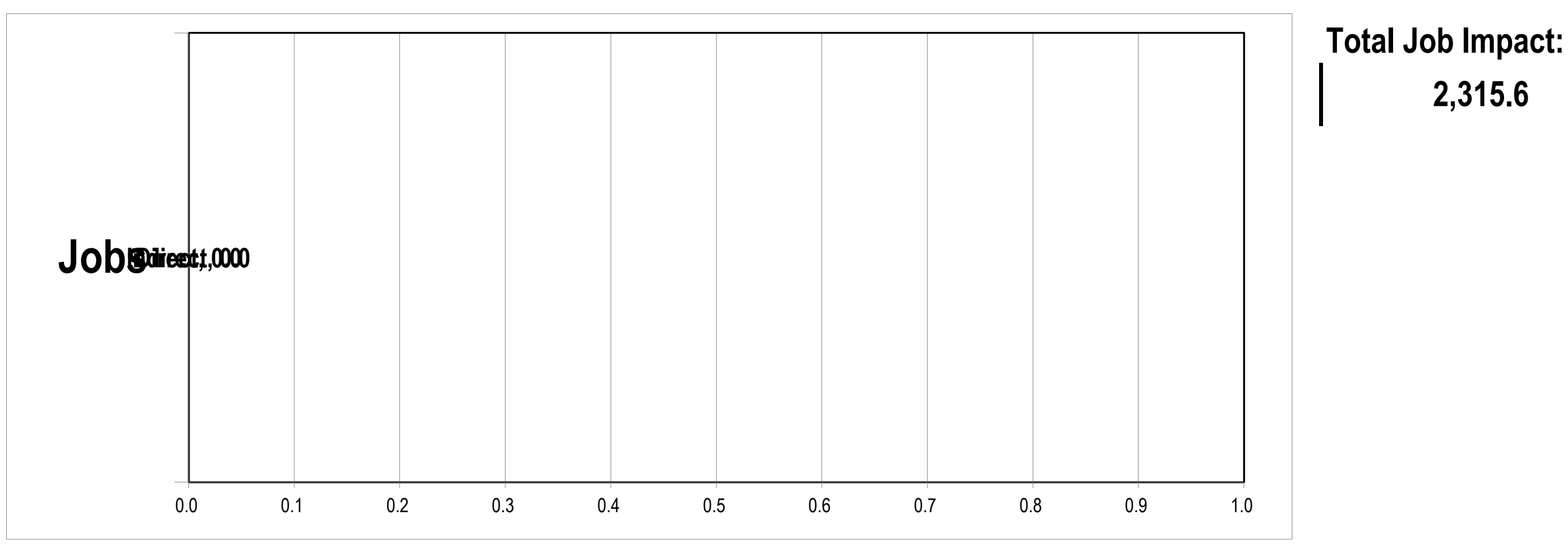




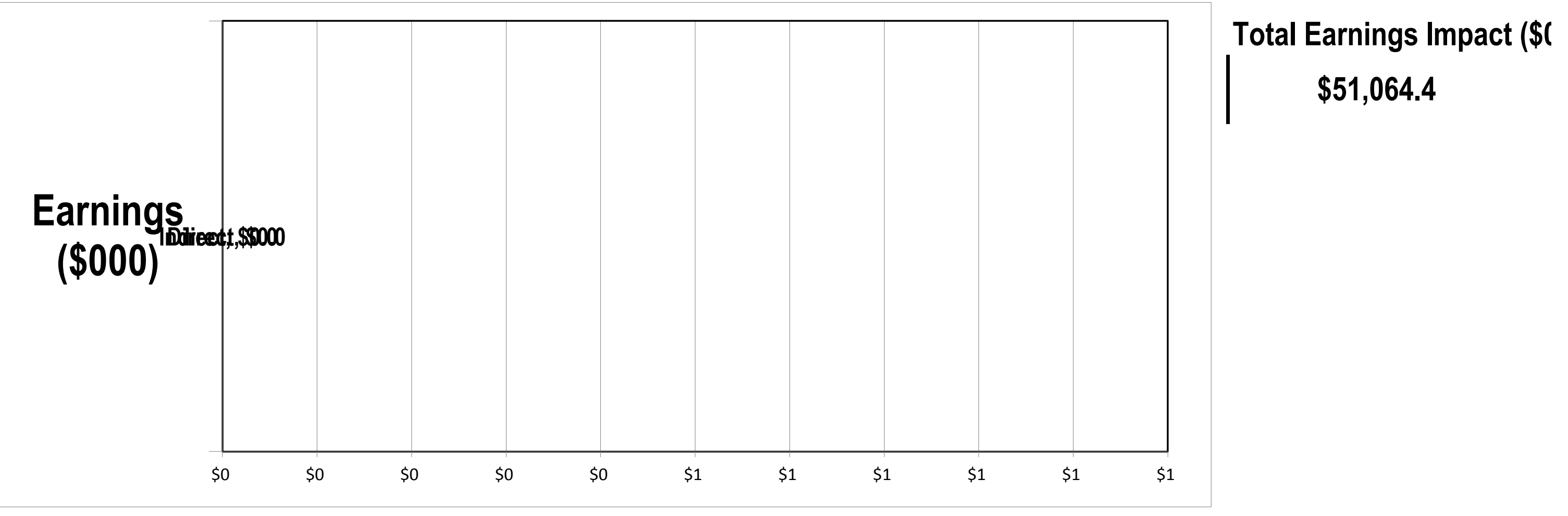




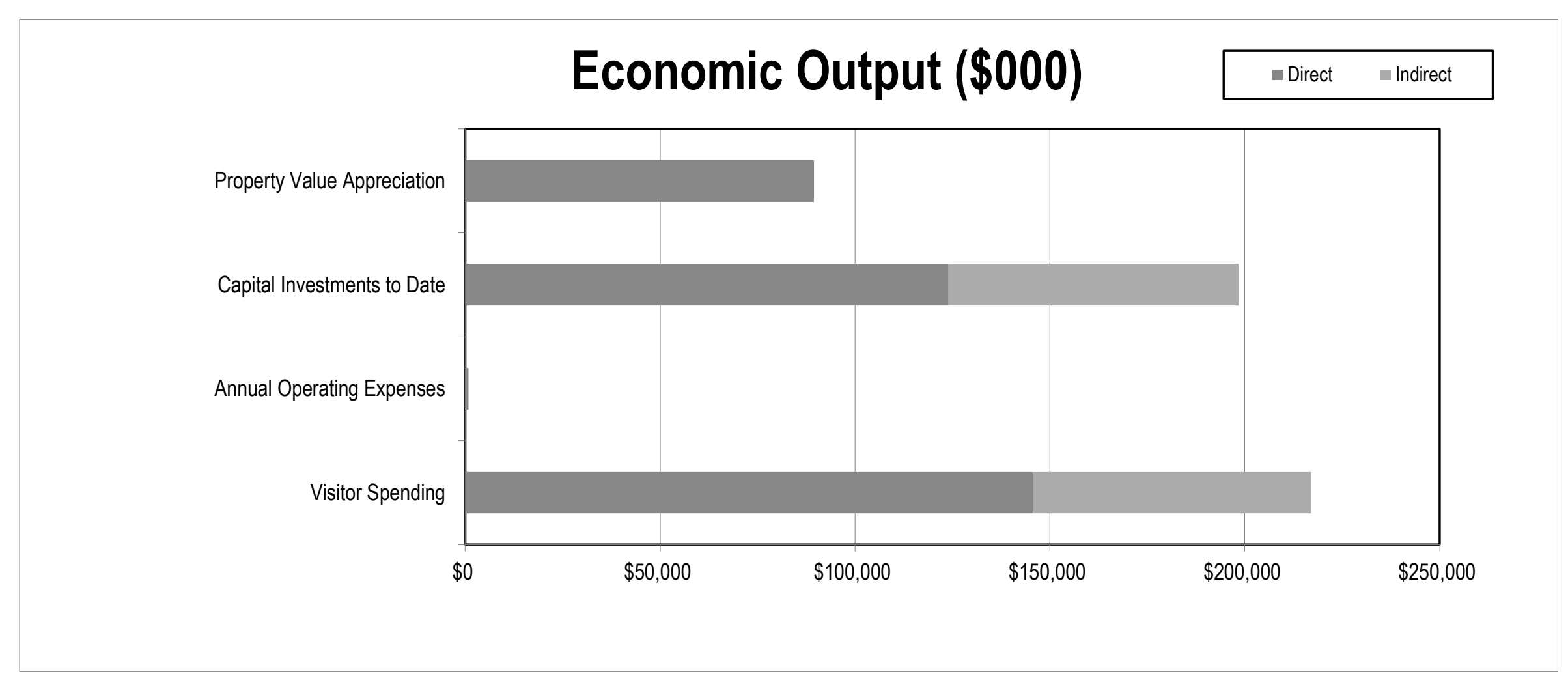

\begin{tabular}{|r}
\hline Total Output \\
Property Value \\
Appreciation \\
Capital \\
Investments \\
Operating \\
Expenses \\
Visitor \\
Spending \\
\hline
\end{tabular}



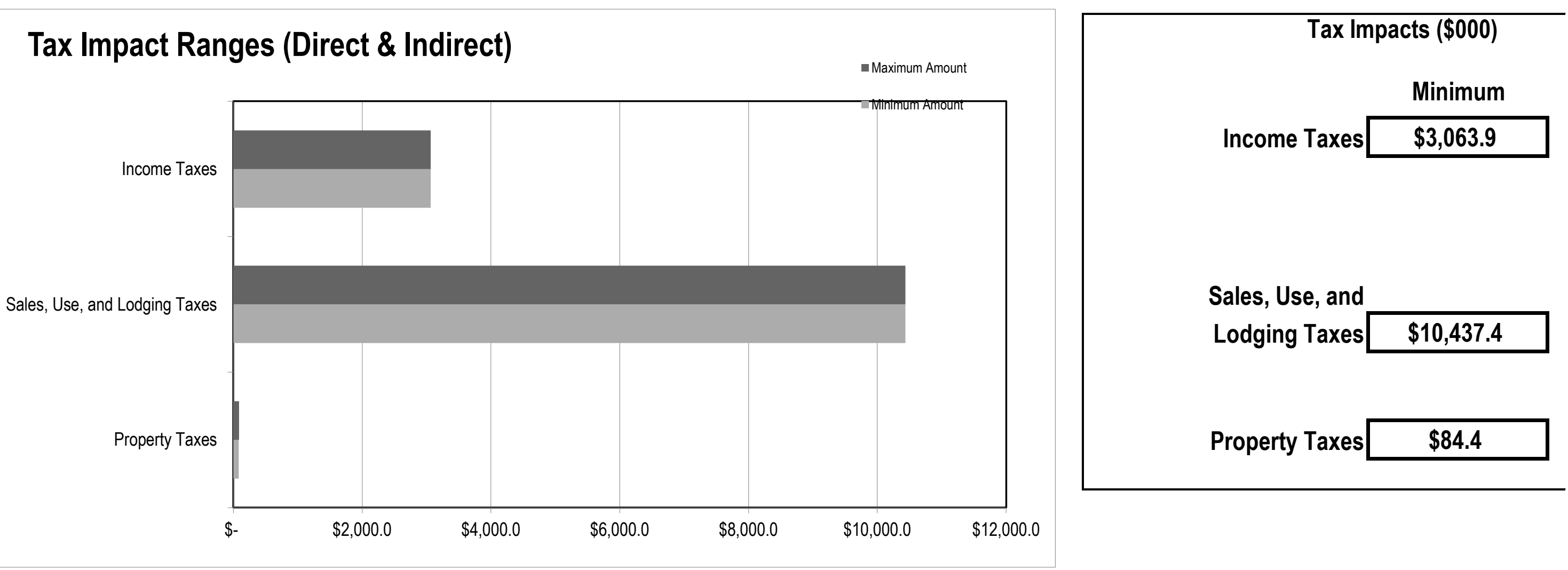

Sales, Use, and

Lodging Taxes \$10,437.4

Property Taxes $\$ 84.4$ 


\section{Visitor Spending Summary}

Name of Analysis

Geographic Area of Analysis

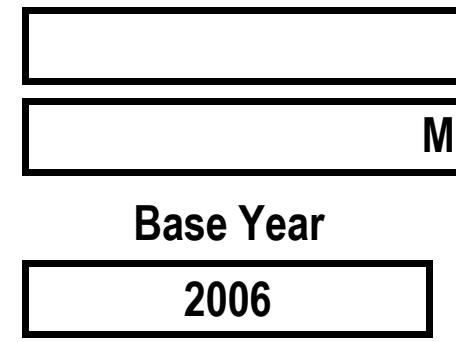

BCP: Update

ulti-County Region in:

Analysis Period

Visitation Summary

Total Visitation

Total Travel Parties

Total Overnight Visitors

Total Daytrippers

Visitor Spending (\$000)

\begin{tabular}{|l}
\hline Total Spending \\
\hline
\end{tabular}

Entertainment \& Recreation

Restaurant Food/Drink

Groceries

Gas Stations

Private Hotels/Campgrounds

Public Campgrounds/Lodges

Rental Homes/Cottages

Transportation

Retail Purchases

Services Purchases
Base Year

$5,399,000$

$1,542,571$

$4,319,200$

$1,889,650$

Direct Impacts

Indirect Impacts

$71,304.5$

Total Impacts

$10,886.6$

$4,832.7$

$10,107.9$

\begin{tabular}{|c|r|}
\hline $22,411.5$ & $51,684.7$ \\
\hline- & - \\
\hline $1,686.5$ & $4,077.1$ \\
\hline $1,126.3$ & $2,367.3$ \\
\hline $17,837.6$ & $37,547.6$ \\
\hline$(6,825.9)$ & - \\
\hline
\end{tabular}

$22,411.5$

\begin{tabular}{|c|r|}
\hline $2,411.5$ & $51,684.7$ \\
\hline $1,686.5$ & - \\
\hline $1,126.3$ & $4,077.1$ \\
\hline $17,837.6$ & $2,367.3$ \\
\hline$(6,825.9)$ & $37,547.6$ \\
\hline
\end{tabular}

View All

View Summary 


\section{Change in Visitation, Base Year to Current Year}

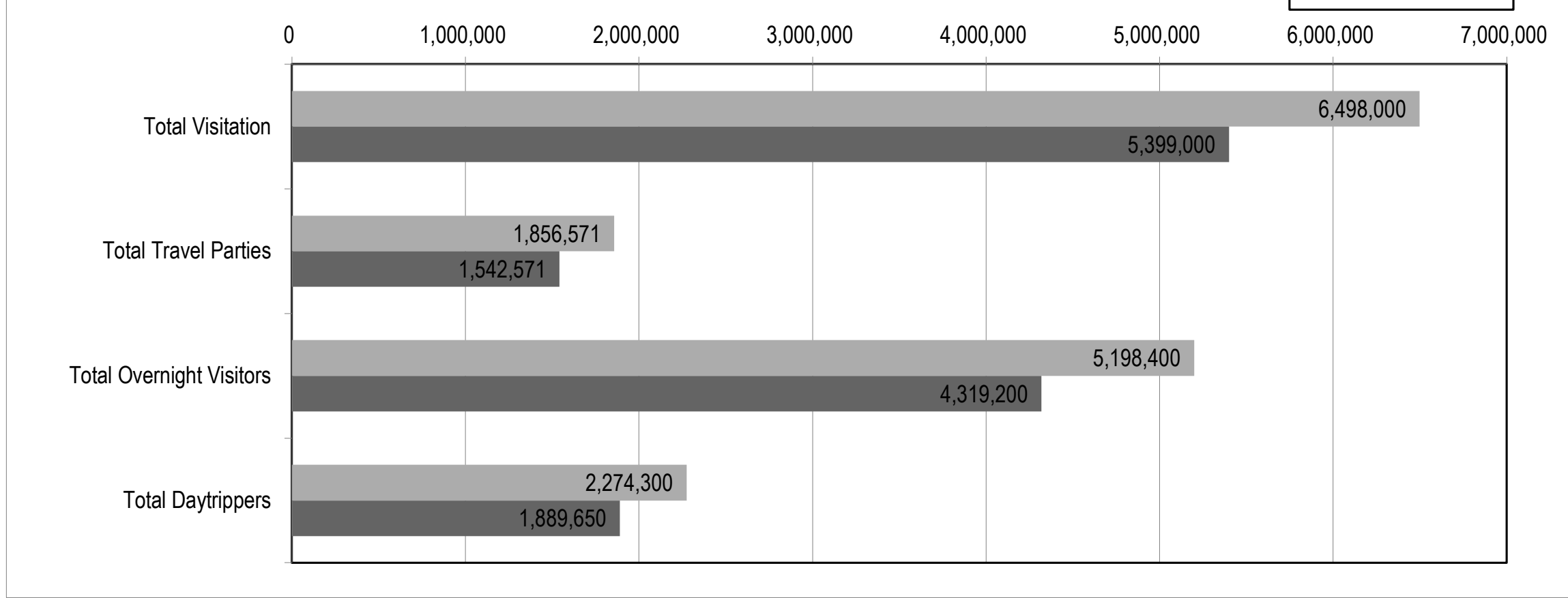




\section{New Visitor Spending by Sector $(\$ 000)$}

\begin{tabular}{|l|}
\hline Direct $\quad$ Indirect \\
\hline
\end{tabular}

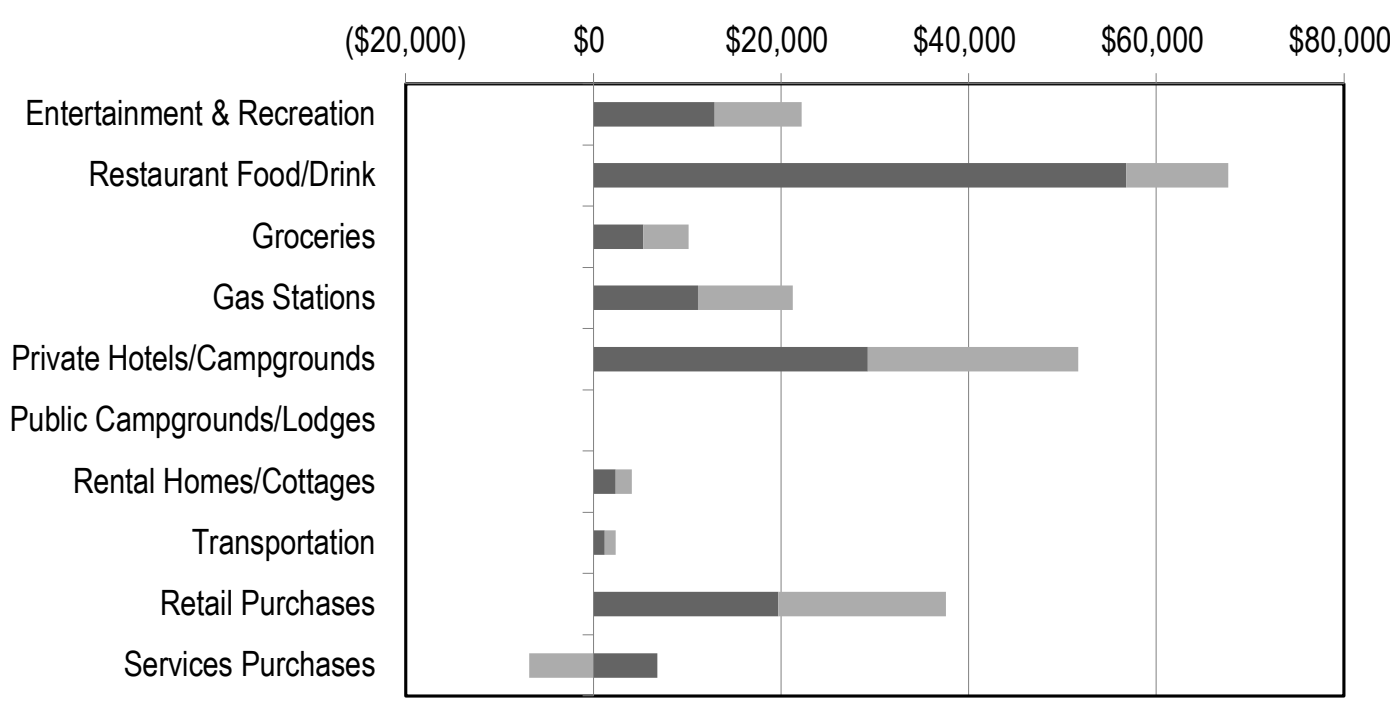

\begin{tabular}{|r|}
\hline$\$ 216,951.6$ \\
\hline$\$ 22,178.8$ \\
\hline $67,646.6$ \\
\hline $10,172.7$ \\
\hline $21,276.9$ \\
\hline $51,684.7$ \\
\hline- \\
\hline $4,077.1$ \\
\hline $2,367.3$ \\
\hline $37,547.6$ \\
\hline- \\
\hline
\end{tabular}




\section{Other Economic Output Results}

(Non-Visitor Spending Only)

Name of Analysis

Geographic Area of Analysis

\begin{tabular}{|c|c|}
\hline \multicolumn{2}{|c|}{ BCP: Update } \\
\hline \multicolumn{2}{|c|}{ Multi-County Region in: } \\
\hline Base Year & Current Year \\
\hline 2006 & 2012 \\
\hline
\end{tabular}

Analysis Period

\begin{tabular}{|c|c|c|}
\hline Direct Impacts & Indirect Impacts & Total Impacts \\
\hline
\end{tabular}

\begin{tabular}{|c|c|c|c|c|c|c|}
\hline & & Direct Impacts & & npacts & & Impacts \\
\hline \multicolumn{7}{|c|}{ Annual Operating Expenses $(\$ 000)$} \\
\hline Total Operating Expenses & $\$$ & 544.0 & $\$$ & 326.2 & $\$$ & 870.2 \\
\hline \multicolumn{7}{|c|}{ Capital Investments to Date $(\$ 000)$} \\
\hline Public/Nonprofit Investments & $\$$ & $124,534.2$ & $\$$ & $57,847.2$ & $\$$ & $182,381.4$ \\
\hline Private Investments & & - & & - & & - \\
\hline Total Capital Investments & & $124,534.2$ & & $57,847.2$ & & $182,381.4$ \\
\hline \multicolumn{7}{|c|}{ Property Value Appreciation (\$000) } \\
\hline Total Appreciation & $\$$ & $89,463.7$ & & NA & & NA \\
\hline
\end{tabular}




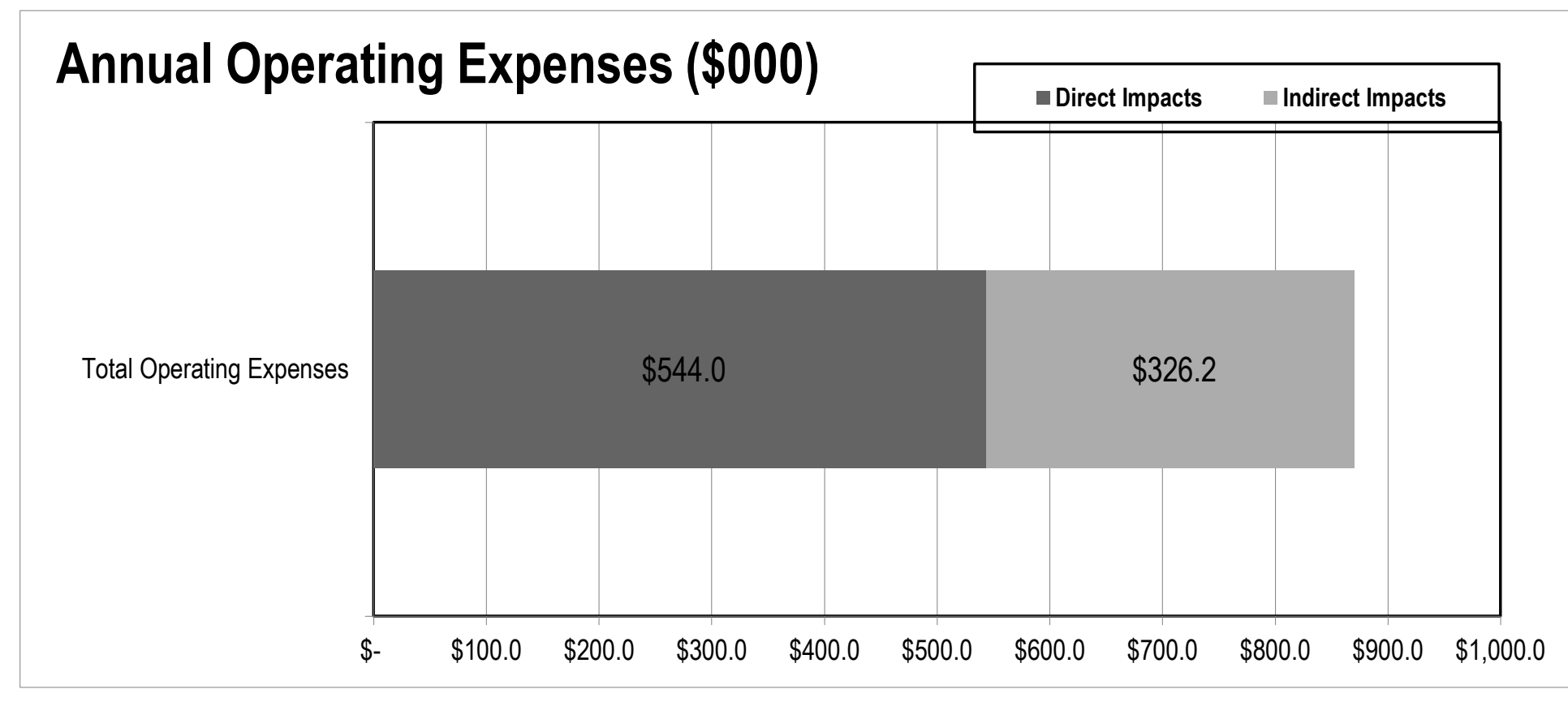

Conital Inunetmante tn Rata I ConnI 


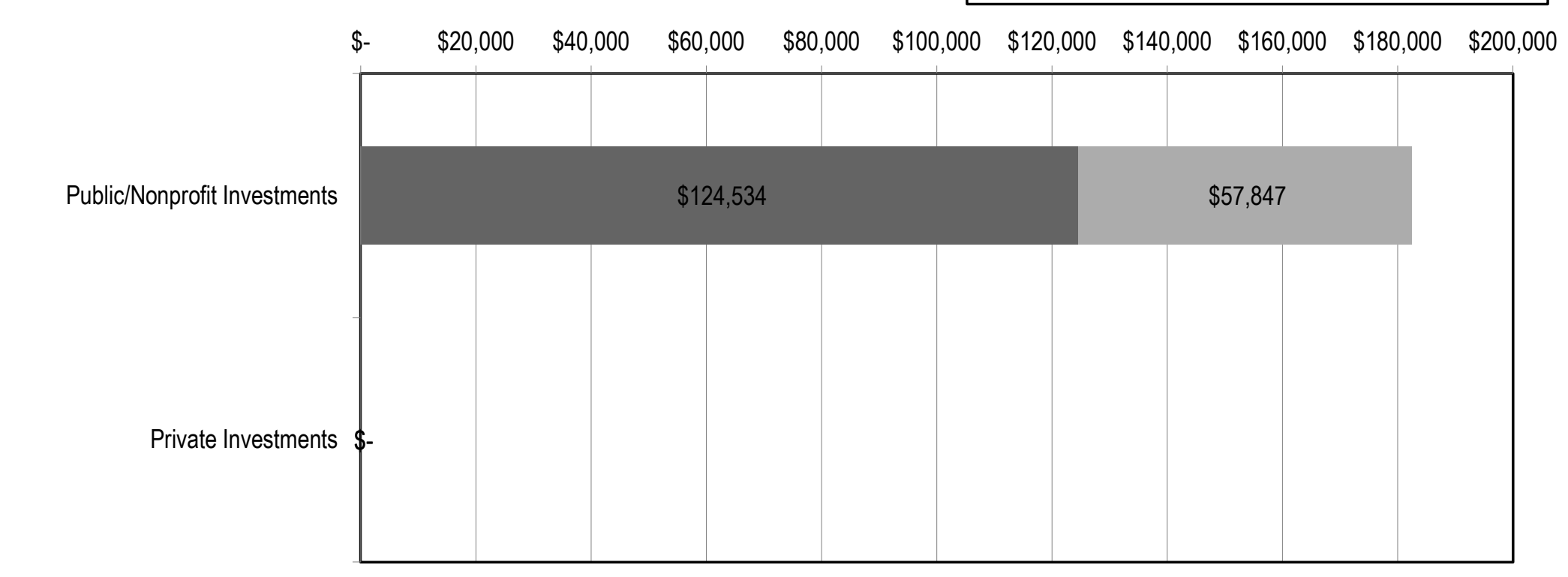

\begin{tabular}{|c|c|c|}
\hline \multicolumn{3}{|c|}{ Total Direct \& Indirect Investments (\$000) } \\
\hline Total Investments & & $182,381.4$ \\
\hline Public/Nonprofit & $\$$ & $182,381.4$ \\
\hline Private & $\$$ & - \\
\hline
\end{tabular}




\section{Property Value}

Appreciation (\$000)

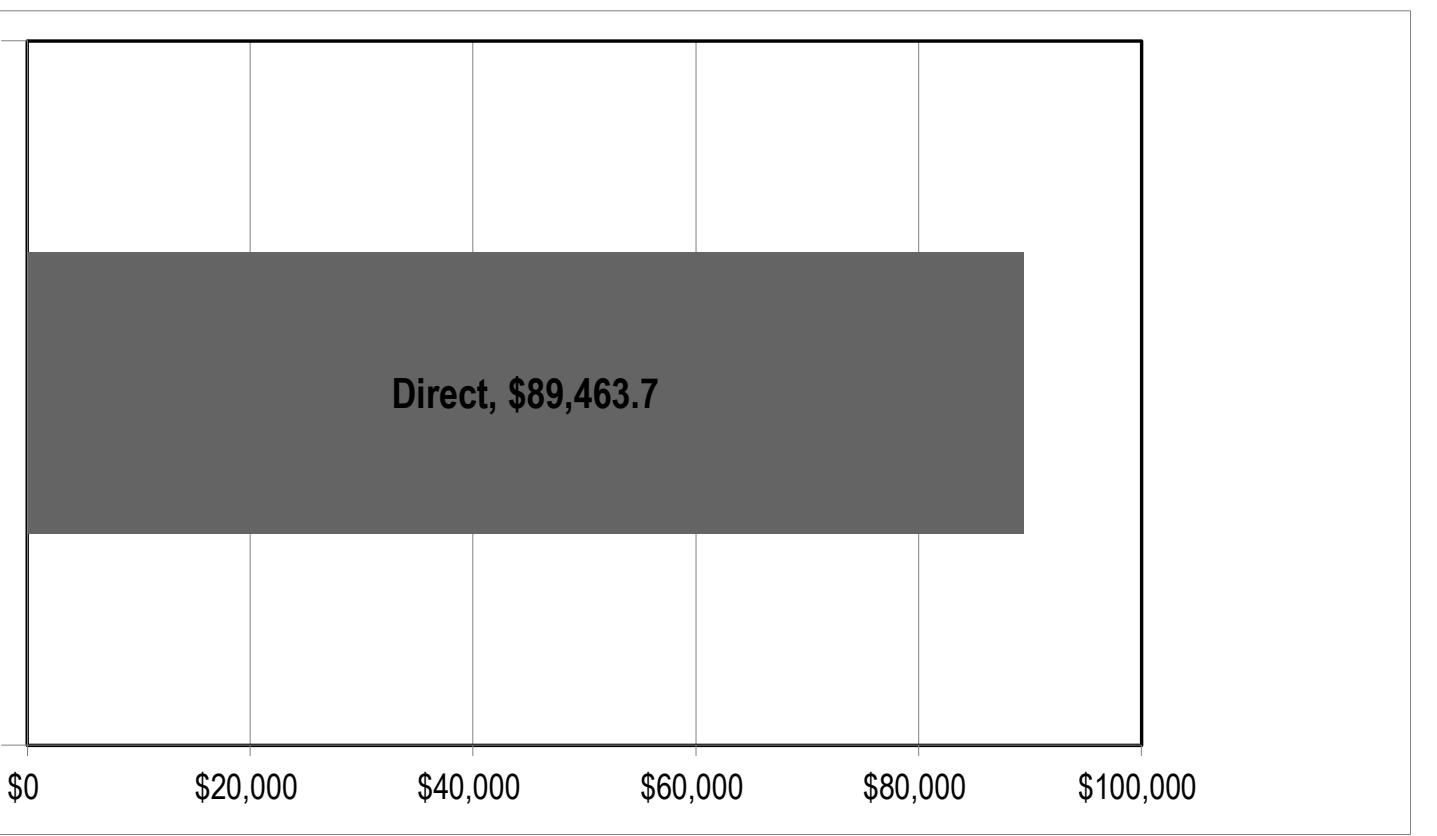




\section{Employment Impact Summary}

Name of Analysis

Geographic Area of Analysis

Analysis Period

\begin{tabular}{|c|c|}
\hline \multicolumn{2}{|c|}{ BCP: Update } \\
\hline \multicolumn{2}{|c|}{ Multi-County Region in: } \\
\hline Base Year & Current Year \\
\hline 2006 & 2012 \\
\hline
\end{tabular}

\section{Direct Impacts}

Indirect Impacts

Total Impacts

Employment Change from Capital (One-Time) Investments

Public Investments

Private Investments

Total from Capital Investments

\begin{tabular}{|r|r|r|}
\hline 737.5 & 533.8 & $1,271.2$ \\
\hline \#DIV/0! & \#DIV/0! & - \\
\hline \#DIV/0! & \#DIV/0! & $\mathbf{1 , 2 7 1 . 2}$ \\
\hline
\end{tabular}

Employment Change from Operating (Ongoing) Investments

Operating Expenses

Visitor Spending

Total from Operating Investments

3.2

Total Byway Related Employment Change

\begin{tabular}{r|r}
3.2 \\
$1,213.2$
\end{tabular}

$1,213.2$

\begin{tabular}{|r|r|}
\hline 2.9 & 6.1 \\
\hline$(175.0)$ & $1,038.2$ \\
\hline$(172.1)$ & $1,044.3$ \\
\hline
\end{tabular}

ADIVI0!
(172.1)

$1,044.3$

Total Employment Change in Byway Region From 2006 to 2012

\#DIV/0!

$2,315.6$

Byway Related Change as \% of Total Regional Change

\#DIV/0!

52,043




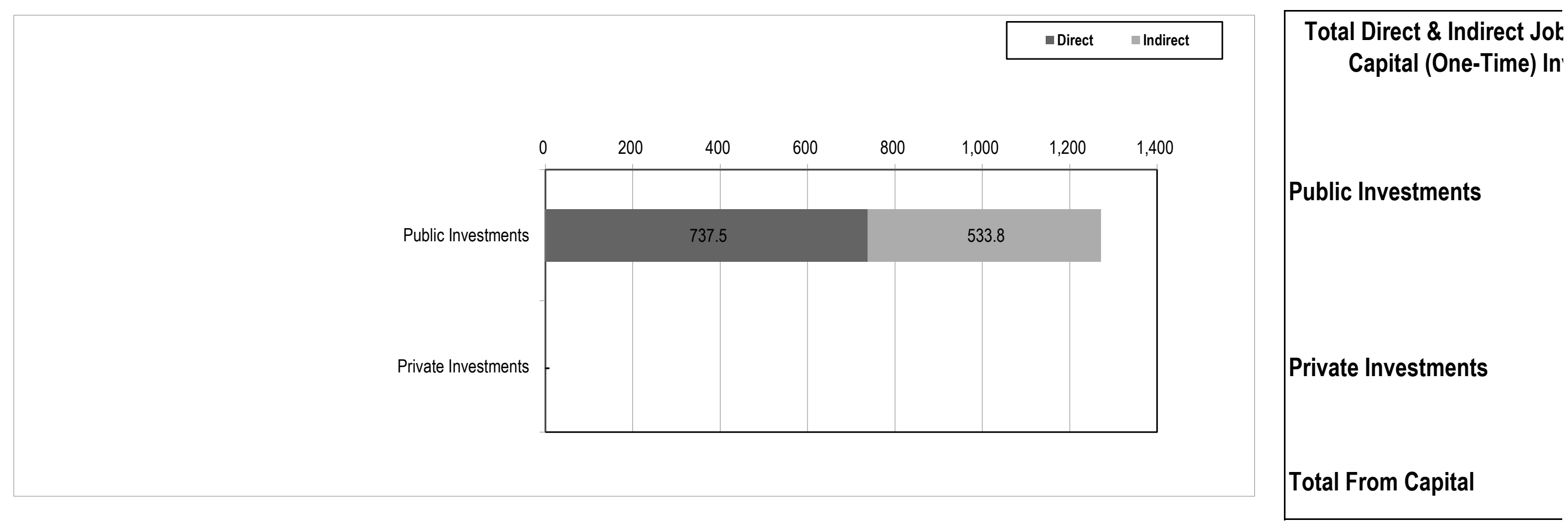




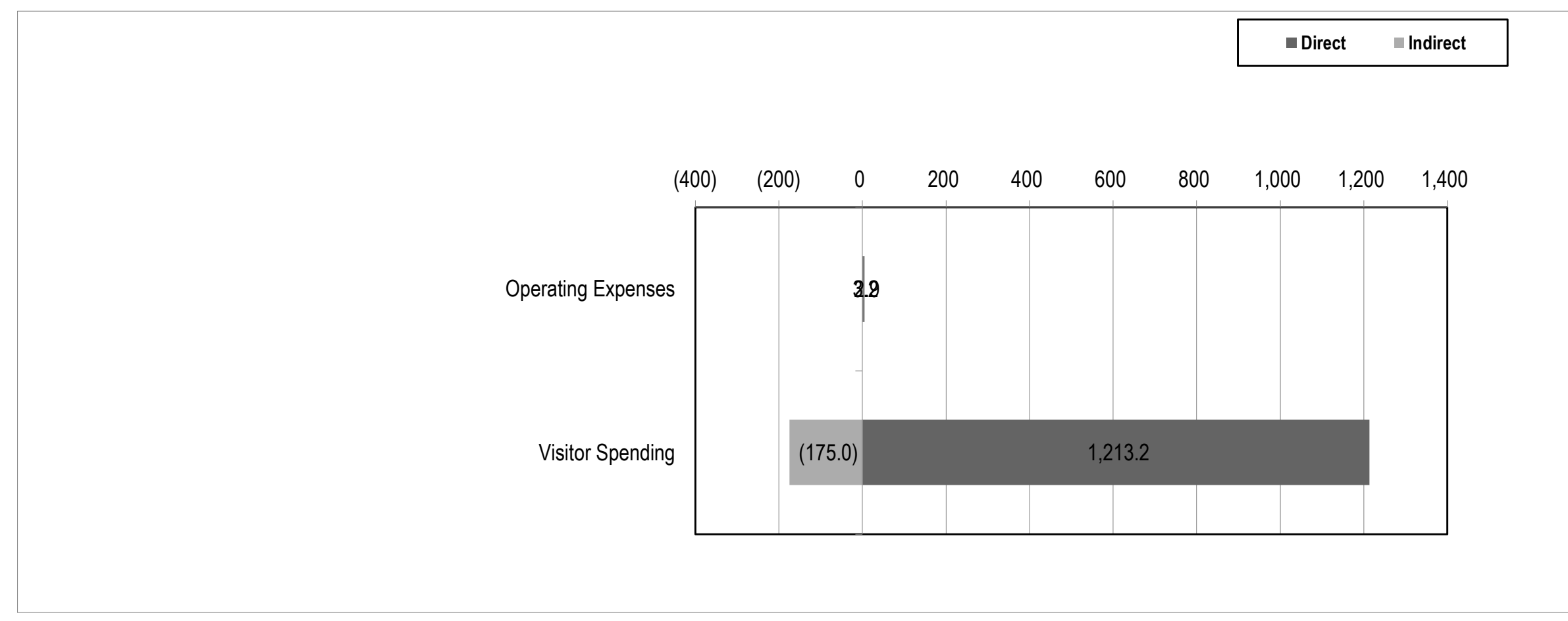
Total Direct \& Indirect Jok
Operating (Ongoing) II

Operating Expenses

Visitor Spending

Total from Operating 


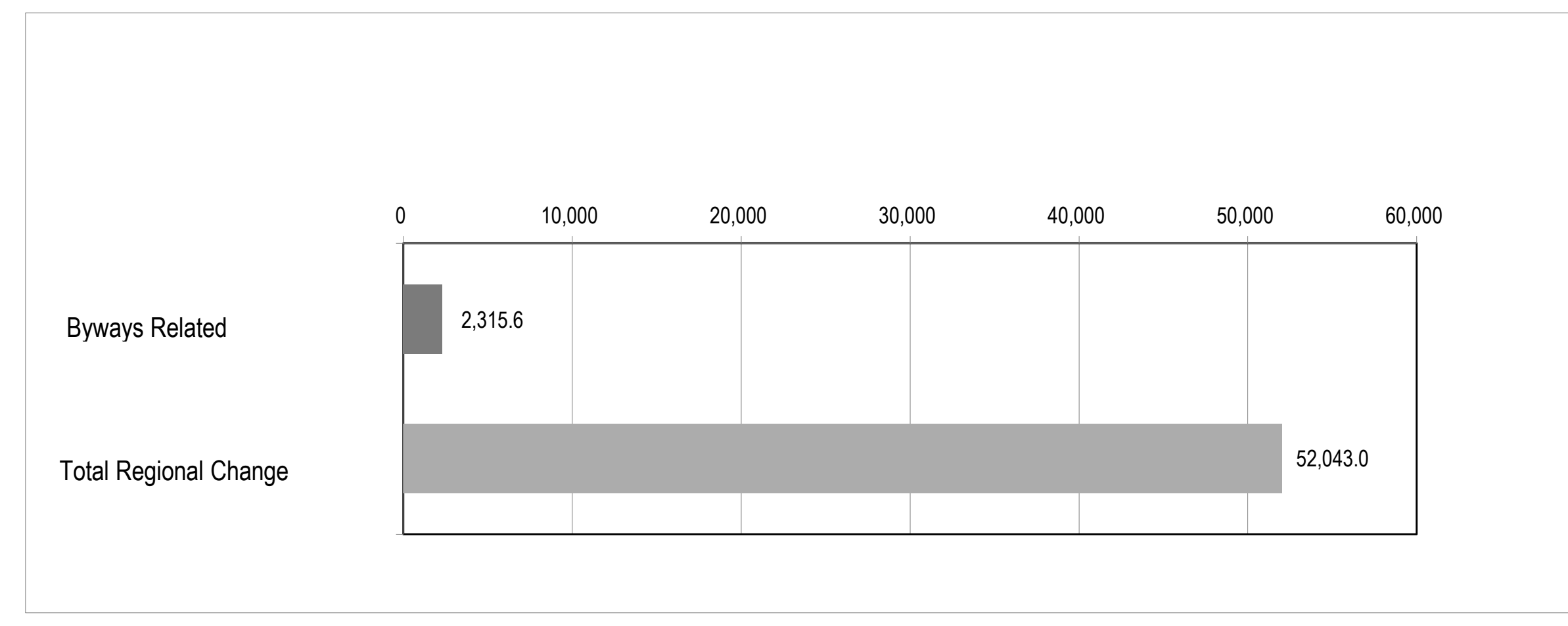

Total Byway-Related Empl as Share of Regional Empl

Byway-Related

Employment Change

Total Regional

Employment Change

Byway Change as \%

of Region Change 


\section{Earnings Impact Summary}

Name of Analysis

Geographic Area of Analysis

Analysis Period

\begin{tabular}{|c|}
\hline \multicolumn{2}{|c|}{ BCP: Update } \\
\hline \multicolumn{2}{|c|}{ Multi-County Region in: } \\
\hline Base Year \\
\hline 2006 \\
\end{tabular}

Direct Impacts

Indirect Impacts

Total Impacts

Earnings Change from Capital (One-Time) Investments, $\$ 000$

Public Investments

Private Investments

Total from Capital Investments

$11,943.9 \times$

\#DIV/O!

\#DIV/0!

$15,540.0$ \$

\#DIV/0!

Earnings Change from Operating (Ongoing) Investments, $\$ 000$

\begin{tabular}{|r|r|rr|rr|}
\hline (Ongoing) Investments, $\$ 000$ \\
& $\$ 148.0$ & $\$$ & 89.6 & $\$$ & 237.7 \\
\hline & 23.461 .5 & & $(118.6)$ & & 23.342 .9 \\
\hline
\end{tabular}

\begin{tabular}{l|l}
\hline Visitor Spending & 23,4615
\end{tabular}

Total from Operating Investments

$23,609.5$ \$

\begin{tabular}{l|ll}
$(29.0)$ & $\$$ & $23,580.6$ \\
\hline
\end{tabular}

Total Byway Related Earnings Change

\#DIV/0!

\#DIV/0! $\$ \quad 51,064.4$

Total Earnings Change in Byway Region From 2006 to 2012, \$000 $\$ 22,427,730.0$
Resource 


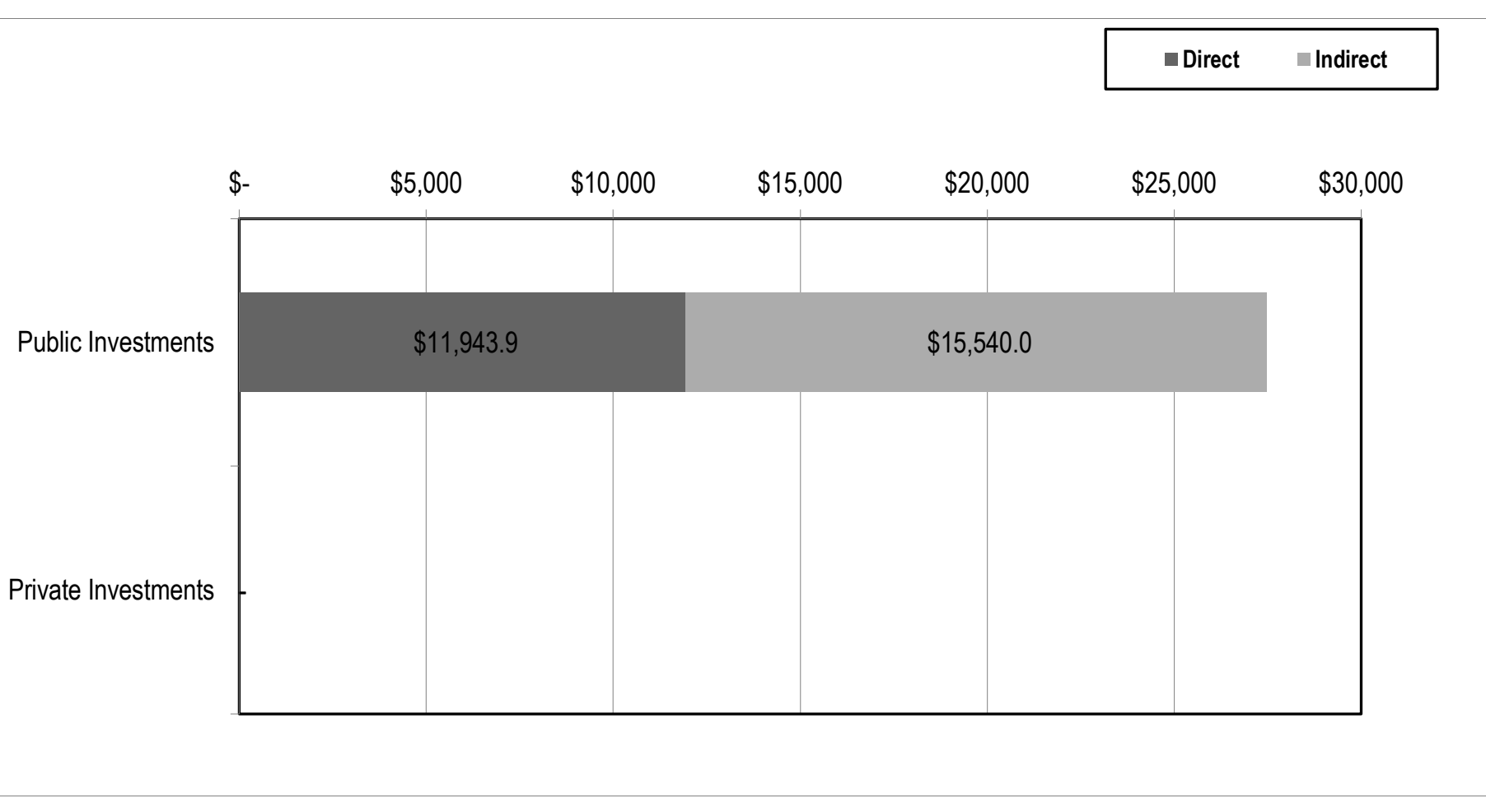

\begin{tabular}{|l|}
\hline $\begin{array}{l}\text { Total Direct \& Indirect Earnings Change From Capital } \\
\text { (One-Time) Investments, } \$ 000\end{array}$ \\
Public Investments \\
Private Investments \\
Total From Capital \\
\hline
\end{tabular}




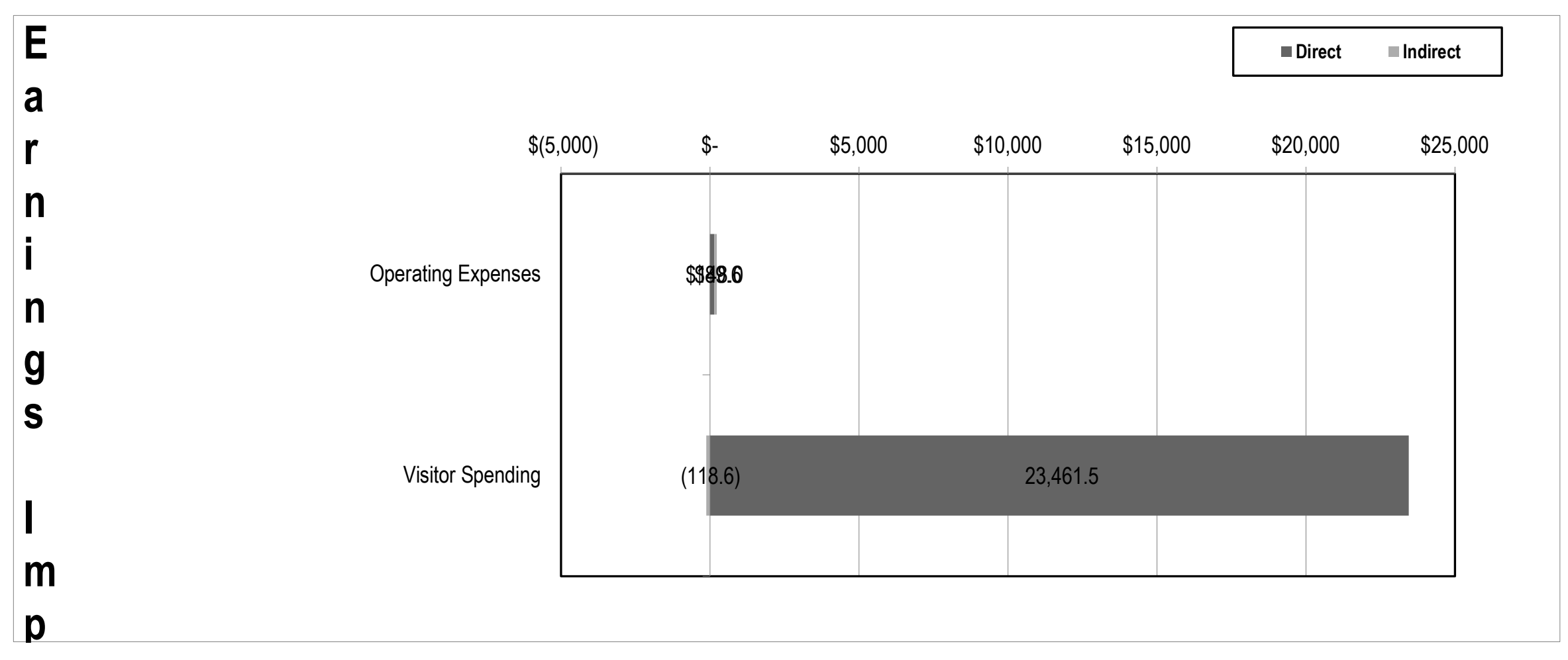

\begin{tabular}{|c|c|c|}
\hline \multicolumn{3}{|c|}{$\begin{array}{l}\text { Total Direct \& Indirect Earnings Change From } \\
\text { Operating (Ongoing) Investments, } \$ 000\end{array}$} \\
\hline Operating Expenses & $\$$ & 237.7 \\
\hline Visitor Spending & $\$$ & $23,342.9$ \\
\hline Total from Operating & $\$$ & $23,580.6$ \\
\hline
\end{tabular}




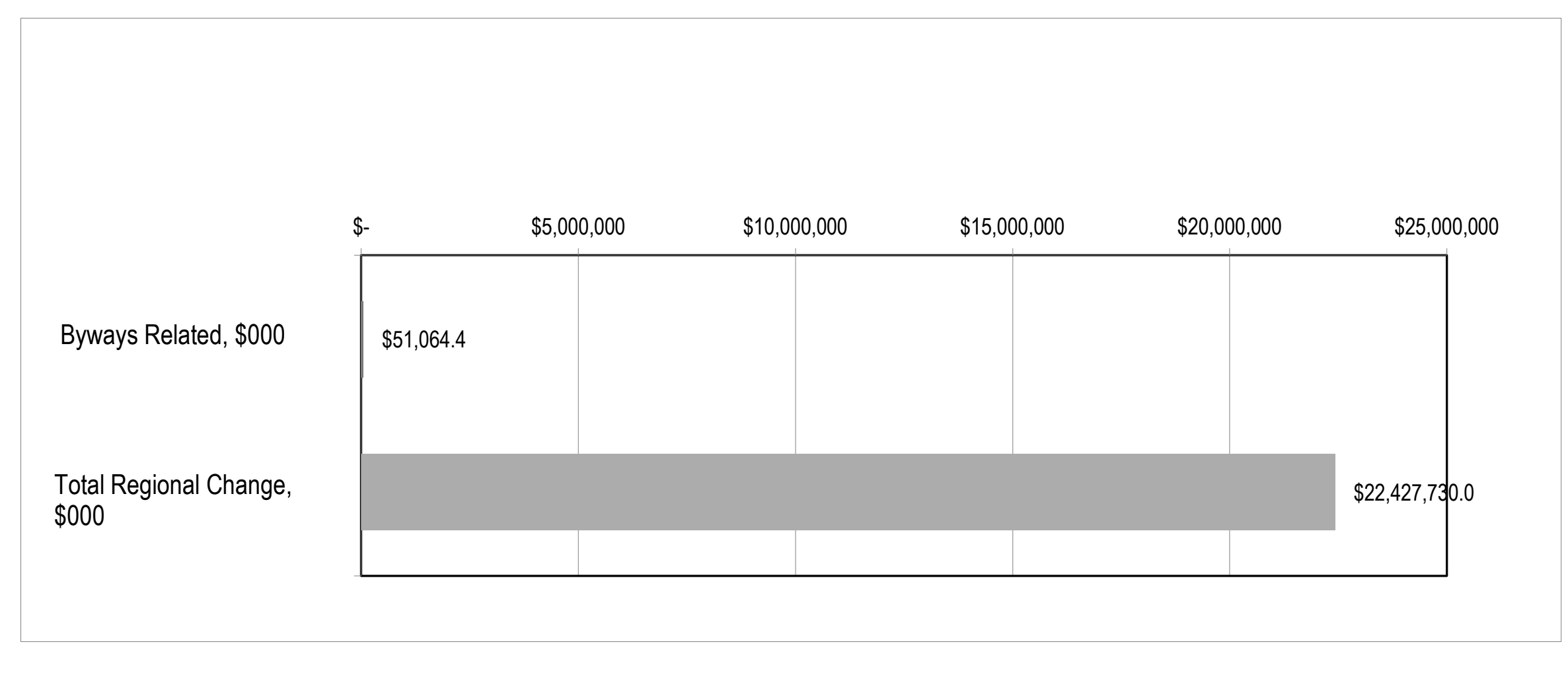

Total Byway-Related Employment Change as Share of Regional Employment Change

\section{Byway-Related}

Earnings Change, $\$ 000$

$\$ \quad 51,064.4$

Total Regional

Earnings Change, $\$ 000$

$\$ 22,427,730.0$

Byway Change as \%

of Region Change

$0.23 \%$ 


\section{Tax Impact Summary}

Includes all Direct \& Indirect Impacts

Name of Analysis

Geographic Area of Analysis

\begin{tabular}{|cc|}
\hline \multicolumn{2}{|c|}{ BCP: Update } \\
\hline \multicolumn{3}{|c|}{ Multi-County Region in: } \\
\hline Base Year & Current Year \\
\hline 2006 & 2012 \\
\hline
\end{tabular}

Analysis Period

2006

\begin{tabular}{|c|c|c|c|c|c|c|}
\hline \multirow{2}{*}{$\begin{array}{l}\text { All Values in } \$ 000 \\
\text { Value/Sales/Earnings Increase }\end{array}$} & \multicolumn{2}{|c|}{ Property Taxes } & \multicolumn{2}{|c|}{ Sales/Use/Lodging Taxes } & \multicolumn{2}{|c|}{ Income Taxes } \\
\hline & $\$$ & $89,463.7$ & $\$$ & $143,256.5$ & $\$$ & $51,064.4$ \\
\hline \multicolumn{7}{|l|}{ Minimum Tax Amount } \\
\hline Jurisdiction & & San Luis Obipo & & SLO County & & California \\
\hline Primary Tax Rate & & $\$ 0.94376$ per $\$ 1,000$ & & $8.0 \%$ & & $6.0 \%$ \\
\hline Tax Revenue & $\$$ & 84.4 & $\$$ & $10,437.4$ & $\$$ & $3,063.9$ \\
\hline \multicolumn{7}{|l|}{ Maximum Tax Amount } \\
\hline Jurisdiction & & Cayucos & & SLO County & & California \\
\hline Primary Tax Rate & & $\$ 0.991653$ per $\$ 1,000$ & & $8.0 \%$ & & $6.0 \%$ \\
\hline Tax Revenue & $\$$ & 88.7 & $\$$ & $10,437.4$ & $\$$ & $3,063.9$ \\
\hline
\end{tabular}

Note: Sales/Use/Lodging tax rates vary for different types of purchases. This table only displays General Sales \& Use Tax rates. 
Tax Impact Ranges (\$000) Includes Direct \& Indirect Impacts

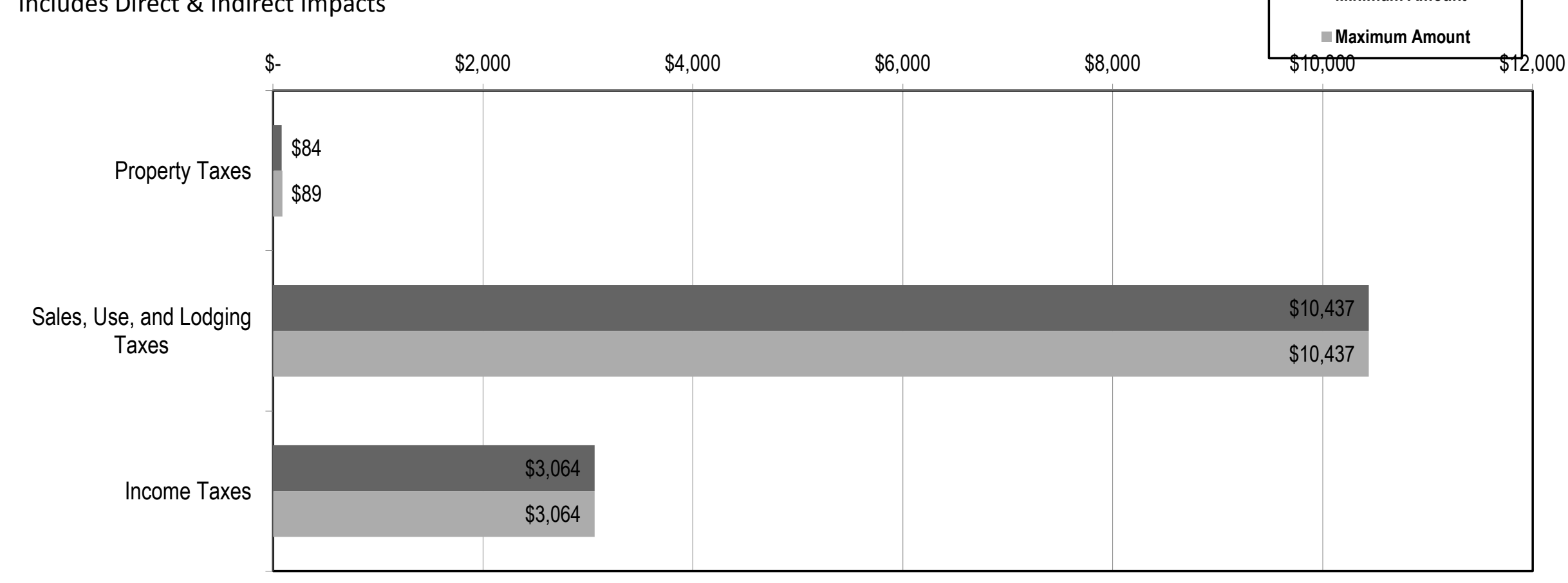




\section{Investment Impacts by Intrinsic Quality}

Includes Direct \& Indirect Impacts from Capital and Operating Investments

Name of Analysis

BCP: Update

Geographic Area of Analysis

\begin{tabular}{|c|}
\hline \multicolumn{2}{|c|}{ BCP: Update } \\
\hline \multicolumn{2}{|c|}{ Multi-County Region in: } \\
\hline Base Year \\
\hline 2006 \\
\\
\hline
\end{tabular}

View Summary Charts:

Analysis Period

Intrinsic Qualities

\begin{tabular}{|c|c|c|c|c|c|c|}
\hline & \multicolumn{6}{|c|}{ Intrinsic Qualities } \\
\hline Investment Source & Archaeological & Cultural & Historic & Natural & Recreational & Scenic \\
\hline \multicolumn{7}{|l|}{ Economic Output (\$000) } \\
\hline Public & $\$ 0.0$ & $\$ 0.0$ & $\$ 0.0$ & $\$ 0.0$ & $\$ 0.0$ & $\$ 0.0$ \\
\hline Private & $\$ 0.0$ & $\$ 0.0$ & $\$ 0.0$ & $\$ 0.0$ & $\$ 0.0$ & $\$ 0.0$ \\
\hline Total & $\$ 0.0$ & $\$ 0.0$ & $\$ 0.0$ & $\$ 0.0$ & $\$ 0.0$ & $\$ 0.0$ \\
\hline \multicolumn{7}{|l|}{ Earnings (\$000) } \\
\hline Public & $\$ 0.0$ & $\$ 0.0$ & $\$ 0.0$ & $\$ 0.0$ & $\$ 0.0$ & $\$ 0.0$ \\
\hline Private & $\$ 0.0$ & $\$ 0.0$ & $\$ 0.0$ & $\$ 0.0$ & $\$ 0.0$ & $\$ 0.0$ \\
\hline Total & $\$ 0.0$ & $\$ 0.0$ & $\$ 0.0$ & $\$ 0.0$ & $\$ 0.0$ & $\$ 0.0$ \\
\hline \multicolumn{7}{|l|}{ Employment (Jobs) } \\
\hline Public & 0.0 & 0.0 & 0.0 & 0.0 & 0.0 & 0.0 \\
\hline Private & 0.0 & 0.0 & 0.0 & 0.0 & 0.0 & 0.0 \\
\hline Total & 0.0 & 0.0 & 0.0 & 0.0 & 0.0 & 0.0 \\
\hline
\end{tabular}




\section{Total}

Economic Output (\$000)

Includes all Direct \& Indirect Impacts

Except for Property

Value Appreciation.

Capital and Operating

Investments are

Aggregated.

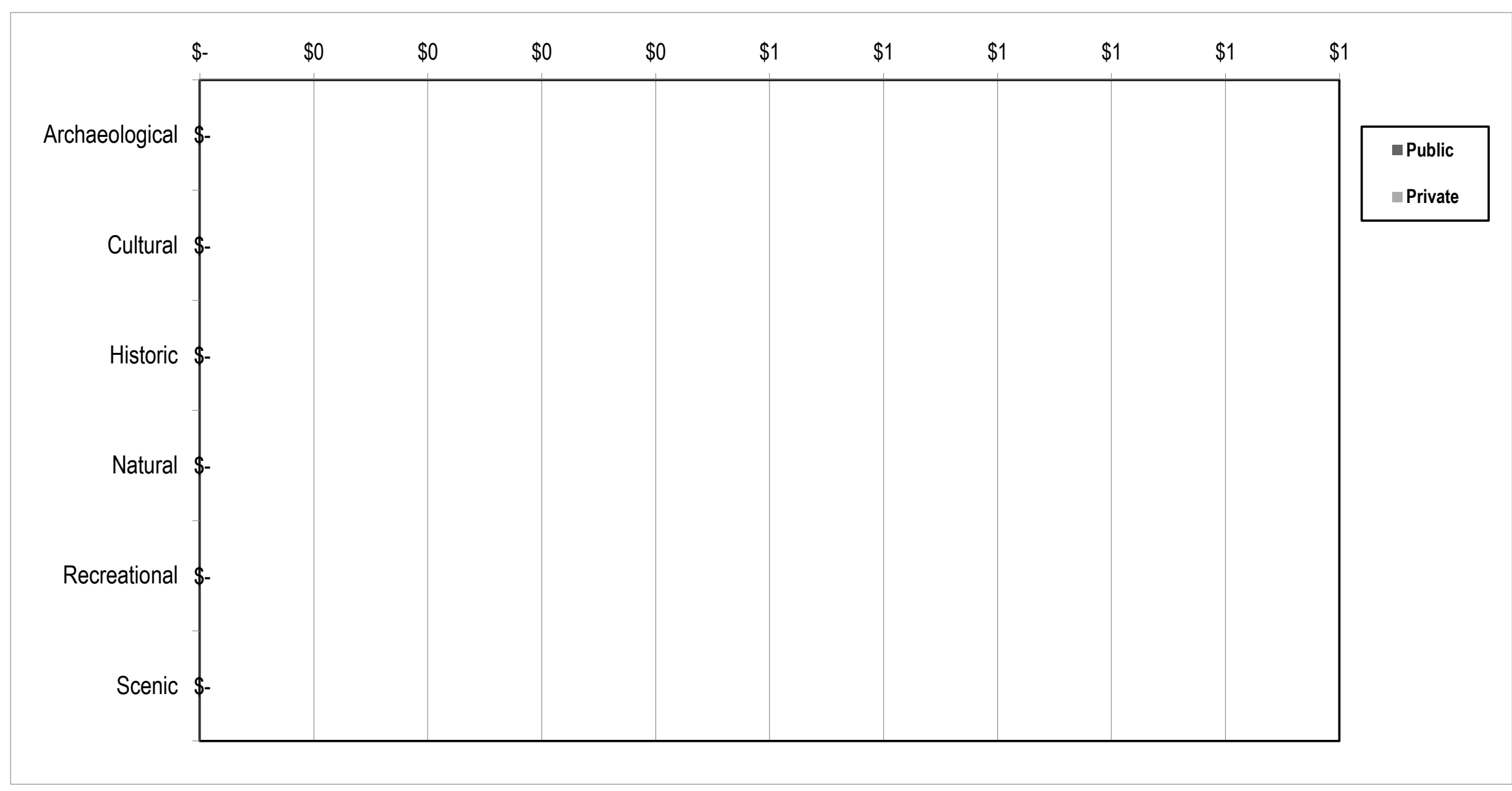




\section{Total}

Earnings

$(\$ 000)$

Includes all Direct \& Indirect Impacts Except for Property Value Appreciation. Capital and Operating Investments are Aggregated.

$\exists \cdots$


Total

Employment

Includes all Direct \& Indirect Impacts

Except for Property

Value Appreciation.

Capital and Operating

Investments are

Aggregated.

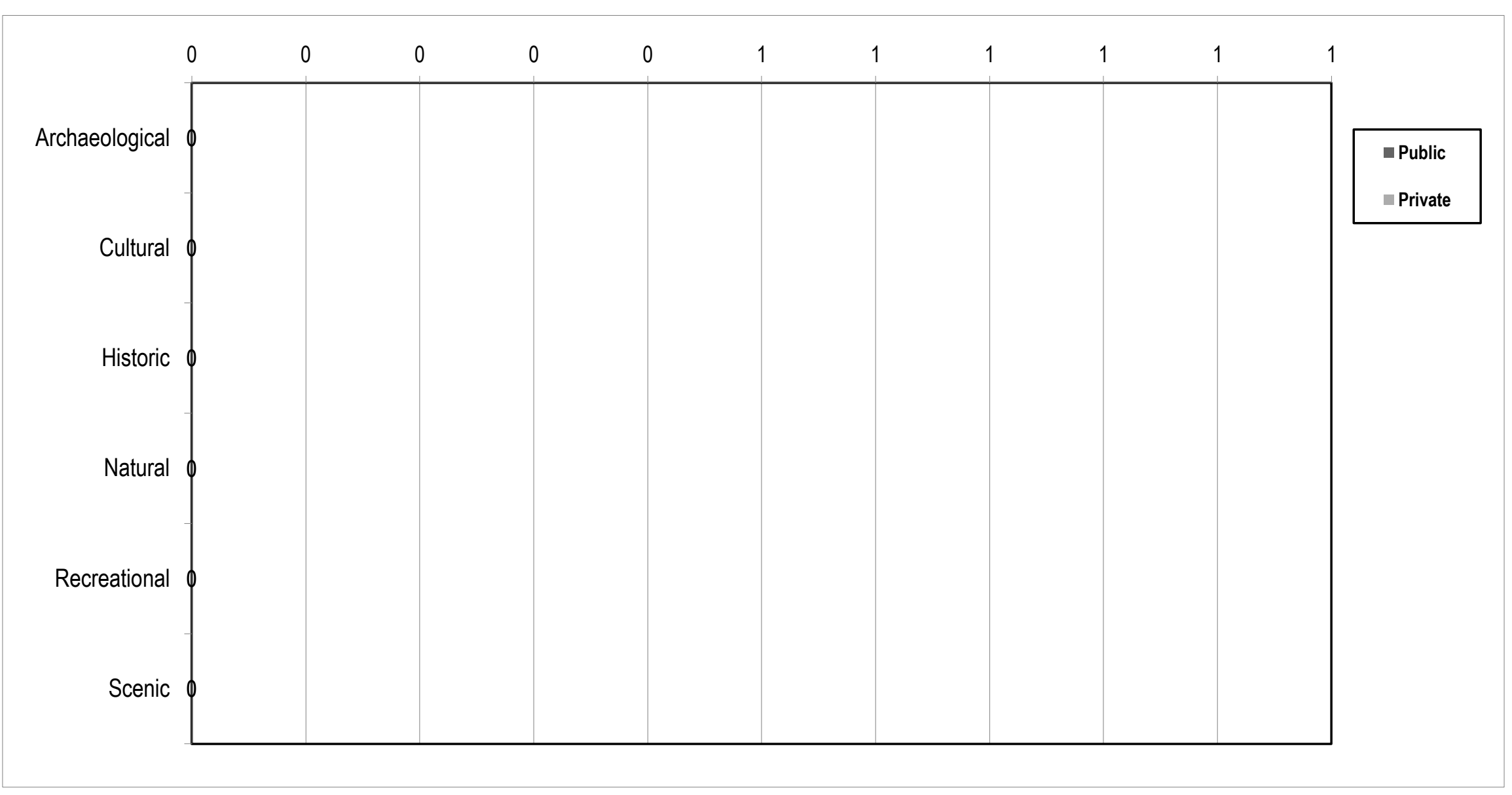


Sales Tax Rates/What do Rates Apply to?

Source: Federation of Tax Administrators, 2007 Survey

http://www.taxadmin.org/fta/pub/services/services.htm Date of Report: July 1, 2009

Date of Research: July 28,2009

\begin{tabular}{|c|c|c|c|}
\hline \multirow[b]{2}{*}{ State } & \multicolumn{3}{|c|}{ Sales \& Use Tax Rates } \\
\hline & General Sales/Use & Groceries & Prepared Food \\
\hline Alabama & $4.00 \%$ & $4.00 \%$ & $4.00 \%$ \\
\hline Alaska & $0.00 \%$ & $0.00 \%$ & $0.00 \%$ \\
\hline Arizona & $5.60 \%$ & $0.00 \%$ & $5.60 \%$ \\
\hline Arkansas & $6.00 \%$ & $3.00 \%$ & $6.00 \%$ \\
\hline California & $8.25 \%$ & $0.00 \%$ & $8.25 \%$ \\
\hline Colorado & $2.90 \%$ & $0.00 \%$ & $2.90 \%$ \\
\hline Connecticut & $6.00 \%$ & $0.00 \%$ & $6.00 \%$ \\
\hline Delaware & $0.00 \%$ & $0.00 \%$ & $0.00 \%$ \\
\hline District of Columbia & $5.75 \%$ & $0.00 \%$ & $10.00 \%$ \\
\hline Florida & $6.00 \%$ & $0.00 \%$ & $6.00 \%$ \\
\hline Georgia & $4.00 \%$ & $0.00 \%$ & $4.00 \%$ \\
\hline Hawaii & $4.00 \%$ & $4.00 \%$ & $4.00 \%$ \\
\hline Idaho & $6.00 \%$ & $6.00 \%$ & $6.00 \%$ \\
\hline Illinois & $6.25 \%$ & $1.00 \%$ & $6.25 \%$ \\
\hline Indiana & $7.00 \%$ & $0.00 \%$ & $7.00 \%$ \\
\hline lowa & $6.00 \%$ & $0.00 \%$ & $6.00 \%$ \\
\hline Kansas & $5.30 \%$ & $5.30 \%$ & $5.30 \%$ \\
\hline Kentucky & $6.00 \%$ & $0.00 \%$ & $6.00 \%$ \\
\hline Louisiana & $4.00 \%$ & $0.00 \%$ & $4.00 \%$ \\
\hline Maine & $5.00 \%$ & $0.00 \%$ & $7.00 \%$ \\
\hline Maryland & $6.00 \%$ & $0.00 \%$ & $6.00 \%$ \\
\hline Massachusetts & $6.25 \%$ & $0.00 \%$ & $6.25 \%$ \\
\hline \begin{tabular}{|l} 
Michigan \\
\end{tabular} & $6.00 \%$ & $0.00 \%$ & $6.00 \%$ \\
\hline Minnesota & $6.88 \%$ & $0.00 \%$ & $6.88 \%$ \\
\hline Mississippi & $7.00 \%$ & $7.00 \%$ & $9.00 \%$ \\
\hline Missouri & $4.23 \%$ & $1.23 \%$ & $4.23 \%$ \\
\hline Montana & $0.00 \%$ & $0.00 \%$ & $0.00 \%$ \\
\hline Nebraska & $5.50 \%$ & $0.00 \%$ & $5.50 \%$ \\
\hline Nevada & $6.85 \%$ & $0.00 \%$ & $6.85 \%$ \\
\hline New Hampshire & $0.00 \%$ & $0.00 \%$ & $9.00 \%$ \\
\hline New Jersey & $7.00 \%$ & $0.00 \%$ & $7.00 \%$ \\
\hline New Mexico & $5.38 \%$ & $0.00 \%$ & $5.38 \%$ \\
\hline New York & $4.00 \%$ & $0.00 \%$ & $4.00 \%$ \\
\hline North Carolina & $4.50 \%$ & $2.00 \%$ & $7.25 \%$ \\
\hline North Dakota & $5.00 \%$ & $5.00 \%$ & $5.00 \%$ \\
\hline Ohio & $5.50 \%$ & $0.00 \%$ & $5.50 \%$ \\
\hline Oklahoma & $4.50 \%$ & $4.50 \%$ & $4.50 \%$ \\
\hline Oregon & $0.00 \%$ & $0.00 \%$ & $5.00 \%$ \\
\hline \begin{tabular}{|l} 
Pennsylvania \\
\end{tabular} & $6.00 \%$ & $0.00 \%$ & $6.00 \%$ \\
\hline Rhode Island & $7.00 \%$ & $0.00 \%$ & $8.00 \%$ \\
\hline South Carolina & $6.00 \%$ & $0.00 \%$ & $6.00 \%$ \\
\hline South Dakota & $4.00 \%$ & $4.00 \%$ & $4.00 \%$ \\
\hline Tennessee & $7.00 \%$ & $5.50 \%$ & $7.00 \%$ \\
\hline Texas & $6.25 \%$ & $0.00 \%$ & $6.25 \%$ \\
\hline Utah & $4.75 \%$ & $1.75 \%$ & $4.75 \%$ \\
\hline Vermont & $6.00 \%$ & $0.00 \%$ & $10.00 \%$ \\
\hline Virginia & $5.00 \%$ & $2.50 \%$ & $5.00 \%$ \\
\hline Washington & $6.50 \%$ & $0.00 \%$ & $10.00 \%$ \\
\hline West Virginia & $6.00 \%$ & $4.00 \%$ & $6.00 \%$ \\
\hline Wisconsin & $5.00 \%$ & $0.00 \%$ & $5.00 \%$ \\
\hline Wyoming & $4.00 \%$ & $0.00 \%$ & $4.00 \%$ \\
\hline
\end{tabular}

Adjusted Gross Income Data

Source: The Tax Foundation

ata/topic/83.html

Date of Report: August 2008 (2006 Data)
Income Tax Rate Data

Source: The Tax Foundation

Dttp://www.tax foundation.org/taxdata/topic/83.htm Date of Report: July 1, 2009

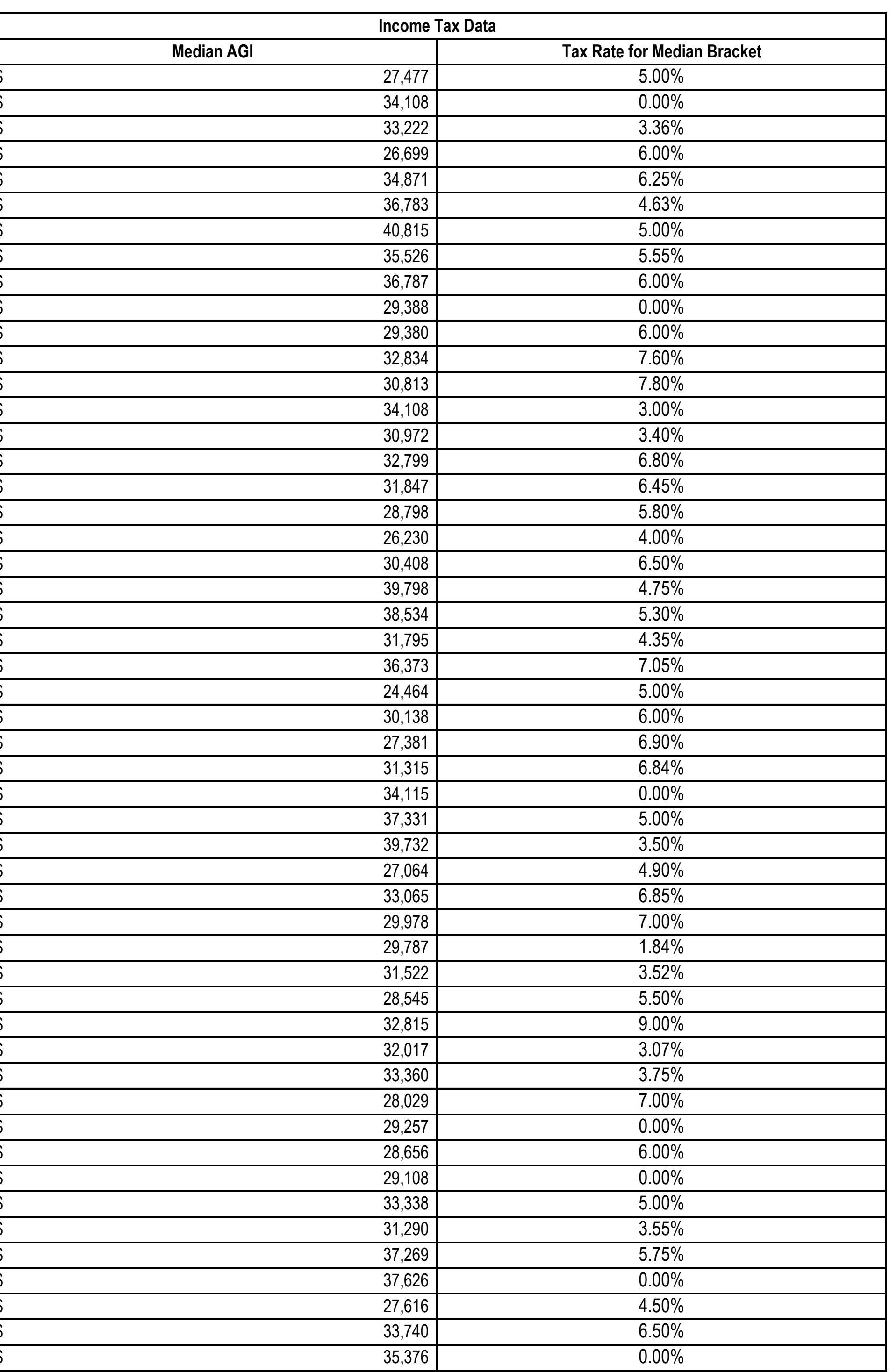




\section{Enter Employment Data}

Source of 2001-2007 Employment Data: U.S. Department of Commerce, Bureau of Economic Analysis, Regional Income Division; projections for 2008 and later completed by Economic Stewardship. Inc. based on these data.

Name of Analysis

Geographic Area of Analysis

\begin{tabular}{|c|c|c|c|c|}
\hline \multirow{2}{*}{$\begin{array}{l}\text { Name of Analysis } \\
\text { Geographic Area of Analysis }\end{array}$} & \multicolumn{2}{|c|}{ BCP: Update } & & \\
\hline & \multicolumn{2}{|c|}{ Multi-County Region in: } & \multicolumn{2}{|c|}{ View All Counties } \\
\hline \multirow{2}{*}{ Employment Sector } & & Base Year & Current Year & Total Change \\
\hline & & 2006 & 2012 & $2006-2012$ \\
\hline Accommodation and food services & $100 \%$ & 434,362 & 450,721 & 16,359 \\
\hline Administrative and waste services & $100 \%$ & 444,421 & 482,543 & 38,122 \\
\hline Arts, entertainment, and recreation & $100 \%$ & 138,675 & 141,720 & 3,045 \\
\hline Construction & $100 \%$ & 382,599 & 394,105 & 11,506 \\
\hline Educational services & $100 \%$ & 145,419 & 153,506 & 8,087 \\
\hline Finance and insurance & $100 \%$ & 442,064 & 439,422 & $(2,642)$ \\
\hline Forestry, fishing, agriculture, and related & $100 \%$ & 15,253 & 13,901 & $(1,352)$ \\
\hline Health care and social assistance & $100 \%$ & 720,375 & 746,486 & 26,111 \\
\hline Information & $100 \%$ & 152,761 & 139,068 & $(13,693)$ \\
\hline Management of companies and enterprises & $100 \%$ & 88,002 & 92,116 & 4,114 \\
\hline Manufacturing & $100 \%$ & 774,415 & 717,260 & $(57,155)$ \\
\hline Mining & $100 \%$ & 17,054 & 16,817 & $(237)$ \\
\hline Other services, except public administration & $100 \%$ & 406,652 & 418,726 & 12,074 \\
\hline Professional and technical services & $100 \%$ & 499,749 & 501,362 & 1,613 \\
\hline Real estate and rental and leasing & $100 \%$ & 228,815 & 255,784 & 26,969 \\
\hline Retail Trade & $100 \%$ & 758,245 & 757,008 & $(1,237)$ \\
\hline Transportation and warehousing & $100 \%$ & 282,346 & 286,619 & 4,273 \\
\hline Utilities & $100 \%$ & 28,733 & 24,640 & $(4,093)$ \\
\hline Wholesale trade & $100 \%$ & 322,011 & 318,077 & $(3,934)$ \\
\hline Government and government enterprises & $100 \%$ & 909,204 & 896,319 & $(12,885)$ \\
\hline Total employment & $100 \%$ & $7,283,845$ & $7,335,888$ & 52,043 \\
\hline
\end{tabular}

BCP: Update 


\section{Visitor Profile Data}

$2 \%$ Daytrippers $\quad 35.00 \%$

$3 \%$ Overnight Visitors $\quad 65.00 \%$

$4 \%$ Living in Primary Impact Area $\quad 20.00 \%$

$5 \%$ Living Outside Primary Impact Area $\quad 80.00 \%$

$6 \%$ Staying in Paid Accommodations $\quad 90.00 \%$

$7 \%$ Staying with Friends/Relatives $\quad 10.00 \%$

8 Average Length of Stay in Region (Days) for All Visitors $\quad 2.00$

9 Average Nights Stayed in Region for Overnight Visitors $\quad 2.00$

10 Average Number of People in Travel Party 3.50

\section{Visitor Spending Data}

Spending Type: otal Annual Spending in Region

\begin{tabular}{|c|c|}
\hline 2 & Entertainment \& Recreation \\
\hline 3 & Restaurant Food/Drink \\
\hline 4 & Groceries \\
\hline 5 & Gas Stations \\
\hline 6 & Private Hotels/Campgrounds \\
\hline 7 & Public Campgrounds/Lodges \\
\hline 8 & Rental Homes/Cottages \\
\hline 9 & Transportation \\
\hline 10 & Retail Purchases \\
\hline 11 & Services Purchases \\
\hline 12 & Total Visitor Spending \\
\hline
\end{tabular}

$\$ 86,250,000.00$

$\$ 189,200,000.00$

$\$ 26,700,000.00$

$\$ 55,845,000.00$

$\$ 97,577,150.00$

$\$ 2,706,300.00$

$\$ 15,937,100.00$

$\$ 6,205,000.00$

$\$ 131,400,000.00$

$\$ 34,129,450.00$

$\$ 645,950,000.00$ 


\section{Visitor Count Data}

Base Year Visitors

Current Year Visitors

\section{INVESTMENT DATA}

\section{Total Investment Value}

Total Investment Value

Total Investments Due to NSB/AAR

$\%$ of Total Due to NSB/AAR

Investments by Source

Federal
State
Local
Tribal Entity
Byway Organization
Other Nonprofit
Private
Total

\section{Investments by Type}

Capital Investment

Operating Expenditure

Investments by Intrinsic Value

\section{TOTAL
Archaelogical \\ TOTAL
Archaelogical}

$5,399,000.00$

$6,498,000.00$

$\$ 124,534,231.00$

$\$ 124,534,231.00$

$100.00 \%$

$\$ 118,723,971.76$
$\$ 3,556,012.44$
$\$ 1,970,746.80$
$\$ 0.00$
$\$ 283,500.00$
$\$ 0.00$
$\$ 0.00$

$\$ 124,534,231.00$

$\$ 123,990,231.00$

$\$ 544,000.00$

Total Amount Spent

$\$ 0.00$

\begin{tabular}{|l|}
\hline S00A00 Other government enterprises \\
\hline S00A00 Other government enterprises \\
\hline S00A00 Other government enterprises \\
\hline S00A00 Other government enterprises \\
\hline 813B00 Civic, social, professional, and similar orga \\
\hline 813B00 Civic, social, professional, and similar orga \\
\hline 61. Other services \\
\hline
\end{tabular}

Multiplier

813B00 Civic, social, professional, and similar orge 813B00 Civic, social, professional, and similar orga

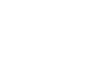




\section{APPENDIX H}

Public Comment 


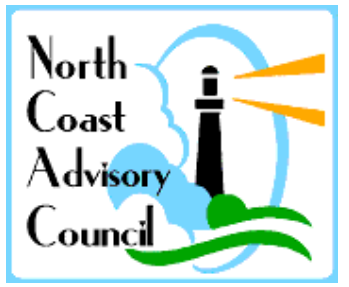

P.O. Box 533

Cambria, CA 93428

(805) 927-4402

May 22, 2014

San Luis Obispo North Coast Scenic Byway Corridor Plan 2014

Draft Scenic Byway Corridor Plan comments and suggested changes

agreed upon by the North Coast Advisory Council (NCAC) of Cambria \&

San Simeon at the May 21, 2014 general meeting:

General Commentary on document content:

- Chapter 2. Byway Vision and Improvements The Goals and Policies and Programs all seem acceptable as described, with the notable exception of Byway Branding as it is associated with that portion of Program emphasis on promotion/advertising/attracting visitors to the area via various media, the proposal "to more fully distribute and publicize the area". The more appropriate approach, if we wish to "enhance and protect the intrinsic qualities of this area", is to provide this plan's proposed on-site interpretation to those visitors who have found their way here. Call it a slightly more interpretive program approach than the Big Sur Coast All American Road "self-discovery" approach (as cited on p. 28 of this Plan). Eliminate the marketing aspect.

- Chapter 2. Byway Vision and Improvements This Plans discusses (p. 35) the acquisition of approximately 18 miles of former Hearst Corporation property west of State Route 1, and the authority of California State Department of Parks and Recreation to manage access and resources of this designated scenic conservation easement. Reference is made to the DPR's established "interim guidelines for the management of the property...developed with substantial public involvement". This is followed by the statement that stakeholders of the North Coast Byway "working directly with DPR... will provide valuable input in the ultimate management of the North Coast Acquisition". [italics added] Perhaps State Parks' formulated vision for protection of this scenic conservation easement, based on "substantial public involvement" as it was, should not be characterized as (and apparently dismissed as) "interim".

- Although the photographs throughout this document are great testimony to the scenic value of Route 1, the charming photograph of San Simeon Pier on page 10 is an inappropriate choice. The pier is located at San Simeon Bay, where the landholders are the Hearst Corporation and California State Parks. San Simeon Acres, the "corridor community" described in conjunction with this photograph, lies several miles to the south of San Simeon Bay. The use of this image is misleading, and is the sort of "information" (read "misinformation") we shouldn't be providing anyone depending on this document for accuracy.

- It would have been useful to be able to view the purported Appendix xxx referenced in the text, but nowhere to be found. 
Edits:

- Page 1 "Winding through San Luis Obispo County...lays lies a section of State Route 1 ..."

- Page 10 "The landscaping and the fencing on the Cal Trans median easement needs improvements..." There is no "median" in State Route 1 as it passes through San Simeon Acres.

- Page 13 "The tTraveling from the City of San Luis Obispo north through the corridor, travelers will view the following features that add to the area's visual appeal."

- Page 13 "The Morros" You have opted to confine you listing of the Morros to the "Seven Sisters" (rather than the "Nine"). Then you list eight. Which one doesn't belong, of "Cerro San Luis, Bishop's Peak, Chumash Peak, Cerro Romualdo, Hollister Peak, Cerro Cabrillo, Black Hill, and Morro Rock"?

- Page 18 "The unusual multi-trunked pygmy oak (Quercus agrifolia)...the Morro manzanita (Arctostaphylos morroensis)...Sulcaria isidiifera..." Proper species name notation.

- Page 21 "The introduction of the trail made the area accessible to a far wider group of people."

- Page 21 “...poison oak (Rhus $\mathrm{T}$ toxicodendron)..."

- Page 31 "Determine the specific location of the kiosk or wayside panel on in order to maximize the indented intended purpose..."

- Page 31 "Investing in smart technologies such as QR codes connecting to a website and/or a mobile application can to reduce visual clutter."

The following comments/recommendations, approved by the NCAC, supersede a letter to the ByWays Committee from Claudia Harmon Worthen:

1. Page 28, Caution must be taken when significantly increasing the amount of tourists that will inevitably jeopardize the delicate balance of natural resources, especially water and ESHA (Environmentally Sensitive Habitat). All of Cambria, parts of San Simeon and the coast north are in designated ESHA.

2. Building kiosks, paved turnouts and paved trails destroy the very thing that tourists are attracted to. Leave the Scenic Corridor as pristine as possible, Self-Discovery.

3. The residents need to be informed of all the advertising and promotion.

4. Cambria has single access road through town. Care must be taken to avoid traffic gridlock.

5. Your predictions for maintenance of all the improvements seems underestimated.

6. If tourism is doubled year-round, funds for the cleaning and repair of roads, highways and pathways must be budgeted.

7. Page 28, The signage: "Colorful, vibrant and pleasant", is not in keeping with the peaceful and tranquil atmosphere you want to promote. Colorful and Vibrant indicates: parties, high energy, loud music, and fast cars. As with any branding or logo, the artwork must evoke the 
desired feeling. View corridors, natural resources and promotional interpretation does not appear to be compatible.

8. Page 29, There are nearly an unlimited number of different signs to be used. While the Scenic Highway designation calls for the elimination of billboards, it is not prudent to replace them with promotional signage for retail businesses. Resident input needs to be considered. 9. Page 29, Bulletin boards, posters, banners and other advertisements are contrary to the Scenic Highway designation and, in some cases, violate the county signage codes.

10. Page 50, Language needs to be clarified. A community may be able to opt-out of the scenic byway designation, but not opt-out of the State Scenic Highway designation. That designation must be contiguous. If a community opt-outs, is the logo and signage removed? However, this may be an opportunity for a community to chose to be a Self-Discovery Area, without all the signage.

11. Eliminate the use of hard surfaces as they promote runoff and pollution. Replace with permeable pavers and compacted gravel for ADA and esthetics.

11. Hard surfaces adjacent to the ocean and waterways are highly polluting. Additional turnouts and hardscape will harm the environment that eco-tourist desires to observe.

12. Page 28 (two times) The term, Barrier Free, is no longer used. The correct term is, Universal Design or ADA. Because the access is public spaces, the correct term is ADA. 13. You list walking on the beaches and other eco-tourism as tourist draws, but the goal appears to promote consumerism, motel bookings and eating out.

14. How do you plan on, Enhancing the tourism industry's image with local residents? An informal survey of residents not involved in retail businesses do not benefit from tourism. The residents of our communities for out number the retail business people. Consideration of the residents needs to be in the forefront of the Scenic Byways document.

15. The document would benefit from the scrutiny of environmental specialists before submission to SLOCOG and finalized.

16. Enhancing the Scenic Highway should include the beautification of the views including conformance with county and city signage regulations.

17. Up lighting, flood lights, tall flags and other distractions need to be removed or mitigated for esthetics and safety.

18. Monument, gateway and interpretive signs should be made of natural materials, blend with the environment and be constructed without interior lighting.

19. Consider a pullout for Zebra viewing or ask Hearst Ranch to keep Zebras out of eyesight.

20. "Self-discovery" of the Big Sur Coast and SLO North Coast Byways has long been the approach to visitor experiences of the corridors' intrinsic qualities.

21. Page 26, number 2. Include the word softscape, the correct term for trees, flowers, bushes. Hardscape is the term for hard surfaces, like sidewalks, planters and streets.

22. Page 26, number 3. If three logos are to be used, keep them small to reduce visual clutter. 23. Additional traffic brings pollution, trash and wear and tear on the environment. Care must be taken to limit access to some areas.

Thank you for considering our recommendations and changes.

North Coast Advisory Council

Claudia Harmon Worthen, Chairperson

Laurel Stewart, Land Use Committee Chairperson 